

\title{
THE ENERGY SECTOR AND ENERGY POLICY OF THE CZECH REPUBLIC
}

\author{
Tomáš Vlček - Filip Černoch
}

Masaryk University

Brno 2013 

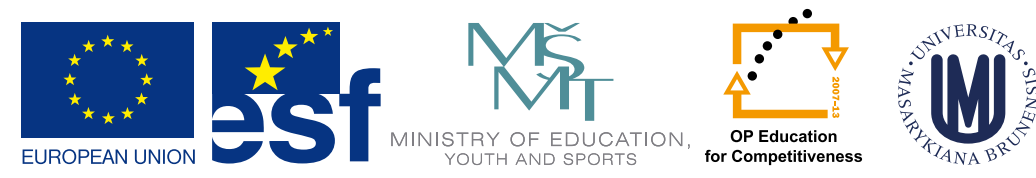

INVESTMENTS IN EDUCATION DEVELOPMENT

The text was prepared with European Social Fund (ESF) support within the project of The Education for Competitiveness Operational Programme (ECOP) under the jurisdiction of the Ministry of Education, Youth and Sports of the CR (MEYS) "Innovation of lecturing at FSS - the Department of International Relations and European Studies" (CZ 1.07/2.2.00/15.0221).

The text was prepared within the specific research project of the Department of International Relations and European Studies "Current Issues of European and International Politics" (MUNI/A/0754/2012).

Scientific Board of Masaryk University:

prof. PhDr. Ladislav Rabušic, CSc.

prof. RNDr. Zuzana Došlá, DSc.

Ing. Radmila Droběnová, Ph.D.

Mgr. Michaela Hanousková

doc. PhDr. Jana Chamonikolasová, Ph.D.

doc. JUDr. Josef Kotásek, Ph.D.

Mgr. et Mgr. Oldřich Krpec, Ph.D.

prof. PhDr. Petr Macek, CSc.

PhDr. Alena Mizerová

doc. Ing. Petr Pirožek, Ph.D.

doc. RNDr. Lubomír Popelínský, Ph.D.

Mgr. David Povolný

Mgr. Kateřina Sedláčková, Ph.D.

prof. MUDr. Anna Vašků, CSc.

prof. PhDr. Marie Vítková, CSc.

Mgr. Iva Zlatušková

doc. Mgr. Martin Zvonař, Ph.D.

Pre-publication review:

Doc. Ing. Václav Dostál, Sc.D.

(c) 2013 Tomáš Vlček, Filip Černoch

(c) 2013 Masarykova univerzita

ISBN 978-80-210-6523-9

DOI: 10.5817/CZ.MUNI.M210-6523-2013 


\section{Table of Contents}

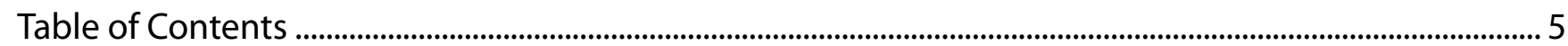

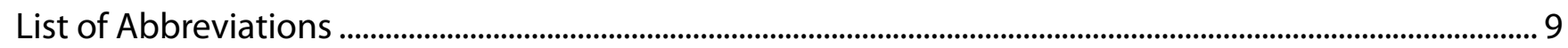

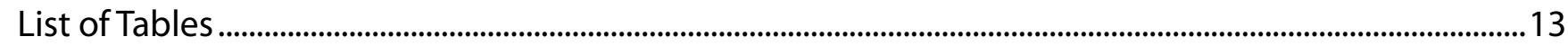

The Ownership Structure of the Most Important Entities of the Czech Energy Sector ...............................15

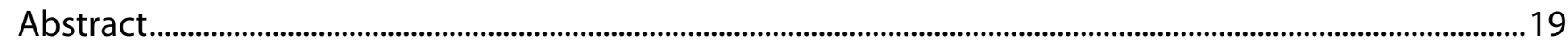

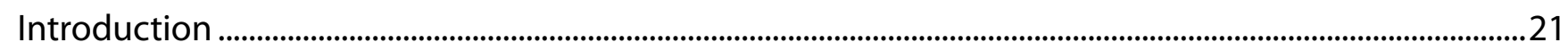

Chapter 1: Actors in, and the Legislative Framework of, the Czech Energy Sector .......................................25

1.1 State Institutions...............................................................................................................................................2

1.1.1 The Prime Minister ....................................................................................................................................2

1.1.2 The Ministry of Industry and Trade .........................................................................................................2

1.1.3 The Ministry of the Environment ...................................................................................................................2

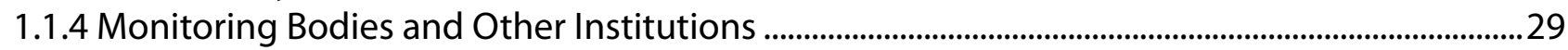

1.2 The Legislative Framework of the Energy and Raw Materials Policy of the Czech Republic .............30

1.2.1 2000 State Energy Concept........................................................................................................................31

1.2.2 Strategic Documents in the New Millennium ...........................................................................................33

1.2.3 The Most Recent Developments Concerning the Strategic Documents..........................................36

1.2.4 Conclusion .............................................................................................................................................................

Chapter 2: The History of the Czech Energy Sector ...............................................................................................39

2.1 The Thee Periods of Development from 1989 to Today .................................................................................39

2.2 The Phase of Restructuring .....................................................................................................................................40

2.3 The Phase of Privatisation .......................................................................................................................................42

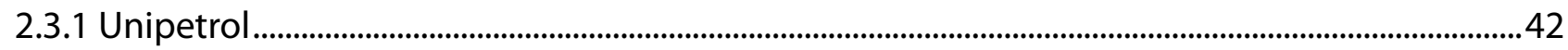

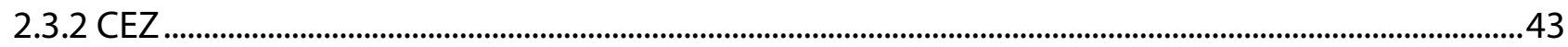

2.3.3 Transgas ...............................................................................................................................................4

2.3.4 Privatization of the Coal Sector .............................................................................................................45

2.3.5 Issues Related to Admission to the EU - Liberalization of the Energy Sector ..............................49

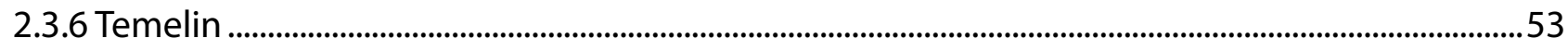

2.4 The Third Phase of Development - EU Membership Through to the Present...........................................60

Chapter 3: The Coal Sector ......................................................................................................................................65

3.1 Introduction to the Coal Industry...................................................................................................................65

3.2 Deposits, Mine Production, Companies and Traders ...................................................................................66

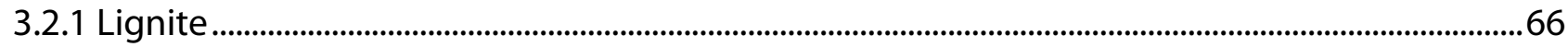

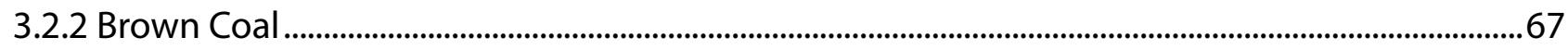

3.2.3 Bituminous Coal ..............................................................................................................................................69

3.2.4 Exploitation of Coal and Trading..................................................................................................71

3.3 The Regulatory Framework of the Coal Industry ............................................................................................72

3.4 Demand Forecast ............................................................................................................................................74

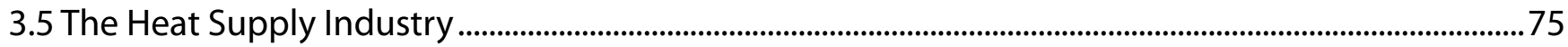

3.6 The Issue of Extraction Limits.............................................................................................................................. 81

3.6 Coal War .................................................................................................................................................................. 


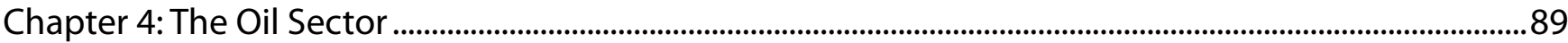

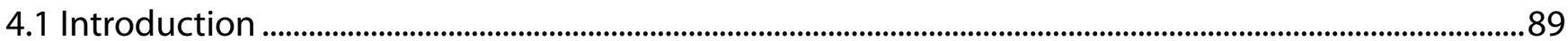

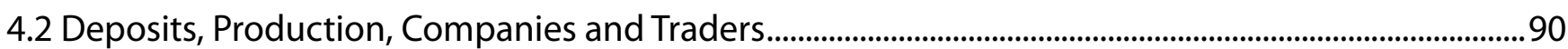

4.2.1 Deposits and the Production of Oil in the Czech Republic ...........................................................90

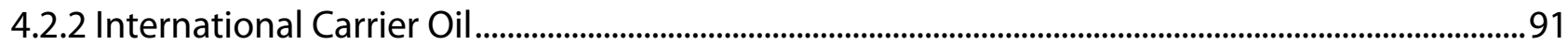

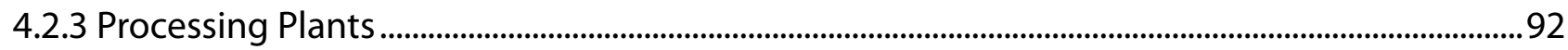

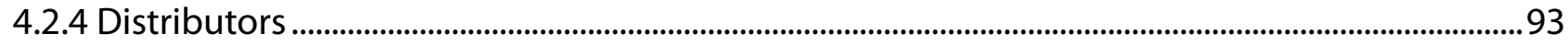

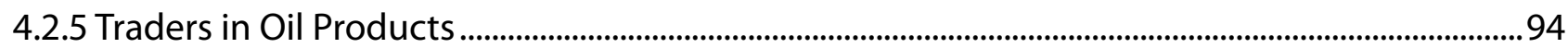

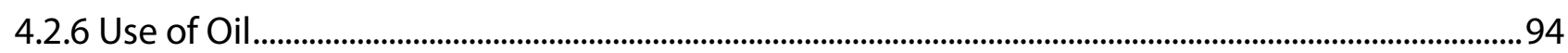

4.3 The Regulatory Framework of the Oil Industry ........................................................................................96

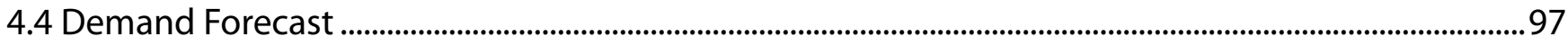

4.5 Current Issues and Proposed Projects in the Czech Oil Sector …….......................................................99

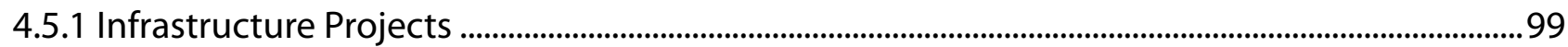

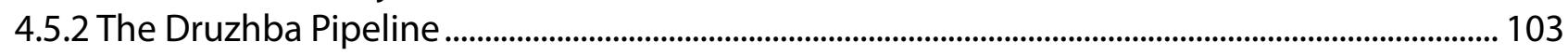

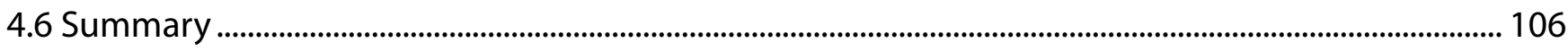

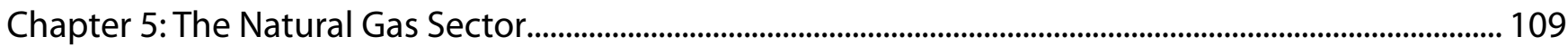

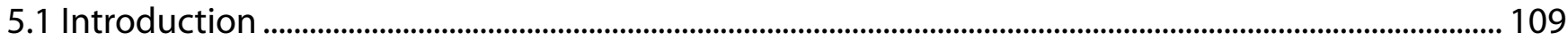

5.2 Deposits, Mine Production, Companies and Traders ................................................................................... 110

5.2.1 Deposits and the Production of Oil in the Czech Republic................................................................... 110

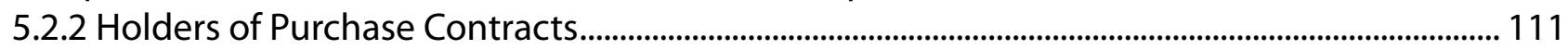

5.2.3 The Transportation, Transit and Distribution of Natural Gas......................................................... 112

5.2.4 Important Actors and Natural Gas Traders................................................................................... 115

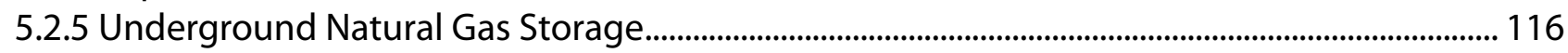

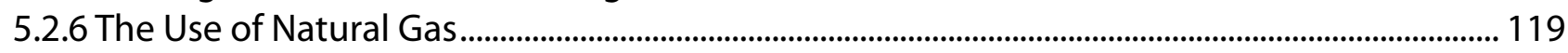

5.3 The Regulatory Framework of the Natural Gas Industry ...................................................................... 121

5.4 Demand Forecast .................................................................................................................................................... 123

5.5 The Current Issues and Projects in the Czech Gasworks Industry .......................................................... 124

5.5.1 The development of the Transmission System and of Cross-Border Interconnectors.................. 124

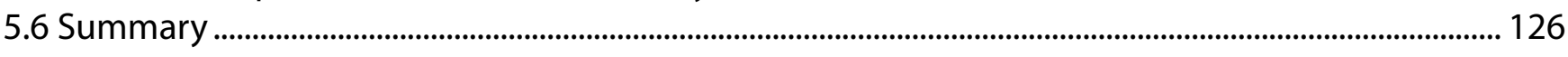

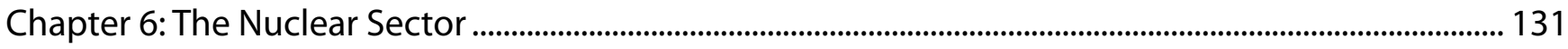

6.1 Nuclear Power Plants in the Czech Republic ............................................................................................ 131

6.2 Deposits, Mine Production, Companies and Traders ........................................................................ 132

6.3 Spent Fuel and the Nuclear Waste Repository................................................................................................. 135

6.4 The Regulatory and Safety Framework of the Nuclear Industry ............................................................. 138

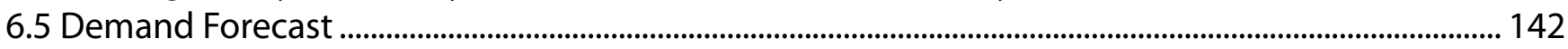

6.6 Completion of the Temelin Nuclear Power Plant ................................................................................. 145

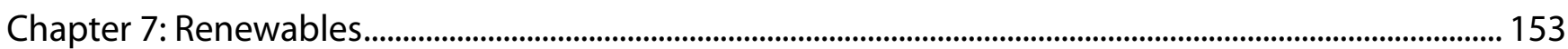

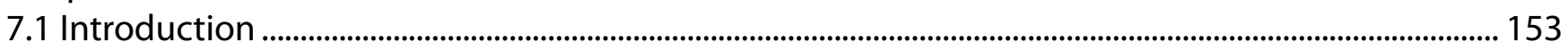

7.2 Renewables Use for Electricity and Heat Generation......................................................................... 154

7.3 The Regulatory and Safety Framework of the Renewables Industry.................................................... 159

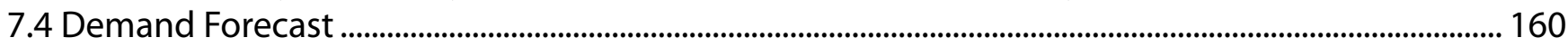

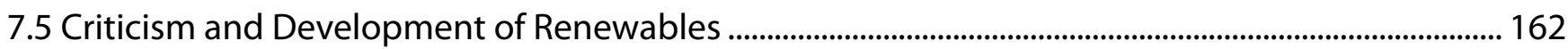


Chapter 8: The Electric Power Industry............................................................................................................... 169

8.1 The Electricity Grid of the Czech Republic ................................................................................................. 169

8.2 The Regulatory and Safety Framework of the Electric Power Industry.................................................. 172

8.2.1 State Regulatory Framework ........................................................................................................................... 172

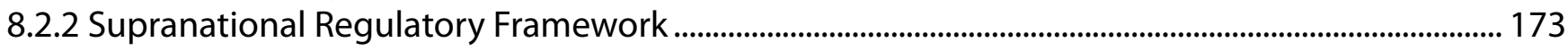

8.3 The Transmission and Regulation of Electricity ......................................................................................... 176

8.4 The Price of Electricity and the Trade in Electricity................................................................................ 179

8.5 The Stability and Development of the Transmission System - Current Issues..................................... 182

8.6 Crisis or a Revolutionary Change in the Electric Power Industry .............................................................. 186

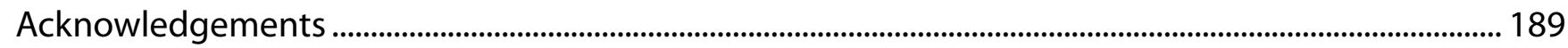

About the Authors ………………………………………………………………………………………………... 190

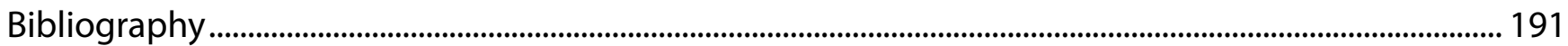

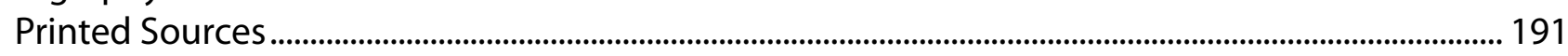

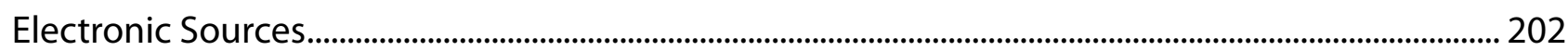

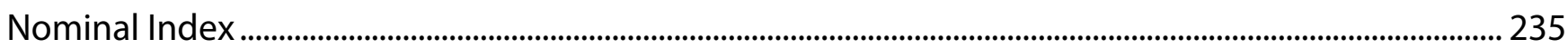





\section{List of Abbreviations}

\begin{tabular}{|c|c|}
\hline ACER & European Agency for the Cooperation of Energy Regulators \\
\hline $\mathrm{AE}$ & Alternative Power Plant (Czech: Alternativní elektrárna) \\
\hline AK ČR & Agrarian Chamber of the Czech Republic (Czech: Agrární komora České republiky) \\
\hline AVČR & Academy of Sciences of the Czech Republic (Czech: Akademie věd České republiky) \\
\hline $\mathrm{bcm}$ & A billion cubic metres \\
\hline $\mathrm{bcm} / \mathrm{y}$ & A billion cubic metres per year \\
\hline BPS & Biogas Station (Czech: Bioplynová stanice) \\
\hline BSD & Security Standard of Supplies (Czech: Bezpečnostní standard dodávky) \\
\hline BWR & Boiling Water Reactor \\
\hline CCS & Carbon Capture Storage \\
\hline CECSO & European Committee on Solid Fuels \\
\hline CENTREL & Cooperative Body of Electricity Transmission Systems Operators, Members of the Visegrad Group \\
\hline CNG & Compressed Natural Gas \\
\hline CTR & Central Crude Oil Tank (Czech: Centrální tankoviště ropy) \\
\hline CZT & Central Heating Supply (Czech: Centrální/centralizované zásobování teplem) \\
\hline ČBÚ & Czech Mining Authority (Czech: Český báňský úřad) \\
\hline ČGS & Czech Geological Survey (Czech: Česká geologická služba) \\
\hline ČNR & Czech National Council (Czech: Česká národní rada) \\
\hline ČPU & Czech Gas Union (Czech: Česká plynárenská unie) \\
\hline ČPS & Czech Gas Association (Czech: Česká plynárenský svaz) \\
\hline ČR & The Czech Republic (Czech: Česká republika) \\
\hline ČSA & Czechoslovak Army (Czech: Československá armáda) \\
\hline ČSM & Czechoslovak Union of Youth (Czech: Československý svaz mládeže) \\
\hline ČSSD & Czech Social Democratic Party (Czech: Česká Strana Sociálně Demokratická) \\
\hline ČSSR & The Czechoslovak Socialist Republic (Czech: Československá socialistická republika) \\
\hline ČUE & Bituminous energy coal (Czech: Černé uhlí energetické) \\
\hline ČÚBP & Czech Authority for Safety at Work \\
\hline DME & Dimethylether \\
\hline DN & Diameter Nominal \\
\hline DPH & Value Added Tax (Czech: Daň z přidané hodnoty) \\
\hline DS & Distribution System \\
\hline DT PpS & Day-Ahead Ancillary Services Market (Czech: Denní trh s podpůrnými službami) \\
\hline DZT & Decentralized Heating Supply (Czech: Decentralizované zásobování teplem) \\
\hline EBRD & European Bank for Reconstruction and Development \\
\hline EC & European Commission \\
\hline EDU & Dukovany Power Plant (Czech: Elektrárna Dukovany) \\
\hline EEPR & European Energy Program for Recovery \\
\hline ENSREG & European Nuclear Safety Regulators Group \\
\hline ENTSO-E & European Network of Transmission System Operators for Electricity \\
\hline $\mathrm{EPH}$ & Energy and Industry Holding, plc (Czech: Energetický a průmyslový holding, a. s.) \\
\hline $\mathrm{EPR}^{\mathrm{TM}}$ & European Pressurized Reactor ${ }^{\mathrm{TM}}$ \\
\hline EPRU & Prunerov Power Plant (Czech: Elektrárna Prunéřov) \\
\hline ERÚ & Energy Regulatory Office (Czech: Energetický regulační úřad) \\
\hline
\end{tabular}




\begin{tabular}{|c|c|}
\hline ES & Electricity Supply System (Czech: Elektrizační soustava) \\
\hline ES & European Community \\
\hline ETBE & Ethyl Tert-Butyl Ether \\
\hline ETE & Temelin Power Plant (Czech: Elektrárna Temelín) \\
\hline ETI & Tisova Power Plant (Czech: Elektrárna Tisová) \\
\hline ETS & Emission Trading Scheme \\
\hline ETU & Tusimice Power Plant (Czech: Elektrárna Tušimice) \\
\hline EU & European Union \\
\hline EURACOAL & European Association for Coal and Lignite \\
\hline EURATOM & European Atomic Energy Community \\
\hline FAME & Fatty Acid Methyl Esters \\
\hline FVE & Photovoltaic Power Plant (Czech: Fotovoltaická elektrárna) \\
\hline GOE & Geothermal Power Plant (Czech: Geotermální elektrárna) \\
\hline HDP & Gross Domestic Product (Czech: Hrubý domácí produkt) \\
\hline HÚRAO & Deep Geological Radioactive Waste Depositary (Czech: Hlubinné úložiště radioaktivních odpadů) \\
\hline $\mathrm{HU}$ & Brown Coal (Czech: Hnědé uhlí) \\
\hline CHKO & Landscape Protected Area (Czech: Chráněná krajinná oblast) \\
\hline IAEA & International Agency for Atomic Energy \\
\hline IEA & International Energy Agency \\
\hline $\mathrm{IKL}$ & Ingolstadt - Kralupy - Litvínov \\
\hline ISO & Independent System Operator \\
\hline JE & Nuclear Power Plant (Czech: Jaderná elektrárna) \\
\hline k.p. & Business Concern (Czech: Koncernový podnik) \\
\hline KDU-ČSL & $\begin{array}{l}\text { Christian and Democratic Union - Czechoslovak People's Party (Czech: Křest’anská a demokratická unie } \\
\text { - Československá strana lidová) }\end{array}$ \\
\hline KSČM & Communist Party of Bohemia and Moravia (Czech: Komunistická strana Čech a Moravy) \\
\hline LBL & Lanzhot - Baumgarten Line \\
\hline LDS & Local Distribution System \\
\hline LNG & Liquefied Natural Gas \\
\hline LPG & Liquefied Petroleum Gas \\
\hline LTO & Light Fuel Oil (Czech: Lehký topný olej) \\
\hline LULUCF & Land Use, Land-Use Change and Forestry \\
\hline MAVIR & $\begin{array}{l}\text { Hungarian Transmission System Operator (Hungarian: Magyar Villamosenergia-ipari Átviteli Rendszer- } \\
\text { irányító Zártkörúen Működő Részvénytársaság) }\end{array}$ \\
\hline MIR & Modernized International Reactor \\
\hline MN & Extra Low Voltage (Czech: Malé napětí) \\
\hline MO & Low Energy Users (Czech: Maloodběratelé) \\
\hline MOO & Business Low Energy Users (Czech: Maloodběratelé podnikatelé) \\
\hline MOP & Household Low Energy Users (Czech: Maloodběratelé obyvatelstvo) \\
\hline MPO & Ministry of Industry and Trade (Czech: Ministerstvo průmyslu a obchodu) \\
\hline MTBE & Methyl Tert-butyl Ether \\
\hline MUS & Most Coal Company (Czech: Mostecká uhelná společnost) \\
\hline MVE & Small Hydro Power Plants (Czech: Malé vodní elektrárny) \\
\hline $\mathrm{MWd} / \mathrm{kg}$ & Megawatt-Day Per Kilogram, (a unit for energy released by nuclear fuel) \\
\hline MWe & A unit of electrical power \\
\hline MWh & A unit of electrical energy \\
\hline MWt & A unit of thermal power \\
\hline MZV & Ministry of Foreign Affairs (Czech: Ministerstvo zahraničních věcí) \\
\hline
\end{tabular}




\begin{tabular}{|c|c|}
\hline MŽP & Ministry of the Environment (Czech: Ministerstvo životního prostředí) \\
\hline n.p. & National Enterprise (Czech: Národní podnik) \\
\hline NAP & National Allocation Plan, National Action Plan \\
\hline NEK & Independent Expert Commission (Czech: Nezávislá odborná komise) \\
\hline NN & Low Voltage (Czech: Nízké napětí) \\
\hline NPT & Treaty on the Non-Proliferation of Nuclear Weapons \\
\hline $\mathrm{OAO}$ & Public Joint Stock Company (Russian: Открытое Акционерное Общество) \\
\hline ODS & Civic Democratic Party (Czech: Občanská demokratická strana) \\
\hline $\mathrm{OOO}$ & Limited Liability Company (Russian: Общество с ограниченной ответственностью) \\
\hline OTE & Czech Electricity Market Operator (Czech: Operátor trhu s elektřinou, a. s.) \\
\hline OZE & Renewables \\
\hline PAK & Pątnów-Adamów-Konin \\
\hline PČR & Parliament of the Czech Republic (Czech: Parlament České republiky) \\
\hline $\mathrm{PE}$ & Steam Power Plant (Czech: Parní elektrárna) \\
\hline PGNiG & Polish Oil and Gas Company \\
\hline PHM & Propellants (Czech: Pohonné hmoty) \\
\hline PHL & Propellant Fuels (Czech: Pohonné látky) \\
\hline PPE & Combined Cycle Power Plant (Czech: Paroplynová elektrárna) \\
\hline PPP & Purchasing Power Parity \\
\hline PpS & Ancillary Services (Czech: Podpůrné služby) \\
\hline PS & Electric Power Transmission (Czech: Přenosová soustava) \\
\hline PSE & Gas and Combustion Power Plant (Czech: Plynová a spalovací elektrárna) \\
\hline PVE & Pumped-Storage Hydropower Plant (Czech: Přečerpávací vodní elektrárna) \\
\hline PWR & Pressurized Water Reactor \\
\hline PXE & Power Exchange Central Europe, a. s. \\
\hline PZP & Underground Gas Storage Reservoir (Czech: Podzemní zásobník plynu) \\
\hline QS10 & Quick Start 10 Minute Reserve \\
\hline RDS & Regional Distribution System \\
\hline REAS & Regional Energy Distribution Companies (Czech: Regionální energetické distribuční společnosti \\
\hline RPDS & Regional Distribution System Operator (Czech: Regionální provozovatel distribuční soustavy) \\
\hline COMECON & Council of Mutual Economic Assistance (Czech: Rada vzájemné hospodářské pomoci) \\
\hline RZ15 & Regulation Reserve Available within 15 minutes \\
\hline RZ30+ & Positive Minute Reserve Available within 30 Minutes \\
\hline RZ30- & Negative Minute Reserve Available within 30 Minutes \\
\hline RZN30+ & Positive (Non-Rotary) Minute Reserve Available within 30 Minutes \\
\hline RZN30- & Negative (Non-Rotary) Minute Reserve Available within 30 Minutes \\
\hline RZPR & Primary Regulation Reserve \\
\hline RZSR & Secondary Regulation Reserve \\
\hline RZTR+ & Tertiary Positive Regulation Reserve \\
\hline RZTR- & Tertiary Negative Regulation Reserve \\
\hline RZV & Regulation Reserve Seconds (Czech: Regulační záloha vteřinová) \\
\hline S.p. & State Enterprise (Czech: Státní podnik) \\
\hline SBS & State Mining Authority (Czech: Státní báňská správa) \\
\hline SCZT & Central Heating Supply System (Czech: Soustava centrálního/centralizovaného zásobování teplem) \\
\hline SEI & State Energy Inspection (Czech: Státní energetická inspekce) \\
\hline SEK & State Energy Concept (Czech: Státní energetická koncepce) \\
\hline SEP & State Energy Policy (Czech: Státní energetická politika) \\
\hline SEPS & Slovak Electricity Transmission System, plc (Slovakian: Slovenská elektrizačná prenosová sústava, a. s.) \\
\hline
\end{tabular}




\begin{tabular}{|c|c|}
\hline SKO & Mixed Municipal Waste (Czech: Směsný komunální odpad) \\
\hline SLE & Solar Power Plant (Czech: Solární elektrárna) \\
\hline SNSA & Slovenian Nuclear Safety Administration \\
\hline SPOT & Single Payment Options Trading \\
\hline SSHR & Administration of State Material Reserves (Czech: Správa státních hmotných rezerv) \\
\hline USSR & The Union of Soviet Socialist Republics (Czech: Svaz sovětských socialistických republik) \\
\hline SÚJB & State Office for Nuclear Safety (Czech: Státní úřad pro jadernou bezpečnost) \\
\hline SÚJCHBO & $\begin{array}{l}\text { National Institute for Nuclear, Chemical and Biological Protection (Czech: Státní ústav jaderné, chem- } \\
\text { ické a biologické ochrany, v. v. i.) }\end{array}$ \\
\hline SÚRAO & Administration of Radioactive Waste Repository (Czech: Správa úložišt' radioaktivních odpadů) \\
\hline SÚRO & National Radiation Protection Institute (Czech: Státní ústav radiační ochrany, v. v. i.) \\
\hline$S Z$ & Green Party (Czech: Strana zelených) \\
\hline TAL & Transalpine Pipeline \\
\hline TOEL & Extra-Light Fuel Oil (Czech: Topný olej extralehký) \\
\hline TPA & Third Party Access \\
\hline TPES & Total Primary Energy Supply \\
\hline TSO & Transmission System Operator \\
\hline TUV & Warm Utility Water (Czech: Teplá užitková voda) \\
\hline UCTE & Union for the Coordination of the Transmission of Electricity \\
\hline UN & United Nations \\
\hline UNFCCC & United Nations Framework Convention on Climate Change \\
\hline USD & United States Dollar \\
\hline UVN & Ultra-High Voltage (Czech: Ultra vysoké napětí) \\
\hline ÚNMZ & $\begin{array}{l}\text { Office for Standards, Metrology and Testing (Czech: Úřad pro technickou normalizaci, metrologii a státní } \\
\text { zkušebnictví) }\end{array}$ \\
\hline ÚOHS & Office for the Protection of Competition (Czech: Úřad pro ochranu hospodářské soutěže) \\
\hline ÚRAO & Radioactive Waste Repository (Czech: Úložiště radioaktivních odpadů) \\
\hline VE & Hydropower Plant (Czech:Vodní elektrárna) \\
\hline VTE & Wind Power Plant (Czech: Větrná elektrárna) \\
\hline VÚHU & Brown Coal Research Institute, plc (Czech: Výzkumný ústav pro hnědé uhlí, a. s.) \\
\hline VV & Public Affairs (Czech: Věci veřejné) \\
\hline VN & High Voltage (Czech:Vysoké napětí) \\
\hline VO & Large Energy Users (Czech:Velkoodběratelé) \\
\hline VVN & Very High Voltage (Czech:Velmi vysoké napětí) \\
\hline VVER & Water-Water Energy Reactor (Czech: Vodo-Vodní energetický reactor) \\
\hline ZSDNP & $\begin{array}{l}\text { Czech Employers' Association of Mining and Oil Industries (Czech: Zaměstnavatelský svaz důlního a naf- } \\
\text { tového průmysl Společenstvo těžařu ČR }\end{array}$ \\
\hline ZVN & Extra High Voltage (Czech: Zvláště vysoké napětí) \\
\hline
\end{tabular}




\section{List of Tables}

Tab. 2.1: The Process of Electricity Market Liberalization ................................................................................. 50

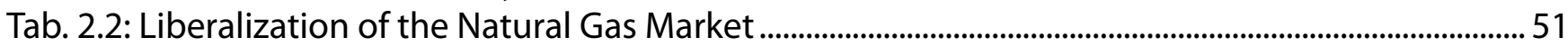

Tab. 2.3: The Number of Electricity and Natural Gas Suppliers Changed During the Liberalization Process and After its Completion ...............................................................................52

Tab. 2.4: The Final Report of the Expert Team for an Independent Assessment of the Completion of the Temelin Nuclear Power Plant ....................................................................... 54

Tab. 2.5: The Increasing Costs of Building the Temelin Nuclear Power Plant in 1993-1999 (billion CZK)

Tab. 2.6: The Production and Export of Electricity in the Czech Republic

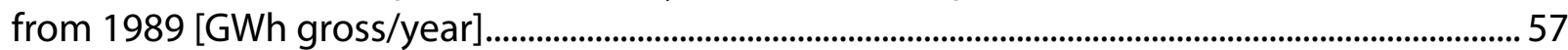

Tab. 2.7: CEZ Coal-Fired Power Plants - decommissioned capacity (reduction program of coal) ..................58

Tab. 2.8: Electricity Consmuption 1993-2012 ...............................................................................................60

Tab. 3.1: Coal Power Plants in the Czech Republic with more than 150 MWe of Installed Capacity..............66

Tab. 3.2: Deposits, reserves and mine production of lignite in the Czech Republic ................................... 67

Tab. 3.3: Deposits, reserves and mine production of brown coal in the Czech Republic............................68

Tab. 3.4: Exploitable Reserves of Brown Coal and Their Limits .....................................................................69 69

Tab. 3.5: Deposits, reserves and mine production of bituminous coal in the Czech Republic................. 70

Tab. 3.6: The Shares of Solid, Liquid and Gas Fuels in Energy Resource Consumption

According to the State Energy Policy of the Czech Republic from 2004

and Its Updates from February 2010 and August 2012 (in \%) ............................................................ 74

Tab. 3.7: The Balance of Thermal Energy from the Central Heating Supply System in 2000-2010........ 76

Tab. 3.8: Fuel Mix for Production of Thermal Energy in the Czech Republic in 2010 ................................. 77

Tab. 3.9: Forecast of Energy Bituminous Coal Demand .................................................................................. 79

Tab. 3.10: Forecast of Brown Coal Demand according to EGU Brno .............................................................. 80

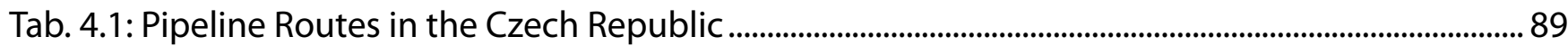

Tab. 4.2: Deposits, reserves and oil well production of oil in the Czech Republic ......................................... 90

Tab. 4.3: The Oil Pipeline Network of the Czech Republic ............................................................................91

Tab. 4.4: Oil Consumption in the Czech Republic by Sector ............................................................................. 95

Tab. 4.5: Oil Refining in the Czech Republic..................................................................................................95

Tab. 4.6: Volume of Crude Oil and Oil Products Reserves Operated by AMSR as of 12/31/2010 ............... 97

Tab. 4.7: The Shares of Solid, Liquid and Gas Fuels in Energy Resource Consumption

According to the State Energy Policy of the Czech Republic from 2004

and Its Revision from February 2010 and August 2012 (in \%) ........................................................... 97

Tab. 4.8: Oil Consumption Prediction ...................................................................................................................98

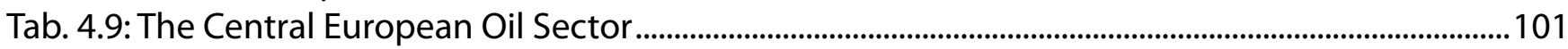

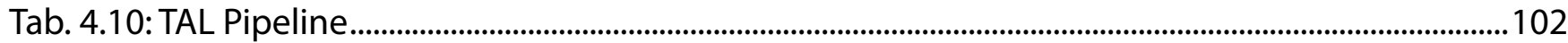

Tab. 4.11: Oil Curtailment to the Czech Republic........................................................................................104

Tab. 5.1: Natural Gas Supplies and the Most Important Companies in the Gas Sector ..............................110

Tab. 5.2: Deposits, reserves and production of natural gas in the Czech Republic ....................................111

Tab. 5.3: The Price for the Steady Daily Transportation Capacity of Natural Gas during a One-Year Contract Lasting 12 Months

Tab. 5.4: Underground Natural Gas Storage Reservoirs in the Czech Republic and their Maximum Capacity as of January 1st, 2009

Tab. 5.5: Planned Projects to Increase the Capacity of Existing Reservoirs or to Develop New Underground Gas Storage Facilities in the Czech Republic. 
Tab. 5.6: Natural Gas Consumption in the Czech Republic by Sector ....

Tab. 5.7: The Shares of Solid, Liquid and Gas Fuels in Energy Resource Consumption According to the State Energy Policy of the Czech Republic from 2004 and Its Update from February 2010 and August 2012 (in \%). 123

Tab. 5.8: Natural Gas Demand Prediction for the Czech Republic

Tab. 6.1: Review of CEZ Nuclear Power Plants as of December 31, 2012

Tab. 6.2: Deposits, reserves and mine production of uranium in the Czech Republic 133

Tab. 6.3: NYMEX Uranium Futures Price of Uranium Concentrate $\left(\mathrm{U}_{3} \mathrm{O}_{8}\right)$. .134

Tab. 6.4: Scheme of the End of the Nuclear Cycle in the Czech Republic 138

Tab. 6.5: Regulatory and Safety Organs for the Czech Nuclear Sector and Their Role 140

Tab. 6.6: The Shares of Solid, Liquid and Gas Fuels in Energy Resource Consumption According to the State Energy Policy of the Czech Republic from 2004 and Its Revisions from February 2010

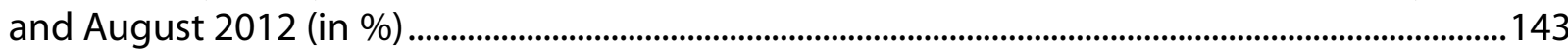

Tab. 6.7: Forecast of Uranium Concentrate Production in the Czech Republic (tonnes per year) ............... 144 Tab. 6.8: Forecast of Uranium Concentrate Demand in the Czech Republic (tonnes per year) ............. 144 Tab. 6.9: Technical Characteristics of the Projects Proposed by Single Nuclear Tender Applicants ............ 146 Tab. 6.10: Comparison of Some Economic and Environmental Advantages and Disadvantages of Nuclear and Thermal Power Plants

Tab. 7.1: The Amount of Solar Energy in the Czech Republic which Strikes a Square Metre of Surface

Bent at an Angle of $40^{\circ}$ Southwards (Wh/ $\mathrm{m}^{2} /$ day).

Tab. 7.2: Biomass Combustion Facilities in the Czech Republic in 2011

Tab. 7.3: Obligations Resulting from Membership in International Organizations 160

Tab. 7.4: Scenario of Renewable Energy Share in Final Energy Consumption According to the National Renewable Energy Action Plan of the Czech Republic.

Tab. 7.5: The Shares of Solid, Liquid and Gas Fuels in Energy Resource Consumption According to the State Energy Policy of the Czech Republic from 2004 and Its Revisions from February 2010 and August 2012 (in \%)

Tab. 7.6: Expected Development of Electricity and Heat Production from Renewables by 2030 ..............161

Tab. 7.7: Gross Production of Electricity from Renewables (TWh) ..............................................................162

Tab. 7.8: Installed Capacity of Photovoltaic Power Plants in the Czech Electrification System...................163

Tab. 7.9: Total Expenditures for Photovoltaic and Wind Power Plants in the Czech Electrification

System in the Period $2010-2030$

Tab. 7.10: A Showcase of Capital Expenditure for Science and Research Promotion across Various

Energy Sectors

Tab. 8.1: Installed Capacity in the Czech Electricity Grid on December, 31 2012 2.....................................169

Tab. 8.2: Gross Electricity Production in 2012 ............................................................................................170

Tab. 8.3: Regulatory Organs in the Electric Power Sector and Their Role..................................................172

Tab. 8.4: The Process of Electricity Market Liberalisation in the Czech Republic.........................................174

Tab. 8.5: A Total of Consumption and Connection Sites which Have Changed Supplier .........................176

Tab. 8.6: A Simplified Division of Regulation Reserves as part of CEPS System Services .........................178

Tab. 8.7: Maximum Regulation Reserves in the Czech Republic in 2013 ....................................................179

Tab. 8.8: Share of Single Components of the Price of Electricity Supplies to Households in 2010

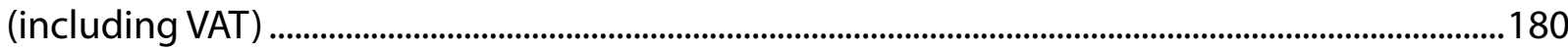

Tab. 8.9: Minimum and Maximum Volume Orders at PXE Exchange .........................................................181

Tab. 8.10: The Example of the Construction Process of an Extra High Voltage Line................................... 183

Tab. 8.11: Comparison of Different Types of Power Plant .............................................................................184

Tab. 8.12: Forecast of the Future Course of Electricity Consumption in the Czech Republic (GWh)............ 187

Tab. 8.13: The Potential Construction of New Electricity Sources ....................................................................188 


\section{The Ownership Structure of the Most Important Entities of the Czech Energy Sector}

As of January 1, 2011.

\begin{tabular}{|c|c|c|c|c|c|c|}
\hline Entity & Owner & $\%$ & Owner & $\%$ & Owner & $\%$ \\
\hline Alpiq Generation (CZ), s. r. o. & Alpiq Ltd. & 100 & - & - & - & - \\
\hline APB-PLZEN, a. s. & Petr Brezina & 100 & - & - & - & - \\
\hline ArcelorMittal Ostrava, a. s. & $\begin{array}{l}\text { ArcelorMittal } \\
\text { Holdings AG }\end{array}$ & 100 & - & - & - & - \\
\hline BENZINA, s. r. o. & Unipetrol, a. s. & 100 & - & - & - & - \\
\hline Bicorn, s. r. o. & $\begin{array}{l}\text { RIGHT POWER SK, } \\
\text { s.r. o. }\end{array}$ & 100 & - & - & - & - \\
\hline Bohemia Energy Entity, s. r. o. & Hana Pisarikova & 50 & $\begin{array}{c}\text { MR } \\
\text { COMMUNICATIONS, s. } \\
\text { r. o. (Milan Ruzicka ) }\end{array}$ & 50 & - & - \\
\hline Burza cennych papiru Praha, a.s. & $\begin{array}{c}\text { CEESEG } \\
\text { Aktiengesellschaft }\end{array}$ & 92,739 & GE Money Bank, a. s. & 6,556 & $\begin{array}{c}\text { Other } \\
\text { shareholders }\end{array}$ & 0,705 \\
\hline BXR Green B.V. & Zdenek Bakala & 50 & Other shareholders & 50 & - & - \\
\hline BXR Mining B.V. & $\begin{array}{l}\text { RPG Partners } \\
\text { Limited }\end{array}$ & $?$ & $\begin{array}{l}\text { Bakala Crossroads } \\
\text { Group Limited }\end{array}$ & $?$ & - & - \\
\hline Carbounion Bohemia, spol. s r. o. & Petr Paukner & 100 & - & - & - & - \\
\hline Centropol Energy, a. s. & $\begin{array}{l}\text { Centropol Holding, } \\
\text { a.s. }\end{array}$ & 100 & - & - & - & - \\
\hline Centropol Holding, a. s. & Ales Graf & 100 & - & - & - & - \\
\hline Conte, spol. s r. o. & Jiri Jise & 100 & - & - & - & - \\
\hline CEPRO, a. s. & $\begin{array}{l}\text { Ministry of Finance } \\
\text { of the Czech } \\
\text { Republic }\end{array}$ & 100 & - & - & - & - \\
\hline CEPS, a. s. & $\begin{array}{l}\text { Ministry of Industry } \\
\text { and Trade of the } \\
\text { Czech Republic }\end{array}$ & 85 & $\begin{array}{l}\text { Ministry of Labour } \\
\text { and Social Affairs of } \\
\text { the Czech Republic }\end{array}$ & 15 & - & - \\
\hline Ceská energie, a. s. & CE GROUP & 100 & - & - & - & - \\
\hline Ceska naftarska společnost, s. r. o. & $\begin{array}{c}\text { LAMA } \\
\text { INVESTMENTS, a. s. }\end{array}$ & 100 & - & - & - & - \\
\hline Ceska plynarenska, a. s. & CE GROUP & 100 & - & - & - & - \\
\hline Ceska rafinerska, a. s. & Unipetrol, a.s. & 51,22 & Eni International B.V. & 32,445 & $\begin{array}{l}\text { Shell Overseas } \\
\text { Investments B.V. }\end{array}$ & 16,335 \\
\hline Ceske Energeticke Centrum, a. s. & $\begin{array}{l}\text { EEC Europe Energy } \\
\text { Center Limited }\end{array}$ & 100 & - & - & - & - \\
\hline Ceské plynovody, a. s. & $\begin{array}{c}\text { Gas Storage Ceska } \\
\text { plynarenska } \\
\text { (GSCeP), a.s. } \\
\end{array}$ & 100 & - & - & - & - \\
\hline CEZ, a.s. & $\begin{array}{c}\text { The Ministry of } \\
\text { Finance of the Czech } \\
\text { Republic }\end{array}$ & 70,31 & $\begin{array}{l}\text { Other legal entities } \\
\text { and private persons }\end{array}$ & 29,69 & - & - \\
\hline Czech Energy Holding, a. s. & EP Energy, a.s. & 100 & - & - & - & - \\
\hline Dalkia Ceska republika, a. s. ${ }^{1}$ & $\begin{array}{c}\text { Societe de } \\
\text { Participations et } \\
\text { d'Investissements } \\
\text { Diversifies 2 }\end{array}$ & 68,056 & Dalkia International & 10 & $\begin{array}{l}\text { Energeticky } \\
\text { a prumyslový } \\
\text { holding, a.s. }\end{array}$ & 10 \\
\hline DIAMO, s. p. & $\begin{array}{l}\text { Ministry of Industry } \\
\text { and Trade of the } \\
\text { Czech Republic }\end{array}$ & 100 & - & - & - & - \\
\hline $\begin{array}{l}\text { E.ON Czech Holding Verwaltungs } \\
\text { GmbH }\end{array}$ & $\begin{array}{l}\text { E.ON Czech Holding } \\
\text { AG }\end{array}$ & 99,999 & E.ON Energie AG & 0,001 & - & - \\
\hline
\end{tabular}




\begin{tabular}{|c|c|c|c|c|c|c|}
\hline Entity & Owner & $\%$ & Owner & $\%$ & Owner & $\%$ \\
\hline E.ON Ceská republika, s. r. o. & $\begin{array}{l}\text { E.ON Czech Holding } \\
\text { Verwaltungs GmbH } \\
\end{array}$ & 100 & - & - & - & - \\
\hline E.ON Energie, a. s. & $\begin{array}{l}\text { E.ON Czech Holding } \\
\text { Verwaltungs-GmbH }\end{array}$ & 100 & - & - & - & - \\
\hline E.ON Distribuce & $\begin{array}{l}\text { E.ON Czech Holding } \\
\text { Verwaltungs GmbH }\end{array}$ & 100 & - & - & - & - \\
\hline $\begin{array}{l}\text { East Bohemia Energy Holding } \\
\text { Limited }\end{array}$ & $\begin{array}{l}\text { J\&T Finance Group, } \\
\text { a. s. } \\
\end{array}$ & 100 & - & - & - & - \\
\hline Ecoenerg Windkraft GmbH \& Co. KG & $\begin{array}{c}\text { eab technology } \\
\text { GmbH (Rainer Sack) }\end{array}$ & 100 & - & - & - & - \\
\hline Elektrarny Opatovice, a. s. & $\begin{array}{l}\text { East Bohemia } \\
\text { Energy Holding } \\
\text { Limited } \\
\end{array}$ & 100 & - & - & - & - \\
\hline $\begin{array}{l}\text { Energeticky a prumyslovy holding, } \\
\text { a. s. }\end{array}$ & $\begin{array}{c}\text { PPF Group and PPF } \\
\text { Partners } \\
\end{array}$ & 40 & $\begin{array}{l}\text { J\&T Finance Group, } \\
\text { a.s. }\end{array}$ & 40 & Daniel Kretinsky & 20 \\
\hline Energie Bohemia, a. s. ${ }^{2}$ & $\begin{array}{c}\text { Verbundnetzgas } \\
\text { (VNG) Energie } \\
\text { Czech, a. s. }\end{array}$ & 100 & - & - & - & - \\
\hline ENERGO-PRO Czech, s. r. o. & Jiri Cerny & $?$ & Jiri Krusina & $?$ & Jaromir Tesar & $?$ \\
\hline Energotrans, a. s. & $\begin{array}{c}\text { Prazska teplarenska, } \\
\text { a.s. } \\
\end{array}$ & 100 & - & - & - & - \\
\hline EP Energy, a.s. & $\begin{array}{l}\text { Energeticky } \\
\text { a prumyslovy } \\
\text { holding, a. s. }\end{array}$ & 100 & - & - & - & - \\
\hline EuroOil, a.s. & CEPRO, a. S. & 100 & - & - & - & - \\
\hline Eustream, a.s. & $\begin{array}{c}\text { Slovensky } \\
\text { plynarensky } \\
\text { priemysel, a.s. }\end{array}$ & 100 & - & - & - & - \\
\hline FVE CZECH NOVUM, s. r. o. & Decci, a. s. & 63 & $\begin{array}{c}\text { Berlanga Uzbekistan } \\
\text { B.V. }\end{array}$ & 37 & - & - \\
\hline $\begin{array}{l}\text { Gas Storage Ceska plynarenska } \\
\text { (GSCeP), a. s. }\end{array}$ & $\begin{array}{l}\text { Ceska plynarenska, } \\
\text { a.s. }\end{array}$ & 100 & - & - & - & - \\
\hline Green Gas DPB, a. s. & $\begin{array}{c}\text { Green Gas } \\
\text { International B.V. }\end{array}$ & 100 & - & - & - & - \\
\hline Green Gas International B.V. & BXR Green B.V. & 75 & $\begin{array}{l}\text { Consensus Business } \\
\text { Group, Demeter } \\
\text { Partners, Standard } \\
\text { Bank Group and } \\
\text { other shareholders }\end{array}$ & 25 & - & - \\
\hline KKCG, a. s. & KKCG SE & 100 & - & - & - & - \\
\hline KKCG Oil \& Gas B.V. & KKCG SE & 100 & & & & \\
\hline KKCG SE & KKCG HOLDING LTD & 100 & - & - & - & - \\
\hline LAMA INVESTMENTS, a. s. & Petr Lamich & 51 & Company managers & 49 & - & - \\
\hline LUKOIL Czech Republic, s. r. o. & $\begin{array}{l}\text { LUKOIL Europe } \\
\text { Holdings B.V. }\end{array}$ & 99.9 & LUKOIL Holding AG & 0.1 & - & - \\
\hline Lumen Energy, a.s. & $\begin{array}{c}\text { LUMEN } \\
\text { International, a.s. }\end{array}$ & $?$ & Company managers & $?$ & - & - \\
\hline Lumius, spol. s r. o. & Pavel Miklas & 100 & - & - & - & - \\
\hline MERO CR, a. s. & $\begin{array}{c}\text { Ministry of Finance } \\
\text { of the Czech } \\
\text { Republic }\end{array}$ & 100 & - & - & - & - \\
\hline Moravske naftove doly, a. s. & KKCG Oil \& Gas B.V. & 100 & - & - & - & - \\
\hline Nafta, a.s. & $\begin{array}{c}\text { Slovensky } \\
\text { plynarensky } \\
\text { priemysel, a. s. } \\
\end{array}$ & 56.15 & $\begin{array}{c}\text { E.ON Ruhrgas } \\
\text { International AG }\end{array}$ & 40.45 & $\begin{array}{c}\text { Other } \\
\text { shareholders }\end{array}$ & 3.4 \\
\hline NET4GAS, s. r. o. & RWE Transgas, a. s. & 100 & - & - & - & - \\
\hline New World Resources N.V. & BXR Mining B.V. & 63.66 & Other shareholders & 36.34 & - & - \\
\hline
\end{tabular}




\begin{tabular}{|c|c|c|c|c|c|c|}
\hline Entity & Owner & $\%$ & Owner & $\%$ & Owner & $\%$ \\
\hline NPTH, a. s. & $\begin{array}{c}\text { East Bohemia } \\
\text { Energy Holding } \\
\text { Limited }\end{array}$ & 100 & - & - & - & - \\
\hline OKD, a. s. & $\begin{array}{c}\text { New World } \\
\text { Resources N.V. }\end{array}$ & 100 & - & - & - & - \\
\hline OKK Koksovny, a.s. & $\begin{array}{c}\text { New World } \\
\text { Resources Plc }\end{array}$ & 100 & - & - & - & - \\
\hline OMV Ceska republika, s. r. o. & $\begin{array}{c}\text { VIVA International } \\
\text { Marketing- und } \\
\text { Handels-GmbH }\end{array}$ & 100 & - & - & - & - \\
\hline OMZ B.V. & $\begin{array}{c}\text { OOO OMZ } \\
\text { (Obedinennye } \\
\text { mashinostroitelnye } \\
\text { zavody) }\end{array}$ & 100 & - & - & - & - \\
\hline Operator trhu s elektrinou, a. s. & $\begin{array}{l}\text { Ministry of Industry } \\
\text { and Trade of the } \\
\text { Czech Republic }\end{array}$ & 100 & - & - & - & - \\
\hline Paramo, a.s. & Unipetrol, a.s. & 100 & - & - & - & - \\
\hline Petrotrans, s. r. o. & BENZINA, s. r. o. & 100 & - & - & - & - \\
\hline Plzenska energetika, a. s. & $\begin{array}{l}\text { Energeticky } \\
\text { a prumyslovy } \\
\text { holding, a.s. }\end{array}$ & 100 & - & - & - & - \\
\hline $\begin{array}{l}\text { Power Exchange Central Europe, } \\
\text { a. s. }\end{array}$ & $\begin{array}{l}\text { Burza cennych } \\
\text { papiru Praha, a.s. }\end{array}$ & 100 & - & - & - & - \\
\hline Prazska energetika, a. s. & $\begin{array}{l}\text { Prazska energetika } \\
\text { Holding, a. s. }\end{array}$ & 57.87 & $\begin{array}{l}\text { Energie Baden- } \\
\text { Wurttemberg AG }\end{array}$ & 41.26 & $\begin{array}{c}\text { Other legal } \\
\text { entities and } \\
\text { private persons }\end{array}$ & 0.87 \\
\hline Prazska energetika Holding, a. s. & Hlavni mesto Praha & 51 & $\begin{array}{c}\text { Energie Baden- } \\
\text { Wurttemberg AG }\end{array}$ & 49 & - & - \\
\hline Prazska plynarenska, a. s. & $\begin{array}{l}\text { Prazska plynarenska } \\
\text { Holding, a. s. }\end{array}$ & 50.2 & $\begin{array}{l}\text { E.ON Czech Holding } \\
\text { AG }\end{array}$ & 49.35 & $\begin{array}{c}\text { Other legal } \\
\text { entities and } \\
\text { private persons }\end{array}$ & 0.45 \\
\hline Prazska teplarenska, a. s. & NPTH, a.s. & 48.67 & $\begin{array}{l}\text { Prazska teplarenska } \\
\text { Holding, a. s. }\end{array}$ & 47.33 & $\begin{array}{c}\text { Other legal } \\
\text { entities and } \\
\text { private persons }\end{array}$ & 4 \\
\hline Prazska teplarenska Holding, a. s. & Hlavni mesto Praha & 51 & Honor Invest, a. s. ${ }^{3}$ & 49 & - & - \\
\hline PREdistribuce, a. s. & $\begin{array}{c}\text { Prazska energetika, } \\
\text { a. s. }\end{array}$ & 100 & - & - & - & - \\
\hline Prvni energeticka, a. s. & $\begin{array}{l}\text { Energeticky } \\
\text { a prumyslovy } \\
\text { holding, a. s. }\end{array}$ & 100 & - & - & - & - \\
\hline RoBIN OIL, s. r. o. & Jiri Zoubek & 100 & - & - & - & - \\
\hline RPG Partners Limited & Zdenek Bakala & $?$ & $\begin{array}{l}\text { Crossroads Capital } \\
\text { Investments Inc. }\end{array}$ & $?$ & - & - \\
\hline RWE Gas Storage, s. r. o. & RWE Transgas, a. s. & 100 & - & - & - & - \\
\hline RWE Transgas, a. s. & $\begin{array}{c}\text { RWE Gas } \\
\text { International B.V. }\end{array}$ & 100 & - & - & - & - \\
\hline Severoceske doly, a. s. & CEZ, a.s. & 100 & - & - & - & - \\
\hline Shell Czech Republic, a. s. & $\begin{array}{l}\text { Shell Overseas } \\
\text { Investments B.V. }\end{array}$ & 100 & - & - & - & - \\
\hline Skupina CzechCoal, a. s. & $\begin{array}{c}\text { Czech Coal } \\
\text { Investments Ltd. }\end{array}$ & 50 & Czech Coal N.V. & 50 & - & - \\
\hline Slovak Gas Holding B.V. & E.ON Ruhrgas AG & $?$ & GDF Suez S.A. & $?$ & - & - \\
\hline $\begin{array}{l}\text { Slovensky plynarensky priemysel, } \\
\text { a. S., (SPP, a. s.) }\end{array}$ & $\begin{array}{c}\text { Fond narodneho } \\
\text { majetku Slovenske } \\
\text { republiky }\end{array}$ & 51 & $\begin{array}{l}\text { Slovak Gas Holding } \\
\text { B.V. }\end{array}$ & 49 & - & - \\
\hline SPP Bohemia, a. s. & $\begin{array}{c}\text { Slovensky } \\
\text { plynarensky } \\
\text { priemysel, a. s. }\end{array}$ & 100 & - & - & - & - \\
\hline
\end{tabular}




\begin{tabular}{|c|c|c|c|c|c|c|}
\hline Entity & Owner & $\%$ & Owner & $\%$ & Owner & $\%$ \\
\hline SPP CZ, a. s. & $\begin{array}{c}\text { Slovensky } \\
\text { plynarensky } \\
\text { priemysel, a.s. }\end{array}$ & 100 & - & - & - & - \\
\hline ENERGY 21, a. s. ${ }^{4}$ & $\begin{array}{l}\text { Natland Investment } \\
\text { Group B.V. }\end{array}$ & 16 & Mid Europa Partners & $?$ & $\begin{array}{l}\text { Golden River, s. } \\
\text { r. o. }\end{array}$ & $?$ \\
\hline $\begin{array}{l}\text { Skupina Trinecke zelezarny, a. s. - } \\
\text { Moravia Steel, a. S. }\end{array}$ & Moravia Steel, a. s. & 69.05 & CMC & 11 & $\begin{array}{l}\text { FINITRADING, } \\
\text { a.s. }\end{array}$ & 16.34 \\
\hline $\begin{array}{l}\text { Sokolovska uhelna, pravni } \\
\text { nastupce, a. s. }\end{array}$ & Frantisek Stepanek & 40 & Jaroslav Rokos & 30 & Jan Krouzecky & 30 \\
\hline SKODA JS, a. s. & OMZ B.V. & 100 & - & - & - & - \\
\hline UNIGEO, a. s. & $\begin{array}{l}\text { Kooperativa, } \\
\text { pojistovna, a.s. }\end{array}$ & 100 & - & - & - & - \\
\hline Unipetrol, a. s. & PKN Orlen SA & 62.99 & Publicly traded shares & 37.01 & - & - \\
\hline United Energy, a. s. & $\begin{array}{l}\text { Czech Energy } \\
\text { Holding,a.s. }\end{array}$ & 100 & - & - & - & - \\
\hline United Energy Trading, a. s. & United Energy, a. s. & 100 & - & - & - & - \\
\hline VEMEX, s. r. o. & ZMB GmbH & 51 & $\begin{array}{l}\text { Centrex Europe } \\
\text { Energy \& Gas AG }\end{array}$ & 33 & $\begin{array}{l}\text { EW East-West } \\
\text { Consult AG }\end{array}$ & 16 \\
\hline Vetrna energie $H L$, s. r. o. & $\begin{array}{l}\text { WEB Windenergie } \\
\text { AG }\end{array}$ & 100 & - & - & - & - \\
\hline $\begin{array}{l}\text { Verbundnetzgas (VNG) Energie } \\
\text { Czech, a. s. }\end{array}$ & $\begin{array}{c}\text { VNG - } \\
\text { Verbundnetz Gas } \\
\text { Aktiengesellschaft }\end{array}$ & 100 & - & - & - & - \\
\hline Vyzkumny ústav pro hnede uhli, a. s. & Czech Coal, a. s. & 44.58 & Severoceske doly, a. s. & 44.582 & $\begin{array}{c}\text { Individual } \\
\text { shareholders and } \\
\text { others } \\
\end{array}$ & 10.838 \\
\hline WINGAS GmbH \& Co. KG. ${ }^{6}$ & $\begin{array}{l}\text { Wintershall Holding } \\
\text { AG }\end{array}$ & 50 & OAO Gazprom & 50 & - & - \\
\hline ZMB GmbH & OAO Gazprom & 100 & - & - & - & - \\
\hline \multicolumn{7}{|c|}{$\begin{array}{l}1 \text { - The remaining } 11.944 \% \text { share of Dalkia Ceska republika, a. s. belongs to other legal entities and private individuals. } \\
2 \text { - In November 2010, the merger of Energie Bohemia, a.s. and Verbundnetzgas (VNG) Energie Czech, a.s. took place. The business } \\
\text { activities are continuing under the name Verbundnetzgas (VNG) Energie Czech, a.s. } \\
\text { - The sole owner of Honor Invest, a. s. is Energeticky a prumyslovy holding, a. s. } \\
\text { - The structure of shareholders of ENERGY 21, a.s. is very unclear, aside from the three above mentioned shareholders other } \\
\text { shareholders are likely to be GIHG Ltd. and Radiance Energy Holding. } \\
5 \text { - The remaining } 3.61 \% \text { share of Skupina Trinecke zelezarny, a. s., - Moravia Steel, a. s. belongs to other legal entities and private } \\
\text { individuals. } \\
6 \text { - Wintershall Holding AG owns } 50 \% \text { of the shares plus one, OAO Gazprom owns } 50 \% \text { of the shares minus one. } \\
\text { Source: Compiled by Tomáš Vlček from publicly accessible sources. }\end{array}$} \\
\hline
\end{tabular}




\section{Abstract}

This book addresses various aspects of the energy sector of the Czech Republic. There is hardly a more turbulent and more sensitive sector of the economy of the Czech Republic than the energy sector. As a result, its future is carefully monitored by not only the political and economic elite of the country, but also by the general public.

The book The Energy Sector and Energy Policy of the Czech Republic is divided into eight chapters. The first describes the key actors and the legislative framework of the energy sector of the Czech Republic, including an analysis of the Government, the Ministry of Industry and Trade, the Ministry of the Environment, and other legislative and regulatory bodies and political parties. The second chapter introduces the rich and complicated history of the development of the Czech national energy sector. The following chapters familiarize the reader with the coal, oil, natural gas, nuclear, renewables industries, and electricity and heat.

The book is recommended to scholars and researchers, as well as experts in the relevant fields of study, but will also serve as a guide for those outside academia who work with the topic daily, such as in public administration. Finally, the general reader can make great use of this book to gain a thorough yet accessible impression of the Czech energy sector. 



\section{Introduction}

In the Czech economy, no sector is more sensitive and, at the same time, more turbulent than energy. Its progress is carefully followed not only by business and political leaders, but it also has the attention of the broader public. The only reason for such a state of affairs is the fundamental influence which the energy sector has on every individual and company due to the prices of energy materials or of heat and electricity. The Czech energy sector, furthermore, abounds with unsolved problems, unanswered questions and obvious challenges.

In terms of raw materials exploitation, the manner in which the Czech Republic will manage its reserves of coal or uranium is as yet unclear. The nuclear energy industry stands at a crossroads, where a rather optimistic Czech Republic must react to 'Atomausstieg' impulses from its German neighbour. Legislative and managerial failure in supporting the photovoltaic sector has damaged the reputation of renewables as a whole, probably leading to their rather limited use in the Czech Republic for some time.

The issue of how to organize the energy sector itself has remained unresolved. CEZ, a. s. continues to dominate the Czech market as it has built up a position incomparable to any other local company. Besides advantages, this, naturally, brings also certain limitations, starting with the issue of excessive interconnection between CEZ and politics, through to the evident tendency towards monopolistic behaviour. Progressively greater attention is, however, being directed also to other energy companies active in the Czech Republic, which are gradually starting to express their assertive and predatory sides.

The influence of the European Union finds expression not only in terms of the often mentioned propagation of savings, environmental measures and renewables, but more importantly, in terms of the impact of EU legislation on the liberalization of the domestic energy sector. The formation of the single EU energy market is relevant even at the lowest levels, i.e. from those smallest users who since 2007 can choose their electricity and natural gas suppliers. That is, subsequently, tied to the distinctive change of regulatory organs, headed by the Energy Regulatory Office.

The media is also attracted by the foreign policy issues related to the energy sector. Dependence on oil and natural gas imports from sometimes unstable or authoritarian countries, the variation of world prices of commodities and discussion over their gradual exhaustion are often presented in newspapers and on television in a very provocative manner.

We could, of course, continue this list much further. The substantial point is that the Czech energy sector is and will remain a hot topic at both professional and lay levels. It is exactly the broader public that might feel a particular lack of the sources of information which could allow them to lead a decent debate addressing energy issues. Information concerning topical issues can be, of course, found in daily newspapers or specialized periodicals such as Energetika, Pro-Energy or All for Power, but there is an absence of more complex texts studying energy issues over a longer term and in broader contexts. Credible and undistorted information in that aspect holds the key for the public involvement, and this involvement is a natural and indispensable component of the modern democratic state's functioning.

These are also the reasons for this publication. Starting from a detailed historical excursion through the development of the Czech energy sector, we put forward basic information regarding individual energy commodities, electricity and heat, while we have devoted a part of the book also to some foreign policy issues. 
In the first chapter, we focus on the basic actors in the Czech energy sector as well as on its legislative framework. We will analyse in more detail the Government of the Czech Republic, the Ministry of Industry and Trade, the Ministry of the Environment as well as regulatory offices. We will, from different points of view, also devote attention to the relevant political parties; specifically, what role they have played during the formulation of strategic energy documents or the manner they saw energy issues as part of the Czech foreign policy. The chapter will close by delimiting the legislative framework of the energy and raw materials policy of the Czech Republic, including elaboration of the main documents and respective laws.

The second chapter presents the reader with the rich and sometimes complicated historical development of the domestic energy sector. The latter was characterised by two founding trends, i.e. the effort to shift from the socialist way of energy management to the common market model as well as gradual adjustment to the incentives coming from the European Union. We will, in chronological terms, introduce all three main intersections of the post-revolutionary development. As part of the first period, ended approximately in the mid-1990s, we will describe the restructuring of the centrally run energy system. In the second period, we will then observe the gradual privatisation of energy companies, including those of strategic state importance. Finally, in the last phase, initiated approximately by the Czech Republic's entry into the EU, we will witness the stabilisation of the situation and concentration predominately on completing the liberalisation of the energy market and, in general, the future development of the sector.

In reading the third chapter, the reader will learn in detail about the Czech coal sector. We go through the basic principles of mining and exploitation of coal, followed by a detailed description of sources, deposits, operating companies and trading in particular sorts of caustobiolith from the carbon series employed in the Czech Republic, i.e. lignite, brown coal and bituminous coal. We will also not leave out the respective forecast. Each chapter devoted to a particular sector always ends in an analysis of current issues and problems; within the coal sector, we will deal both with the issue of emissions allowances, since the emergence of the legislation at EU level, through implementation in the Czech Republic and its effects on the energy sector, as well with the issue of the territorial environmental limits on brown coal mining, which is one of the impetuses of the current Czech energy sector. This chapter will also present the basic parameters of the Czech heating supply sector, including the fuel mix.

The fourth chapter will give the reader a tour through the oil sector. Following a short historical excursion, the reader will be introduced in more detail to the oil source base for the Czech Republic, then to the deposits and extraction of oil, functioning of the oil market, including the description of companies and the process of oil trading. No less attention is given to infrastructure projects within the country's oil sector, with an emphasis on broader cross-border impacts. We also analyse the future of the Druzhba pipeline, which is one of the key topics for the oil sector.

The fifth chapter will duplicate the approach of the previous chapter, but with reference to the natural gas sector. The primary focus will be on infrastructure, i.e. domestic and regional infrastructural projects, development of the transmission system, cross-border interconnectors and increase in storage capacities.

The Czech nuclear sector is presented in the sixth chapter, and not only in terms of the nuclear energy industry but also with reference to uranium mining. The reader will learn about nuclear power plants within Czech territory as well as about the localities of uranium mining, coupled with information regarding companies trading in the sector and the principle of nuclear fuel trading. The reader will be acquainted in detail with the principle of the nuclear fuel cycle applied in the Czech Republic. In the concluding parts, the problem of the ongoing tender for completing the third and fourth blocks of the Temelin nuclear power plant will be addressed as the key point in the further development of the nuclear sector, relevant even beyond Czech territory. 
The seventh chapter addresses an especially sensitive issue in the Czech Republic, i.e. renewables. Clarification of the principle of energy production from individual types of renewable is a logical part of this section, as well as the presentation of the employment of these sources for electricity and heating purposes, together with the indispensable legislative and regulatory framework. In the second part of the chapter we will turn to the system of state support, the haphazard development of renewables over recent years and other current topics in this sector.

The eighth chapter is a specific chapter, since up to that point the book is divided into primary energy sources. Electricity, however, does not count as a primary source and this chapter to a great degree covers a lot of what was already mentioned in the previous parts about primary energy sources. The electric power industry, therefore, encompasses both the production (i.e. exploitation of coal, natural gas, uranium, sun, wind, etc.), as well as the transmission and distribution of electricity, including trading. For historical reasons, it de facto also includes the heating supply sector itself. Albeit it is, naturally, disputable to classify for example the heating sector at the same level as the nuclear or oil industry, we opted for such a division of chapters in order to give a good preview and comprehensive description and explanation of separate parts of the subject matter. In the eighth chapter we will present in more detail the functioning of the power system of the Czech Republic, including transmission, regulation and trading in electricity. We will also cover the regulatory framework applying to the electric power industry, concluding with reference to the current issues of stability and development of the transmission system, involving also the problem of implementation not only of renewables, but of larger cumulative capacities of sources such as the third and fourth blocks of the Temelin nuclear power plant.

Since the energy industry is a relatively complex topic, this book is supplemented with a number of tables showing and illustrating the relevant subjects of discussion.

The ambition of this publication is not to be a complete guide to the given subject, and the authors had to, for lack of space, leave out a number of issues. Accordingly, the book is not primarily intended for the direct use of experts in the field, who, as part of their tightly delimited fields, have available more detailed and expert works to consult. The target group is a broader public audience, predominantly including the academic, and it strives to give a more complex picture of the given sector, to lay out the problems and provide knowledge for further studies or contemplation. For that reason, we hope that this publication will meet the indicated purpose and that it will be useful to the fellow reader in his or her efforts to become acquainted with the very interesting story of the Czech energy sector. 



\section{Chapter 1: Actors in, and the Legislative Framework of, the Czech Energy Sector ${ }^{1}$}

Tomáš Vlček, Filip Černoch, Veronika Zapletalová

The energy sector of any state, including the Czech Republic, presents an active arena, comprising of the clash of interests and priorities of a diverse spectrum of actors - starting from offices of state through to private companies. Providing a concise characterization of at least the state-representing actors - their competence, influence, interests and activities - is therefore a logical part of this book. In the second part of the chapter this information will be supplemented with an assessment of the legal framework of Czech energy, including the introduction and evaluation of basic conceptual documents and reports.

Given the broad subject matter, we will narrow the entire issue down to the period from 2006, with the commencement of the Government of Mirek Topolanek, through to now.

\subsection{State Institutions}

\subsubsection{The Prime Minister}

Both formally and in reality, the Government is in overall charge of the entire sector, operating through the Prime Minister of the Czech Republic. As the winner of parliamentary elections, the latter is entrusted to form the Government. The Prime Minister, as well as other members of the Government (primarily Minister of Industry and Trade and Minister of the Environment), proposed by the Prime Minister, are appointed by the president.

Following the 2006 elections, the post of the Prime Minister went to the president of the winning Civic Democratic Party (ODS), Mirek Topolanek. However his first formed Government, with M. Riman as Minister of Industry and Trade and P. J. Kalas as Minister of the Environment, failed to pass a vote of confidence. The Chamber of Deputies finally declared its confidence in the Government on January 9, 2007. Even though the opposition overthrew Topolanek's government on March 24, 2009, it remained in power until May 8, 2009, when it was replaced by a non-partisan Government headed by Jan Fischer. From June 13, 2010 till July 10, 2013, the country has been led by the Government of Petr Necas.

As previously indicated, the Prime Minister is in overall charge, which is why we need to turn more attention to the relevant ministries; specifically to the Ministry of Industry and Trade and the Ministry of the Environment.

1 This chapter makes substantial reference to the text The Czech Energy Policy as the Matter of Political Parties'DecisionMaking: Aggregation and Articulation of Interests in terms of Their Intensity and Consistency (see Černoch, Zapletalová, Vlček, 2010, p. 255-284). 


\subsubsection{The Ministry of Industry and Trade}

In terms of formal competences, this is the central government body for Energy Policy, the creation of an Integrated Raw Materials Policy and the Use of Mineral Resources. It is also the central government body for commodity exchange, except for issues coming under the Ministry for Agriculture, also supervising inspections in the energy sector. This ministry is also responsible for legislative coordination and implementation of European law within the department. Finally, the Ministry of Industry and Trade is the author of the State Energy Concept and revisions thereof (see MPO, 2010a).

Given his authority, being Minister of Industry and Trade provides a great opportunity to give Czech energy policy a specific shape. What is crucial here is the functioning of the Ministry of Industry and Trade itself is significantly influenced by the particular person who is currently minister.

Following the elections to the Chamber of Deputies of June 2-3, 2006, this job was given to the liberally-oriented electrical engineer and lawyer Martin Riman (ODS). His appointment was not followed by any special political disputes, but this was not the case during his term of office, when criticism predominately came from the coalition Green Party and opposition Social Democrats (CSSD). They were, above all, dissatisfied with his role in the preparation of the National Allocation Plan ${ }^{2}$ for 2008-2012, where he arranged for the Czech Republic to receive an average 101.9 million tonnes of emission allowances per year, a $25 \%$ increase on 2005. In this context he was criticized for allowing an increase in the emissions burden on the environment, although in these terms he actually never betrayed the election campaign program of his party because this had never mentioned emission limits (see EK, 2006a).

He also received a great deal of criticism for supporting the breach of territorial limits on brown coal mining in North Bohemia and consenting to the building of two additional blocks in the Temelin nuclear power plant. For these activities Martin Riman won the (anti)award 'Gobbler of the Year' in 2006, but on the other hand we can say that these activities to a great degree stemmed from the 2004 State Energy Concept (see Anketa Ropák \& Zelená perla, n.d.).

Following the appointment of the Jan Fischer's Government on May 8, 2009, Martin Riman was replaced as Minister of Industry and Trade by a non-partisan, Vladimir Tosovsky, nominated by the Czech Social Democratic Party (CSSD), also an electrical engineer, with rich working and professional experience in the field. In his year in office, he pursued a more conservative energy policy based on domestic resources. The energy concept he proposed accepted the breaching of mining limits, the extension of uranium mining, coal mining in Beskydy and greater exploitation of nuclear energy (see Kubátová, 2009).

In the new Government headed by Petr Necas, the post of Minister of Industry and Trade was, on June 13, 2010, assumed by the economist Martin Kocourek (ODS); therefore, after a long time a politician without expertise and a professional background in the energy sector. ${ }^{3}$ Neither did he hide his inclination to more robust exploitation of nuclear fuel and coal, remaining in post long enough to see through a new draft State Energy Concept planning to extend Czech nuclear power by 15 blocks with 1,000 MW capacity each. Both experts and the general public strongly opposed this idea for its unrealistic calculations and the unfeasibility of the construction (see Lukáč, 2011). Martin Kocourek lost his position through a financial scandal, in which he practically confessed he had swindled his wife out of part of their joint property during divorce proceedings (see "Ministr Kocourek rezignoval").

2 The key element of the EU ETS emission allowances trading system is that it decides how allowances will be allocated in the Czech Republic and to what companies.

3 We should not however understate his activity in the Supervisory Board of CEZ, a.s. in 2006-2010. 
Accompanied by publically expressed discomfort ${ }^{4}$, on November 16, 2011, the vacant ministry was filled by Martin Kuba (ODS). The latter announced the preparation of a new, more balanced revision of the State Energy Concept, took a long-term stand counting on the nuclear power industry, including support for completion of the Temelin nuclear power plant, and accordingly not hiding a notably critical position toward further support for renewables.

If we look at the previously mentioned group of ministers, we can see a major similarity of their preferences and ideas on how the Czech energy sector should look in the future. The latter should be, from their point of view, founded on local resources, meaning coal, while they also called for uninterrupted support for the nuclear power industry. What they also had in common is their restrained attitude towards renewables and reliance on savings and energy efficiency. Scepticism towards energy-environmental proposals coming from the European Union was prominent, with individual ministers accepting them only to the minimum possible extent.

Aside from specific ministers, the Ministry of Industry and Trade can in any case be marked as one of the main creators of the Czech energy sector, at least at the level of public administration. Its authority and influence rank highly at the level of the Czech Republic, while playing a much lesser role in international forums and at EU level, sharing it, for example, with the Ministry of Foreign Affairs.

\subsubsection{The Ministry of the Environment}

The other important body in the energy field is the Ministry of the Environment. This is the central body of the government administration for protection of the environment in general, for operation of the National Geological Survey, protection of the mineral environment, including mineral resources and groundwater, geological works and environmental mining supervision. It is also responsible for environmental impact assessments of activities and their consequences, including cross-boundary ones, and stands behind the National Environmental Policy. As part of safeguarding and control activity of the Government, the Ministry of the Environment coordinates activities of an environmental character performed by all ministries and other central administrative authorities (see MŽP, 2010).

Like the Ministry of Industry and Trade, the Ministry of the Environment is strongly affected by the person at the top. Following the 2006 elections, the post of Minister of the Environment was assumed by a non-partisan, Petr Jan Kalas. After some five months, on January 9, 2007, he was replaced by the then president of the Green Party, Martin Bursik. With his arrival the Ministry of the Environment experienced an era of a very active and important role within the Czech energy sector.

As a representative of the new party in the Parliament, the Green Party, Martin Bursik's aspirations be Minister of the Environment were logical. In relation to electoral success (6.29 \%, 6 MPs in the Chamber of Deputies), this position then provided the Green Party with sometimes even excessive negotiating power. Such a position coupled with the post of Minister of the Environment helped the Green Party to find a way to implement basically all the crucial energy points of its election campaign program, specifically environmental tax reform, an Act on Promotion of Renewable Energy Sources, postponement of a decision on construction of new nuclear power plants and departure from the policy of breaching the

4 Aside from the lacking education in the field, the new minister was reproached also for his previous alleged connection with the company PSM, based on the principle of a pyramid scheme, as well as for his disputable working activity in the SouthMoravian Region, where he came into contact with one of "the ODS godfathers", Pavel Dlouhy (see Kopecký, Štastný, 2011). 
environmental territorial limits on brown coal mining ${ }^{5}$ (see SZ, 2006, p. 14-18). Here we must point out that the great success the Ministry of the Environment and the Green Party achieved at the level of political decision-making and approval processes during 2006-2009 was not due to the extraordinary capabilities of the Green Party members, but rather the political circumstances which at the time proved to be very advantageous for this party.

Passing the above-mentioned propositions would have been most probably impossible, if the result of 2006 elections had not been an impasse and if the coalition government had not been so dependent on just six Green Party MPs. While the policy statements of the Green Party and of the other governing party, the Christian and Democratic Union - Czechoslovak People's Party (KDU-CSL) were rather alike (mainly in the field of territorial environmental limits on brown coal mining, exploitation of renewables and energy savings) and a consensus could be expected even without the impasse after the 2006 elections, the consensus between the Green Party and the leading government party, the Civic Democratic Party (ODS) on postponing the decision on construction of new nuclear power plants and on departure from the breaching of the territorial environmental limits on brown coal mining should be to a great extent perceived as a result of the indecisive election result and the need to cooperate (see KDU-ČSL, 2006, p. 40). Proof lay in the fact that when the coalition started to collapse, the political power of the Green Party dropped significantly. The first serious sign of this was in February 2009, when the Chamber of Deputies rejected a draft amendment to the Environmental Assessment Act proposed by M. Bursik, lacking votes from the coalition ODS and KDU-CSL parties (see ČT24, 2009).

After Jan Fischer's Government was appointed on May 8, 2009, another rotation at the post of Minister of Industry and Trade occurred, making way for the non-partisan Ladislav Miko, nominated by the Green Party. ${ }^{6}$ This educated biologist and environmentalist with a long working experience, for example, in the Czech Environmental Inspectorate, was during his mandate at the Ministry on leave of absence from the position he had in the Directorate-General for the Environment, to which he returned in 2009 (see "Fischer by rád"). On November 30, 2009, the position of Minister of the Environment was taken by the non-partisan (he suspended his membership in the Green Party for the function) Jan Dusik, also nominated by the Green Party. On March 19, 2010, he resigned from this post over the dispute about the reconstruction plan for Prumerov power plant, and on April 15 the Ministry of the Environment was taken over by Rut Bizkova, who had some experience in the energy field - somewhat surprisingly, however, as spokeswomen for CEZ coal power plants and as Counsellor to the Deputy Minister of Industry for energy, metallurgy and civil engineering.

As in the Ministry of Industry and Trade, during the Necas Government, two ministers rotated at the Ministry of the Environment as well. The first of them, Pavel Drobil, left at the end of 2010 (he, therefore, stayed in post for about six months) over suspicion that he might have influenced investment tenders commissioned by the State Environmental Fund of the Czech Republic (see “Tajné nahrávky"). He was replaced by the political scientist and lawyer, Tomas Chalupa, who devoted the initial year of his mandate to the dispute that then raged over the Sumava National Park on and the problematic Green Savings Program.

As already said, the Ministry of the Environment is a key actor in the Czech energy sector, mainly as a result of having the authority to interfere in the approval processes of various energy projects as well as having an effect on the final version of legal acts relevant to the energy sector.

5 Among all parties succeeding at the 2006 elections, the Green Party had the best developed approach concerning the Czech energy sector.

6 Ladislav Miko accordingly stayed as Chairman of the Directorate for Nature within the Directorate-General for the Environment under the European Commission. He got two months leave for performing the function of minister and, given the unanticipated delay of early elections, he was forced to resign from that function. 
Based on the order of things, it also to some extent is a counterpart to the Ministry of Industry and Trade. One pursues the goal of a well-functioning industry and energy sector, the other of ensuring that this affects the environment as little as possible. The ODS' efforts to "de-green" the Ministry are in this context noteworthy, given that this party has never hidden its reservations regarding this issue. "We want to proceed with a non-dogmatic, non-ideological approach", said, for example, Prime Minister Necas when launching Chalupa (see Dolejší, Frouzová, 2011). "Perhaps he is a competent administrator and uncorrupted politician. However, he is certainly constantly linked to Pavel Drobil. The department will be managed so as not to obstruct industry, agriculture and transport and not to make problems", was the less obliging reaction of the Greenpeace Program Manager, Michal Komarek (see Dolejší, Frouzová, 2011).

It is more than apparent that, unlike the ministers Miko, Bursik or Dusik, not only did their successors Bizkova, Drobil or Chalupa not have much experience in the subject matter, but neither were they too willing to perceive the Ministry of the Environment as a tool for balancing the interests and activities of the Ministry of Industry and Trade and of the industry sector in general. It is, therefore, symptomatic that as part of the bureaucratic government, which was in preparation in the period when this text was written, the post of Minister was offered to Radek Spicar, Vice-President of the Confederation of Industry of the Czech Republic, Executive Director of the Czech Branch of the Aspen Institute and former Director of External Affairs in Skoda Auto.

\subsubsection{Monitoring Bodies and Other Institutions}

The State Energy Inspection (SEI) performs a monitoring function, prompted by the Ministry of Industry and Trade, the Energy Regulatory Office or based on its own initiative. Its responsibilities are the supervision of adherence to The Energy Act, the Act on Prices, regulation of conditions for access to the network for cross-border exchanges in electricity and the Act on the promotion of electricity production from renewable energy sources. It also has the power to impose fines. ${ }^{7}$

The Energy Regulatory Office (ERU) is a body with a significant level of authority, to a great degree stimulated by the European Union. The ERU sets the rules for business activities in the energy sectors as well as the rules of trading. The Office establishes the business conditions of the electricity market operator, decides on disputes over access to the network and performs a number of other functions. ${ }^{8}$

The rather stable relationship and distribution of power between these two institutions was interrupted by an amendment to The Energy Act from August 18, 2011 (Act No. 211/2011 Coll.), which emerged primarily as a reaction to the Third Liberalization Package of the EU. The latter gives a significantly larger scope of authority to the Energy Regulatory Office: "One of the new major competences will be inspection of the electricity and gas markets in order to decide on the existence of competitiveness in these markets and imposing measures (in matters not under the authority of the Office for the Protection of Competition). As part of this inspection, the ERU will have a number of powers, among others to enter business premises, inspect business records, seal premises, etc. Finally, the ERU will monitor compliance with the provisions of The Energy Act on protection of customer's interests in business activities in the electricity and gas sectors" (see Pravda, 2011, p. 39).

The improvement of the ERU's position is interesting also in terms of significant changes which occurred within its management. The then Chairman of this "small Energy Ministry", Josef Firt, was on

7 For more details see for example "Státní energetická inspekce".

8 For more details see for example "Energetický regulační úřad”. 
August 1, 2011, replaced by Alena Vitaskova. Her appointment provoked diverse reactions, mainly over her previous employment as Chairwomen of the company Transgas and her stake in Vemex, partly owned by Gazprom (see Léko, 2011a). The main objection was that the management of the principal energy regulatory body should not have such close ties with specific (regulated) companies.

The last of the important regulators of the Czech Energy market is The Czech Electricity and Gas Market Operator (OTE). It evaluates and counts the consumption or supply imbalances of each market participant, organizes the short-term electricity market and energy balancing market, the preparation of market reports and their consumption forecasts and their management. It administers the National Register of Greenhouse Gas Emissions as well as the trading portal of electricity from the combined generation of electricity and heat. Unlike the other mentioned institutions, it is a joint stock company, with an at least $67 \%$ state share set by law. ${ }^{9}$

\subsection{The Legislative Framework of the Energy and Raw Materials Policy of the Czech Republic}

The founding strategic document which was the flagship of legislative development in the first half of the 90s was the Energy Policy of the Czech Republic, adopted at the beginning of 1992. It was of rather declaratory character, primarily aiming at completing the processes of privatisation and restructuring within the energy sector, alteration of the legal framework so as to involve new provisions as well as the formation of a regulatory body for the energy sectors. The long term aim of this document was to form an active price and tax policy, support competition in the field of energy production and harmonize Czech legal norms with those of the EU (see Stehlík, 2000, p. 152-156).

This whole framework then underwent changes in the basic legal acts. In the first place, the trio of electricity, gas and heat supply legislation needed a replacement as it was set up for the conditions of central planning and the presence of state companies, and was therefore in many aspects incompatible with the market-driven setting of the newly emerging joint stock enterprises and other energy market entities (see Neužil, 1995, p. 1).

Work on these acts was taking place since 1992, while it was later decided to bring them together into one paper, which was, moreover, supplemented by an amendment to the Act on the State Energy Inspection. This body monitors compliance with energy laws, exercises the right to impose fines and define $^{10}$ their scope (see Neužil, 1995, p. 2). The resulting Act on business conditions and on the execution of state administration in power industries and on the State Energy Inspection, usually called the "The Energy Act", was adopted on November 2, 1994, and entered into effect on the first day of January in the following year. In that way it became the third multifaceted legal act in the history of Czechoslovak, and later Czech, energy legislation. ${ }^{11}$

9 For more details see for example "Operátor trhu s elektřinou”.

10 Even though a part of that authority was transferred to the Energy Regulatory Office in 2011, in line with the adopted amendment to The Energy Act.

11 It followed Act No. 438 from 1919 on state support during the commencement of systematic electrification and the previously mentioned Act No. 79/1957 on the production, distribution and consumption of electricity (for more details, see Neužil, 1995). 
This sort of a "basic code" of the Czech energy law has for twenty years delimited the terms of business activities within the energy sectors, therefore, in sectors of electricity, gas and heat production and distribution, in the public interest. It also defined the state role in relation to business subjects and determined relations between energy suppliers and energy users. It was gradually supplemented by Act No.18/1997 Coll. on peaceful utilization of nuclear energy and ionizing radiation, regulating the requisites of nuclear power plant operation and the treatment of fuel and waste (the so-called "The Atomic Act") and Act No. 309/1991 Coll. on the protection of air from polluting substances, having an influence on the desulphurisation of coal power plants. A bit later, in 1999, Act No. 189/1999 Coll. on emergency oil reserves and on emergency oil management was passed (see Neužil, 1995).

We should also mention the preparation of the new energy policy in the second half of the 1990s, which ended unsuccessfully. The first new attempt to arrive at a new version of policy was made by Minister of Industry and Trade, Vladimir Dlouhy, in his proposal emphasizing an entire line of environmentally-friendly measures and focussing on the formation of an independent energy monitoring office. The document, however, did not even get to be considered by the Government. ${ }^{12}$ His work was continued by Karel Kuhnl, who in the new document counted on a rather gradual inhibition of coal mining, the development of the nuclear power industry, including completion of the Temelin nuclear power plant and modernization of the Dukovany nuclear power plant, as well as pressure for the liberalization of the energy market. Due to the early elections in 1998, deputies did not get to pass this document. The incoming Minister, Miroslav Gregr, in the end authorized the preparation of an entirely new draft which followed his own priorities.

\subsubsection{State Energy Concept}

The 1990s were years of major change at the level of both Czech energy as well as of the EU which the country was heading towards. At the internal state level, there was a shift from a centrally regulated energy trade towards a significantly more market-like milieu accompanied by a gradual removal of state interference, such as subsidized electricity prices. However, environmental taxes had not been implemented yet, the energy legislation regulating the monopoly and final electricity consumption were not completed, while the unfinished privatization of energy companies represented a major weakness. The lack of success was then addressed by the policy of energy saving and more intensive exploitation of renewables. ${ }^{13}$ In line with events at EU level, the Czech Republic was compelled to respond to legislation associated with strong liberalization efforts in the field of natural gas and electricity.

All these and many other changes demanded the preparation of a new conceptual document regulating the long term future of the Czech Republic, resulting in the 2000 State Energy Policy of the Czech Republic (SEP 2000). The latter is perceived as the first truly detailed strategic and conceptual document of its kind which was adopted with clearly defined objectives and means to reach them, moreover, making an increasing contribution to closing the energy chapter as part of the EU Accession Negotiations.

The first issue which the SEP 2000 framework solved was rectifying the price and tariff structure of energy commodities and associated services, mainly by removing cross subsidies and charging less for households at the expense of industry users. The solution was supposed to bring a progressive rise in prices and their complete market setting by 2002 .

12 For more details on the proposal, see Šálek, 2004.

13 The summary is based on the document Energy Policy of the Czech Republic (see Energetická politika České republiky, 2000, p. 3). 
The document also addressed the very sensitive matter of the final privatization of state shares in the key energy companies, specifically in CEZ, Transgas, CEMPRO, MERO and Unipetrol. With the exception of the latter, the state was, according to the Policy, supposed to keep a degree of influence in each of them, while it was intended only to transform Transgas, CEMPRO and MERO into joint stock companies under full state ownership. The privatization issue was also connected to the need for an independent regulatory body, which would in future supervise the Czech energy sector.

The document responded to the abovementioned EU requests by calling for setting of regulations which would pave the way for an internal electricity and gas market, distinguished by users' ability to choose the supplier of these energy commodities. SEP 2000, furthermore, proposed some environmentally-friendly measures for exploitation of renewables, promoted saving measures and emphasized the combined generation of electricity and heat, devoting a part of the document to the support of domestic mining and the very optimistic future of the nuclear energy sector.

Approximately at the same time as the State Energy Policy started to be prepared, the preparation of the new Energy Act was initiated as well, motivated primarily by an effort to adjust the Czech legal framework in line with European demands, therefore, mainly in accordance with the Directive concerning common rules for the internal market in electricity (96/92/EC) and gas (98/30/EC). The resulting Act No. $458 / 2000$ Coll. on business conditions and public administration in the energy sectors and on amendments to other laws (again called "The Energy Act") predominantly regulated access of third parties to the network, introduced the term of public administration, defined an authorization principle for construction of new energy capacity, an obligation to keep separated accounting across specific activities and introduced gradual liberalization of the electricity and gas market. The interesting part of the law was an obligation to perform regular evaluation of the current energy policy every two years (see Šindler, 2006, p. 10-13). That was meant to prevent recurrence of the situation from the beginning of the 1990s, when the political will to create any conceptual document of this sort did not exist and the energy entities in that manner were left only to anticipate what the state had in mind for the future.

The Act also set up the Energy Regulatory Office for the electricity, gas and heating sectors, the body which exercised the power of regulating affairs in the energy field. It also gave rise to the Czech Operator of the Electricity Market. The Act was naturally repeatedly amended, while the most notable changes were made in 2003 by Act No. 278/2003 Coll. (regulating the schedule of electricity market opening) and by Act No. 670/2004 Coll. in 2004 (see Šindler, 2006, p. 16). Persistant market liberalizing efforts as well as the accompanying protection of customers were then repeated in the revision of The Energy Act from 2011.

Together with The Energy Act, Act No. 406/2000 Coll. on energy management was passed as well. The document primarily aimed at reaching maximum efficiency during production, transmission, distribution and consumption of energy, also including the rules for making the means of achieving those aims. Some of the Act's parts are, for example, obligations of construction companies and building owners, labelling of appliances according to their energy efficiency or guidelines for preparation of the State Energy Concept and Territorial Energy Policy.

Admission to the European Union was the pretext for adoption of Act No. 180/2005 Coll. on the promotion of electricity production from renewable energy sources.

In line with the provisions of The Energy Act, at the end of 2001 whether the requirements of 2000 SEP had been met was evaluated, followed by a conclusion that the majority of the short and long term goals had been accomplished. At that point, however, unions and the entrepreneurial sphere were asking for a comprehensive revision of the policy in order to make the state's long term goals clearer, so that they could adjust their business decisions on that basis. A decision on preparation of the updated State Energy 
Policy was, in that manner, classified as the priority of the new government. This decision-making was additionally burdened by persisting problems concerning the incomplete transformation of energy management, its environmentally still inadequate character and admission to the EU (see $K$ aktualizaci státní energetické koncepce, 2003a, p. 39).

\subsubsection{Strategic Documents in the New Millennium}

The 2000 State Energy Policy was followed by several foundational papers, mainly the 2004 State Energy Concept, the Paces report and the Updated State Energy Concept from February 2010 (SEK 2010).

The 2004 Energy Concept (SEK 2004) strongly revised the by that time stressed (and to the greatest measure accomplished) priorities. Instead of the previously emphasized restructuring and privatization, attention was turned to the specific measures for the further long-term functioning of the sector. SEK 2004 was, moreover, to a certain degree a necessary reaction to Czech obligations at the level of the EU (usually referring to the promise to produce a specific percentage of electricity from renewables) and the fact that 2005 was getting closer, when another evaluation of coal mining limits from 1991 was to take place.

The body responsible for the preparation of the Concept already in 2003 was the Ministry of Industry and Trade, at the time headed by Milan Urban (CSSD). His Deputy, Martin Pecina (CSSD), previously General Director of the public company Hutni projekt Frydek-Mistek, also played a crucial role. The Ministry's draft worked with six different scenarios of development, varying according to the energy mix composition. The Ministry itself, however, opted for the one marked as Green, finding it the best, and basically the only appropriate option. The latter laid emphasis on the maximum Czech independence from fuel imports, which would be reached by employment of domestic sources, and on the sustained self-sufficiency of the Czech Republic in the field of electricity production. The specific tools for reaching these objectives were assigned to a broader use of nuclear energy and the construction of new coal power plants (connected to the possibility of mining beyond the territorial limits). SEK 2004 projected a smaller increase in natural gas employment, especially as it needed to be imported, as well as a rather limited role of renewable sources of energy (see MPO, 2004).

The Ministry of the Environment, headed by Libor Ambrozek (KDU-CSL), developed strong reservations about this concept. Its office even prepared its own alternative version of the Energy Concept, highlighting energy savings (for example, in the form of thermal insulation of homes), more active use of renewables and a higher level of natural gas employment. The key problems which caused the crucial clash between the Ministries were exactly the breaching of territorial limits on mining and continuing construction of power plants. Following the several times repeated postponement of discussion over the final version of the document, accompanied by public protests organized by environmental organizations and representatives of mining-affected municipalities, the two parties came to a compromise. It basically followed the trend set by the Ministry of Industry and Trade, however, dropping specific requirements referring to the breach of mining limits and asking only for their re-evaluation in the future. ${ }^{14} \mathrm{As}$ far as nuclear energy is concerned, SEK 2004 continued to count on the construction of additional (not three, but two) blocks.

14 "The extracts on the breaching of territorial mining limits were left out of the concept, replaced by the formulation of their rational evaluation in the future," said spokeswomen of the Ministry of the Environment, Ms. Karolina Sulova (see "Vláda schválila energetickou koncepci”). 
It is evident there were a clash of interests between two ministries over this concept, namely the Ministry of Industry and Trade and the Ministry of the Environment. All the main participants in the debate, Libor Ambrozek, Martin Pecina and Milan Urban, had basically followed the policy advocated by their parties, which, however, did not see this issue as a priority of the highest rank. The entire preparation of the concept proceeded rather in terms of a different focus the ministries (where the Ministry of Industry and Trade was generally inclined to a rather centralized character of the energy sector with massive sources and priority laid on electricity production, the Ministry of the Environment was rather interested in energy savings, renewables and landscape preservation) and the chief representatives (L. Ambrozek, as an environmentalist and a long term opponent of the nuclear energy, and M. Urban and M. Pecina as proponents of "the traditional" Czech energy sector, underlining the state role and use of local sources) had.

Some of the factual matters as well as debates over the preparation of this concept are addressed in other parts of this book, but here we can basically argue that it is exactly this concept that had brought the process of the Czech energy policy to an end at its strategic and legislative levels. The elementary legal framework treating this segment of the economy was created, which can, moreover, stand shoulder to shoulder with its western counterparts. The energy sector stopped being seen as a field which can survive by being left to free market forces and seeking for the state intervention only when necessary, and it became a more predictable and stable system of updated concept documents (policies, concepts), showing the direction of the energy sector over longer time horizons.

Since then, we can, accordingly, follow a clear delimiting of two fields which will affect the Czech energy industry in the future. It is, in the first place, the unsettled debate on the (non)breaching of coal mining limits, while the issue of the local development of nuclear industry is drawing similar attention.

What was now gradually becoming a traditional mechanism of cyclic preparation of conceptual documents (energy policies) in 2008 welcomed a less typical document, named the Report of the Independent Expert Commission for Establishing Energy Demands of the Czech Republic (the Paces Commission). This paper came in the aftermath of disagreement within the then governing coalition, which split over a nuclear sector matter and further use of coal beyond the territorial limits. According to the official explanation, this report was supposed to be some sort of "an expert guideline" for where the future Czech energy sector was supposed to be heading.

The report emerged as a result of the hard coalition negotiations between the Civic Democratic Party (ODS), the Christian Democratic Union - Czechoslovak People's Party (KDU-CSL) and the Green Party in the second Government headed by the Prime Minister Topolanek (from January 9, 2007). The parties which participated in the negotiation process had the following preferences: The ODS, in energy matters represented by Minister of Industry and Trade Martin Riman, perceived nuclear energy as the indispensable source and its development, therefore, as the natural order of things, while affiliations were overall rather turned to a substantial exploitation of coal as an important energy source. ${ }^{15}$ Both were absolutely at odds with the interests of the Green Party, a future coalition partner. The KDU-CSL as the third government party-to-be took a rather moderate, even indistinct stance, rather close to the ODS' point of view. ${ }^{16}$

15 Although these topics do not show up in the 2006 election campaign program and the energy sector was here mentioned only in relation to the need for a higher degree of energy efficiency within the economy (see ODS, 2006).

16 Neither does his election program in any specific manner deal with the energy issue. Although Libor Ambrozek, opponent of the mentioned subjects, was still an active member of KDU-CSL, this party generally took a rather pragmatic stance (see KDU-ČSL, 2006). 
The resulting agreement formulated in the Government Decree for that reason had to unavoidably express a compromise between these interests, while we may add that it was accordingly a substantial success for the Green Party. Not only did the Party enforce a foundational part of its environmentally-relevant energy objectives such as insistence on a reduction in greenhouse gas emissions, but it also sustained its priorities in the field of the nuclear sector and coal mining limits: "The territorial limits on brown coal mining will remain. The Government will neither plan nor support the building of new nuclear blocks and, after consultation with the opposition, based on a consensus of all three political parties sitting in the Government, set up an Independent Expert Commission to assess the energy requirements of the Czech Republic in the long term" (see VČR, 2007).

The ODS placed quite strong hopes in this commission, trusting that its findings, provided they were neutral, at least concerning the nuclear sector, might serve it as a tool to make an impact on the Green Party and change its position leading to compromise. The Paces Commission was set up in January 2008, but the parties did not nominate representatives to it until April of the same year. The CSSD, moreover, announced that it would not participate in the Commission's work at all. "There is no reason when our representatives would only assist there in disputes between the Green Party and the ODS, which the Commission will surely not be able to avoid", declared shadow Minister of the Environment, Petr Petrzilek from the CSSD (see Břešt’an, 2007).

Gradually released findings of the report raised strong emotions. After the release of the initial incomplete report, the Green Party blamed to the Commission for its unprofessional and incorrect conduct (directed to Deputy President Kuchtova), M.Bursik even marked the whole Commission was a biased body as it included former Minister of Industry and Trade, V. Dlouhy ${ }^{17}$, whose previously written pro-nuclear materials were not supposed to be considered by the Commission in any thorough manner (see Pavlovič, 2008). A very negative reaction also came from M. Riman, who called it all "a trick" and an effort to sweep under the carpet those parts of the report which were inconvenient for the Green Party (see "Řiman: Odmítáním výsledků Pačesovy komise”).

Given the fragile governmental coalition and apparent preparedness of the Green Party to leave it if any fundamentally pro-nuclear or pro-coal propositions were passed, the conclusions of the Paces commission remained basically only on paper, without direct or specific guidelines for their execution.

In terms of its contents, the Paces report was a decent document mapping the situation and needs of the Czech energy sector. In terms of the traditionally sensitive points of the Czech energy sector, the report concludes that nuclear energy has and should have its place in the Czech energy mix, although the text is not significantly optimistic with regard to nuclear, on the other hand, it does not call for the breaching of mining limits, but it does not further consideration (see "Zpráva Nezávislé odborné komise”).

The Energy Act establishes the regular updating of the State Energy Concept, which is why the Ministry of Industry and Trade had started preparing its revision already during the commencement of the Paces commission, resulting in the 2010 State Energy Concept, which at least in its initial phase did not raise any great public or political attention.

17 The Commission consisted of: Chairman - Vaclav Paces, President of the Czech Academy of Science; ODS - Vladimir Dlouhy (former Minister of Industry and Trade, Counselor of Goldman Sachs Bank), Frantisek Hrdlicka (Dean of the Czech Technical University in Prague); KDU-CSL - Ales Dolezal (member of the Association of Energy Managers), Josef Bubenik (Chairman of the Czech Energy Agency); KSCM - Petr Otcenasek (independent counselor in the energy department), Miroslav Kubin (member of the Association of Energy Managers); Green Party - Vladimir Vlk (energy auditor), Edvard Sequens (counselor in the energy field, Calla Association); CSSD - refused to nominate its representatives in the Commission. 
Already at the beginning of 2009, the Ministry of the Environment led by president of the Green Party, Martin Bursik, commented on the practically completed draft, now however not insisting on complete elimination of the formula concerning the need to extend nuclear energy in the Czech Republic, but narrowing the requests only by asking for their maximum safety. "We are not fundamentally against it, if our remarks are noted. We are not fundamentally against nuclear energy," said spokesman Jakub Kaspar (see Srámek, 2009). In terms of the Green Party's agenda, it was a very dramatic movement, albeit the Green Party and ODS continued to have absolutely different stances on coal. It was exactly this issue, together with the maintenance of uranium mining, that SEK 2010 addressed.

Aside from the already traditional clash between the Ministry of Industry and Trade and the Ministry of the Environment, the debate over SEK 2010 was also joined by the CSSD.

It first started with M. Urban's unhesitating request for the Government to involve the social democrats more in the document's preparation, then with a particular criticism coming from shadow Minister of the Ministry of the Environment, Petr Petrzilek. He described this piece of work as amateurish, poorly addressing issues of the environment, energy efficiency, energy savings and raw materials treatment and not reflecting the conclusions of the Paces commission, the Integrated Raw Materials Policy of the Czech Republic nor EU obligations (see Petržílek, 2009).

The preparation of the State Energy Concept was, naturally, significantly influenced also by the change of Government, when Topolanek's cabinet was replaced by the bureaucratic Government led by Jan Fischer. Represented by Minister of Industry and Trade and former leader of CEPS, V. Tosovsky, this Government worked on the final form of the concept which emphasized maximum use of domestic raw materials, including nuclear and coal, enhancement of energy efficiency and pro-export orientation of the future electricity sector. In terms of political viability, it was precisely Vladimir Tosovsky who was in an advantageous position at the point when his concept received support in the Government from the ODS (which, according to its statements, nevertheless, stood against the breaching of the territorial limits, although not finding any problems in principle with coal itself) as well as the CSSD (which was rather inclined to the breaching but under the condition it was decided on in a referendum), while the Green Party - following the departure of Minister of the Environment, J. Dusik (the Green Party) and his replacement by Rut Bizkova (ODS, formerly employed at the Ministry of Industry and Trade) - did not have a lot of options to influence the concept's final approval.

\subsubsection{The Most Recent Developments Concerning the Strategic Documents}

The Minister of Industry and Trade, Martin Kocourek, also strove to replace the Concept from 2010 with his own version, but his early departure from the post, however, led to the withdrawal of this revision even before its complete release. For now the last discussed document was the revision proposed by Minister Martin Kuba from 2011. This version works with a 2060 time reference, placing the development of the Czech nuclear industry at heart of the paper. During the preparation period, however, the text had been undergoing the review and comment procedure by the Ministry of the Environment. 


\subsubsection{Conclusion}

The whole issue of the legal delimitation of the energy sector requires one more note. The strategic concept (policy) is in the ideal scenario supposed to set the basic state limits and priorities, which would leave a trace in every newly prepared law and in the overall position of the governmental apparatus while regulating this sector. As far as the previously described documents are concerned, this idea is to a certain degree lagging behind - albeit the State Energy Concept at least in some of the issues does indicate the Government's stance (usually when referring to the limits of coal mining), however, their real concord with the energy sector is generally rather poor. Usually, one cannot feel their bond with either of the governing parties of the coalition, let alone their hypothetical compliance with the opposition and potential to outlive more than one Government in an unchanged form. Instead of setting the direction for decades ahead, which would give coordination to the public and commercial sphere and which would present a reliable guideline for investors in their efforts to rationally allocate their assets, these sorts of document, on the contrary, rather serve as the presentation of the current distribution of opinions and powers in the Government. 



\section{Chapter 2: The History of the Czech Energy Sector ${ }^{18}$}

Filip Černoch

The development of the Czech energy sector has shown two basic trends after 1989. In the first place, it was the need to replace the previous system of a fully controlled and centrally run energy sector ${ }^{19}$ growing direct ties with Eastern bloc countries through a system reflecting the geopolitical, political and economic interests of a newly emerging state. This meant the need to privatize and liberalize the sector, to reduce its entire energy demand and find a way to efficiency, restructuring of an environmentally unsatisfactory coal sector and reduction of disproportionally high energy spending in households.

The second fundamental factor influencing developments in the sector was the EC/EU accession process for the Czech Republic, successfully completed in 2004. As part of that process, the Czech Republic had been adjusting to the energy legal framework and provisions of the acquis communautaire, which had primarily left a mark on acts addressing environmental issues, market liberalization and control of monopolistic behaviour or those acts treating the issue of state energy reserves.

In the upcoming chapter we will consider this course of development as well as try to capture some of the basic problems which the current Czech energy sector is encountering and which will likely remain relevant in the immediate future.

\subsection{The Thee Periods of Development from 1989 to Today}

The post-revolutionary development of the Czech energy sector and energy policy can in principle be divided into three basic phases. The first, which lasted roughly to the mid-1990s, led to the restructuring of the centrally run energy system and its division into a number of smaller entities, often still remaining in state hands. The second phase then involved privatization of the key energy companies, which registered the greatest success mainly in the gas sector. As a response to EU demands, in this phase came the initial steps of market liberalization, with the goal of customers being able to choose an electricity or natural gas supplier. The third phase, starting roughly in 2005 and lasting up to today, involves a stable situation where privatization has been brought to an end and the focus is primarily on completion of energy market liberalization, further harmonization with the EU requirements and maintenance of the energy sector in a decent shape for the future.

In parallel with these key processes, naturally, continuous modification of the entire line of further fundamental fields had been taking place - energetically demanding character of the energy sector in terms of the volume of primary materials spent per GDP unit had been significantly reduced. At that time the energy demand of the Czech economy was two to three times higher than in the rest of the EU. After a lot

18 The chapter in some of its parts makes direct reference to the text Energy Policy, published in the book Public Policy in the Czech Republic in the Years 1989-2009 (see Černoch, 2010, p. 141-167).

19 The energy industry and energy sector are for purposes of this text understood mainly as the electric power industry, gas and heat supply sectors, to a relevant extent also comprising of the coal industry and mining, as well as, peripherally, the processing of uranium ore. The Czech Republic has a very limited volume of its own oil and natural gas, which is why these sectors will be addressed only if they have influenced or are currently influencing the Czech energy industry as a whole. 
of delays as a result of insufficient political will ${ }^{20}$ and limited means, a trend towards energy production with cleaner, more modern and environmentally less damaging tools was set in motion. Once the position of the Russian Federation as practically the exclusive supplier of energy materials to the Czech Republic was weakened, one could also notice a particular advance in terms of Czech geopolitical security by, for example, building the IKL pipeline. The solution of problems associated with the restructuring of the coal sector then acquired a social dimension, since the former had led to a reduction of mining, the shutting down of mines and the dismissal of miners and workers in related professions. ${ }^{21}$ Two blocks of the second Czech nuclear power plant (Temelin) were built, and further projects are already in preparation.

\subsection{The Phase of Restructuring}

At the beginning of the 1990s the energy sector of the Czech Republic faced a major task. This was to shift the centralized, office-directed, energy inefficient, polluting and geopolitically one-sidedly dependent energy sector to Western European type energy sector, which the Czech Republic wished to join. The first step of this endeavour was the restructuring of the production and transmission structures of energy companies. The change affected approximately fifty state companies active in the field of fuel and energy systems, which were transformed into joint stock enterprises.

Already in 1990 electricity distribution was divided from its production, with eight regional energy distribution companies, or REAS, being separated from $\mathrm{CEZ}^{22}$, while the state kept a majority stake in them, as well as in the parent company. ${ }^{23} \mathrm{CEZ}$ from that point controlled only large power plants, some heating plants and the $400 \mathrm{kV}$ and $220 \mathrm{kV}$ transmission systems ${ }^{24}$ Over time, the heating supply companies separated from CEZ were privatised (with majority shares in the municipalities' possession), as well as research institutes, construction-assembling organizations and some smaller power plants.

Privatisation and restructuring in the coal sector was accompanied by notable social involvement by the state, since the programmed reduction of coal use and its replacement with natural gas understandably led to a reduction of mining and subsequent redundancies. As part of the modification of the entire sector in order to reach acceptable environmental standards, by 1998 the coal power plants were desulphurised (in some cases shut down) (see Píha, 1998, p. 236-237).

The monopoly importer, transporter and distributor of natural gas and other pipelined gases, CPP ${ }^{25}$, was as of January 1, 1994, restructured, leading to the separation of eight distribution companies with sig-

20 For example the position of the former Minister of Industry and Trade in the period 1998-2002, Miroslav Gregr, can be a typical illustration here, emphasizing the use of nuclear fuel and domestic coal with an attitude verging on the disdainful towards investment into cost-saving technologies or renewable sources.

21 To complete the picture, between 1990 and 2000, mining experienced a decline of $35 \%$, or 50.4 million tonnes per year in the case of brown coal, while in case of bituminous coal this reduction was from 23.3 million to 14.9 million tonnes per year. On the other hand, labour productivity had lifted from 325 to 630 extracted tonnes per person per year for bituminous coal (in the same period), and for brown coal from 1,930 to 3,256 tonnes per person (also in the same period) (see Energetické hospodářství ČR v analýze MPO, 2003).

22 Czech Power Works, previously Czechoslovakian Power Works.

23 Prazska energeticka, a. s., Stredoceska energeticka, a. s., Jihoceska energetika, a. s., Zapadoceska energetika, a. s., Vychodoceska energetika, a. s., Jihomoravska energetika, a. s., Severomoravska energetika, a. s.

24 The transmission system and the central dispatch were separated already in 1999 and joined to CEPS, however, still remaining in CEZ's ownership (see Píha, 1998, p. 236-237).

25 Czech Gas Company. 
nificant shares in the hands of cities, municipalities, and the state. The transition system, a spinal pipeline network, underground gas tanks and dispatch remained in the state's ownership in the form of a re-established company CPP Transgas (see Energetické hospodářství České republiky, 1999, p. 351).

Direct state financial expenditures in the energy sector were gradually stopped. State subsidies were concluded and the operation of energy companies was from that point on financed only from their own assets and bank loans. The latter, of course, caused pressure for increasing electricity prices, which until that time had been kept artificially at a very low level. It had been set by the Ministry of Finance and did not correspond either to the production or transmission expenses, not to mention the corresponding profits. ${ }^{26}$ Moreover, the subsidies for solid fuels were cancelled in 1994, liquid fuels in 1997 and thermal energy in 1998 (see Česká energetika na začátku roku 1995, 1995, p. 1-2).

The whole of this introductory process of restructuring and (limited) privatization passed without any significant turbulence, while a signal of confirmation of its minimum technical success came from the parallel connection of the Czech power system to the systems of Western Europe. That certainly does not mean that it all proceeded smoothly - for example, the newly emerged joint stock companies replicated the former state companies in terms of their structure and invested insufficient effort in their restructuring. By doing this, they kept the whole energy economy at an inefficient level, using the technologies and approaches of a highly energy-demanding character (see Energetické hospodářství České republiky, 1999, p. 350).

In this initial transformation phase, they also did not avoid the privatization difficulties inherent in the overall transformation of a post-revolutionary economy, where the sale of state property to the private entities in a number of cases lacked transparency, in parallel also not managing to achieve a stable and on a long-term basis, satisfactory form. This was naturally a matter of predominantly the larger energy entities, whose privatization had to be postponed for later.

'Demonopolisation' of the whole sector was also delayed, preceded by the planned privatization. Based on a Government Decree from spring 1992, CEZ was, for example, meant to be 'demonopolised' no later than during the second privatization wave, which did not happen. Therefore, CEPS, running the spinal network of the transmission system, remained in the ownership of CEZ even after its accounting independence in 1999. It was exactly the electric power sector that witnessed the emergence of an oligopolistic structure with a dominant company at its head, where a financially more efficient giant, i.e. CEZ, decides prices and the smaller producers are forced to adjust (see Invicta Bohemica, p. 18).

26 Criticism also came from representatives of the World Bank, which made a loan to the Czech Republic conditional on terminating this situation. The complete liberalisation of prices occurred at the beginning of the $2000 \mathrm{~s}$. 


\subsection{The Phase of Privatisation}

As previously mentioned, the most visible feature of the second phase of the post-revolutionary development of the Czech energy sector was the privatization of state shares, mainly in the great energy companies. This delicate process, realisation of which in the case of the electric power sector and petrochemicals proceeded without much transparency and in a disputable atmosphere, was additionally burdened by EU liberalisation demands in the second half of the 1990s. The whole this period was for this reason characterised by an interesting clash of two opposite processes, where the gas sector is observed through the lenses of successful privatization but delayed liberalization, and on the contrary, unmanaged privatization but realistic and quite fast liberalization took place in the electric power sector (see Výlupek, 2003).

The Government aimed at the completion of privatization basically all in one stroke, at the end of 2001. The state at that time still held a $67 \%$ share in CEZ as well as in single REAS (it had a majority share in five of them, while in PRE, JCE and JME a minority share) and a $97 \%$ share in Transgas, where in addition to the majority share in six regional distributors it had a majority share in PRP and JCP. The whole Unipetrol holding, including Chemopetrol Litvinov, Kaucuk Kralupy and Synthesie, was to be sold (see Invicta Bohemica, p. 18).

The political sensitivity of the entire sector led to a situation in which the Government, aside from the criteria of price, had set an entire line of limitations for applicants, in that manner expressing concerns regarding the strategic, security and social impacts of privatization. The future owners had to agree to a ban on the resale of purchased assets for a longer period, a change in the companies' structure was supposed to be possible only with the Government's agreement, and conditions dealing with the production maintenance of some power plants or requiring the consumption of brown coal were also mandatory. Such an approach, naturally, had its own impact on the price of the offered shares and the number of interested parties (see Invicta Bohemica, p. 18-19).

\subsubsection{Unipetrol}

The privatization of Unipetrol was essentially complicated by the Government's binding the new owner of this not too heterogeneous holding not to sell any of its parts in the course of the first ten years. Of the three interested parties which finally decided to enter the competition, the Austrian-Hungarian coalition OMV-MOL-TVK was not admitted to the envelope opening for formal reasons. For that reason, only the offers from the company Agrofert of Czech entrepreneur Andrej Babis, supported by the American company Conoco, and the British Rotch Energy, disadvantaged by its lack of greater experience in the petrochemicals field. Although the offers worked in favour of the latter, which was willing to pay 453 million EUR for the holding, in comparison to Agrofert's 361 million EUR, it was the Czech company that was finally chosen. A disputable clarification was that Agrofert is the greatest taxpayer in the Czech Republic, whereas Rotch Energy is just a mere speculator and not a strategic partner (see Invicta Bohemica, p. 19).

The problems related to Unipetrol's privatization however persisted. On September 30, 2003, Agrofert announced that, due to changes in circumstances which had an impact on its ability to meet the privatization requirements, it would not buy the share in Unipetrol and asked to negotiate a lower price and to change its strategic partner to the Polish PKN Orlen. Spidla's government for that reason decided to cancel the agreement and to start a new privatization round. 
The new round was at the end of 2003 joined by the abovementioned PKN Orlen, again in cooperation with Agrofert, as well as Conoco, then Hungarian MOL and British-Dutch Shell. The first applicant, although in collaboration with the already once problematic Agrofert, ${ }^{27}$ then truly obtained the state share for 14.7 billion CZK. ${ }^{28}$

\subsubsection{CEZ}

The privatization of CEZ was no less complicated. The Government was ideally looking forward to 300 billion CZK from its sale ${ }^{29}$, a great sum of money, at least with respect to the conditions such as a fifteen-year obligated take-off of brown coal and the requirement to keep a minimum share of electricity production from nuclear sources. ${ }^{30}$ Given the nature of the target company, practically all the important electric power companies in Europe joined the contest. The unambiguous favourite was the French monopolist and the strongest electric power company in Europe, Electricite de France, with vast experience in the nuclear industry.

The German companies RWE and E.ON proved to have quite strong potential as well, the weak point of the former was, however, its agreement with the German government to terminate the nuclear program, while E.ON was, unofficially, handicapped by the previous decision to stop exporting the Czech electricity to Germany. The British International Power (then owner of the Opatovice power plant) and British Energy allegedly also had modest chances. The American companies AES, NRG and Energy Corp. were with their offers of marginal importance, while the greater chances were not given either to the German-French EnBW, Italian Enel, Spanish Union Fenosa and Belgian Electrabel (see Zajíček, 2001b, p. 8).

Already during the preparation of the list of companies eligible to even enter the tender, a very surprising order of events took place. It was only EdF, Electrabel, the consortium of Enel and Iberdrola and the consortium of International Power and NRG that were eligible to submit offers.

The process of privatization proceeded in a similarly unclear manner also during the submitting of envelopes itself. EdF eliminated itself in a very unclear manner, as its representatives stayed too long in the canteen of the National Property Fund and by a couple of minutes missed the set time limit, and its offer encompassed a significant number of conditions in the case of the potential purchase. The British International Power was also eliminated for not meeting the formal requirements, moreover, abandoned by its American partner NRG due to the awkward situation on the domestic market. The subsequent support

27 The Partnership of PKN Orlen and Agrofert in the end terminated with a number of court proceedings exactly concerning ownership issues related to Unipetrol.

28 Already at the end of 2005, Unipetrol's privatization, however, erupted into a scandal with international reach, related to the suspicion of corruption both on the Polish and Czech sides. Locally the key moment was TV Nova's news report which videoed the meeting of the Head of the Prime Minister's Office (then Jiri Paroubek's office), Zdenek Dolezal with the Polish lobbyist Jacek Spyra, where Dolezal allegedly asked for a five million bribe for privatization in PKN Orlen's favour (see "Spory podnikatele Andreje Babiše").

29 See, for example, the statement of the then Deputy Minister of Industry and Trade, Zdenek Vorlicka: "If you take a look at the yearly profit of the Czech energy sector, then the sum of, for example, 300 billion CZK would not seem that much" (see Zajíček, 2001a, p. 12).

30 Next to the highest offered price, further terms which the Government set for privatization were not officially released and they ended up in the media only as a result of a leak. The Ekonom Weekly, for example, informed about the requirement to take a yearly amount of 27.74 million tonnes of brown coal from Northern and Western Bohemia for fifteen years and the condition to produce yearly at least 50.8 terawatt hours of electricity for CEZ in the years 2005-2012. There was, moreover, the possibility of imposing a fine in the amount up to $100 \%$ of the purchase price (see Geussová, 2001a, p. 17). 
of E.ON and British Energy proved to be insufficient substitution, and they were not individually called to submit their offers. Enel submitted an offer independently as well, while the last participant, the company Electrabel, resigned on its own initiative on the pretext of the non-transparent tender. Given the set terms, it was not surprising that the only unproblematic offer (EdF) proposed, in the Government's terms, a very low price of 135 billion CZK, which is why the Ministry of Industry and Trade invalidated the entire tender.

"After the first unsuccessful round of the privatization of the electricity sector, in December 2001 there was already a second try. Although it was clear that the conditions accompanying this sale were very strict and restricted the investor for a number of years, not only did the Government not compromise on them, but it insisted on a minimum price of 200 billion CZK - for CEZ, including the transmission system and six transmission companies" (see Geussová, 2002, p. 18). The Government in that manner invited only two companies into the new round, Enel and EdF, while establishing the abovementioned price of 200 billion CZK. These actors were willing to accept this figure only under the condition of a notable loosening of terms, which the Government rejected, once more bringing the privatization to an unsuccessful end (see Geussová, 2002, p. 18).

It seems very hard to judge the process of the whole privatization in an at least moderately optimistic tone. During its realization, the Government was seeking to reach several goals at once, starting from sustained operations, employment in the energy sector and socially beneficial activities, protection of "the national silver" before unwanted foreign buyers, through to insistence on the maximum price. All of that, moreover, spiced up with the tender's lack of transparency, selective choosing of which companies could enter the tender and a lack of understanding of the true value of the energy property, at the given point led to the collapse of the whole sale and to losing the trust of foreign investors that there was the capability or even willingness of the state to sell CEZ in a principled manner.

The complicated situation was finally solved at the local level, following the realization of the idea proposed (mainly) by Minister of Industry and Trade, Miroslav Gregr, of forming a strong energy entity following the example of France's EdF. Following the unsuccessful privatization, Zeman's government, offered to CEZ to buy its shares in REAS in exchange for a 2/3 share in the Czech transmission system.

During 2002 this proposal was, however, interrupted by the Office for the Protection of Competition, which thwarted the plan to form an energy monopoly. The whole transaction was limited by several conditions. In the first place, it ordered CEZ to get rid of shares in REAS in which it had a minority share (Prazska, Jihoceska and Jihomoravska energetika) and in one in which it had a majority stake. Instead of control of the entire distribution, the company was meant to maintain the control of only four REAS. The Anti-Monopoly Office decided on the need to also sell the remaining $34 \%$ of CEPS stocks held by CEZ, albeit it did not forbid its takeover by the state. ${ }^{31}$

Instead of the original scenario according to which CEZ was intended to obtain a strong European partner which would present a warranty of the company's success on the European market, the consolidated company in the end gained the potential to become a distinctive European actor on its own. On the other hand, the then Government in that manner resigned on the quick and efficient liberalization of the Czech electricity sector and at its heart left a very strong structure which for end users (at least according to some experts) meant a higher electricity price and other negative outcomes inherent in a monopolistic

31 A certain discomfort was also aroused in the aftermath of deciding the single traded companies' prices, which the Government commissioned from the only judicial expert (sic) during a three-week period. Economist Miroslav Zajicek in that context warned that, while the German group E.ON was willing to pay 22 thousand CZK for one share of Zapadoceska energetika half a year before the transaction itself, the mentioned expert valued them at 6,180 CZK per share, in that manner directing the execution of the sale between the state and CEZ (see Zajíček, 2002b, p. 9). 
market. "We can call it a Czech EdF", was a frank delineation of the situation by Minister of Industry and Trade, Milan Urban, in 2003, by which he quite unambiguously revealed the Government s priorities (see Zlámalová, 2003a, p. 9). The company's position was then confirmed also by the new verdict of the Anti-Monopoly Office from 2005, according to which the company could keep an interest also in one desired distribution company ${ }^{32}$ in which it had a majority share (see ČEZ, a. s., 2005).

\subsubsection{Transgas}

The privatization of Transgas and the gas distribution companies, on the other hand, proceeded in a much better way. A simpler ownership structure proved to be a great advantage, where the state had full control of Transgas and six out of the eight distribution companies (all except Jihoceska plynarenska, owned by E.ON, and Prazska plynarenska, controlled by the municipality of Prague, including a minority state interest), so it was unnecessary to deal with the minority shareholders.

Six companies had immediately shown an interest in Transgas, among them the consortium of RWE Gas/Wintershall as favourite, already then having a share in, for example, Prazska plynarenska (RWE) and Stredoceska and Severoceska plynareska (Wintershall). The German E.ON did not have as good a position, holding the stakes in Jihoceska, Zapadoceska and Jihomoravska plynarenska and generally striving to prominently expand into the Czech Republic (in the end joining the contest together with Duke Energy). SNAM/Ruhrgas/Gaz de France were interesting candidates, bringing into the competition a mixture of German and French ownership. The black sheep of the privatization was the Czech-Russian Gaz-Invest sponsored by Gazprom. Italian companies were presented by Edison Gas, the second largest gas company, while Duke Energy was the American representative (see Zajíček, 2001c, p. 9).

It was primarily the French who entered the tender with confidence: "Gaz de France and Ruhrgas already today use the networks of Transgas, and the members of consortium wish to strengthen the position of the Czech Republic as the European gas intersection", was, for example, the comment of Jean-Luc Demanesse, the head of the GdF Branch in Prague (see Bautzová, 2001, p. 14).

The tender was quite surprisingly won by the rather underrated RWE, as it offered by far the highest price of 133 billion CZK; it was a figure exceeding the Government's expectations of around 100 billion CZK. "With this increase by more than four million additional end users, RWE will become number four in the European gas market", was how Chairman of the RWE Board, Dietmar Kuhnt, justified the offered amount.

\subsubsection{Privatization of the Coal Sector}

A separate and rather complex chapter is devoted to the change of ownership structures in the Czech coal companies. The bituminous coal OKD, a. s. and three brown coal companies: Mostecka uhelna spolecnost (today a member of Czech Coal Group), Severoceske doly, a. s. and Sokolovská uhelná, a. s. were and are the largest companies of their kind.

If we start with the first mentioned company, the former state enterprise Ostravsko-karvinske doly was on January 21, 1991, replaced by a joint stock company of the same name, with a hundred per cent state share (see OKD, n.d.a). In 1997, the Government was preparing privatization of this company togeth-

32 It was Severoceska energetika, which was initially to be sold. 
er with its abovementioned brown coal colleagues. According to the initial proposals, a maximum $3 \%$ of OKD was supposed to be sold to the management of the company, another $34 \%$ to the strategic investor, while the remaining share was supposed to be sold on the stock market.

However, already during the preparation stage of trading it turned out that the state had during the 1990s lost a part of its control over the company, while the Investment and Post Bank had at the time collected roughly a fifth of the shares for an unspecified investor (see Privatizace hnědouhelných firem). At the beginning of the following year, it came to a direct clash between the state and the company it controlled, when the National Property Fund, which was responsible for the state shares in the company, accused the company's management of damaging the company's interests. "...the Fund has a serious suspicion that the management places the significant orders with associated companies and behaves more than a little oddly", observed the spokesman of FNM, Milos Ruzicka, concerning stock investments into Moravoslezske teplarny and Teplarny Karvina (see FNM bojuje s důlními giganty).

Only at the general meeting of the company at the turn of April and May 1998 did the state representatives finally reveal that they had practically lost the control over the company. The case was that an approximately $46 \%$ share was insufficient in comparison to a $46.3 \%$ share held together by the Bank Holding from IPB Group and the brokerage company Eurobrokers (see Němeček, 1998, p. 6).

A reminder of what was going on in the company in 1998 and 1999 can be found in the short summary published in the weekly Respekt in 2003, related to the charge levelled at the owners and managers of OKD, Viktor Kolacek and Petr Otava. "Ostravsko-karvinske doly had bought from Kolacek and Otava their private company K.O.P. for 3.9 billion CZK, which is in the experts' opinion an exaggerated sum. This is, for that matter, confirmed also by step number two: as soon as Kolacek and Otava had this money on the account, they had through a mediator bought a decisive package of OKD stock for 2.4 billion CZK and here escaped the Government. The whole transaction was completed by the new coal barons by sending the remaining 1.5 billion $\mathrm{CZK}$ - apparently commission - to the account of the mediator of the whole transaction, the secret Cypriot company Lagur Trading. In economic terms, the whole business, of course, does not make any sense: OKD first buys a private company for almost 4 billion CZK and afterwards allows its owners to seize control over it for a mere 2.4 billion?" (See Bártek, 2003a, p. 8).

The situation did not settle down completely even after this transaction. Attention was raised, for example, by the fact that immediately after seizing control over the mines, the company Karbon, owned by the above-mentioned managers, closed an advisory agreement with OKD, on which basis the former received roughly a half a million CZK per year. "The difference between the real expenses for providing the mentioned services and the sum Karbon Invest had siphoned off thanks to these contracts from 1999 with OKD and Ceskomoravsky doly, goes beyond the figure of 1.6 billion CZK", was the comment on the possible damage state prosecutor Karel Kalda, who was running the criminal proceedings (see Bártek, 2003b, p. 8).

The whole saga then continued in 2004, when the state sold its entire $46 \%$ OKD share to the dominant owner Karbon Invest, which in turn sold this share to the Cypriot RPG Industries owned by financier Zdenek Bakala (see Pokorný, 2004, p. 12). What seems interesting here is the price, since the then Government, despite higher offers, such as Penta's, sold its share for 4.1 billion CZK, which was then purchased from Karbon Invest by the previously mentioned Zdenek Bakala, according to estimates, for 12.5 billion CZK (see Zajíček, 2005, p. 8). 
In 2009, the Regional Court of Justice in Hradec Kralove released Viktor Kolacek, Petr Otava and (according to the prosecution) their co-offender Jan Przybyl.

The transfer of Mostecka uhelna's (MUS) property proceeded in a similarly interesting manner. The company emerged in November 1993 by unification of the former state enterprises Doly and Komorany preparation plants, Doly Lezaky and Doly Hlubina. A majority stake in MUS was then privatized during the second wave of privatization, while the state kept a minority share.

The privatization was meant to be completed by the end of 1997, again with the anticipated sale of a maximum $3 \%$ to the management of the company and $34 \%$ to the strategic investor (see Privatizace hnědouhelných firem).

Things, however, did not significantly change before the spring of 1998, when, as in the case of the previously mentioned OKD, the National Property Fund wished to call an extraordinary general meeting and check the economic activities of the company. ${ }^{33}$ The latter, however, only proved that the role of state is rather limited in the further running of the company. In an effort to dismiss the MUS Board for alleged opaque economic activities, it proved that the company was controlled by the anonymous group Investenergy located in Switzerland, while the actual owner was the American Appian Group (see Marek, Zlémalová, Fiala, 1998, p. 14).

The state at that point had only $46.29 \%$ of company's stock at its disposal. Accordingly, the suspicion that it was precisely the company's management that was struggling to seize the control over it grew stronger. "Our suspicion that the management is associated with the new investors is confirmed", declared spokesman of the FNM Milos Ruzicka after the general meeting (see Marek, Zlémalová, Fiala, 1998, p. 14). The transfer was then completed by the Ministry of Industry and Trade, which in May 1999 came to agreement with Appian Group concerning the sale of the state's share in MUS (see Americká skupina Appian koupí státní podíl). The company with its never revealed ownership structure in that manner took complete control over the greatest Czech producer of brown coal. Appian then in 2005 sold MUS to four managers of the company, namely to Antonin Kolacek, Lubos Mekota, Vasil Bobel and Petr Pudil (see Hudema, 2005, p. 3).

The extent to which the mentioned members of the company's management took part in the previously described property transactions is evidenced by events at the end of 2011. Under media pressure, Petr Necas' Government at that point dropped its approximately eighteen-months-long disinterest and decided to join the legal action initiated by the Swiss public prosecutor against the MUS management related to money laundering. The prosecution's materials in fact quite plainly described the order of events leading to the change of ownership in the company.

"According to the prosecution, the managers of MUS from December 1996 to June 1998 misappropriated more than two and a half billion CZK from the company's account, which they were administering. In the second phase, from December 1998 to April 2002, the managers, later also the owners of MUS, misappropriated another four and a half billion CZK."

33 The server Ceskapozice.cz in 2011 released an interesting document, in which the representatives of FNM management just before the mentioned general meeting had warned the relevant people, i.e. Minister of Finance Ivan Pilip, the head of the Industry and Trade resort, Karel Kuhnl and the bodies involved in the criminal proceedings. Already the first lines of the document were interesting: "In 1998, the National Property Fund of the Czech Republic obtained information which led to suspicion that the members of Mostecke uhelna company's management were involved in activities that met the definition of the crime of information abuse during trading, breach of obligations during the management of another's property, potentially also the crime of fraud". This information referred to both the "tunnelling" of MUS and its "hostile takeover" (see Léko, 2011b). 
The managers used the first two and a half billion CZK for a very thought-through and in the greatest secrecy executed purchase of stocks in an amount that, for the money they stole, they gained a $50 \%$ share in the state strategic company... According to the prosecution, the managers immediately afterwards misappropriated another four and a half billion CZK. They used a part of that sum to return the money from the first misappropriation. The other part, specifically six hundred and fifty million CZK, went to the fraudulent and corrupt purchase of MUS stock from the Czech state, to which they, according to the prosecution, paid three and a half million less than its real value. The managers then sent a hundred and fifty million CZK to an account which friends of the former CSSD deputies Stanislav Gross, Pavel Musela and Jiri Martinek had access to - the Government, which approved the state, sale was in the CSSD's hands. And finally, they sent a bit less than a million and a half to their private accounts," is how the weekly Respekt summed up the main points of the case (see Spurný, Kundra, 2011). After merging with Severoceska uhelna, a. s., the company then in 2005 changed its name to Mostecka uhelna, a. s., and in 2008 to Czech Coal Services, a. s. Furthermore, in 2006 the investor Pavel Tykac entered the company, while the former owners (Antonin Kolacek, Lubos Mekota) left.

At the time of writing, it was unclear where the situation would lead, while what could prove problematic is the that, due to the delayed reaction of the Czech side, the statute of limitations might have lapsed (see Pokorný, 2011).

Sokolovska uhelna, a. s., emerged in 1994 by the merging of Palivovy kombinat Vresova, Hnedohelne doly Brezova and Rekultivace Sokolov (see SUAS, n.d.). It had the same destiny as its larger colleagues - the sale of a small stake to the management, $34 \%$ to the strategic investor and the remainder on the stock exchange. The state prevented a repeat of the OKD and MUS scenarios by enhancing its previous minority stake in the company by buying additional $1.3 \%$ of the shares, by which it obtained a $50 \%$ stake (see Žák, 2003, p. 6). There was, however, no sign of privatization during the 1990s.

In 2003, the Financial Times referred to the anticipated completion of privatization in an article starting with the following words: "The Czech Government plans to privatize brown coal mines in the competition in which the majority of foreign applicants will be eliminated" (see Zlámalová, Němeček, 2003, p. 9). In an effort to keep potential German companies in check, ${ }^{34}$ from which the Government expected nothing less than limited mining and preference of local industry over Czech, it came to the narrowing down of possible investors practically into two groups - the company's managers themselves and the owners of OKD, Viktor Kolacek and Petr Otava. Through the company Metlimex, the latter two owned $36 \%$ of Sokolska uhelna's stock (see Bártek, 2003c, p. 8).

Kolacek and Otava's arrest and investigation then spiced up the situation, when the privatization commission eliminated all the other applicants and had the state sell the company to the management for approximately 2.6 billion CZK. This price was repeatedly criticized for being too low: "The price for the state share should be between 7 and 10 billion CZK", argued the analyst of Atlantik FT, Roman Cenek (see Pokorný, 2003, p. 8). This claim finds confirmation, for example, in the fact the company had 4 billion CZK only on accounts aimed at landscape recultivation, which it could have practically used until its eventual spending, while the offer of the American company Independent Power (over 6 billion CZK) or of the Slovakian investors Penta (over 7 billion CZK) should not be understated either. As previously said, the commission in charge for selection, nonetheless, eliminated both companies without providing them with any detailed explanation.

Severoceske doly, a. s., (SD), established by the merger of Doly Nastup Tusmice and Doly Bilina in 1994, had a somewhat different destiny. In terms of privatization, SD was meant to be taken over by a pri-

34 "A German mining company cannot be the investor for it would be bringing coal from Germany," are, for example, the words of Deputy Minister of Industry and Trade Martin Pecina (see Zlámalová, 2003b, p. 3). 
vate owner as in the case of Sokolovska uhelna, first through the process of privatization in the second half of the 1990s, and then through sale in 2003. Having the above discussed obstacles in mind, the expectations were, therefore, raised on the dominant offer of the company Appian Group (see the part devoted to Mostecka uhelna, a. s.). Only CEZ could have been serious competition as it was both the most important minority shareholder with $39 \%$ and the significant consumer of coal (SD covered $80 \%$ of CEZ's coal consumption). CEZ's offer finally was not accepted, which is often linked to the removal of the then head of CEZ, Jaroslav Mil, who was replaced by Martin Roman (see Zajíček, 2003, p. 8).

The tender, which the Czech and foreign media saw as highly opaque due to a number of restriction terms, an obscure selection process and speculation referring to the favouring of the Appian Group, finally received three offers. The Slovakian group Penta wished to buy SD for 5.3 billion CZK, J\&T offered 6.8 billion CZK and Appian Group 4.83 billion CZK (see Šafaříková, Němeček, 2003, p. 9). The Government then cancelled the tender. The final decision then was to resign from selling the mines through a tender and to execute a direct trade off with CEZ, which in 2005 bought for approximately 9 billion CZK another $37.31 \%$ of SD stocks and in that manner increased its stake to $93.1 \%$. The purchase of the remaining stock took place in the year after (see ČEZ, a. s., n.d.i.).

\subsubsection{Issues Related to Admission to the EU - Liberalization of the Energy Sector}

Let us take a closer look at the period after 1995, when the so called European Agreement entered into effect. The latter codified the entry of the Czech Republic into the EU, on the basis of which the Czech Republic was bound to adjust the local legal framework to the EU one in the course of ten years. Just for an idea, "the current [2008, author's note] analysis identified roughly a thousand secondary acts of communitarian law regulating the energy field (...) after deduction of legally unbinding acts and acts which are addressed only to some EU entities, we arrive at 150 regulations legally binding for the Czech Republic" (see Fousek, 1998, p. 4).

The Czech Republic's objectives in many aspects corresponded to EU requirements, albeit the accentuation and, before all, the planned pace of changes could have been somewhat different. Even without the incentives coming from Brussels, it would, of course, have come to movement towards the market economy, including the settlement of energy commodity prices and complete removal of state subsidies. It is the same case with the adjustment of the legislation, for example treating the functioning of private energy companies, delimiting the state role in the energy sector, for example in terms of preserving free competition and restricting monopolies, followed by the establishment and streamlining of the required control offices (ERU, State Energy Inspection). The energy sector had to go through changes leading to greater efficiency, greater conservation of raw materials and greater environmental awareness. Neither would the outdated coal sector escape the rebuilding. All of this would sooner or later have happened on its own, so every assessment report and other outcomes of the pre-accession negotiations rather served as observations on ongoing changes than as a way of imposing them.

There were actually truly few problematic issues. Rather as a matter of financial means as well as the adoption of necessary legislation, the requirement was laid to secure 90-day reserves of oil and oil equivalents in case a crisis arose. The latter was resolved by the Act on Emergency Oil Stocks 189/1999 Coll., which required a progressive increase in these reserves and led to the gradual resolution of the situation by $2005 .^{35}$ The transition period, which was extraordinarily arranged until December 31, 2005, was indeed

35 These reserves are provided by the Administration of State Mineral Reserves, which regularly submits reports on the state of these reserves to the European Commission. 
only a reserve for fine-tuning and not the Czech Republic's effort to unnecessarily prolong the whole issue. This is made apparent also by the Czech Republic's current effort to increase these reserves to 120 days, notably beyond the level requested by Directive 2006/67/EC (respectively from December 31, 2012 Directive 2009/119/EC) (see Černoch, Dančák, Kod’ousková, Leshchenko, Ocelík, Osička, Šebek, Vlček, \& Zapletalová, 2012).

\begin{tabular}{|l|l|l|l|}
\hline Tab. 2.1: The Process of Electricity Market Liberalization \\
\hline Period & $\begin{array}{l}\text { Eligible customers - customers enti- } \\
\text { tled to choose an electricity supplier } \\
\text { on their own }\end{array}$ & $\begin{array}{l}\text { Offers can be provided by } \\
\text { producers with a minimum } \\
\text { production exceeding }\end{array}$ & $\begin{array}{l}\text { \% of total } \\
\text { consumption }\end{array}$ \\
\hline From 2002 & $\begin{array}{l}\text { End users whose yearly electricity use } \\
\text { exceeds 40 GWh }\end{array}$ & $10 \mathrm{MW}$ & $17.9 \%$ \\
\hline From 2003 & $\begin{array}{l}\text { End users whose yearly electricity use } \\
\text { exceeds 9 GWh }\end{array}$ & Any production level & $29.8 \%$ \\
\hline From 2004 & $\begin{array}{l}\text { End users with continuous metering, } \\
\text { households excluded }\end{array}$ & Any production level & $47.4 \%$ \\
\hline From 2005 & All end users, households excluded & Any production level & $72 \%$ \\
\hline From 2006 & All end users & Any production level & $100 \%$ \\
\hline Source: ERÚ & & & \\
\hline
\end{tabular}

The requirements for solving market liberalization were far more complicated, primarily in terms of enabling customers to choose natural gas and electricity suppliers on their own. "On February 19 [1999, author's note], the energy monopoly in EU countries will end. A consumer will progressively be able to freely choose his or her own supplier, also from another country. Competition will start reducing prices ... a two-year preparation period came to an end, during which EU member states had to adjust to the principles of Directive No. 96/92, which regulates the requirement to loosen the energy monopoly. It had set up the liberalization process, which strong business lobbying groups initially forced on their governments..." (see Kučera, 1999, p. 38).

The arrival of these and similar texts in the Czech Republic gave rise to a debate over the liberalization of the domestic electricity and natural gas market, substantially drawing from the EU requirements. "Key elements of the energy acquis are Treaty [on EU, author's note] provisions and secondary legislation particularly concerning competition and state aid, and the internal energy market. Ongoing developments include liberalization of the gas sector..." (see Posudek komise k žádosti).

Liberalization at the EU level was generally stimulated by the Directive concerning common rules for the internal market in electricity No. 96/92/EC and the Directive concerning common rules for the internal 
market in natural gas No. 98/30/EC..$^{36}$ Both documents, among other things, required enabling third party access to the transmission electricity and natural gas networks which are of a natural monopolistic character. They, therefore, addressed the situation in which, for example, the power system operator is bound under defined circumstances to enable use of lines to the respective energy producers in a manner allowing an end user to choose between their offers.

\begin{tabular}{|l|l|}
\hline \multicolumn{2}{|l|}{ Tab. 2.2: Liberalization of the Natural Gas Market } \\
\hline Period & Eligible customers - the customers entitled to choose a gas supplier on their own \\
\hline From 2005 & $\begin{array}{l}\text { End users with consumption exceeding } 15 \mathrm{million} \mathrm{m}^{3} / \text { year per single consumption site } \\
\text { as well as all licensed electricity producers burning gas in thermal power plants or dur- } \\
\text { ing the combined production of electricity and heat. }\end{array}$ \\
\hline From 2006 & All end users, excluding households \\
\hline From 2007 & All customers, including households \\
\hline Source: ERÚ \\
\hline
\end{tabular}

Liberalization in the Czech Republic had started at a rather easy pace. The issue was first addressed by The Energy Act No. 222/1994 Coll., while the Government had a detailed timetable only with The Energy Act from 2000 (458/2000 Coll.). The latter also regulated other requirements included in EU directives, for example delimiting the authorization principle for building new energy capacities or the obligation to keep separate accounting across single activities.

EU liberalization requests were emphasized also in the new Directive 2003/54/EC concerning common rules for the internal market in electricity and Directive 2003/55/ concerning common rules for the internal market in natural gas, which the Czech Republic had also incorporated in its legislation and, in line with their aims, also speeded up the opening up of the whole market.

If we are to observe the liberalization development itself, it is apparent that the Czech Republic was not among the greatest proponents of this idea. This is apparent from the fact itself that it arranged with the European Commission to postpone the entering of respective directives into effect, meaning that complete market opening was supposed to happen in 2005 in the case of electricity, and in 2008 in the case of gas. ${ }^{37}$

36 These Directives are called the First Liberalization Package. They were, however, preceded by similarly tuned, but less ambitious acts such as the Draft Directive on Transparency of Consumer Energy Prices (COM89/123) and the Draft Directive on Natural Gas (COM89/334) and Electricity Transportation (COM89/336), Directive 90/547/EEC on the transit of electricity through transmission grids and Directive 91/296/EEC on the transit of natural gas through grids (see Černoch, 2011, p. 51-52).

37 In the end it did not take place before 2007. 


\begin{tabular}{|l|l|l|l|l|l|l|l|}
\hline \multicolumn{2}{|l|}{ Tab. 2.3: The Number of Electricity and Natural Gas Suppliers Changed During the Liberalization } \\
Process and After its Completion \\
\hline
\end{tabular}

The liberalization trend of the single EU energy market, of course, did not end with the Czech Republic's entry into the EU. The most recent incentives came with the adoption of the Third Liberalization Package, predominantly consisting of directives regulating the rules of the internal market in gas and electricity. The latter define different types of ownership unbundling of the transmission networks from producers, specifically, absolute ownership unbundling and two more moderate models. The whole package is then devoted also to the authorities of the regulatory organs and formation of its equivalent covering the whole EU (ACER) as well as the rights of end users.

These new features entered the Czech legal framework though the amendment to The Energy Act (Act No. 211/2011 Coll.) from August 18, 2011 (see Pravda, 2011, p. 39). The general character of this amendment is discussed in the other part of the book, we will here, however, cover only modifications concerning electricity and natural gas market liberalization.

The greatest innovation, the ownership unbundling of network operators from production and trade, referred only to the electricity industry, in other words to CEPS. The latter has been, already since 2011, an independent entity and has no ownership relations with the former parent company CEZ. ${ }^{38} \mathrm{As}$ far as the gas sector is concerned, the state intervened to ensure a looser modification of ownership relations through the means of the ITO (Independent Transmission Operator), where an operator of the transmission system and

38 CEPS, a. s., is in the $100 \%$ ownership of the Ministry of Industry and Trade, while the Ministry of Finance has a share in CEZ, a. s. 
a producer or supplier can remain in a joint concern, while being the subject of major regulation performed by the supervising organ (ERU) - either during the appointment of the company's management, preparation of investment plans or verification of the transmission system operator's independence. NET4GAS, as the operator of the core gas pipelines, in that manner had to remain a part of RWE (see Pravda, 2011, p. 39).

The situation in the gas sector has in the recent months been changing significantly and it seems that the debate over which regulation model to apply to NET4GAS has ceased to have much point. RWE Transgas, a part of the German RWE concern, has actually sold transit pipelines (see Kubátová, 2012). The reason is the need to consolidate the company and obtain the means for investments in Germany itself, related to the pressure imposed there on energy companies due to the countrys departure from nuclear energy. A consortium of the insurance company Allianz and Canadian investment company Borealis has become the new owner of NET4GAS, by which the latters (in)dependence on the initial parent company has become a matter of the past.

\subsubsection{Temelin}

We will at this point turn to one more issue, i.e. the Temelin nuclear power plant. Even though it is a partial problem, and therefore not of a systemic character, seeming not to deserve so much space within a chapter on history, the influence which the Temelin nuclear power plant has on the formation and development of the Czech energy sector means we cannot ignore it. We will not look at the importance which the Temelin nuclear power plant has for the energy mix or its technical performance, but rather in the circumstances of the power plant's completion, as one of the most delicate energy-related topics in the 1990s.

The decision to build the power plant came as early as 1980, with a planned four 1,000 megawatt VVER 1000 blocks. Two years later, a contract on supply of the Soviet technical project followed, while the construction permit was issued in November 1986. When construction was initiated in February 1987 (company Skoda Praha), it seemed that everything would proceed without greater complications all the way through to the launching of the power plant (see ČEZ, a. s., n.d.j.).

After November 1989, the project came to be modified, mainly after re-evaluating whether the Czech Republic needed such a massive power source and after calculating the cost. The Czech Government with Decree No. 103/93 from March 1993 considered building a mere two blocks, which in 2000 produced their first electricity, while in 2002 (the first block), respectively in 2003 (the second block) underwent test operation. They were launched with their full capacity in 2004. The power plant received final approval in 2006 (see ČEZ, a. s., n.d.j.).

This brief description, however, neglects the turbulent atmosphere which had lasted for more than a decade when construction was taking place. Temelin was raising powerful reactions both at local and foreign level, and its completion was more than once given second thoughts.

The first serious obstacles it had to face arrived immediately at the start of 1990s, when its opponents organized themselves within NGOs, such as South Bohemian Mothers against Atomic Danger. Demonstrations against completion were frequent, such as the one, for example, on April 27, 1991, which was also joined by the citizens of Germany and Austria (see Petrlík, 1991, p. 8).

During the same period the awkwardness of the Temelin issue was confirmed also by the decision of the government headed by Prime Minister Petr Pithart, who closed the question of Temelin's completion by leaving the final verdict to his successors. The two studies which emerged in 1992 made a contribution of their own; one commissioned by the Ministry for Economic Affairs and Development of the Czech Re- 
public and the other ordered from the American company Power International by unidentified government offices. Without going into detail, we can note that the studies were dramatically at odds with each other the one ordered by the Ministry argued that the completion of Temelin nuclear power plant was necessary if the country was to escape an energy collapse. Power International, on the contrary, saw the completion of the power plant as leading to a surplus of electricity and the need to close a significant amount of other energy capacity. A similar analysis was introduced also concerning the estimated electricity price, which was supposed to be $0.60 \mathrm{CZK}$ or even up to $2.40 \mathrm{CZK}$ (see Gruner, 1992, p. 5).

The further progress on the construction then continued in a similarly unpersuasive manner. Announcements of delays or rising prices were quite regular, until the intervention of the Government headed by Prime Minister Josef Tosovsky, which asked an independent commission to inspect the whole business. Its final report released a final price ranging around a level of at least 110 billion CZK, while the commission did not miss the opportunity to question the need for the Temelin nuclear power plant in the first place, in terms of expected energy consumption (see Hrubý, 1999; Švehla, 1999a, p. 6).

\section{Tab. 2.4: The Final Report of the Expert Team for an Independent Assessment of the Completion of the Temelin Nuclear Power Plant}

The report points out the inefficiency of investment into the Temelin nuclear power plant as a whole. Then it states that the completion of Temelin seems to be quite risky and that the non-completion of Temelin can be managed with less risk than any alternative based on Temelin's functioning. The decision on completion or non-completion cannot be, according to these experts, supported with unambiguous economic arguments for going for one or the other solution. Each solution will, according to them, have more negative than positive aspects. The agreements closed with the domestic suppliers and Westinghouse are basically perceived as disadvantageous for CEZ as the investor. The credibility of agreed schedules, moreover, for CEZ presents a business risk (prolongation of deadlines, rising expenses). Investment assets for the Temelin nuclear power plant and the production costs per electricity unit are far beyond the average when compared to foreign projects. The report also notes that outages ascribed to a lack of electricity as a result of the non-existence of the Temelin nuclear power plant can be dismissed. The situation after 2015 is being, however, undeclared, when the majority of existing coal will come to an end of their era. A parallel scenario of substituting the Temelin production with alternative energy sources would, moreover, contribute to a greater employment. The report ironically, despite the latter point, sees the completion of building as an option making an economic contribution. It nevertheless warns that a market (either in the Czech Republic or abroad) for electricity produced in Temelin should be found, else completion would render it uneconomic and unnecessary.

Source: Hrubý, 1999; prepared by P. Bendlová 


\section{Tab. 2.5: The Increasing Costs of Building the Temelin Nuclear Power Plant in 1993-1999 (billion CZK}

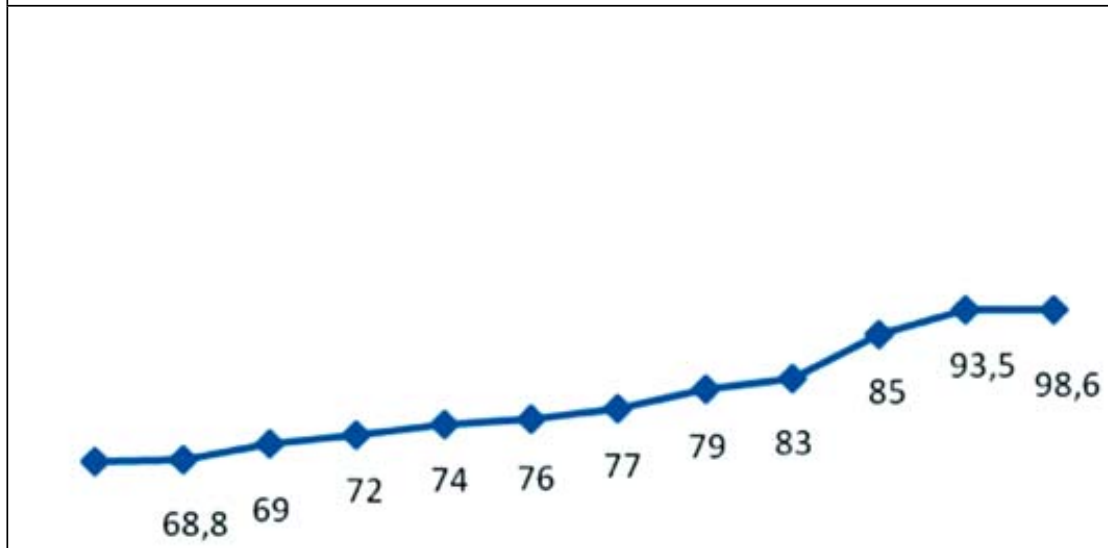

$\leadsto$ Cena...

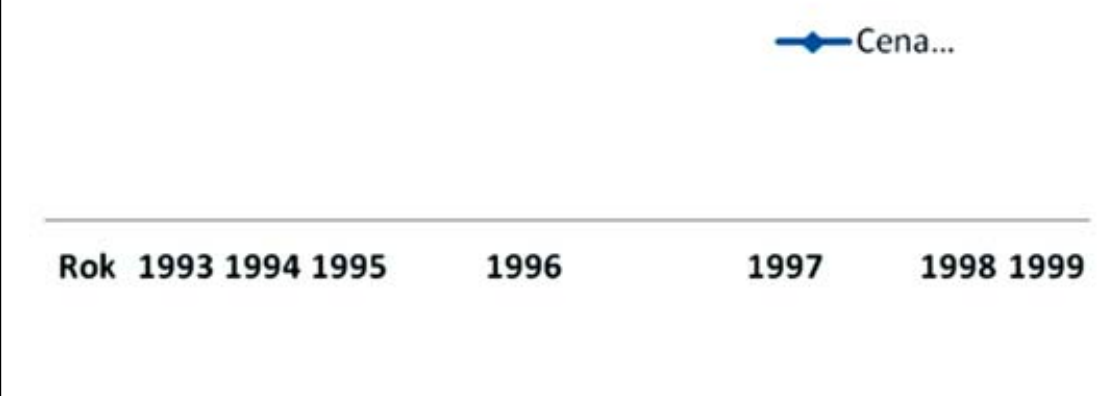

According to Government Decree No. 109 from 1993, the construction of two Temelin blocks was supposed to cost 68.8 billion CZK. During the delayed construction, not completed until 2000 (the Government originally planned commencement in 1995-1997), the price rose by almost 30 billion CZK, therefore, by approximately $43 \%$ of the original budget. This was a result of a change of technologies and documentation processing, change in the works' timetable, transformation of contractual relations, a change of cabling and Westinghouse's underestimates. The expense of changing technologies between 1991 and 1993 was also a part of the price.

Source: “Údaje o Temelínu,” n.d.; “Temelín - termín dostavby neznámý,” 1998; Sviták, 2010; prepared by P. Bendlová

In terms of the economic profitability of the whole power plant, it was said that the investments would return economically only if the power plant were to be completed in three years. Traditionally reserved towards Temelin, the weekly Respekt commented on the conclusions of the report with open sarcasm: "Throughout the year CEZ was providing us with two sorts of information. Firstly, that electricity from the nuclear power plant is absolutely the cheapest, and secondly, that the republic would break down in the aftermath of an energy collapse without this super-cheap electricity. Today marks the fourth year from when we were supposed to live in a country sunk in darkness, where trains do not run, factories stand still and hospitals are closed. This is how CEZ experts painted the future of the Czech Republic after 1995, if Temelin were not completed. The power plant is still not standing, but dark forecasts, nevertheless, have been proven wrong. (...) Together with postponing the date of completion, the energy lobby also pushed its prophesy of an energy emergency further off. In the mid-1990s, CEZ predicted it at the end of the decade, now in 2005 we will supposedly "make it" without Temelin" (see Švehla, 1999b, p. 5).

In any case, (already Zeman's) government decided to proceed with the unconditional completion of the Temelin nuclear power plant, where the major role was played by the convincing proponent of the project, Minister Gregr. "I do not believe the arguments that Temelin is unnecessary," commented one of completion's proponents, Minister of Interior Affairs, Vaclav Grulich. "After all, we need to get industry on its feet. And then it will be necessary" (see Švehla, 1999c, p. 4).

By this the last obstacle to completion fell and on November 3, 2006, with effect from November 6 of the same year, Temelin was supposed to be put to the test. 
At this point it would be appropriate to use yet more available information and decide what was actually true in the discussion over the completion of the whole power plant. Unfortunately, it is even with a certain distance in time impossible to provide an unambiguous answer. It is in the first place complicated by the problem's complexity itself - the lifespan of a nuclear power plant is estimated at several decades, therefore, posing the difficulty of calculating the return on investment even by using more sophisticated economic methods. Moreover, such a massive building to a particular extent influences the whole development of the Czech energy mix and, by the same token, in a specific manner adjusts its setting.

In parallel, a number of arguments are by their nature very hard to quantify; particularly the issue of the entire power plant's safety. The latter mainly depends on one's personal point of view. .... We will regardless try to at least comment on the most frequent arguments used during the debate.

Temelin nuclear power plant is not and, with respect to trends in electricity consumption, will not be necessary.

One of the key trumps of opponents was to challenge the need for Temelin itself with respect to the constant export of electricity from the Czech Republic. 


\begin{tabular}{|c|c|c|c|c|c|}
\hline \multicolumn{6}{|c|}{$\begin{array}{l}\text { Tab. 2.6: The Production and Export of Electricity in the Czech Republic from } 1989 \\
\text { [GWh gross/year] }\end{array}$} \\
\hline & $\begin{array}{l}\text { Electricity } \\
\text { produc- } \\
\text { tion in CR }\end{array}$ & $\begin{array}{l}\text { Net export } \\
\text { of electrici- } \\
\text { ty from CR }\end{array}$ & $\begin{array}{l}\text { Electricity } \\
\text { produc- } \\
\text { tion CEZ }\end{array}$ & $\begin{array}{l}\text { Electricity } \\
\text { production } \\
\text { Temelin }\end{array}$ & \multirow{24}{*}{$\begin{array}{l}\text { As displayed in the table, elec- } \\
\text { tricity production in the Czech } \\
\text { Republic from } 1989 \text { on average } \\
\text { has increased. It is interesting } \\
\text { that, while in } 1993-2001 \text { CEZ's } \\
\text { share of electricity production } \\
\text { out of total electricity production } \\
\text { in the Czech Republic (gross) de- } \\
\text { clined from almost } 79 \% \text { to less } \\
\text { than } 70 \% \text {, in } 2002-2007 \text { (when } \\
\text { Temelin was started up) it in- } \\
\text { creased to almost } 84 \% \text {, while it } \\
\text { in the forthcoming years again } \\
\text { started to moderately decrease } \\
\text { (to less than } 80 \% \text { in } 2010 \text { ), when } \\
\text { Temelin's completion was again } \\
\text { brought to the fore. } \\
\text { Temelin contributes to CEZ's } \\
\text { electricity production with an av- } \\
\text { erage share of } 19 \% \text {. } \\
\text { Temelin nuclear power plant on } \\
\text { average produces (during periods } \\
\text { of peak operation) } 12,448 \text { GWh } \\
\text { of electricity per year. In the } \\
\text { same period ( } 2004-2010 \text { ) net ex- } \\
\text { ports (export minus imports) of } \\
\text { electricity in the Czech Republic } \\
\text { on average amounted to } 13,885 \\
\text { GWh. We can, therefore, observe } \\
\text { that almost } 90 \% \text { of net exports } \\
\text { consist of an amount equivalent } \\
\text { to Temelin's entire production. }\end{array}$} \\
\hline 1989 & 65,132 & 2,783 & $\mathrm{x}$ & $X$ & \\
\hline 1990 & 62,558 & 692 & $\mathrm{x}$ & $X$ & \\
\hline 1991 & 60,528 & 2,530 & $\mathrm{x}$ & $X$ & \\
\hline 1992 & 59,293 & 3,036 & $\mathrm{x}$ & $X$ & \\
\hline 1993 & 58,882 & 2,104 & 46,455 & $\mathrm{X}$ & \\
\hline 1994 & 58,705 & 445 & 45,377 & $X$ & \\
\hline 1995 & 60,847 & -418 & 46,361 & $X$ & \\
\hline 1996 & 64,257 & 3 & 48,266 & $X$ & \\
\hline 1997 & 64,598 & 1,188 & 48,088 & $X$ & \\
\hline 1998 & 65,112 & 2,461 & 47,892 & $X$ & \\
\hline 1999 & 64,368 & 3,277 & 45,722 & $X$ & \\
\hline 2000 & 73,466 & 10,017 & 50,842 & 2 & \\
\hline 2001 & 74,647 & 9,539 & 52,162 & 1,156 & \\
\hline 2002 & 76,348 & 11,387 & 54,118 & 5,439 & \\
\hline 2003 & 83,226 & 16,213 & 61,399 & 12,117 & \\
\hline 2004 & 84,333 & 15,717 & 62,126 & 12,692 & \\
\hline 2005 & 82,579 & 12,634 & 60,016 & 10,984 & \\
\hline 2006 & 84,361 & 12,631 & 65,532 & 12,021 & \\
\hline 2007 & 88,198 & 16,153 & 73,793 & 12,265 & \\
\hline 2008 & 83,518 & 11,469 & 67,595 & 12,103 & \\
\hline 2009 & 82,250 & 13,644 & 65,344 & 13,250 & \\
\hline 2010 & 85,910 & 14,948 & 68,433 & 13,823 & \\
\hline \multicolumn{5}{|c|}{$\begin{array}{l}\text { x - the subject does not exist/does not produce electricity } \\
\text { Source: Sviták, 2010; Peterková, 2007, p. 5; Energetický regulační } \\
\text { úrad, 2011f; ČEZ, a. s., 2010c, p. 21; prepared by P. Bendlová }\end{array}$} & \\
\hline
\end{tabular}

"In 1998, CEZ, for example, declared that we could manage without electricity from the Temelin nuclear power plant until 2003, but then we would start to feel its absence. In 1999, it said that this would happen in 2005, while the analysis of the Temelin Commission noted that the new capacities would not be necessary before 2010", summarized the weekly Ekonom in 2000 (see Geussová, 2000a, p. 10). If we look at statistics, it shows that net exports of electricity from the Czech Republic constantly increase, and from 2003 even exceeds, sometimes only matching, the whole production of Temelin (see "Bilance elektrické energie"). 
In that context, the argument over the necessity of Temelin as a replacement for the closed down coalfired power plant blocks was also questionable, when CEZ had between 1991 and 1998 taken 2,020 MW of installed capacity out of operation (see 90. léta - program "vyčištění" uhelných zdrojů).

Tab. 2.7: CEZ Coal-Fired Power Plants - decommissioned capacity (reduction program of coal)

\begin{tabular}{|c|c|}
\hline Year & Decommissioned capacity [MW] \\
\hline 1991 & 320 \\
\hline 1992 & 320 \\
\hline 1993 & 55 \\
\hline 1994 & 310 \\
\hline 1995 & 50 \\
\hline 1996 & 160 \\
\hline 1997 & 0 \\
\hline 1998 & 905 \\
\hline Total & 2,120 \\
\hline
\end{tabular}

As part of the coal reduction program, CEZ had in 1991-1998 reduced installed capacity by 2,120 MW. For comparison, the Temelin nuclear power plant has 2,000 MW of installed capacity.

Source: ČEZ, a. s., n.d.h; modified by P. Bendlová

This argument was deployed in 1993, for example, by the then General Director of CEZ, Petr Karas: "We are not building Temelin for today, but approximately for 2000. In 1996, CEZ is bound to take out of operation all polluting energy sources... [Temelin] is not to add capacity to the system, but to substitute for those coal-fired power plants, which are being put out of operation" (see Wanke, 1993, p. 8).

It seems that the defenders of Temelin's completion went rather too far with their estimates and analysis at least concerning the assessment of demand and consumption of electricity in the Czech Republic. On the other hand, the key factor of nuclear plants was often understated, which is their major role in ensuring a base load ${ }^{39}$. Unlike coal and gas power plants which are more suitable for covering the demand for peak energy, nuclear power plants prove adequate exactly for delivering a stable, non-oscillating volume of electricity to the grid. In the whole debate focused on the necessity vs. dispensability of Temelin power plant, this argument was brought up only marginally.

\section{Profitability of Temelin Nuclear Power Plant}

"There is no reason to question the whole sum necessary to build the Temelin nuclear power plant, which is 68.8 billion CZK", responded the Head of CEZ's Press Department, Michal Kacena, in 2004 to objections of the Green Party regarding the increasing costs of this power plant (see ČEZ popírá, že Temelín bude dvakrát dražší). The final cost in the end rose to roughly $95-110$ billion CZK. ${ }^{40}$

39 See the chapter on the electric power industry.

40 The difference is caused by the fact that lower estimates do not include expenses such as interest on the loan for completion of the project. 
Deciding whether the construction will pay off is, however, overly complicated. The calculation also involves the changing market price of electricity, which is, with regard to Temelin's lifespan, extremely hard to estimate. Political pressures have their impact as well, for example, in terms of the financially demanding enhancement of safety, which was certainly brought into connection, for example, with the events following the accident at Fukushima. The traditional objection of Temelin's opponents is that the costs of the power plant are to a certain degree covered by the state, which in the case of a potential accident guarantees the reimbursement of damage exceeding a particular limit.

When speaking of the increasing price, we must hereby declare the fundamental argument - the price to a great extent rose also due to a change of technology during the building of Temelin. The originally Soviet-Czech reactor was in the middle of the 1990s supplemented with a control system from the American company Westinghouse, imposing estimated costs of 320 million USD, or approximately 9 billion CZK.

Perhaps the greatest problem of Temelin was, however, that, as time passed, its potential liquidation without completion was became progressively more economically meaningless. In 2000, CEZ's spokesman Ladislav Kriz, for example, estimated that not launching Temelin would cost 84 billion CZK within the arranged investment, and another 1.7 billion for fuel and 10 billion of additional payments arising from closed contracts; all that versus the then value of the company set at approximately 60 billion (see Geussová, 2000c, p. 10).

\section{Power Plant Safety}

It is exactly the power plant's safety that has been and remains the most stimulating and most frequently discussed issue in the public debate.

"We think that the operation of the Temelin nuclear power plant is at the frontier of risk even under normal circumstances. This may be evidenced by constant interruptions of operation, during which the whole primary sector is burdened beyond the bearable, especially the reactor container. The experimental observation of clusters' behaviour during the power plant's full operation is being carried out, as well as the separate monitoring of fuel deformation related to its leakage. A number of smaller and seemingly unrelated technical problems can, however, result in serious malfunctions, which would mean fatal jeopardy of residents' health and lives, not to mention property damage" (see Jihočeské matky, 2007). This is, for example, is the stance of the NGO South Bohemian Mothers, for a long time opposing the power plant, declared in one of the open letters to CEZ.

It is, however, exactly here that the issue of personal perspective on the matter arises most evidently. Safety as such cannot be absolutely ensured in any device, its setting is a techno-political consensus over what safety level implies a minimization of risk proportional to the investment.

In that respect, building basically proceeded in a responsible manner. The originally questioned Soviet technology was enhanced by the systems of Westinghouse. It is true that the power plant (in comparison to, for example, Dukovany nuclear power plant) suffers from a greater number of planned and unplanned interruptions, which are in the majority of cases related to the non-nuclear parts of the facility. From the perspective of EU and Czech standards, the Temelin nuclear power plant is in safety terms, however, unproblematic.

From a decade-long perspective after the power plant was put into operation, the whole construction can be judged from two different points of view. The first emphasizes the importance of a stable, low-emission and predictable power source with unproblematic fuel supplies and with the prospect of decades-long 
functioning. On the other hand, the building process itself does not bring too much optimism. The effort to complete the power plant at any price without considering public opinion, rising cost and financial risk, too frequently appeared as an expression of the personal preferences of the relevant decision-makers rather than as a result of the unbiased assessment of the need for, advantages and costs of this power plant.

\subsection{The Third Phase of Development - EU Membership Through to the Present}

Despite all the problems and delays mentioned, the Czech Republic succeeded in joining the European Union, boasting of a stable energy market with aggressive energy companies, a number of acquisitions abroad and a significant improvement at the level of diversification of energy suppliers. From the beginning of the 1990s, the situation regarding the reduction in the environmentally devastating impact of energy production is incomparable. The significant handicap from the period of the cheap Soviet energy has been improved - low energy efficiency compared to the consumption of primary sources per GDP unit. Despite this, or rather for that reason, it is useful to take a closer look at the current state of the Czech energy sector.

Energy spending of the Czech Republic is slowly rising over the long term in parallel with declining energy demand. After 2000, the economy grew stronger on average by approximately $4.5 \%$ per year, whereas consumption of resources recorded only $2 \%$ of growth per year. Domestic energy demand is still however about a third higher than the EU 27 average (see Zpráva Nezávislé odborné komise). The situation is nonetheless markedly changing as a result of the continuing global economic crisis, which reduces energy demand - well evidenced, for example, by Czech electricity consumption.

Tab. 2.8: Electricity Consmuption 1993-2012

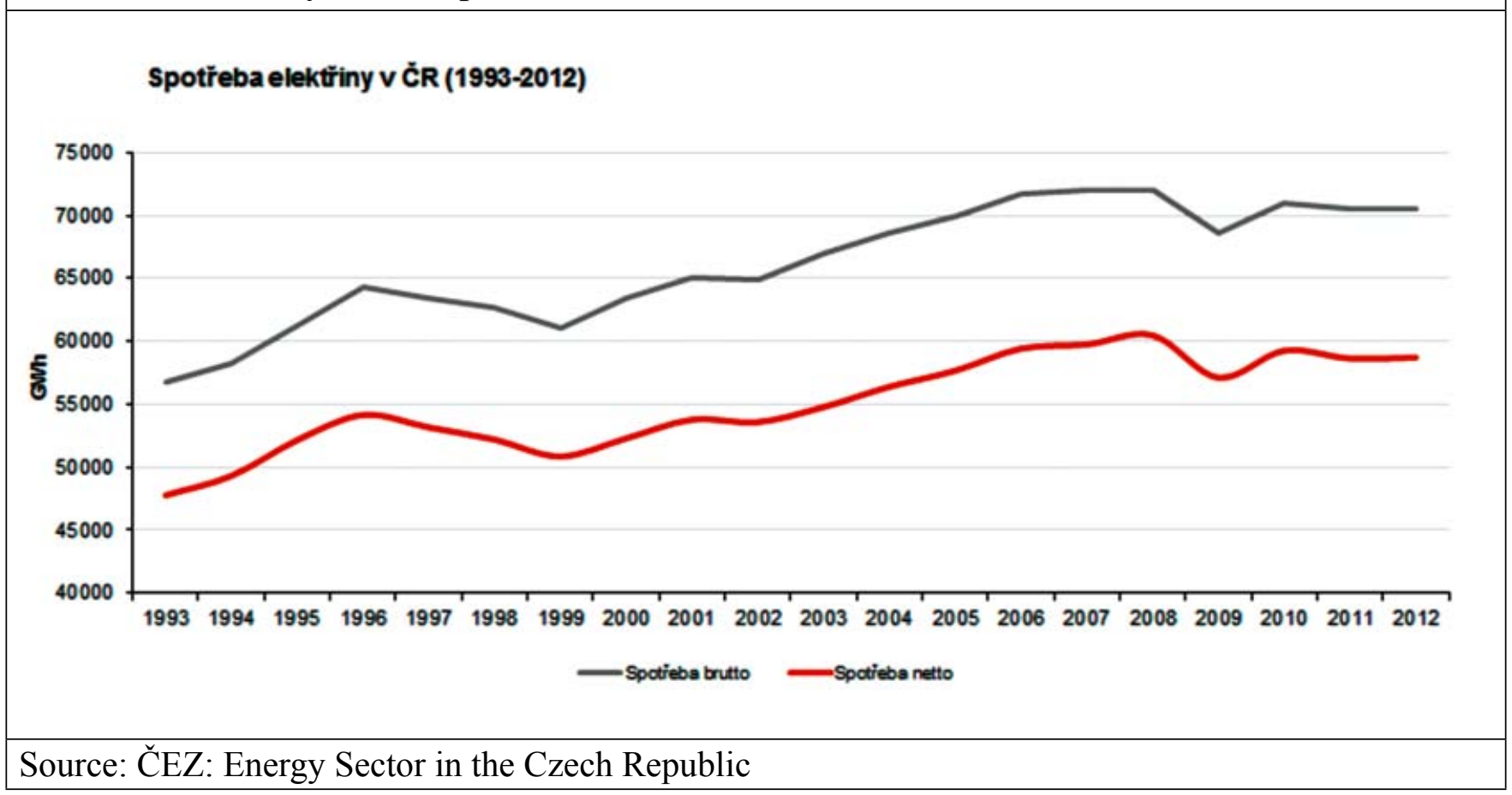


Although it has made a significant shift to natural gas, the Czech Republic is still dependent on two domestic sources, i.e. nuclear fuel and coal. On the other hand, Czech import dependence is for that reason below the EU average, today a little above 40 \% (see Zpráva Nezávislé odborné komise).

As far as the electricity market is concerned, the latter has been completely open since January 1 , 2006, and all customers, including households, can choose their own provider. Since the start of the whole process in 2002, 80,000 customers have made use of this opportunity (Ibid., p. 26). Since March 2007, the electricity exchange market has been the most active platform at the local level (Power Exchange Central Europe, previously the Prague Energy Exchange), active also in Slovakia and Hungary. It has in that manner quite significantly contributed to the transparency of prices and trading with electricity, while a notable volume of this commodity, however, has remained traded on the basis of bilateral contracts. The price of electricity predominantly depends on the prices of input fuels, their total increasing consumption in the EU as well as expenses related to emission allowances. Prices are of course not centrally decided, but aside from the price of power itself, the price of the final product is in all its further charges (for example, transport) subjected to the regulation of the Energy Regulatory Office.

The gas market has been also open since 2007. The fact that it is a set of eight rather independent supply zones is, however, not particularly advantageous for competition, which is why competition happens primarily when looking for large lucrative customers.

The domestic energy situation is, therefore, stabilized, whether in terms of the facts on the ground, its legislative and institutional modifications or in relation to other policies. On the other hand, some new problems are naturally coming to the fore which we must take account of and address in the immediate future.

The first is the issue of the Czech Republic as an important exporter of electric power. Domestic electricity production was already during the Soviet period significantly oversized, due to the country's previous orientation to the metallurgical industry with its high energy consumption. Because the production capacity was, after a reduction in industry demand in recent years, enhanced by the completed Temelin nuclear power plant, we can from 2000 to 2012 observe a continuous growth in electricity exports (the balance of exports in that period increased from $10 \mathrm{GWh}$ to $17.4 \mathrm{GWh}$ ) (see Zpráva Nezávislé odborné komise, p. 14 and Česko loni vyvezlo rekordní množství elektřiny). The Czech Republic is for that reason the second largest net exporter of electricity in the EU after France.

This production, on the other hand, makes great demands for the consumption of domestic energy sources, i.e. coal. It is not moreover clear how long this trend will be sustainable. Even though consumption is increasing only very moderately, trouble may arise on the production side, mainly in relation to the obsolescence of production capacity (power plants). The great majority of them date back before 1989 and they are slowly reaching the end of their lifespan. This is however only a Czech phenomenon, as $50 \%$ of nuclear and $70 \%$ of the coal facilities in the EU are older than 20 years (Ibid., p. 13). It is exactly in this where future problems of the European electricity trade may arise, as the space for export of individual countries will markedly derogate.

The situation is, of course, not critical, as the appropriate combination of savings ${ }^{41}$, restoration of old and perhaps construction of new sources as well as stress on further increases in energy efficiency can solve the problem. It, nonetheless, requires long-term planning and various steps taken sufficiently ahead

41 Iwwn this context, we can compare two perspectives which currently have a significant impact on the debate about the future of the EU and the Czech Republic. According to one, the increase in consumption and obsolescence of sources is a clear indicator of a coming shortage of electricity, which can be solved only by building new power plants, to a certain extent initiated by the state. The opposing perspective claims that high consumption depends on currently rather cheap electricity, which does not force the introduction of the saving measures. Future increasing prices due to electricity shortages will, therefore, lead to higher prices, greater savings and the construction of new sources sponsored by private entities. 
of time. ${ }^{42}$ And this is exactly the argument of those interested parties ${ }^{43}$ asking for the removal of mining limits $^{44}$ mainly in Northern Bohemia. Specifically, it is the CSA and Bilina Quarries, whose production is aimed mainly for large heating plants such as Opatovice or Pribram.

The core of the problem lies in the fact that brown coal in the Czech Republic is a source covering approximately one third of total thermal energy supplies and more than a half of the central heating supply system. Given the limits and gradual lessening of exploitable reserves, the termination of local mining threatens to take place before 2060, with intermittent declines already in 2010-2015, before 2025 and before 2040. Moving the limits, which would inevitably lead to notable landscape devastation and disruption of the functioning of the entire area, would prolong these deadlines for as much as 50 years (see Zpráva Nezávislé odborné komise, p. 16).

If we disregard the commercial interests of the companies running the mines, it is basically again a dispute over the concept and understanding of the energy industry as such. On one side, we see stress placed on maximum energy self-sufficiency secured by production; on the other side, social and environmental aspects are highlighted as well as the general interest to produce energy from other (mainly renewable) sources, and potentially to lower consumption.

Whatever the case, both the above-mentioned problems indicate that a significant part of the future debate over the Czech energy sector will be about the environmental issue, at least in the background. The energy sector is one of the worst polluters of the environment, which is why it is exposed to progressively more intensive criticism at the level of the state, the EU and worldwide. The influence which these discussions might have on Czech energy policy can be illustrated by the issue of emissions allowances.

The latter are the tool which EU member states decided to employ in an effort to reduce $\mathrm{CO}_{2}$ emissions. Basically it is refers to the situation where each crucial producer of these emissions in the EU industry and energy sectors must limit this production by reducing it to the level determined by emissions allowances. They are allocated to single states after they submit a calculation of how much of these allowances they need. The European Commission requested amount revises these (usually downwards). The amount of granted allowances is dropping over time, and companies which lack these allowances must make financial compensation for surplus $\mathrm{CO}_{2}$ production or buy allowances from their competitors.

42 Construction of a nuclear power plant, including obtaining all necessary materials arising from legislation, takes approximately fifteen years, while coal power plants require only half the time.

43 The major proponents of removal or movement of limits are understandably the representatives of energy companies, headed by Mostecka uhelna and Severocesky doly, a. s. (owned by CEZ). This is also the stance shared by CSSD and KSCM. Permanent opposition comes from the Green Party, which thanks to its participation in Topolanek's government possessed the means of preventing mining. The importance of the issue of coal mining beyond the limits is best evidenced by the statement of Prime Minister Mirek Topolanek, who, after a vote of no-confidence had been passed on his government, noted at a press conference: "If you are interested in why our government collapsed, look at Mostecka uhelna, it is a nice package of money" (see Spurný, 2009). The mentioned connection was, however, never proven and neither was the Prime Minister himself willing to further elaborate on this very serious claim.

44 That is certain limitations of bordering areas, separating where the mining is and is no longer allowed. In 1991 the limits were enforced by Minister of the Environment Ivan Dejmal, through Government Decree No. 444. 
Unlike the concept, which seemed efficient, the realization of the whole plan did not have much success. In both rounds of allowance distribution in the Czech Republic (2005-2007 and 2008-2012), the state yielded under the pressure of companies ${ }^{45}$, and submitted to the European Commission an application for a volume far exceeding their needs. After the Commission reduced this amount, approximately $10 \%$ more allowances were allocated than the companies could even use. This essentially Europe-wide approach, reaching its peak with plunging prices of allowances, naturally did not lead to a reduction in emissions, but at least at the beginning did it affect electricity prices, when producers and traders strove to have them include the expected increase in costs (see Zpráva Nezávislé odborné komise, p. 21-23).

EU member states for that reason recently decided to proceed differently and the allowances from 2013 are not allocated as so far for free but are auctioned. They encompass a larger volume of greenhouse gases but address only limited categories of great polluters. In line with the original idea, the number of allowances is from recently also progressively limited in order to reduce emissions by $21 \%$ in comparison to 2005 rates by 2020 .

The system has the potential to notably influence the new EU members with their more outdated industry, producing a greater volume of emissions and getting electricity primarily from coal. An exception was for that reason made, according to which the states can in case of need and under particular delineated provisions allocate a part of the allowances to its producers for free, with the gradual phasing in of payments by $2020{ }^{46}$

The Czech Republic has also used this opportunity, nonetheless in a strongly criticized manner, which did not help to remove the label from the Czech energy sector as being extraordinarily linked to politics. The norm excusing the companies to pay the fees in exchange for investment into more environmental and modern operation was, therefore, enforced in the form of a rider to the amended act on excise duties, moreover, by a temporary "bureaucratic" government lacking an electoral mandate. The arguments favouring the need for this act can be also challenged, as it was quite openly declared as aid to CEZ in the estimated amount of less than 70 billion CZK (see Emisní povolenky pro ČEZ zdarma?). The prohibition of increasing electricity prices was not too relevant with respect to its trading at the exchange, which would anyway be influenced by the allowances thanks to the more expensive electricity from abroad. ${ }^{47}$

The last of the constantly arising problems has a geopolitical and security character. It is a continually more self-confident Russian energy policy and its open economic-political context. Moscow thus not only sees its rich natural reserves as a source of economic prosperity, but also as an instrument of its foreign policy. In this light we should observe for example the New Year's Eve quarrels between Ukraine and Russia over the prices and gas volumes, which escalated in 2006/2007 and 2008/2009. ${ }^{48}$ In the second case the disagreement escalated to the extent that the flow of natural gas through Ukraine to Europe was interrupted, causing ten states receiving supplies through this route to experience a serious shortage of gas.

45 Today there are 400 facilities involved in the allowance trading system, starting with power plants and heating plants, then glass and metallurgical companies, through to coking plants and refineries. The system in that manner covers about $65-70 \%$ of all Czech $\mathrm{CO}_{2}$ emissions.

46 For more detail, see for example the EU ETS.

47 Neither did the soon emerging affair contribute to this unclear situation. Only several weeks after passing the legal rider, photographs were released showing Prime Minister Topolanek, CSSD Deputy Milan Urban (one of the rider's proposers), CEZ lobbyist Vladimir Johanes and others on a joint holiday in Tuscany. Such holidays are not illegal, but it remains questionable how ethical they are.

48 This text does not aim to analyse the cause of this crisis nor does it look for whom to blame. What is, however, substantial for the Czech Republic is that Russian gas exports, making up approximately two thirds of the Czech consumption, pass through Ukraine. Interruption of supplies for whatever reason has a serious impact on domestic energy security. 
By increasing its imports through Germany, the Czech Republic was not significantly affected and was therefore in a position to offer help to critically threatened Slovakia, while this problem however remains a serious challenge to the future planning of energy policy. Excessive energy dependence on a single supplier can have a significantly negative impact on any country's freedom to manage its foreign policy, including the Czech Republic. The fact that Russia is the fundamental and practically irreplaceable supplier of both oil and natural gas cannot be ignored either, as, under the current circumstances neither the EU nor the Czech Republic have a replacement. Solving this problem will probably rely both on persistent efforts to obtain other than Russian sources as well as on considered and consistent diplomacy directed at Moscow. 


\section{Chapter 3: The Coal Sector}

Tomáš Vlček

\subsection{Introduction to the Coal Industry}

Thermal power plants (powered by brown coal, bituminous coal, biomass and light fuel oil) in the Czech Republic provide 10,644 MW of installed capacity, which makes up 51.9\% of the power-energy mix. ${ }^{49}$ The largest heating plants in the Czech Republic are Prunerov II (1,050 MW), Pocerady $(1,000$ MW), Detmarovice, Chvaletice and Tusimice II (up to $800 \mathrm{MW}$ ). All these power plants are in the ownership of CEZ, a. s. (see Energetický regulační úřad [ERÚ], 2011a). The largest power plants which conduct biomass combustion are Tisova I (1 block of $57 \mathrm{MW})$, Porici (1 block of $55 \mathrm{MW})$, Hodonin (1 block of $55 \mathrm{MW}$ ) and the Dvur Kralove heating plant (1 block of $6.3 \mathrm{MW}$ ), also owned by CEZ (see ERÚ, 2010b, p. 88). CEZ at this point is also building an entirely new coal block with $660 \mathrm{MW}$ of capacity in the Ledvice power plant and is modernizing the Prunerov power plant.

All the coal-fired power plants in the Czech Republic are equipped with subcritical or critical boilers, the efficiency of which ranges around 30-38\%. The first supercritical block in the Czech Republic, which implements a greater efficiency (up to $47 \%$ ) ${ }^{50}$ of coal combustion with a reduced amount of pollution emissions, is the block of the Ledvice power plant with a capacity of $660 \mathrm{MWe}$, completion of which is expected by 2014. In terms of the environmental impact and economy of operational process, subcritical blocks are completely comparable to stream power plants powered by natural gas.

Thermal power plants can be divided into two categories, namely condensing power plants and heating plants. Condensing power plants serve for power production, which means that, following the execution process, all the steam sent to the turbine condenses into water inside a condenser. Unlike condensing power plants, heating plants, in addition to power, also supply thermal energy (in the form of steam for heating of water) for heating systems and similar purposes.

49 See the chapter about the electric power industry.

50 Terminology from Kolat, Roubíček, \& Kozaczka, 2008, p. 20. 


\begin{tabular}{|c|c|c|c|c|}
\hline Power Plant & Owner & Installed Capacity & $\begin{array}{l}\text { Connected to the } \\
\text { Network }\end{array}$ & Fired on \\
\hline Detmarovice & CEZ, a. s. & 800 MWe $(4$ x 200) & $1975-1976$ & Bituminous coal \\
\hline Chvaletice & CEZ, a. s. & 800 MWe $(4$ x 200) & $1977-1978$ & Brown coal \\
\hline Kladno & Alpiq Generation (CZ), s. r. o. & $\begin{array}{l}305.966 \mathrm{MWe}(1 \times 28 \\
2 \times 135.533,1 \times 6.9)\end{array}$ & 1976, 1999 & $\begin{array}{l}\text { Bituminous coal, } \\
\text { brown coal }\end{array}$ \\
\hline Komorany & $\begin{array}{l}\text { United Energy pravni nastupce, } \\
\text { a. s. }\end{array}$ & $\begin{array}{l}239 \text { MWe }(4 \times 32,1 \times 20 \\
1 \times 22,1 \times 34,1 \times 35)\end{array}$ & $\begin{array}{l}1959,1978,1986 \\
1994,1997,1998\end{array}$ & Brown coal* \\
\hline Ledvice & CEZ, a. s. & 330 MWe $(3 \times 110)$ & 1967 & Brown coal \\
\hline Melnik (II, III) & CEZ, a. s. & 720 MWe $(2 \times 110,1 \times 500)$ & 1971,1981 & Brown coal \\
\hline Melnik (I) & ENERGOTRANS, a. s. & 352 MWe $(4 \times 60,2$ x 56) & 1961, 1994-1995 & Brown coal \\
\hline Opatovice & Elektrarny Opatovice, a. s. & 363 MWe $(5 \times 60,1$ x 63$)$ & $1979,1987,1995-1997$ & Brown coal \\
\hline Pocerady & CEZ, a. s. & 1,000 MWe $(5$ x 200$)$ & 1970-1977 & Brown coal \\
\hline Porici & CEZ, a. s. & 165 MWe $(3 \times 55)$ & 1957 & $\begin{array}{l}\text { Brown coal, bitu- } \\
\text { minous coal* }\end{array}$ \\
\hline Prunerov & CEZ, a. s. & $1,490 \mathrm{MWe}(4 \times 110,5$ x 210$)$ & 1967-1968, 1981-1982 & Brown coal \\
\hline Tisova & CEZ, a. s. & $\begin{array}{l}295.8 \text { MWe }(3 \times 57,1 \times 12.8 \text {, } \\
1 \times 112)\end{array}$ & $1959-1961$ & Brown coal* \\
\hline Trebovice & Dalkia Ceska Republika, a. s. & 174 MWe $(2$ x 72,1 x 30$)$ & 1961,1998 & $\begin{array}{l}\text { Bituminous coal, } \\
\text { light fuel oil }\end{array}$ \\
\hline Tusimice & CEZ, a. s. & 800 MWe $(4$ x 200) & 1974-1975 & Brown coal \\
\hline \multicolumn{5}{|c|}{$\begin{array}{l}\text { * The Komorany power plant is also partially fired by natural gas. One } 55 \mathrm{MW} \text { block of the Porici power plant and one } 57 \mathrm{MV} \\
\text { block of the Tisova power plant employ biomass combustion. } \\
\text { Source: Energetický regulační úrad, } 2010 \mathrm{~b}, \text { p. } 88,92 \text {. }\end{array}$} \\
\hline
\end{tabular}

\subsection{Deposits, Mine Production, Companies and Traders}

\subsubsection{Lignite}

Lignite is one of the youngest caustobioliths ${ }^{51}$ from the series of humoliths. Peat is an even younger caustobiolith, which was mined on Czech soil in the 1960s in the peat bog in Vracov in Southern Moravia, an area now only covered by a natural lake. Compared to brown coal, lignite has a higher content of water and a lower content of carbon, which naturally means that it possesses a lower calorific value.

The extraction of lignite has a rich history tied to the region of South Moravia. If we exclude smaller deposits and a minor scale of extraction which took place in Ceske Budejovice and the Zitavska Basins, by far the largest deposits are to be found in the Viennese Basin. The underground extraction of lignite started in the banks of Kyjov and Dubnan in the South Moravian Lignite Basin already in 1824 and terminated in 2009 with the closing of the last mine (Mir v Mikulcicich). Between 1825 and 1994, 93,180,200 tonnes of lignite was mined (see UVR Mníšek pod Brdy, a. s.).

51 Combustible fossil, the term means a fossil fuel. 
The mining was done by Lignit Hodonin, s. r. o., with its headquarters in Mikulcice, owning the Mir Mine. The only customer was the Hodonin power plant built in 1951-1957. In order to justify its existence, the obsolete power plant in Hodonin with a capacity of $105 \mathrm{MWe}$ (one $55 \mathrm{MWe}$ block and one $50 \mathrm{MWe}$ block) has in recent years started to specialize in biomass combustion. One of the reasons for this shift can be seen in the continuously increasing price of lignite. The owner of the power plant, CEZ, was frequently turning it off and restricting its operations in order reduce emissions. The result was that the only supplier of lignite, Lignit Hodonin, s. r. o., which for a long time had struggled with economic problems, was not able to cope with the loss of its exclusive customer, which is why in September 2009 it declared itself insolvent. Management was temporarily taken over by s. p. DIAMO, so that extraction in the Mir Mine actually ended on December 23, 2009. On August 31, 2010, as part of the tendering process, the company was, together with its 60 employees, purchased by UVR Mnisek pod Brdy, a.s., which does not plan any resumption of mining. The company's plans for the future include the development of the facility for processing all kinds of waste (for example, separation and grinding with subsequent biological and energy employment), processing of liquid and hazardous waste, setting up a repair service for cargo vehicles and the construction of a solar power plant (see UVR Mníšek pod Brdy, a. s.). A reduction regime is to be established in the mine, while the extraction of lignite will not be re-launched for the time being.

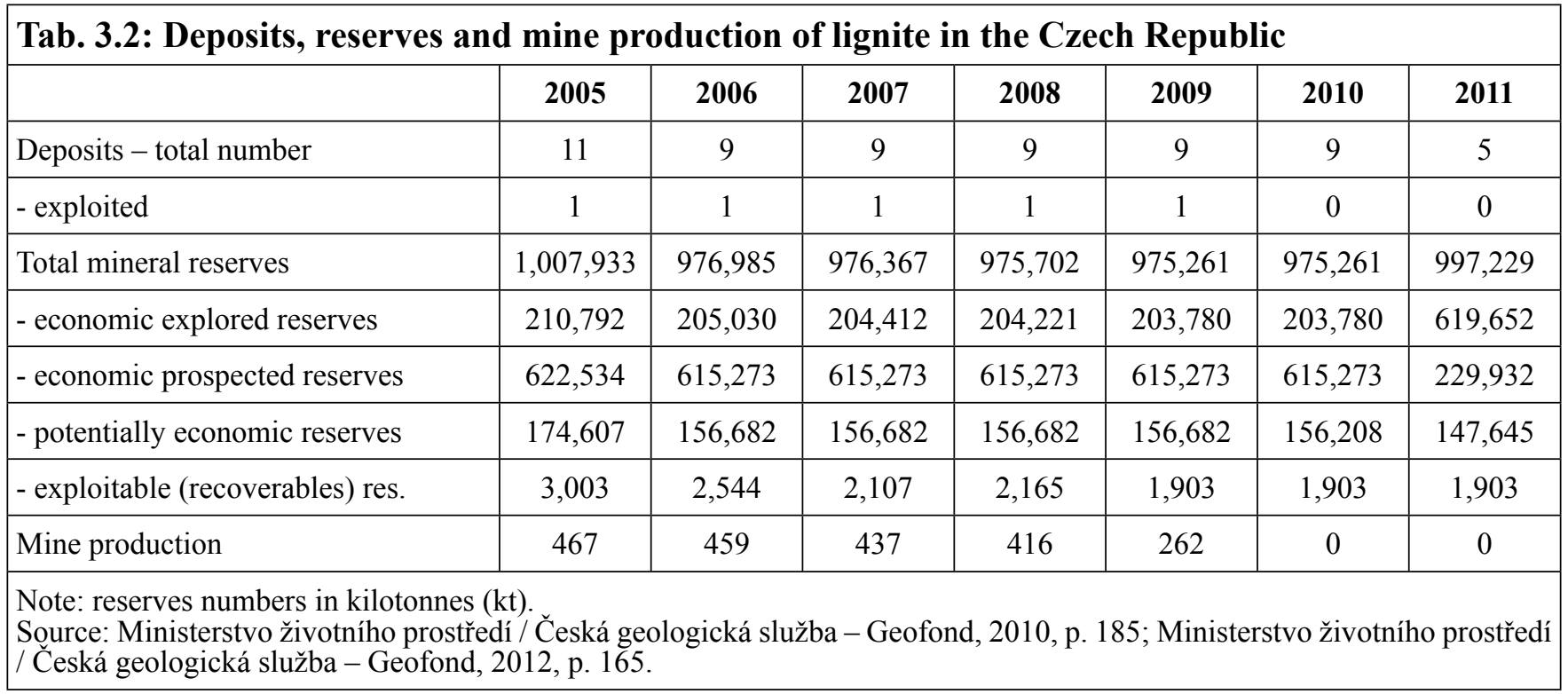

\subsubsection{Brown Coal}

Brown coal is a humolith with $65-69 \%$ carbon and $17-24 \mathrm{MJ} / \mathrm{kg}$ of calorific value. Brown coal is the main source of energy in the Czech Republic, and domestic extraction for now fully covers the domestic consumption. Brown coal is not imported, and only insignificant amounts are exported (around 1-2 million tonnes per year, mainly to Slovakia). The greatest deposits are located in the Mostecka (former North Bohemian Basin), Sokolovska, Chebska and the Zitavska basins, while only the first two are being exploited. 


\begin{tabular}{|c|c|c|c|c|c|c|c|}
\hline & 2005 & 2006 & 2007 & 2008 & 2009 & 2010 & 2011 \\
\hline Deposits - total number & 55 & 54 & 54 & 54 & 54 & 54 & 53 \\
\hline - exploited & 9 & 9 & 9 & 9 & 10 & 10 & 10 \\
\hline Total mineral reserves & $9,423,625$ & $9,192,305$ & $9,140,769$ & $9,090,892$ & $9,055,290$ & $8,998,999$ & $8,948,767$ \\
\hline $\begin{array}{l}\text { - economic explored } \\
\text { reserves }\end{array}$ & $2,616,759$ & $2,562,306$ & $2,516,982$ & $2,608,212$ & $2,789,379$ & $2,405,345$ & $2,361,825$ \\
\hline $\begin{array}{l}\text { - economic prospected } \\
\text { reserves }\end{array}$ & $2,305,437$ & $2,305,437$ & $2,305,437$ & $2,168,466$ & $2,168,466$ & $2,063,444$ & $2,063,444$ \\
\hline $\begin{array}{l}\text { - potentially economic } \\
\text { reserves }\end{array}$ & $4,501,429$ & $4,324,562$ & $4,318,350$ & $4,314,214$ & $4,097,445$ & $4,530,210$ & $4,523,498$ \\
\hline \begin{tabular}{|l} 
- exploitable \\
(recoverables) res.
\end{tabular} & $1,045,968$ & 978,839 & 931,488 & 886,223 & 862,633 & 915,100 & 871,142 \\
\hline Mine production & 48,658 & 48,915 & 49,134 & 47,456 & 45,354 & 43,931 & 46,848 \\
\hline
\end{tabular}

There are three companies active in the extraction of brown coal in the Czech Republic: Severoceske doly, a. s., Skupina Czech Coal, a. s., and Sokolovska uhelna, pravni nastupce, a.s. ${ }^{52}$

Severoceske doly, a. s. is located in Chomutov. The hundred per cent owner of the company is CEZ. In 2009, it achieved a $48.61 \%$ share at the brown coal market in the Czech Republic, which makes it the largest brown coal company in the Republic. The extraction takes place in Nastup Tusmice and Bilina Mines (see Severočeské doly, a. s., 2010).

Skupina Czech Coal, a. s. is located in Most and it is in the full ownership of the companies Indoverse Czech Coal Investments Ltd. (50\%) and Czech Coal N.V. (50\%), from behind the scenes supported by the financiers Pavel Tykac and Jan Dienstl. The group gathers together Vrsanska uhelna, a.s., Most; Litvinovska uhelna, a.s., Most; Czech Coal, a. s.; Dul Kohinoor, a. s., Dolni Jiretin; Czech Coal Services, a. s. and approximately 30 other smaller companies engaged in power and heat production and services. In 2009, it had a $31.87 \%$ share of the brown coal market in the Czech Republic, which makes it, therefore, the second largest brown coal mining company in the country. The extraction takes place in the CSA Mine (Litvinovska uhelna, a. s.) and Vrsany (Vrsanska uhelna, a. s.) (see Skupina Czech Coal, 2010). One of the Group's daughter companies, Dul Kohinoor, a. s., also operates the last working underground mine in the Czech Republic, Dul Centrum.

The last company ${ }^{53}$, Sokolovska uhelna, pravni nastupce, a. s., located in Sokolov, is owned by Frantisek Stepanek (40 \%), Jaroslav Rokos and Jan Krouzecky (each $30 \%$ ), who accordingly occupy the top positions within the company. In 2009, it had an $18.94 \%$ share at the brown coal market in the Czech Republic. Extraction proceeds in the mines Jiri and Druzhba (see Sokolovská uhelná, právní nástupce, a. s., 2010).

52 The Czech Coal Group joins together the three companies really active in the field of coal mining, namely Vrsanska uhelna, a. s., Litvinovska uhelna, a. s. and Dul Kohinoor, a. s. Coupled with Severoceske doly, a. s. and Sokolovska uhelna, pravni nastupce, a. s. there are, therefore, five coal mining subjects in the Czech Republic.

53 In 2009, Lignit Hodonin, s. r. o. also had a $0.58 \%$ share (262,000 tonnes) of the brown coal market. 
It is particularly brown coal that should be observed with reference to territorial environmental limits on mining (see below). According to the Czech Geological Survey, exploitable reserves of brown coal as of December 12, 2011, were approximately 870 million tonnes, while the Institute for Energy information estimates it was approximately 912 million tonnes. The extraction of approximately 45 million tonnes, therefore, ensures reserves for roughly 19 to 20 years, should the present pace of extraction be maintained. Beyond these capacities of brown coal, there are another approximately 900 million tonnes of coal located in the CSA, Bilina and Vrsany open cast mines, which would prolong the lifespan of reserves for another 20 years, should the present pace of extraction be maintained. ${ }^{54}$

\section{Tab. 3.4: Exploitable Reserves of Brown Coal and Their Limits}

\begin{tabular}{|c|c|c|c|c|c|c|}
\hline \multirow{2}{*}{ Basin } & \multirow{2}{*}{ Company } & \multirow{2}{*}{$\begin{array}{l}\text { Open Cast } \\
\text { Mine }\end{array}$} & \multicolumn{4}{|c|}{ Exploitable Reserves } \\
\hline & & & As of 1/1/ 1999 & As of 1/1/ 2007 & As of $1 / 1 / 2008$ & As of 31/12/ 2009 \\
\hline \multirow{7}{*}{$\begin{array}{l}\text { North } \\
\text { Bohemian } \\
\text { Basin }\end{array}$} & \multirow{4}{*}{ Czech Coal Group } & CSA & 92,000 & 49,900 & 45,000 & 37,300 \\
\hline & & Vrsany & 316,000 & 220,900 & 210,300 & $305,000^{*}$ \\
\hline & & Centrum & - & 400 & 200 & 0 \\
\hline & & In total & 408,000 & 271,200 & 255,500 & 342,300 \\
\hline & \multirow{3}{*}{ Severoceskedoly, a. s. } & $\begin{array}{l}\text { Nastup - Tus- } \\
\text { mice }\end{array}$ & 412,000 & 297,800 & 285,500 & 247,000 \\
\hline & & Bilina & 232,000 & 211,400 & 202,200 & 196,000 \\
\hline & & In total & 644,000 & 509,200 & 488,000 & 443,000 \\
\hline \multirow{3}{*}{ Sokolovska } & \multirow{3}{*}{$\begin{array}{l}\text { Sokolovska uhelna, } \\
\text { pravni nastupce, a. s. }\end{array}$} & Jiri & 189,000 & 125,500 & 117,700 & \multirow{2}{*}{127,000} \\
\hline & & Druzhba** & 82,000 & 72,900 & 69,600 & \\
\hline & & In total & 271,000 & 198,400 & 187,300 & 127,000 \\
\hline \multicolumn{3}{|c|}{ The Czech Republic in total } & $1,323,000$ & 981,300 & 932,900 & 912,300 \\
\hline \multicolumn{7}{|c|}{$\begin{array}{l}\text { Note: figures indicated in thousands of tonnes. Forecast for } 2013 \text { according to Czech Coal Group and Sokolovske uhelne, a. s. } \\
\text { * Including Sverma Open Cast Mine (with a lifespan of reserves until 2012). } \\
\text { ** Including Marie Mine. For extensive landslide which took place at the end of July 2009, Druzhba Open Cast Mine was in } \\
\text { August } 2011 \text { closed for any further coal mining. } \\
\text { Source: Úřad vlády ČR \& Nezávislá energetická komise, 2008, p. 15; Institut energetických informací, 2011, p. 5.; Valášek, } \\
\text { 2000c, p. 18. Modified and revised by T. Vlček. }\end{array}$} \\
\hline
\end{tabular}

\subsubsection{Bituminous Coal ${ }^{55}$}

Bituminous coal is a humolith with a 69-92\% share of carbon and 24-33 MJ/kg of calorific value. Within Czech territory, there are deposits of both energy and coking bituminous coal (see below), which makes bituminous coal an important element of Czech exports. There are altogether nine bituminous coal basins, however by far the largest as well as the only one mined is the Czech part of the Upper Silesian Coal Basin, respectively the Ostrava-Karvina district.

54 Ladislav Blazek, the former Development Assistant at the Federal Ministry of Fuel and Energy, estimates the amount of brown coal beyond exploitable limits as approximately 1 billion CZK expressed in the present (to 2009 - author's note) price level (see Blažek, 2009, p. 127).

55 Anthracite, the most calorific and best coal, is not produced in the Czech Republic. 


\begin{tabular}{|c|c|c|c|c|c|c|c|}
\hline & 2005 & 2006 & 2007 & 2008 & 2009 & 2010 & 2011 \\
\hline Deposits - total number & 63 & 63 & 63 & 62 & 62 & 62 & 62 \\
\hline - exploited & 11 & 10 & 9 & 8 & 8 & 8 & 8 \\
\hline Total mineral reserves & $16,094,030$ & $16,063,718$ & $16,159,327$ & $16,193,970$ & $16,455,297$ & $16,421,504$ & $16,339,004$ \\
\hline $\begin{array}{l}\text { - economic explored } \\
\text { reserves }\end{array}$ & $1,672,651$ & $1,587,320$ & $1,566,771$ & $1,523,979$ & $1,543,177$ & $1,536,411$ & $1,518,929$ \\
\hline $\begin{array}{l}\text { - economic prospected } \\
\text { reserves }\end{array}$ & $5,880,437$ & $5,869,966$ & $5,876,191$ & $5,928,406$ & $6,011,672$ & $6,009,407$ & $5,998,902$ \\
\hline $\begin{array}{l}\text { - potentially economic } \\
\text { reserves }\end{array}$ & $8,540,942$ & $8,606,432$ & $8,716,365$ & $8,741,585$ & $8,900,448$ & $8,875,686$ & $8,821,173$ \\
\hline $\begin{array}{l}\text { - exploitable (recovera- } \\
\text { bles) res. }\end{array}$ & 269,198 & 134,060 & 182,165 & 192,182 & 205,630 & 168,917 & 180,729 \\
\hline Mine production & 12,778 & 13,017 & 12,462 & 12,197 & 10,621 & 11,193 & 10,967 \\
\hline
\end{tabular}

The only mining organization in the Czech Republic engaged in the production of bituminous coal is namely $O K D$, a. s. (until January 21, 1991, known as Ostravsko-karvinske doly, a. s.). OKD is fully owned by the Dutch company NWR (New World Resources N.V.). It leads the mining works in the Darkov, CSM, Karvina (Karvina-Lazy and Karvina-CSA) and Paskov underground mines. The opening of the Frenstat pod Radhostem mine (in the Beskydy landscape protected area) is at the planning stage. The company also owns two coking plants in Ostrava (see OKD, a. s., 2010)

More than $74 \%$ of OKD production intended for the domestic market goes to the five most significant users: ArcelorMittal Ostrava a. s., Trinecke zelezarny, a. s., Group - Moravia Steel, a. s., OKK Koksovny, a. s., Dalkia Ceska republika, a. s., and CEZ, a. s. The remainder is exported, specifically to Austria, Slovakia, Germany, Poland and Hungary (see $O K D$, a. s.).

OKD plans to continue mining in the Karvina region for another 20 years and it was decided to try to extract coal from the CSM Mine in Stonava underground from the Polish side of the border, where the process would proceed under the river (see Januszek, 2010). The mine in question, Morcinek, is owned by the Polish company Jastrzebska Spolka Weglowa S.A., which was shut down approximately 11 years ago, although it was not mined to its full capacity. In 2010, the mining company New World Resources N.V. unsuccessfully attempted a takeover of the Polish Bogdanka mine. The management of the mine refused to accept the offered price of about 21.3 billion CZK (see Daniel, 2010), which prevented the emergence of potentially one the largest bituminous coal mining companies in Central Europe. In addition to these events, NWR established a daughter company NWR KARBONIA Sp. z o.o. in Poland, through which it is already extracting bituminous coal from the initially closed Debiensko mine. NWR expects that further privatization in Poland will lead to the further company mergers and NWR acquisitions. Debiensko Mine lays $40 \mathrm{~km}$ beyond the border and it had been closed for 10 years. NWR has already obtained a license for coal mining for 50 years, while it, moreover, is attempting to relicense other reserves in the mine to qualify as extractable categories. There are 190 million tonnes of extractable reserves of coking coal. The company plans an investment of up to 800 million euro. 


\subsubsection{Exploitation of Coal and Trading}

The exploitation of coal can be divided into two categories. All kinds of brown coal, lignite and almost one third of domestic extraction of bituminous (so-called energy) coal represent the primary resource for heat and power production resulting from combustion in heating plants, condensing power plans and boiler houses, whereas the heating in most cases comes as a side product of power production. The quality of coal and the modifications made to improve it have a great influence on the combustion process. In order to achieve the best coal combustion and efficient use of its calorific value, fireplaces are being constantly developed. Starting from original grate types, where coal lies on a grate without motion, the technology advanced to the more efficient types of grates with a stationary or circulating fluid surface and powdery fireplace (see Jirásek \& Vavro, 2008).

The second category is the exploitation of coal, namely of particularly black, so-called coking coal, for indirect production of raw iron in the blast furnace. Through the process of regulated warming in the absence of air (carbonization), a metallurgical coke - a hard, steel-grey material with a very high calorific value is extracted from bituminous coal ${ }^{56}$, which simultaneously serves as a fuel and a reducing agent. Next to metallurgical coke (about $75 \%$ ), there are a vast number of side products emerging during the process of carbonization (coking gas, tar, benzene, ammonia, naphthalene, etc.) which can be of good use in the chemical, paper, pharmaceutical, textile and leather manufacturing industries (see Jirásek \& Vavro, 2008). In 2009, 11 million tonnes of bituminous coal was extracted, 5.9 of which was coking and 5.1 energy coal. 2.27 million tonnes of coal was used for the production of coke in the Czech Republic (see Kavina, 2010). The largest (and the only) coking plants in the country are ArcelorMittal Ostrava, a. s.; OKK Koksovny, a. s., the Trinecke zelezarny, a. s. and Group - Moravia Steel, a. s.

In the Czech Republic, only subjects with a permit from the relevant District Mining Authority can proceed with the mining of coal. These subjects are obliged to deliver royalties from the mining site, which is an aspect of extraction approval expressed in money. Only for bituminous and brown coal, from these royalties for remediation, recultivation and mine damages in 2009 the state received more than 1.02 million CZK (see MŽP/ČGS-G, 2010, p. 125-126). All mineral materials within Czech territory are in state ownership to the point of their extraction and the state by means of these fees de facto gives a mining permit to the traders. The coal which is extracted then becomes the property of particular companies.

In the Czech Republic brown coal is traded almost exclusively on a long term contract basis. A user directly contacts the trading department of a particular producer intending to enter into contract with them. Purchase agreements, which are regularly closed for several years (typically 10-15), specify the amounts of material, means of supply, offtake place, transport, calorific value, qualitative parameters of supply (sulphur, water or ash), etc. These long term contracts provide security of supply and operational security for consumers and, on the other hand, security of stable extraction and incomes for suppliers. The Pocerady power plant, for example, burns about 4,000 tonnes of coal per day, the Prunerov I power plant 8,000 tonnes and Prunerov II as much as 20,000 tonnes of coal per day (see "Mrazivé počasí," 2010). The security of stable (and massive) supplies of coal is the highest priority, so that the operating process can proceed without problems.

The trade in bituminous coal, which proceeds either on long-term contract bases as with brown coal or through the commodity stock market HRAPRAKO, is divided into two categories. Bituminous coal of a quality allowing the production of coke for blast furnace production of raw iron, potentially also for

56 In a blast furnace for the production of iron, it is necessary to reach a temperature of 1700 to $1900^{\circ} \mathrm{C}$. The calorific value of coke traded in the Czech Republic ranges between 26 and $29.5 \mathrm{MJ} / \mathrm{kg}$. 
heating purposes, can be found on the market as "coking coal". Other kinds of bituminous coal are marked as "bituminous coal for energy purposes", which mainly serve for the production of electric power (see MŽP/ČGS-G, 2010, p. 162). These categories then make two more or less independent markets.

Brown coal plays almost no part in foreign trade, since following 45.5 million of extracted tonnes in 2009, the balance of foreign trade was 1.2 million tonnes of exports (see MŽP/ČGS-G, 2010, p. 176). The balance of foreign trade in bituminous coal reached a figure of 4.24 million tonnes of exports ${ }^{57}$, while the trade in coke was settled on approximately half a million of tonnes of both exports and imports (see MŽP/ ČGS-G, 2010, p. 166-167). Bituminous coal is one of the most significant items in Czech foreign trade.

\subsection{The Regulatory Framework of the Coal Industry}

Mining in the Czech Republic is legislatively guided by three acts. The key one is, without doubt, Act No. 44/1988 Coll., on the protection and utilization of mineral resources (The Mining Act, see Zákon č. 44/1988 Sb.), followed by Act No. 61/1988 Coll., on mining activities, explosives and the State Mining Administration (see Zákon ČNR č. 61/1988 Sb.) and Act No. 157/2009 Coll., on the disposal of mining waste and amending certain laws (see Zákon č. 157/2009 Sb). The latter came into effect on April 5, 2012.

The Mining Act establishes the principles for the protection and economic exploitation of mineral resources, especially in prospecting and exploration work, opening, preparation and extraction of mineral deposits, processing and refinement of minerals carried out in connection with mining, as well as safety of operations and environmental protection during these processes. According to this Act, mineral deposits within the territory of the Czech Republic are owned by the Czech Republic.

In order to be able to mine coal within our territory, according to The Mining Act, an organization or a company has to obtain the approval of the District Mining Authority, which delimitates a mining area $^{58}$. Prior to submitting a proposal for the delimitation of the mining space, an organization must obtain approval from the Ministry of the Environment issued after consultations with the Ministry of Industry and Trade. The Ministry of Environment may make the issuing of such a prior approval dependent on the fulfilling of conditions related to the creation of a unified raw material policy for the Czech Republic and on the return of means spent from the state budget for search and exploration of reserved deposits.

In Article $\S 32$, the Act also supplies information regarding the fees which the mining organizations are subject to. An organization is obliged to pay to an account of the relevant District Mining Authority an annual fee for the mining claim for each ha or part of the area of the mining claim within its surface boundaries, whereas the Government Order is to set the size of the fee within the range $100 \mathrm{CZK}$ to 1000 CZK graded on the basis of degree of protection of the environment in the affected area, characterization of activities carried out in the mining area and its impact on the environment. The fee amounts to no more than $10 \%$ of the market price of the extracted minerals, whereas the District Mining Authority transfers $25 \%$ of this income to the Czech state budget, from where they would be employed to remedy damage caused to the environment as a result of extraction of reserved and non-reserved deposits, while the remaining $75 \%$ goes to the municipal budget (see Zákon č. 44/1988 Sb.).

57 Imports (mainly from Poland) 1.79 million tonnes, exports (mainly to Austria, Slovakia and Poland) 6.032 million tonnes. (see MŽP/ČGS-G, 2010, p. 166)

58 In terms of hierarchy, the mining area is a set of one or several deposits. 
Act No. 61/1988 Coll., on mining activities, explosives and the State Mining Administration among other things establishes the terms for execution of mining activities and activities executed by mining means, the terms for handling explosives and explosive items and organization and the scope of authority of the State Mining Authority (see Zákon ČNR č. 61/1988 Sb.).

The organs of the State Mining Authority administer mining activity, the observance of working conditions, extraction waste treatment and supervise the observance of Acts Nos. 44/1988 Coll., 61/1988 Coll., 157/2009 Coll. and other regulations (ordinances issued by the Czech Mining Authority, Czech Authority for Safety Work, etc.) (see Státní báňská správa České republiky). The State Mining Authority is the chief supervisor of the mining sector in the Czech Republic. The organs of the State Mining Authority are the Czech Mining Authority (i.e. the Central Mining Authority), located in Prague, and nine District Mining Authorities ${ }^{59}$. The Czech Mining Authority is the central organ of the State Mining Authority of the Czech Republic, whose chairman is appointed and dismissed by the Government. The Czech Mining Authority keeps the overall record of mining areas and of their changes and executes obligations imposed by the European Commission.

Act No. 157/2009 Coll., on the disposal of mining waste and amending certain laws among other points establishes the rules of mining waste treatment and the rules for prevention of environmentally unfriendly influences as a result of mining waste treatment (see Zákon č. 157/2009 Sb.).

Aside from the legislative or regulatory dimension, there is also the Czech Geological Survey (originally the Czech Geological Institute), which is the organ collecting and processing data regarding the geological composition of land and then passing it to administrative organs for political, economic and environmental decision making. The Czech Geological Survey is authorized by the Ministry of the Environment to perform state geological surveys within the territory of the Czech Republic. It is, therefore, the only institution whose mission is coherent exploration of the geological structure over the entire Czech territory (see Česká geologická služba). We should also mention the Brown Coal Research Institute, j. s. c. (VÚHU, a. s.) located in Most, which emerged as part of the transformation of the former state company of the same name. Shareholders of the Institute are Czech Coal, a. s., (44.580\%) and Severoceske doly, a. s., (44.582\%). VÚHU, a. s., conducts exploratory, consulting, commissioning and servicing activities, primarily directed at mining-related issues (see Výzkumný ústav pro hnědé uhlí, a. s.).

In terms of the supranational legislative framework, there are a few directives of the Council of the European Union and of the European Commission regarding explosives for civil use (for example 93/15/ EEC or 2004/57/EC). The European Association for Coal and Lignite (EURACOAL), functioning outside the regulatory framework, emerged in 2002 as a result of the transformation of the European Committee on Solid Fuels (CECSO), covering the field of the European coal industry. EURACOAL is a lobbying organization which gathers 33 producing and importing companies and research institutes in Europe. The goal of the organization located in Brussels is to warn about the importance of coal in terms of security, competitiveness and sustainability of energy supplies in Europe and to contribute to the establishment of a satisfactory European regulatory framework (see European Association for Coal and Lignite). EURACOAL is in no manner connected to the EU institutions, while during its work it does cooperate with the European Commission and European Parliament. The member of EURACOAL in for the Czech Republic is the Employers' Association of Mining and Oil Industries of the Czech Republic, which is an independent and voluntary organization whose chief mission is to protect the interests of its members and formulate and pursue their objectives during negotiations with state administrative organs, unions and other institutions. It consists of 22 companies, organizations and institutes which together de facto represent the entire coal sector of the Czech Republic. 
Keeping strategic reserves of coal is not legally required in the Czech Republic; in reality, however, each coal power plant does have certain "strategic" loads of coal, but with regard to the enormous volume of coal which is burned every day, it is barely sufficient for a couple of days of operation. If coal freezes during the winter, the situation is resolved by rotting the upper layer and subsequent collection or extraction underneath, where the coal is powdery, respectively in its normal state.

\subsection{Demand Forecast}

One of the basic priorities declared in the 2004 State Energy Concept is maximum independence from foreign energy sources, energy sources from risky regions and reliability of supplies from foreign sources (see "SEK", 2004, p. 3). One of the easiest ways to achieve these goals is to exploit domestic sources of energy, particularly coal, which is a component of all the Policy's revisions. The role of coal will inevitably decline, particularly in the electric power and heating industries where it will be replaced by renewables, nuclear energy, biomass and decentralized smaller cogenerating units of local heating systems.

\begin{tabular}{|c|c|c|c|c|c|c|c|c|}
\hline \multicolumn{9}{|c|}{$\begin{array}{l}\text { Tab. 3.6: The Shares of Solid, Liquid and Gas Fuels in Energy Resource Consumption According to } \\
\text { the State Energy Policy of the Czech Republic from } 2004 \text { and Its Updates from February } \\
2010 \text { and August } 2012 \text { (in \%) }\end{array}$} \\
\hline \begin{tabular}{|l|} 
Type of Fuel \\
\end{tabular} & \begin{tabular}{|c|} 
Level in \\
2000
\end{tabular} & \begin{tabular}{|c|} 
Level in \\
2005
\end{tabular} & \begin{tabular}{|c|} 
Level in \\
2008
\end{tabular} & $\begin{array}{l}\text { Long-Term } \\
\text { Goal (SEP } \\
\text { 2004) by } \\
2030\end{array}$ & $\begin{array}{l}\text { "Green" } \\
\text { Scenario } \\
\text { (SEP 2004) } \\
\text { year 2030 }\end{array}$ & $\begin{array}{l}\text { Revised SEP } \\
(2 / 2010) \\
\text { Scenario by } \\
2030\end{array}$ & $\begin{array}{l}\text { Revised SEP } \\
\text { Scenario } \\
(2 / 2010) \text { by } \\
\quad 2050\end{array}$ & $\begin{array}{l}\text { Revised SEP } \\
\quad(8 / 2012) \\
\text { Target Values } \\
\quad \text { by } 2040\end{array}$ \\
\hline Solid & 52.4 & 42.5 & 45.3 & $30-32$ & 30.5 & 24 & 20 & $12-17$ \\
\hline Gas & 18.9 & 21.6 & 15.7 & $20-22$ & 20.6 & 20 & 21 & $20-25$ \\
\hline Liquid & 18.6 & 15.7 & 20.9 & $11-12$ & 11.9 & 20 & 19 & $14-17$ \\
\hline Nuclear & 8.9 & 16.5 & 15.3 & $20-22$ & 20.9 & 25 & 25 & $30-35$ \\
\hline Renewables & 2.6 & 5.4 & 2.9 & $15-16$ & 15.7 & 11 & 15 & $17-22$ \\
\hline
\end{tabular}

While solid fuels currently have a 45 to $50 \%$ share in total consumption of primary energy sources in the Czech Republic, this share should, according to the long term goal declared in the 2004 State Energy Concept, decrease to a level of approximately $30 \%$. The Revision of the State Energy Concept from February 2010 presumes the use of solid fuels will be down to $24 \%$ by 2030 and $20 \%$ by 2050 , while the Revision from August 2012 is even more pessimistic, predicting a decline of solid fuel use to a level of $12-17 \%$ by 2040.

The coal industry at the moment truly stands at the threshold of a major change. A century of steam had ended long ago and energy can be nowadays produced in many different ways with a notably friendlier approach to the environment. In the competition between natural gas, renewables and biomass on one side and coal on the other, coal is for now still the ultimate winner, mainly thanks to its substantially lower price. Emission allowances, the massive interest of the European Union in renewables and the increasing price of domestic coal as a result of the initial phase of a shortage, however, is gradually removing the competitive advantage of coal, which will with great likelihood cease being the cheapest fuel in the next couple to tens of years. 
On the other hand, all system power plants in the Czech Republic depend on coal. Even though these power plants will gradually terminate with their activities in the next two decades, this does not at all mean that the exploitation of coal in the Czech Republic will end sharply sometime in the next twenty years ${ }^{60}$. A timely decision regarding the future and further direction of the Czech energy sectors is of key importance (approval of the Revision of the State Energy Concept), an issue which lies on the shoulders of the state. A massive departure from coal energy is not to be expected, but rather its rationalisation. Coal energy is expected to experience a qualitative change toward clean technologies, greater efficiency and savings. Modern technologies which are expected to have a significant role in the future power industry are cogeneration with fuel segments and combusting gas obtained by gasification of coal (Hermann, Noskievič, \& Kolat, 1998, p. 306). Moreover, on the basis of coal production, the Czech Republic takes the third place in the European Union (22,785 tonnes of all sorts of extracted coal in 2008), behind Poland (60,536 tonnes) and Germany (50,040 tonnes) ${ }^{61}$ (see Český statistický úřad, 2011).

If the state wishes to find a substitute for coal for electricity purposes, a truly massive nuclear route is required (see Kavina, 2009, p. 320). To maintain the role of coal without simultaneously breaching the limits, it would be necessary to import coal from abroad. Each additional kilometre of road has, however, a significant impact on the price of power production from coal, and the transport also represents an additional burden on the environment. The nuclear route of substitution of coal is, in addition, technically and technologically infeasible. The Paces Commission pointed out that "... should the suspension of extraction works in Bilina and CSA quarries occur, it would affect the change of fuel bases and technologies primarily in the large heating plants, the necessity to import fuels (bituminous coal, natural gas), potentially to shift to renewables. It would both cause increasing import dependence of the Czech energy system and a change in the heat end price for residents, both - and mainly - the fact that the termination of extraction would be getting closer and we would have no proof that large heating plants are, in terms of fuel and technology, ready for major changes" (see Úřad vlády ČR \& Nezávislá energetická komise [ÚVČR\&NEK], 2008, p. 14).

In terms of energy security, it is not very reasonable to build new power and heating plants burning raw materials which the Czech Republic does not have at its disposal. These plants increase import dependence and costs, while they simultaneously reduce energy security. The Czech coal sector is capable of enhancing the energy security of the country, limiting foreign dependence on fossil fuels, supporting the stability of the electrical energy system, and all that under acceptable economic costs, while observing the requirements of protection of the environment and the fight against climate change. State decisions should serve to express a clear position, and not only to the private sector.

\subsection{The Heat Supply Industry ${ }^{62}$}

Heat supply can be provided through the means of central heating facilities (in which case we speak of the central heating supply system), as a result of a group (decentralized heating supply system) or individual (local production of heat). A developed central heating system is driven by cogeneration plants, rating plants and partially by the power plants in the regime of thermal mono-generation, but mainly in

60 The same way the use of coal will not cease in the world. Thermal power plants in China, for example, in 2008 made up $75 \%$ of installed capacity with 792,000 MWe. Between 2011 and 2015, China plans to build thermal plants with a total capacity of 270,000 MWe (see Hui, 2011).

61 Amount of extracted or produced fuel counted after the removal of ballast material.

62 The author of the subchapter is Petra Bendlová. 
the regime of combined production of power and heat, which then sells thermal energy further to external users in the production sphere or public sector (see Slivka et al., 2011, p. 10).

The central and decentralized heating supply systems satisfy the heat demand in the Czech Republic (approximately $330 \mathrm{PJ}$ ) practically on an even ratio. The central heating system distributes approximately half of its production to the public sector (households, services), while the other half goes to industry. The number of households supplied with thermal energy from the central system is up to 1.48 million (equal to $37.1 \%$ of the inhabitants in the Czech Republic) (see Slivka et al., 2011, p. 5, 6, 10-11).

In terms of sources (plants) of thermal energy, there are almost 2,000 facilities registered in the Czech Republic engaged in heat generation, 1,800 facilities with above $5 \mathrm{MW}_{\mathrm{t}}$ of capacity, and 17,000 facilities with 0.2-5 $\mathrm{MW}_{\mathrm{t}}$ of capacity. Four hundred central heating operators are part of the system of trading in emission allowances (see Slivka et al., 2011, p. 6, 10).

\begin{tabular}{|c|c|c|c|c|c|c|c|c|c|c|c|c|}
\hline \multicolumn{2}{|l|}{ Indicator } & 2000 & 2001 & 2002 & 2003 & 2004 & 2005 & 2006 & 2007 & 2008 & 2009 & 2010 \\
\hline \multicolumn{2}{|c|}{ Total production of thermal energy } & 827 & 844 & 872 & 952 & 953 & 931 & 944 & 977 & 934 & 881 & 911 \\
\hline \multicolumn{2}{|c|}{ Thermal energy consumed for power production } & 607 & 610 & 650 & 731 & 735 & 716 & 735 & 775 & 731 & 693 & 709 \\
\hline \multicolumn{2}{|c|}{ Net thermal energy production } & 220 & 234 & 221 & 220 & 218 & 215 & 208 & 202 & 203 & 188 & 202 \\
\hline \multirow[t]{8}{*}{ of which } & power plants and thermal plants & 150 & 161 & 153 & 152 & 149 & 148 & 141 & 140 & 140 & 131 & 143 \\
\hline & heating plants & 60 & 64 & 59 & 58 & 55 & 55 & 54 & 49 & 48 & 46 & 46 \\
\hline & nuclear power plants & 0.4 & 0.5 & 0.8 & 0.9 & 1.1 & 1.1 & 1.1 & 1.0 & 1.0 & 1.0 & 1.1 \\
\hline & combined cycle and cogeneration & 5.2 & 3.6 & 3.6 & 3.4 & 3.4 & 2.8 & 2.9 & 3.9 & 4.2 & 3.7 & 3.8 \\
\hline & chemical and waste heat & 4.7 & 4.6 & 5.7 & 6.5 & 9.5 & 8.6 & 9.2 & 8.1 & 6.9 & 6.1 & 7.8 \\
\hline & electrical boilers & . & . & . & . & . & . & . & . & . & . & 0.02 \\
\hline & solar systems & . & . & . & . & . & . & . & 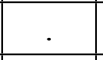 & . & . & 0 \\
\hline & thermal pumps & . & . & . & . & . & . & . & 0.1 & 0.1 & 0.1 & 0.1 \\
\hline \multicolumn{2}{|c|}{ Export of thermal energy } & 0.1 & 0.2 & 0.1 & 0.1 & 0.1 & 0.1 & 0.1 & 0.1 & 0,1 & 0 & 0 \\
\hline \multicolumn{2}{|c|}{ Losses in the distribution lines } & 16 & 17 & 21 & 21 & 20 & 21 & 19 & 18 & 19 & 18 & 19 \\
\hline \multicolumn{2}{|c|}{ Total consumption } & 203 & 217 & 200 & 200 & 198 & 194 & 189 & 184 & 184 & 170 & 182 \\
\hline \multicolumn{2}{|c|}{ Consumption during the fuel refinement process } & 12 & 9 & 9 & 10 & 10 & 9 & 10 & 9 & 13 & 12 & 13 \\
\hline \multicolumn{2}{|c|}{ Consumption during the fuel extraction process } & 4.7 & 5.2 & 5.6 & 5.0 & 4.9 & 4.1 & 5.3 & 5.6 & 5.1 & 4.3 & 4.2 \\
\hline \multicolumn{2}{|c|}{ Final consumption } & 186 & 202 & 186 & 185 & 183 & 180 & 174 & 169 & 166 & 154 & 166 \\
\hline \multirow[t]{2}{*}{ of which } & for production and operating process & 136 & 146 & 132 & 132 & 134 & 132 & 127 & 121 & 116 & 107 & 116 \\
\hline & households & 51 & 56 & 54 & 53 & 50 & 49 & 47 & 48 & 48 & 47 & 50 \\
\hline
\end{tabular}

The table clearly shows that net production of thermal energy has declined in the last 10 years. ${ }^{63}$ It is especially evident in the case of heating plants. On the other hand, renewables are starting to be employed more, although still not to a very significant degree. In the last two years (included in the table), the export of heat has ceased. Over time there has also been more successful management of losses in the distribution lines (due to better technologies). The consumption of thermal energy is also decreasing (we can assume

63 Between 1996 and 2000, in reality there was an even sharper decline of heat supplies intended for distribution in tens of PJ (see Český statistický úr̆ad, 2011b). 
as a result of greater heat savings, lifting of the thermal energy price and the switching of some users from central to decentralized heating systems).

Regarding the combined production of power and heat, central heat supply facilities have a $21 \%$ share in power production and a $39 \%$ share in heat production. The share of heat produced through the means of combined production of power and heat (in cogeneration) was $75 \%$ in 2010 . In 2008, there $11,406 \mathrm{GWh}$ of electricity and 123,455 TJ of heat was produced in 803 cogeneration facilities in the Czech Republic (see Slivka et al., 2011, p. 5; Bednář, Bufka, \& Rosecký, 2010, p. 4, 6, 11).

Fuels employed in the heating sector present $31 \%$ of all fuels consumed in the power industry (see Slivka et al., 2011, p. 5).

\begin{tabular}{|c|c|c|c|c|c|}
\hline \multicolumn{6}{|c|}{ Tab. 3.8: Fuel Mix for Production of Thermal Energy in the Czech Republic in 2010} \\
\hline Brown coal & Bituminous coal & Natural gas & Biomass & Fuel gas & Liquid fuels \\
\hline $50 \%$ & $10 \%$ & $11 \%$ & $16 \%$ & $12 \%$ & $1 \%$ \\
\hline
\end{tabular}

Source: Energostat, n.d (data of the Association of the District Heating of the Czech Republic); processed by P. Bendlová.

The total share of coal in fuels for heat production in 2010 was $60 \%$. As Slivka et. al. (2011, p. 14) argue, the share of domestic sources in the group of fuels within the central production of heat is $68 \%$, while the share of imported sources amounts to $32 \%$. On this basis we can conclude that there is (for now) rather low import dependence and thus significant raw materials security (as far as the heating sector is concerned). Related to the threat of shortage of primary sources in the Czech Republic, the question is what direction this indicator will take in the (already near) future.

The shares of fuels in heat production as part of the combined production of power and heat consist of $56 \%$ of brown coal, $21 \%$ of bituminous coal, $8 \%$ of natural gas, while other gases follow with $7 \%$, oils with $3 \%$, then $3 \%$ of biomass, $1 \%$ of biogas and $1 \%$ of other fuels (see Bednár, Bufka, \& Rosecký, 2010 , p. 5). As previously indicated, next to these fuels, other fuels are being reconsidered as well. According to Slivka et. al. (2011, p. 151-154), nuclear power plants, which could supply a broader area with thermal energy, have great potential.

It appears that by far the greatest, and so far unemployed, potential lies in the energy exploitation ${ }^{64}$ of mixed municipal waste ${ }^{65}$. Mixed municipal waste can be used for energy purposes within power and heat production facilities (combined cycle), whereas incineration plants are being connected to the central heating system. There are three incineration plants of mixed waste in the Czech Republic in Prague, Brno and Liberec (see Zajíček, \& Zeman, 2010, p. 27-29; Slivka et al., 2011, p. 114). In 2009, mixed municipal

64 The conditions which must be met in order to speak of waste-to-energy exploitation are de facto three: waste must burn by itself (aside from the ignition phase it does not require any fuel), generated heat must be used for one's own or other persons' purposes, and it has to reach a minimum of $60 \%$, or respectively $65 \%$ of energy efficiency (see Zajíček \& Zeman, 2010, p. 31).

65 Municipal waste, therefore all the waste emerging within a municipality during the activities performed by natural persons, and never natural or legal persons as registered entrepreneurs (see "Zákon č. 158/2001 Sb."), consists of used items and mixed municipal waste. Items which can be utilized anew (paper, glass, plastics, beverage cartons, etc.) are the first to be separated from municipal waste and then sent to recycling. Separation of waste in the Czech Republic is at a very good level, which is why the enormous amount of municipal waste actually cannot be lowered much further. Mixed municipal waste can be either sent to landfill sites or put into further use (by combustion in incineration plants and their energy exploitation). There is around 50 to $60 \%$ of biomass inside mixed municipal waste, while the calorific value ranges along the scale 8-15 (rather 9-11) GJ/ton (see Zajíček, \& Zeman, 2010, p. 25, 28, 37-38, 45). 
waste amounted to 3,236 kt, within which industrial waste made up $395 \mathrm{kt}$ (see Slivka et al., 2011, p. 108126). As Zajicek and Zeman (2010, p.26) argue, the percentage share of landfilling municipal waste is growing (ranging between 64 and $90 \%$ in recent years). In 2009, only $6 \%$ of municipal waste was employed for energy purposes, while in 2004-2008 it was $9 \%$ on average (see Česká informační agentura životního prostředí, 2011).

Installed thermal capacity in incineration plants in 2008 amounted to $175.7 \mathrm{MWt}$, while electrical capacity was only 2.9 MWe. The exploitable supply of heat ranged at the level of 2,500 TJ. The potential for further production is, however, much higher $-15,750 \mathrm{TJ}$ of heat and $0.5 \mathrm{TWh}$ of electricity per year (see Zajíček, \& Zeman, 2010, p. 39-40, 45). A waste-to-energy strategy can in that manner contribute to the use of domestic sources of energy and reduction of import dependence and simultaneously assist in solving the problem of waste landfilling in the Czech Republic.

The average price of thermal energy for end users in quotation localities with a prevalence of coal used for the production of thermal energy is $457.38 \mathrm{CZK} / \mathrm{GJ}$ (318 quotation localities), 568.49 CZK/GJ for quotation localities with a prevalence of natural gas (1012 quotation localities), $458.76 \mathrm{CZK} / \mathrm{GJ}$ for biomass (40 quotation localities) and 601.96 CZK/GJ for fuel oil (12 quotation localities) (see ERÚ, 2011e, p. 17-19). The price of thermal energy is by far the highest in the Liberec region, while the second most expensive is in the South-Moravian region. Both regions are also almost independent of coal supplies, since their share in heat generation makes up less than $5 \%$. The least expensive thermal energy is, on the other hand, produced in the Pardubice region, followed by the Hradec Kralove region in second place. Both regions benefit from the production of heat from coal, which is cheaper than natural gas, but on the other hand this also poses threats, as discussed below.

Among other fuels, the increasing share of biomass in the Vysocina region appears significant. If we were interested in price according to the type of source, the most important value is the price at which switching from a central to a decentralized heating system proves profitable. According to the Energy Regulatory Office, the competitive price of thermal energy for end users connected to the group central heating system should be counted as a price from house gas boilers amounting to $515.89 \mathrm{CZK} / \mathrm{GJ}$ with VAT included. If some group heating systems have a price of thermal energy higher than the above indicated limit, it can be expected that some users would choose to disconnect from the central heating system in order to achieve possible savings by building their own domestic sources of thermal energy (see ERÚ, 2011e, p. 3).

Heating plants and networks are usually the property of municipalities and the private sector in a 50:50 ratio. The largest producers (i.e. distributors) of thermal energy are companies which are in most cases owned by municipalities. Traditional producers of electrical power buying shares in various heating plants are, however, also struggling to enter the market. Some of the important companies engaged in the heat supply industry are, for example, Prazska teplarenska, Teplarny Brno, Plzenska teplarenska, Teplarna Ceske Budejovice or Teplarna Usti nad Labem (see “Teplárenství-Obchod a trh,” n.d.).

The central heating supply system in the Czech Republic has a number of advantages in comparison to other sectors, but also a number of disadvantages. There are also some threats involved, the potential realization of which could remove the advantages the heating supply industry currently possesses or even cause it to disappear as such.

The fact that production sources are localized outside residential areas is one of the primary advantages of central heating systems, having a positive impact in terms of the quality of city air and reducing the volume of polluting emissions in comparison with local heating facilities, and, in general, providing the possibility of better management and elimination of these emissions. By using domestic fuels (which are also less expensive), the heating industry achieves greater independence from imports and greater en- 
ergy security. As part of the combined production of power and heat, the heat supply industry is proven to utilize fuels better (efficiency up to $60 \%$ ) and is becoming more flexible. It also exploits renewable and secondary sources of energy. Demanding construction, loss of heat in distribution lines, more complex measurement, management and regulation and demanding adaptation to changes in terms of sales (mainly regarding thermal energy) appear as the major disadvantages (see Slivka et al., 2011, p. 20, 155).

There is, however, another realistic threat, which is the lack of domestic fuels that can be obtained for an acceptable price (primarily an issue related to brown coal). The termination of coal supply contracts is underway, mining is gradually declining, there is the uncertainty related to coal beyond the environmental limits of extraction, on the other hand, part of the available sources has not been distributed yet. In the case of a shortage of coal as a fuel, the lifespan of plants (not only thermal) lessens rapidly. The study by Slivka et al commissioned by the Ministry of Industry and Trade, moreover, warns of the weakness of substitution of coal with natural gas, biomass or coal imported from Germany and Poland, which come into consideration as alternatives (the weakness of such solutions lies in economic, disposable and security risks) (see Slivka et al., 2011, p. 20, 23, 155). The truth is that the greater the use of natural gas, the greater the dependence on external sources (quite probably the Russian Federation) which is unwanted, then the potential of biomass lies rather in decentralized and local heating systems, while the import of coal from abroad would lack economic profitability and it would erase the chief advantage of the central heating system, which is the local availability of sources.

A lack of coal would hit not only the production of thermal energy, but of electrical power as well. Both processes are, therefore, technologically and economically interconnected, so a shortage of coal as a fuel would affect the final score of both forms of energy as well as the prices and economics of heating plants. Accordingly, the present benefits of central heating supply could cease (see Slivka et al., 2011, p. 18-19). The Paces Commission finds the lack of fuel for heat supply systems to be one of the chief threats to the Czech energy economy (see ÚVČR \& NEK, 2008, p. 169).

Without long term contracts which would ensure supplies of fuel, the majority of centralized sources would be doomed to end, which would also lead to the breakup of the central heating system as such (see MPO, 2011b, p. 26).

The following tables present the forecast of the demand for bituminous (energy) and brown coals by 2050, respectively 2040 .

\begin{tabular}{|l|c|c|c|c|c|c|c|}
\hline Tab. 3.9: Forecast of Energy Bituminous Coal Demand \\
\hline Year & $\mathbf{2 0 1 0}$ & $\mathbf{2 0 1 5}$ & $\mathbf{2 0 2 0}$ & $\mathbf{2 0 2 5}$ & $\mathbf{2 0 3 0}$ & $\mathbf{2 0 3 5}$ & $\mathbf{2 0 4 0}$ \\
\hline Production of energy bituminous coal & 5,412 & 2,880 & 3,880 & 2,520 & 1,560 & 850 & 600 \\
\hline $\begin{array}{l}\text { Total demand of electrical power and heat supply indus- } \\
\text { tries }\end{array}$ & 3,900 & 3,780 & 3,180 & 4,170 & 4,160 & 4,090 & 5,500 \\
\hline Other demand & 300 & 250 & 250 & 250 & 200 & 200 & 200 \\
\hline Total demand & 4,200 & 4,030 & 3,430 & 4,420 & 4,360 & 4,290 & 5,700 \\
\hline Import-export balance & $-1,525$ & 150 & -450 & 1,900 & 2,800 & 3,440 & 5,100 \\
\hline $\begin{array}{l}\text { Note: data indicated in 1,000 tonnes } \\
\text { Source: Slivka et al., 2011, p. 44 }\end{array}$
\end{tabular}




\begin{tabular}{|l|c|c|c|c|c|c|c|c|c|}
\hline Tab. 3.10: Forecast of Brown Coal Demand according to EGU Brno \\
\hline Year & $\mathbf{2 0 1 0}$ & $\mathbf{2 0 1 5}$ & $\mathbf{2 0 2 0}$ & $\mathbf{2 0 2 5}$ & $\mathbf{2 0 3 0}$ & $\mathbf{2 0 3 5}$ & $\mathbf{2 0 4 0}$ & $\mathbf{2 0 4 5}$ & $\mathbf{2 0 5 0}$ \\
\hline Production of brown coal & 44,025 & 36,100 & 35,000 & 30,000 & 26,000 & 16,000 & 5,000 & 5,000 & 5,000 \\
\hline Future demand of CEZ & 26,530 & 29,230 & 21,100 & 16,600 & 12,550 & 11,700 & 4,700 & 4,700 & 4,700 \\
\hline $\begin{array}{l}\text { Future demand of independ- } \\
\text { ent producers }\end{array}$ & 13,535 & 13,085 & 13,465 & 13,235 & 11,880 & 7,940 & 4,340 & 3,830 & 3,830 \\
\hline $\begin{array}{l}\text { Future demand of other } \\
\text { users }\end{array}$ & 2,800 & 2,400 & 2,200 & 1,900 & 1,600 & 200 & 200 & 200 & 200 \\
\hline Possible export & 1,160 & 200 & - & - & - & - & - & - & - \\
\hline Total demand & 44,025 & 44,915 & 36,765 & 31,735 & 26,030 & 19,840 & 9,240 & 8,730 & 8,730 \\
\hline of which: for electricity & 32,316 & 32,968 & 26,986 & 23,293 & 19,106 & 14,563 & 6,782 & 6,408 & 6,408 \\
\hline for heat & 6,635 & 6,769 & 5,540 & 4,782 & 3,923 & 2,990 & 1,392 & 1,316 & 1,316 \\
\hline of which contracted & 44,025 & 42,810 & 35,370 & 28,000 & 24,210 & 15,930 & 290 & 200 & 200 \\
\hline $\begin{array}{l}\text { Difference between sources } \\
\text { and demand }\end{array}$ & $\mathbf{0}$ & $\mathbf{- 8 , 8 1 5}$ & $\mathbf{- 1 , 7 6 5}$ & $\mathbf{- 1 , 7 3 5}$ & $-\mathbf{3 0}$ & $\mathbf{- 3 , 8 4 0}$ & $\mathbf{- 4 , 2 4 0}$ & $\mathbf{- 3 , 7 3 0}$ & $\mathbf{- 3 , 7 3 0}$ \\
\hline $\begin{array}{l}\text { Difference between sources } \\
\text { and contracts }\end{array}$ & & $-6,710$ & -370 & 2,000 & 1,790 & 70 & 4,710 & 4,800 & 4,800 \\
\hline
\end{tabular}

Note: data indicated in 1,000 tonnes; For prediction of brown coal demand in 2015 (44,915,000 tonnes), an alternative lower calculation of demand has been processed, amounting to 40,885,000 tonnes. Inside the same forecast of brown coal extraction, the difference between supply and demand would fall to $-4,030,000$ tonnes.

Source: Slivka et al., 2011, p. 43.

As you can see, the production of brown and bituminous energy coal will practically not be able to cover the demand of the heating industry already from about 2015 (assuming no breaching of territorial environmental limits or nor that the heating system turns to other fuels). The difference between domestic coal production and demand will gradually increase over time.

Another significant problem of the Czech heating industry is the issue of the use of renewables as fuels. According to Slivka et al. (2011, p.8), the importance and availability of renewables as well as the savings on the side of consumption are significantly overrated. The potential of renewables in the Czech Republic is practically exhausted, especially in terms of wood cut-offs, while the use of wood cut-offs is in a competitive position in relation to its use in the paper and wood processing industry and local heating. Currently the only non-exploitable potential (believably 500,000 to 1 million tonnes by 2020 expressed in a brown coal equivalent) then lies in mixed municipal waste, which could partially replace classical fuels. The energetic potential of fuels from other waste is rather marginal with regard to the applicable legislation (primarily environmental limits - emissions, necessary modification of fuels would require purification of materials hazardous to health and the like).

The authors also perceive the mass use of the technology of thermal pumps for decentralized heating systems as unrealistic (see Slivka et al., 2011, p. 136-137). In this context, some projects are, however, already at the planning stage (in Litomerice, Decin, etc.) ${ }^{66}$, while the other sources claim that (given well-managed technologies, adequate soil and other favourable circumstances) geothermal power plants

66 See for example “Geotermální energie”, n.d. or Nachtmannová, 2005. 
(for decentralized heating system and local use) could prove profitable - for example, the technically available energy potential from hot dry rocks is 50,000 MW (see Myslil, Kukal, Pošmourný, \& Frydrych, 2007, p. 21). Biogas has recently been thriving as well.

Finally, artificial obstacles to the development, restoration of production and distribution capacities as well as the raising of public awareness and propagation which are pretty costly, but indispensable, and politics (primarily the as yet unapproved revised State Energy Concept) pose a problem of their own (see Slivka et al., 2011, p. 6-9, 20).

\subsection{The Issue of Extraction Limits}

Territorial environmental limits on brown coal mining are guided by Government Resolution No. 444/1991 on territorial environmental limits on brown coal mining in the North Bohemian Basin of October 30, 1991. This resolution specified the binding lines of limited mining and landfill in the quarries Merkur, Brezno, Libour, Sverma, Vrsany, CSA, Lezaky, Bilina and Chabarovice and in Ruzodolska and Radovesicka landfills as well as the limit values of air pollution in basins in the regions of Chomutov, Most, Teplice, Usti nad Labem and Louny (see Vláda České republiky [VČR], 1991). The idea behind these limits was to provide the regions with some sort of government guarantee that the city environment would not worsen and provide the inhabitants a stable grounds for local investment, reconstruction, etc. The topic of territorial environmental limits on brown coal mining has been appearing on the political scene for years now. The urgency of the issue, however, has been rising in relation to how close private coal companies are getting to these limits. In the next few years, they will gradually extract brown coal to its limits, and so the local power and heating plants will with great likelihood be without an inexpensive source of energy. That is the reason why they have from about 2003 started emphasizing (sometimes somewhat feverishly) the increasing risk of a power crisis, giant blackouts and collapses of power supplies.

The Government's position on the problem of extraction limits can be illustrated on the basis of its policy statements. In 2006, the Government declared that it would maintain the territorial limits on brown coal mining and that it would not pursue the construction of new nuclear blocks (see VČR, 2006, p. 13). In 2007, the Government once more declared that it would maintain the territorial limits on brown coal mining. Accordingly, it announced that it would not plan nor support the construction of new nuclear blocks and that it would, based on the consensus of all three political parties in the Government and after the consultation with the opposition, set up an Independent Expert Commission to assess the long-term energy needs of the Czech Republic (see VČR, 2007, p. 9). In the most recent policy statement of 2010, the Government announced that it would urge the maintenance of the territorial limits on brown coal mining and their legal specification, however, the Government gave notice of the proposal of a new mining act, which would set a condition of an economic exploitation of raw materials reserves. And this time, it did declare the support of the construction of new blocks to the Temelin nuclear power plant and modernization of the Dukovany nuclear power plant, including the associated transmission lines (see VČR, 2010, p. 37).

The above-mentioned Independent Expert Commission for assessment of the long term energy needs of the Czech Republic (the Pačes Commission) declared in 2008 that "... it was likely that the existing mining limits would be, sooner or later, breached as far as to the limits given by the geological stability of the region, because we produce electricity from brown coal at a cost of approximately $60 \%$ of the EU average and because emissions charges would not arrive before 2012. Disproportionately large-scale mining and the export of electricity was therefore, according to the Commission, profitable, accounting for approximately the equivalent of 20 million tonnes of brown coal per year, which would rapidly bring us 
closer to the limits and push the coal companies to breach them" (see ÚVČR \& NEK, 2008, p. 65). The Pačes Commission supported the government program, which did not recommend breaching the coal limits, but only pointed out that due to the trend in the Czech energy sector, mining beyond the limits should be expected sometime soon. In that context it also recommended considering whether to give an advantage to the use of local coal for the production of heat (see ÚVČR \& NEK, 2008, p. 65).

On the basis of standpoints on mining limits, the Czech political scene can be divided into three groups. The first group has an entirely clear stance in opposing the breach, consisting of the Czech Green Party, the Christian and Democratic Union - Czechoslovak People's Party and recently, based on their policy statements, also TOP 09 and the political party Public Affairs. The second group is, on the contrary, a proponent of the mining limits breach and mainly for social aspects in terms of unemployment in the region rather than for energy policy reasons. The representative of this group is the Communist Party of Bohemia and Moravia. Finally, the third group does not have a clearly defined stance, sometimes acting even entirely inconsistent, gathered around the Civic Democratic Party and the Czech Social Democratic Party.

It goes without saying that by far the greatest opponents of breaching the limits are, aside from the affected municipalities, environmental organizations. Their argument is based both on the potential perceived in renewables, decentralization, insulation and savings, diversification and cogeneration (see Polanecký, Rovenský, Sequens, Sedlák, \& Kotecký, 2009) as well as on legal aspects. Among other issues they point out that government resolutions are according to Competition Law binding and that the limits cannot just simply be breached (see Nezhyba \& Kotecký, 2006, p. 18). They also criticize that following approval of the resolution, the inventory write-off procedure was not executed, which is why it still counted on the coal beyond the limits (see Nezhyba \& Kotecký, 2006, p. 6-9). Some of the substantiated positions are that the potential breach of limits will not at any rate resolve the problem of the shortage of coal which the plants are experiencing, because it is for appropriation and other permit processes unrealistic to launch mining before 2023 (see Baroch, 2011b). The Academy of Sciences also expressed support for maintenance of the territorial environmental limits (see Komise pro životní prostředí Akademie věd ČR, 2010).

Breaching the brown coal mining limit is, or respectively was, to a certain degree an issue of greater importance for Czech politics than for the Czech energy industry as such. We can basically say that in the previous government a decision to breach the mining limits was blocked by the Czech Green Party and the Christian and Democratic Union - Czechoslovak People's Party. It, turned out however that removing the opponents of breaching of the mining limits from the Chamber of Deputies did not automatically mean its approval. It turned out that the Civic Democratic Party, a group with an unclear stance on this, came to agreement with the new coalition partners, Public Affairs and TOP 09, to vote against the breaching of territorial mining limits. The only opponent was the Communist Party of Bohemia and Moravia. It appeared that the stance of the three long-term strongest parties (the Civic Democratic Party, the Czech Social Democratic Party, Communist Party of Bohemia and Moravia) was in the final count in the period 2006-2010 rather inclined to approve breaching the limits. Whether the left or the right won the elections, decision making would mainly rely on the formation of government coalitions, on the political strength of smaller parties and on the general distribution of political power during the election period (see Černoch, Zapletalová, \& Vlček, 2010, p. 275).

The problem of the Czech coal (and, therefore, heat supply) sector lies not primarily in the territorial environmental limits on brown coal mining, but in the unpreparedness of users, including heating plants in the first place. They speak of basic uncertainty regarding the behaviour of mining companies and the future of coal prices. The mining companies, however, behave relatively predictably as they follow market principles. Coal arrives slowly, so the rise in its price is to be logically expected, since not even a twenty-year period from 1991, when the approval of the limits was passed, was sufficient for the majority of heating plants to prepare and replace their fuel bases. That means that unprepared heating plants have to 
buy coal, which plays right into the hands of the mining companies. They can afford not to prolong longterm contracts, which are mostly about to expire, and offer coal on the market on a short-term basis and in smaller volumes. It is, therefore, likely that mining companies will in this situation greatly benefit from setting the coal price on an auction basis. Moreover, if the heating plants do not buy coal, there are always steam power plants which are also interested in energy coal. At auction in May 2009, a tonne of several sorts of brown coal was sold for 1,696 CZK ${ }^{67}$, while the price of brown coal based on the place of origin, calorific value and category regularly ranges between 1,740 and 3,690, or respectively 5,000 (briquettes) CZK per tonne (see "Přehled cen", 2011). It means that auction trading has not raised the coal price at all.

The policy of not prolonging contracts with heating plants comes from the Czech Coal Group. It mines the coal in CSA Quarrel, which has the biggest volume of coal beyond the limits. Should the limits be maintained, the Czech Coal Group will be without coal in CSA Quarrel by 2021 and in Vrsany by 2058, while should the limits be breached, mining in CSA Quarrel will be prolonged until 2068 in the first stage, 2115 in the second and 2145 in the third phase (see Skupina Czech Coal). Both state companies, Severoceske doly, a.s., and Sokolovska uhelna, pravni nastupce, a.s., extract coal and through their owners accordingly own coal power plants and heating plants. On the one hand, they have sure sales of coal, while, on the other hand, they are not able to supply free coal to the market.

The Czech Coal Group refuses to prolong existing contracts with users, does not close new ones ${ }^{68}$ and offers its coal on the market in an effort to lift the price of coal as much as possible. Accordingly, it is struggling to acquire its own power plant or heating plant to increase the value of its coal. The biggest dispute is between the Czech Coal Group and the CEZ Group. The Czech Coal Group, originally Mostecka uhelna, a.s., terminated a contract on a future contract with CEZ to provide it with coal for the coming decades, which then led to the complaint of the CEZ Group (see Adámková, 2010a, p. 68). In 2009 the struggle to reach a solution out of court was interrupted by the European Commission's inspection for suspicion of possible manipulation of the market relevant for both companies in the form of the replacement of the CSA Brown Coal Basin for Opatovice power plant, which would resolve the problem of both subjects (see Adámková, 2010a, p. 69).

It would therefore be best to divide the entire issue into the territorial environmental limits on brown coal mining, the future of the coal sector, the heat supply industry and State Energy Concept on one side and the business strategies of Czech Coal Group, which deeply sank on the wave of territorial limits, on the other. Unfortunately, it seems that the Ministry of Industry and Trade to a degree has bowed before the lobbying pressure from the Czech Coal Group as well as from the Association for District Heating of the Czech Republic.

The shortage of coal is in the long term an issue which can certainly be resolved, for example, by imports, priority heat production, exploitation of biomass, development of nuclear power or the waste-to-energy method. It is unfortunate that the mentioned companies did not address this problem already in 1991 when the territorial environmental limits initially entered into effect.

67 Calculated as an arithmetic average.

68 The company's argument is that, due to the limits on mining from 1991, there is a lack of coal for all interested parties (see Adámková, 2010a, p. 68). 


\subsection{Coal War ${ }^{69}$}

The dispute in the Czech energy sector over coal for Czech heating plants has been the most pressing issue, and one greatly covered by the media, in the last couple of years. The quarrel was led by the Czech Coal Group ${ }^{70}$, represented by Pavel Tykac and Jan Dienstl, a trio of billionaire associates (Daniel Kretinsky, Petr Kellner (PPF) and Patrik Tkac (J\&T)), standing for Energy and Industry Holding (EPH) as the strongest actor ${ }^{71}$ within the Association for District Heating of the Czech Republic, and the parastatal CEZ group headed by Daniel Benes (by September 2011, by Martin Roman). The CEZ Group takes from Czech Coal approximately 8.5 million tonnes of coal per year, which represents a significant share of Czech Coal's overall production (14.15 million tonnes in 2011). ${ }^{72}$ The majority of this coal then goes to the Pocerady power plant near Most, the position and importance of which in the entire case will be addressed in the further text.

What is the nature of this Czech "energy clash of titans"? At first glance, it would seem like an effort of Czech Coal to press for higher prices of this energy source. Czech Coal demands that its coal be purchased for $70 \mathrm{CZK} / \mathrm{GJ}$ and accordingly to make the price of the Czech coal in the future directly tied to the price of coal offered on world markets, respectively to fix it at $80 \%$ of the average price of world coal. For comparison, the current purchase price of coal ranges around half of the price requested by Czech Coal. The Group, however, claims that a sharp growth in price is justified by the requirement to have the funds necessary for mining recommencement in case the current mining limits are removed. ${ }^{73}$

69 The author of the subchapter is Veronika Zapletalová.

70 The Czech Coal Group is represented as a trader in energy commodities, mainly coal, but it is striving to break into the power market and in the field of emission allowances trading. There are, however, two more mining companies in its stable. These are, namely, Vrsanska uhelna, a. s., which within our territory has the coal reserves with the longest lifespan, of course, within the existing territorial limits, and Litvinovska uhelna, a. s., which has the greatest coal reserves in the Czech Republic at its disposal. The activities of Czech Coal are, however, directed to reaching the heating industry, where the Group is present in several regional heating plants - see, for example, Teplarna Strakonice, a. s. and Vltavotynska teplarenska, a. s. Part of the Group is also he service company Czech Coal, a. s. In terms of ownership interest, in 2006, Pavel Tykac entered the Group as a co-owner through Indoverse Czech Investments Limited. In 2010, it took it over entirely (former co-owners Petr Pudil and Vasil Bobel left Czech Coal), while Jan Dienstl became a minority co-owner. Czech Coal, however, keeps the exact figure of Dienstl's share as a secret. At this point, the practical internal performance of the Group is run by the Chairman of the Board of Directors, Tomas Fohler, while the external dimension is controlled by Jan Dienstl, and strategic decisions remain the domain of Pavel Tykac. Pavel Tykac keeps his distance from media attention, long having lived in Switzerland (see "Bez zisku vydržime i deset let"). In 2013, several ownership changes have taken place -namely, the ownership of Litvinovska uhelna. Pavel Tykac in March of the same year separated this part from his imperium, while the company has been taken over by new owners, Jan Dienstl (50 \%) and Tomas Fohler (50 \%) (see Klímová 2013).

71 Energy and Industry Holding emerged in 2009 by the fusion of capital from strong investment groups. The Holding is further internally subdivided, where the energy activities are performed by EP Energy. Its stable gathers together Plzenska energetika, United Energy Trading, Elektrarny Opatovice, PEAS, Mibrag, Vetrne elektrarny Pchery, Prazska teplarenska, Aise, Powersun and United Energy (Energetický a průmyslový holding. Available at http://www.epholding.cz/ep-energy).

72 Even though brown coal mining by Czech Coal had been in decline during the entire previous decade, in 2011, extracted volume exceeded that from 2010 by 0.35 million tonnes. It is predominately Vrsanska uhelna that is responsible for this growth (see Czech Coal 2011).

73 In this context Jan Dienstl from Czech Coal said: "when the Government today approves the breaching, it will take us ten years before getting to the new coal. We need to pay the villages, which is six to eight billion CZK. We have to buy two or three sets of mining equipment, each for five billions. And we have to move 200 cubic metres of soil, a cubic metre for $70 \mathrm{CZK}$, which is 14 billion. In the course of ten years, we will, therefore, invest at least 30 billion CZK, without seeing a penny from it. When I go to the bank and tell them that we will sell 1 GJ for 40 or 50 CZK, the bank tells me: this will not pay off for you, lad, the price of coal must be higher" (see "Bez zisku vydržime i deset let"). 
This situation, naturally, met with strong disagreement from CEZ and the Association of District Heating, headed by EPH. They were highlighting the high gains which the Group had been generating on a long term basis and, in parallel, the excessiveness of the request to fix the price of coal at the level of world markets. In order to illustrate the wrongness of Czech Coal's decision, they mainly referred to the new contract which was closed in 2011 by Sokolovska uhelna, a. s. with its users - Plzenska teplarenska and Plzenska energetika. The former set the price of coal at $40 \mathrm{CZK}$ per GJ. The entire connotations was rather pungent also with regard to the fact that CEZ's long term contract on coal supplies expires by the end of 2012. The company had closed this contract exactly with Czech Coal.

Although CEZ's leadership (predominately during the period under Martin Roman) struggled to find an alternative solution ${ }^{74}$, without a compromise during 2012/2013, it would see disastrous consequences in terms of limited production in the already mentioned Pocerady coal-fired power plant. This power plant is entirely dependent on the Czech coal. Here we have keep in mind that just as Pocerady is dependent on coal, so are Czech Coal's sales of coal dependent on its use by Pocerady. Both sparring parties in that manner for a long time de facto remained in deadend while the pressure on both sides was rising followed by attacks from the media. "In case of further disagreement, we are prepared to limit mining, even at price of the temporary loss of every gain" is, for example, how Jan Dienstl reacted in March 2012 when asked where the present coal war could lead (see "Hoši z Motoinvestu roztáčeji kola").

Although it might seem so at first glance, the whole conflict initially was not just a dispute over a price. It was a dispute over redrawing the ownership map of Czech power plants. One of the options, often brought up in terms of the coal war, was an ownership merger of the Pocerady power plant and Vrsany Open Cast Mine. Czech Coal's notice of its interest in purchasing Pocerady took place during the talks with CEZ already in 2009. Czech Coal likewise expressed its interest in the power plant Chvaletice as well, which later in 2013 proved the key issue. The open cast mine's owner found this as a logical step, which would ensure a sale. ${ }^{76}$ As is be noted below, the holder of both power plants, CEZ, will in this case have to deal with EPH interests as well.

The rivalry between EPH and Czech Coal is accordingly related to another case. It was the sale of International Power Opatovice, which is the company encompassing both the power plant Opatovice as well as the heating plant Melnik and, in parallel, Prazska teplarenska. Czech Coal expressed an interest in the purchase, while the buyer, however, turned out to be a daughter company of J\&T Group (a shareholder in EPH which was then brought into to the newly emerging EPH structures), East Bohemia Energy Holding Limited. Although the decision to sell Opatovice came as early as June 2009, it was put on hold until the decision of the Office for the Protection of Competition, as a result of an initiative from Czech Coal. The argument was the suspicion that, following the purchase, J\&T Group might abuse its dominant position in the market. The Office, however, did not find this threat serious and the whole transaction had to be executed by 2009 . The transaction amounted to 22.5 billion CZK, which might seem rather overpriced when compared to the actual company's value. By completing this transaction, J\&T accordingly announced that $48.67 \%$ of Prazska teplarenska's stocks would in turn be sold to CEZ.

74 By a resolute increase of finances, the supplies for Pocernice might have been remediated from the North Bohemian Basins, owned by CEZ.

75 For illustration, let us, for example bring up the statement of Jan Dienstl on the matter of the dispute "(...) unfortunately, I have to admit this is already a war. It is being caused by Energy and Industry Holding (...)" (see Ibid) Rather tough words addressed to Czech Coal came from, for example, Daniel Kretinsky, who said that "Czech Coal has set off a car towards a wall driving at $200 \mathrm{~km} / \mathrm{h}$, it has another $30 \mathrm{~m}$ to go and it is clear it cannot pull up. Now it only hopes that someone will save it by quickly opening the doors" (see "Uhlazený akumulátor Daniel Křetínský") 
Czech Coal did not give up in its battle against EPH and CEZ and passed the investigation initiative to the European Commission. Specifically, Czech Coal complained that J\&T could have secretly bought International Power with the CEZ Group's money, because it alone did not have 22 billion CZK to take over the property, while the Office for the Protection of Competition would not allow CEZ itself to execute the purchase. The European Commission, therefore, in September 24, 2009, raided the HQs of CEZ, EPH and Severoceske doly. Phones and notebooks were confiscated from top managers, hundreds of documents were copied, while even the offices were sealed. ${ }^{77}$ According to some information, a couple of days prior to the raid, Czech Coal and CEZ held negotiations regarding the swap of the CSA Mine for the already several times mentioned Pocerady power plant.

After the raid, CEZ terminated the negotiations. In 2012, EPH was fined by the European Commission 2.5 million EURO (around 60 million CZK). The European Commission justified this penalty by the company's failure to cooperate with regulators during the raid in 2009 and, therefore, provide them with relevant documentation. According to the Commission, the company during the inspection did not block the e-mail account, it did not disclose protected e-mails and it re-directed incoming e-mails (see "Co stojí za razií, za kterou zaplati EPH pokutu?"). ${ }^{78}$ The initial investigation of the European Commission regarding the purchase of International Power is, however, still in progress.

The coal war is for EPH also a very personal matter since it uses for its power plant in Opatovice, obtained by means of the earlier mentioned purchase of International Power Opatovice, precisely coal from Most. The long term contract of this power plant was supposed to expire in 2015. On July 7, 2012, the Czech Coal Group, however, cancelled the contract because of an alleged debt of 500 million CZK. The Regional Court in Usti nad Labem, nonetheless, concluded that Czech Coal Group had to continue with power supplies and at least for a year, which is until the end of 2013 (this provision is a part of the contract) (see Vlček-Černoch, 2013, p. 467). After this date, from the second half of 2013 Opatovice does not have ensured coal supplies.

If it does not reach a compromise with Czech Coal, $\mathrm{EPH}$ is looking around for alternative suppliers and not only within the Czech market. One of considered solutions is even to import coal from the German Mibrag mine, which is a part of EPH's property. Daniel Kretinsky said regarding this option, for example, that although it was financially exacting, if Czech Coal's position stayed unchanged and it set the price at 70 CZK per GJ, coal imports from Germany would prove financially affordable. ${ }^{79}$ According to Jan Dienstl from Czech Coal, EPH's unwillingness to accept an increase in coal prices may be based on its desire

77 There was considerable speculation as to whether the European Commission's move was unexpected and efficient. It was revealed that the subjects were previously informed about the raid, so that some data was, consequently, removed beforehand.

78 Two events contributed to the procedural irregularities. In one case, an employee, which was not informed about the blockade of electronic e-mail (the European Commission itself admitted it was a matter of negligence), had signed in to his or her e-mail account which was the subject of the inspectors' examination. In the second case, another employee already during the second inspection day - following a discussion with an inspector regarding the range of disclosure of his or her personal and business e-mail, was supposed to stop storing all incoming mail on the server and not on the personal computer (see "Brusel udělil EPH pokutu”).

79 When asked whether it is realistic to consider coal imports from Mibrag, Kretinsky said that "although it might seem absurd, and it would be under normal conditions, but given the prices Czech Coal is now offering us and current transportation costs, it should certainly be considered. We, however, have several options, but I cannot speak in more detail about them. In principle, it would encompass a combination of three measures - we will strive to reduce coal consumption at the level of EPH, coal can be obtained from some independent traders still existing on the Czech market, while potential imports are the third measure” (see "Uhlazený akumulátor Daniel Křetínský"). 
not to lose a cheap source of profit from power production. "EPH," he continues, "does not wish to come to the settlement between the miners and power industry, involving a notable aberration working in the producers' favour." EPH, naturally, inherently disagrees with this statement. ${ }^{80}$

When speaking of the dispute between these energy titans, we should also mention another issue related to the abovementioned events. In 2011, Czech Coal reported CEZ to the European Commission for an administrative proceeding. The European Commission suspected CEZ was accumulating capacities in the transmission system in order to prevent the competition entering the market. CEZ was specifically suspected of reserving such great capacity for connection of its power plants with the operator of the Czech transmission system CEPS so the other projects could not receive their share from CEPS. Czech Coal in that manner tended to leave the impression that the speculative circumstances prevented it from developing its own project involving the construction of a coal-fired power plant in Pocerady (see "Czech Coal poskytl Evropské komisi podklady"). CEZ defends itself by arguing that it reserved the capacity for the construction works on the combined cycle power plant in Pocerady, which was initiated in March 2011. According to recent estimates, Czech Coal wants to connect its power plant to the network by 2021. With that in mind, at the end of 2011 it closed a contract with CEPS for allocation of $660 \mathrm{MW}$ of capacity.

Links between the Czech political scene and the energy business are not new. In case of the coal war, for example, it showed up in the nomination of the former Prime Minister, Mirek Topolanek, as Chairman of the Association of District Heating. ${ }^{81}$ Topolanek, who was proposed for this post on behalf of Opatovice power plant (EPH), currently a member of its Supervisory Board, had replaced the former Chairman of Teplarny Brno, Alexej Novacek, whereas his selection provoked a range of emotional reactions. Specifically, it was spoken about in terms of the long term bonds between EPH (having the dominant position within the Association for District Heating), respectively its co-owner the J\&T Group, and the former Prime Minister. ${ }^{82}$

Immediately after his nomination, Topolanek actively began lobbying against Czech Coal's efforts to increase the price of coal. Topolanek was then pointing out the need for a thorough investigation of the situation in the brown coal market both by the Office for the Protection of Competition, the Government of the Czech Republic ${ }^{83}$ and finally by the European Commission (see "Teplárenské sdružení nadále odmitá"; "Křtínského EPH má na nové investice"). The Association for District Heating then at the be-

80 Jan Dienstl specifically argued that "for now it functions in the manner that we supply Opatovice power plants with 1.8 million tonnes of coal per year for the lowest price in the entire Republic. They take 600,000 tonnes of it and during the heating season heat Pardubice and Hradec Kralove at $60 \%$ efficiency. This is perfectly fine. When we raise the price of coal from today's $31 \mathrm{CZK/GJ}$ to about $70 \mathrm{CZK} / \mathrm{GJ}$, if the heating plant wishes to preserve the current profit, the price of thermal energy for inhabitants will go up by a maximum $20 \%$. This is still not a tragedy. The problem of Opatovice is that they will have to stop burning that 1.2 million tonnes of remaining coal, which they use out of the heating season for power production via condensation, at only $18 \%$ efficiency. This is what currently brings them 650 to 700 million per year. And this is the core of the whole dispute, this is the incentive for all this noise and lawsuits. If I lift the price of coal, they will start losing on electricity. I see this also as a national economic and political issue. Someone should ask them if it is even thinkable to burn coal at such a low efficiency and practically "heat the water in the Elbe river". The parallel production of heat and electricity makes the combustion efficiency incomparably higher" (see "Uhlazený akumulátor Daniel Křetínský."; "Bez zisku vydržime i deset let”).

81 The Association for District Heating is an interest group of legal entities doing business in the field of heating supply, founded in 1991 and currently consisting of 89 members.

82 A link between Topolanek and J\&T was implied already during the so-called Tuscan affair, during which high political officials were photographed on a joint vacation with the top representatives of J\&T.

83 Immediately after his selection, Topolanek started calling for expedited state intervention into the whole matter. Specifically, in March 2012, he said that "the state would be certainly able to prevent a situation in which a mining company intentionally limits mining in order to induce a shortage of coal on the market and lift the price. In that sense, a change in The Mining Act and establishment of sanctions for that kind of behaviour would be appropriate" (see "Stát se musi"). 
ginning of 2012 filed a claim to the latter, arguing that Czech Coal held a dominant position in the brown coal market and therefore employed such circumstances to manipulate the prices of that material (see “Teplárny si v Bruselu stěžuji””).

As the previous lines show, the situation in 2012 was rather chaotic, giving little chance to predict its further development. Everything however changed at the very end of 2012 when it started to become clear that Czech Coal would come to an agreement with the parastatal CEZ. The agreement closed in 2013 has additionally confirmed this trend.

Its provisions are as follows: the price of coal for the Pocerady power plant will be fixed and its maximum will not reach $40 \mathrm{CZK} / \mathrm{GJ}$. The agreement, however, anticipates a linear growth in price as far as to 2023. That is basically the last year of the power plant Pocerady's lifespan. The latter could be enhanced at best through the power plant's modernization. Based on the contract, CEZ has two options for selling the power plant to Vrsanska uhelna, that is to Czech Coal. Sale may take place either in 2015/2016 or in 2024. The latter option, however, means that the modernization would be implemented by CEZ alone. The price of coal for the new Pocerady would at that point appear entirely different and it would be derived based on the ARA index. It would start at $65 \%$ of the ARA index and consequently rise to the full level of the ARA index. The contract does not include the claim of Vrsanska uhelna/Czech Coal to purchase the Pocerady power plant (see Motejlek, 18/3/2013). ${ }^{84}$

The agreement between Czech Coal and CEZ has accordingly paved the way for further business, even though both contracts were presented as mutually independent. Specifically, this is the sale of the Chvaletice brown coal power plant. During 2012, only a few people could expect that Czech Coal would get this power plant (the sale price of Chvaletice ranged at the level of 4.12 billion CZK) and not EPH. At this point, it is clear that the previous decent partnership between CEZ and EPH is coming to an end. Daniel Kretinsky on behalf of EPH comments on this purchase in the most negative manner and emphasizes that it will lead to an even greater distortion of the Czech market. It is definitively EPH who will in mid-2013 get the short end of this dispute, which naturally has a negative impact on the leading position of Kretinsky in the Holding.

84 Upon closure of the coal contract, the present Chairman of CEZ, Daniel Benes, did not hide his dissatisfaction with how things were developing. "If it would by any chance happen that a private individual owned a mine, I would have to accept it as it is. Personally, I will never accept that mines are not in the state's hands. So, if already someone owns a mine and you have a power plant next to it, you have no other option but to come to agreement with that person," he said. "The measure of animosity towards Czech Coal was so high that the agreements closed were the strongest, the most robust and set with the greatest measure of mistrust in the opposite party that I have ever seen in this area. You will nowhere else see such contract going as far as predicting how one side might cheat the other. For example, if they did not want to supply us with coal," Benes said as well. The contract, according to him, includes a security deposit "in order to be sure that, in the event Czech Coal does not provide us with coal, we can at least get hold of this money". According to the Chairman of CEZ, a security deposit amounts to billions of CZK and it has been already deposited (see Němeček, 8/4/2013). 


\section{Chapter 4: The Oil Sector ${ }^{85}$}

Tomáš Vlček

\subsection{Introduction}

The Czech Republic enjoys diversified oil supply routes via the Druzhba and IKL pipelines. Already in 1962, the first oil supplies flowed in the Czechoslovakia through the primary pipeline, routing from the Soviet Union through the southern branch of the longest pipeline in the world - Druzhba. The Druzhba pipeline was the first pipeline operating on Czech territory. The Druzhba pipeline was brought down to Bratislava in 1962 (present Slovakia) and extended to Zaluzi u Mostu (now Litvinov-Zaluzi in the Czech Republic) in 1965. In 1990, the Adria pipeline was launched in the south-western part of Europe, "ready" already since 1984 and built as a joint venture of the Former Yugoslavia, Hungary and the Czechoslovakia. Soon after, the pipeline, however, showed a lack of capacity and there was, furthermore, a real danger in the future threatening to exclude the Czechs from its offtake as a result of increasing oil offtake by Slovakia and Hungary. With regard to this problem and issues emerging in the oil companies in Russia and the subsequent potential troubles with oil supplies via the Druzhba pipeline, in 1990-1992 it was decided to build another pipeline route, the IKL pipeline (Ingolstadt - Kralupy nad Vltavou - Litvínov) (see MERO $\check{C} R$, a. s.). The IKL pipeline (Ingolstadt - Kralupy nad Vltavou - Litvinov) started up on March 13, 1996. The Druzhba pipeline provides the Czech Republic with 60-70 \% of its import volume, while the remaining $30-40 \%$ is supplied through the IKL pipeline (for more details, see Table 4.1).

\begin{tabular}{|c|c|c|}
\hline \multicolumn{3}{|c|}{ Tab. 4.1: Pipeline Routes in the Czech Republic } \\
\hline & Druzhba & IKL \\
\hline Start of Supply & 1962 (Slovakia), 1964 (Czech Rep.) & 1996 \\
\hline Transport Capacity (Mt/y) & 9 & 10 \\
\hline Supply Volume (Mt, 2008) & 4,808 & 3,300 \\
\hline Percentage Rate $(\%, 2008)$ & 59.3 & 40.7 \\
\hline Supply Volume (tonnes, 2009) & 5,011 & 2,179 \\
\hline Percentage Rate $(\%, 2009)$ & 69.7 & 30.3 \\
\hline Supply Volume (tonnes, 2010) & 4,536 & 3,192 \\
\hline Percentage Rate (\%, 2010) & 58.7 & 41.3 \\
\hline Utilization ( \%, 2008/2009/2010) & $53.42 / 55.68 / 50.4$ & $33 / 21.79 / 31.92$ \\
\hline Source & Russia & $\begin{array}{c}\text { Algeria, Azerbaijan, Italy, Kazakhstan, Libya, } \\
\text { Nigeria, Norway, Russia, Syria }\end{array}$ \\
\hline Pipeline Transit Countries & Russia, Belarus, Ukraine, Slovakia & Italy, Austria, Germany \\
\hline \multicolumn{3}{|c|}{$\begin{array}{l}\text { Note: The route of the south branch of the Druzhba pipeline, which transports supplies to the Czech Republic, crosses Al } \\
\text { metevsk - Kuybyshev - Unecha - Mozyr - Brody - Uzhhorod - Sahy - Litvinov. Also, crude oil coming from Russia is no } \\
\text { necessarily Russian. } \\
\text { Source: Ministry of Industry and Trade, 2009d, p. 1, Czech Association of Petroleum Industry and Trade, 2010, p. 8; „Druzhba } \\
\text { Pipeline“, 2009, p. 56; Ministry of Industry and Trade, 2011, p. } 15\end{array}$} \\
\hline
\end{tabular}

85 The chapter in some parts makes reference to the publication of the research project The Future of the Druzhba Pipeline as a Strategic Challenge for the Czech Republic and Poland (see Černoch, Dančák, Kod'ousková, Leshchenko, Ocelík, Osička, Šebek, Vlček, \& Zapletalová, 2012) and the document Current Issues and Projects in the Field of the Storage and Transportation of Oil to the Czech Republic (see Vlček, \& Černoch, 2013). 


\subsection{Deposits, Production, Companies and Traders}

The Czech oil market can be vertically divided into five levels. At the top is international carrier oil, below this level are the processing plants, at the third level is the distributor and finally the lowest level is composed of traders in crude oil and oil products. Outside these four there is a fifth level, which can be placed somewhere between international carriers and processing plants. On this level are Czech production companies, whose share of the oil supply is too small to affect the integrated structure of the remaining four levels.

\subsubsection{Deposits and the Production of Oil in the Czech Republic}

There are no significant oil resources in the Czech Republic, and oil is produced only at small deposits in the Vienna Basin and in the Carpathian Fore deep in South Moravia. Deposits of oil are mostly tied to natural gas deposits. Domestic production accounts for two to four per cent of the volume of oil supplied to the Czech Republic over the long-term.

\begin{tabular}{|l|l|c|c|c|c|c|c|}
\hline Tab. 4.2: Deposits, reserves and oil well production of oil in the Czech Republic \\
\hline & $\mathbf{2 0 0 5}$ & $\mathbf{2 0 0 6}$ & $\mathbf{2 0 0 7}$ & $\mathbf{2 0 0 8}$ & $\mathbf{2 0 0 9}$ & $\mathbf{2 0 1 0}$ & $\mathbf{2 0 1 1}$ \\
\hline Deposits - total number & 28 & 28 & 28 & 30 & 33 & 34 & 33 \\
\hline - exploited & 19 & 21 & 22 & 24 & 27 & 27 & 27 \\
\hline Total mineral reserves & 32536 & 32277 & 31118 & 31144 & 31031 & 29015 & 30891 \\
\hline - economic explored reserves & 12526 & 12315 & 14602 & 15553 & 15440 & 15424 & 20326 \\
\hline - economic prospected reserves & 8613 & 8609 & 5163 & 5113 & 4482 & 4475 & 3983 \\
\hline - potentially economic reserves & 11397 & 11353 & 11353 & 10478 & 11109 & 9116 & 6582 \\
\hline - exploitable (recoverables) res. & 2325 & 2135 & 1793 & 1718 & 1535 & 1415 & 1664 \\
\hline Oil well production & 306 & 259 & 240 & 236 & 217 & 173 & 163 \\
\hline $\begin{array}{l}\text { Note: reserves in kilotonnes (kt). } \\
\text { Source: Ministerstvo životního prostředí / Česká geologická služba - Geofond, 2010, p. 185; Ministerstvo životního prostředí } \\
\text { / Česká geologická služba - Geofond, 2012, p. 96. }\end{array}$
\end{tabular}

There are three oil-producing companies in the Czech Republic: MND, Ceska naftarska and UNIGEO. MND, Hodonin, was formed by transformation of the state enterprise MND Hodonin, s.p. in 1992. Since July 2010, it has been $100 \%$ owned by the KKCG group of the entrepreneur Karel Komarek, whose parent company KKCG SE is based in Cyprus. The company holds 68 production and two exploration licenses for Moravia and holds exploration licenses in the Russian Federation, and it also operates in Germany, Romania, Slovakia and recently also in Poland (see MND; Rybová, 2010). Ceska naftarska, Hodonin, is a sister company of LAMA INVESTMENT (Hradec nad Moravici) within the LAMA group. The company holds an exploration license and a production license. Since 2006 it has been producing around $91 \mathrm{t} / \mathrm{d}$ of oil and gas at the Postorna deposit in the production area Charvatska Nova Ves near Breclav (see Ceska naftarska). UNIGEO, Ostrava-Hrabova, which is $100 \%$ owned by the Kooperativa insurance company, has been extracting oil since 2003 from a single oil deposit, Krásna pod Lysou horou, in the Moravian-Silesian Beskids. Oil is exported to Polish refineries (see UNIGEO). 


\subsubsection{International Carrier Oil}

The exclusive operator of international oil pipelines in the Czech Republic is MERO. The company, based in Kralupy nad Vltavou, owns and operates the Czech part of the Druzhba and IKL pipelines. It is the only carrier of oil to the Czech Republic and the most important company providing emergency storage of strategic oil reserves. MERO is the $100 \%$ shareholder in a subsidiary company MERO AG based in German Vohburg on the Danube, which operates and maintains the IKL pipeline in Germany and a crude oil tank in Vohburg with a total volume of 200,000 cubic metres. The $100 \%$ owner of MERO is the Ministry of Finance. The company also owns and operates the Central Crude Oil Tank in Nelahozeves with a capacity of 1,550,000 cubic metres, where the operational and strategic reserves for the Administration of State Material Reserves are stored (see Zaplatílek, 2007, p. 69).

The total length of the Druzhba pipeline is 3,840 km (see "Druzhba Pipeline", 2009, p. 56). The Druzhba pipeline on Czech territory has a maximum throughput capacity of $9 \mathrm{Mt}$ of oil annually. It is $357 \mathrm{~km}$ long in the Czech Republic, the pipe diameter is $528 \mathrm{~mm}(700 \mathrm{~mm}$ in the Moravian part) with a flow rate of oil of 1-1.4 m/s (see MERO CR). The pipeline brings oil from the Russian regions of Western Siberia and the Volga-Urals.

The IKL pipeline has a maximum throughput capacity of $10 \mathrm{Mt}$ a year. It is $169.7 \mathrm{~km}$ long in the Czech Republic, and the pipe diameter is $714 \mathrm{~mm}$ with a flow rate of 0.5 to $1.2 \mathrm{~m} / \mathrm{s}$. The total length of pipeline from Vohburg to the Central Crude Oil Tank Nelahozeves CCOT is $349 \mathrm{~km}$ (see MERO CR).

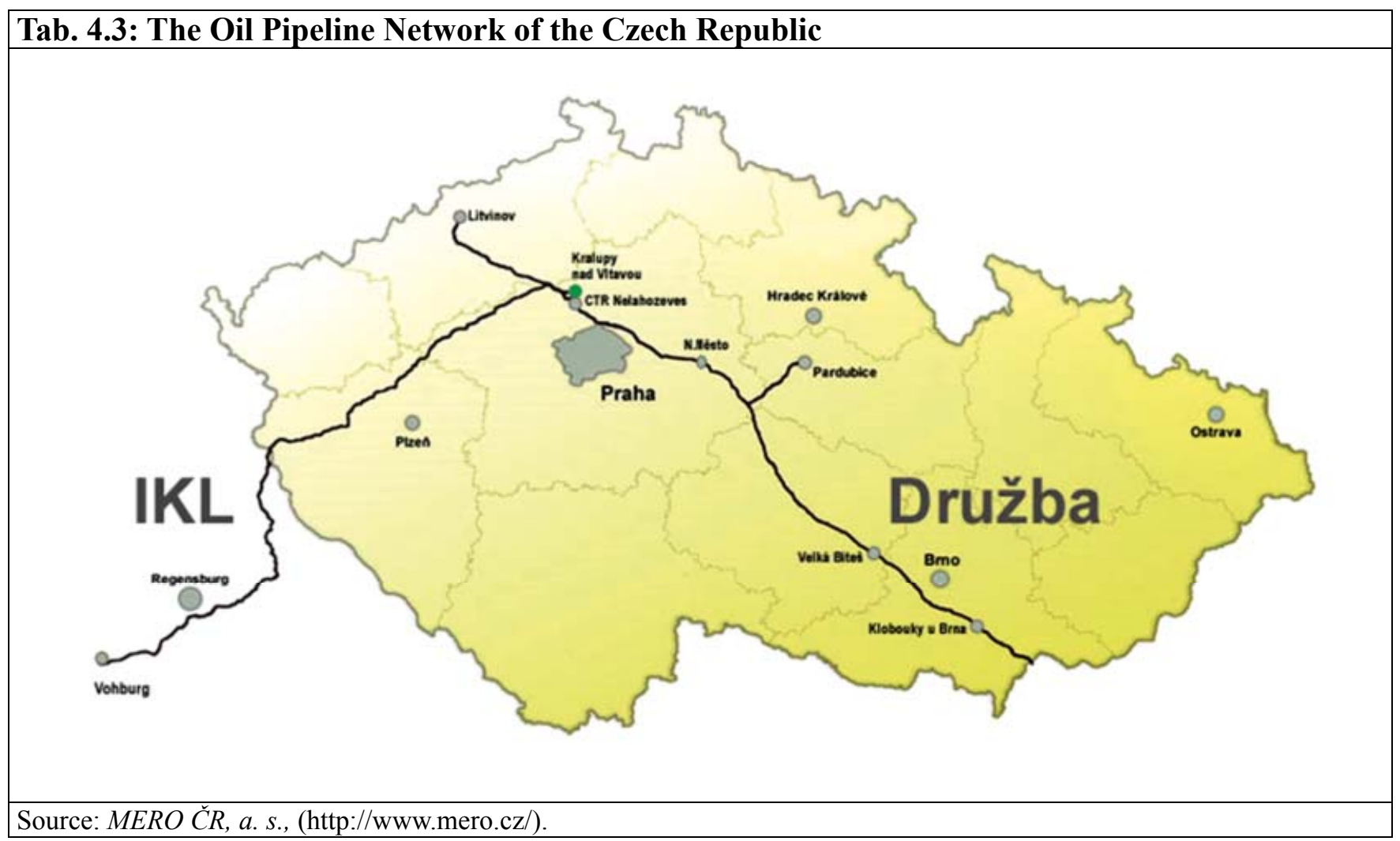

MERO CR is the sole provider of transportation services for oil to the Czech Republic. It does not own any oil. Processor plants realizing contracts with crude oil suppliers have to also arrange transport contracts with MERO CR. This company provides its services based on tariff charges fixed in the long-term contract 
with the oil processor. It also provides free capacity of oil products pipelines to transport crude oil or oil products outside of long-term contracts. Oil is traded under long-term (up to five year) contracts, quarterly and on the spot market (i.e. monthly), while about half of demand is supplied through spot transactions.

\subsubsection{Processing Plants}

There are two processing companies in the Czech Republic - Ceska rafinerska and Paramo. Each is divided into two more oil refineries that make up the four oil refineries in the Czech Republic. ${ }^{86}$ They processed 7.41 Mt of oil in 2009 and 7.90 Mt in 2010 (see MPO, 2011, p. 3).

Ceska rafinerska, based in Litvinov, is the largest producer of crude oil and processor of oil products in the Czech Republic. It operates oil refineries in Litvinov and Kralupy nad Vltavou. It processed 7.65 Mt of oil in 2008, which is a record in the company's history. The refinery processed $2.27 \mathrm{Mt}$ of oil in the Kralupy nad Vltavou refinery, and 4.56 Mt of oil in the Litvinov refinery giving a total of $6.83 \mathrm{Mt}$ of oil in 2009. In 2010 it was 7.37 Mt (2.69 mil. metric tonnes in Kralupy nad Vltavou and 4.86 mil. metric tonnes in Litvinov) (see Ceska rafinerska, 2009, p. 4, Ceska rafinerska, 2010, p. 4, Ceska rafinerska, 2011, p. 5). Ceska rafinerska, is a joint venture of Unipetrol ${ }^{87}$ (51.22\%; see Unipetrol a.s.), the Italian company Eni International B.V. (32.45 \%) and Royal Dutch Shell through its subsidiary Shell Overseas Investments B.V. (16.33\%) (see Ceska rafinerska, 2010, p. 24).

Ceska rafinerska is a reprocessing refinery, which focuses only on the production of oil products, and not the purchase of resources and sale of oil products. The oil reprocessing refinery is supplied with crude oil by its shareholders through their trading companies - the processors. These are Eni CR, Shell Czech Republic and Unipetrol RPA in the case of Ceska rafinerska. A refinery operating in reprocessing mode processes the supplied oil at the request of processor into high-quality oil products. The refinery receives a processing fee for this activity, which is both linked to the installed refinery capacity (including staff costs and other fixed costs) and is also derived from the volume of processed oil, as well as the consumption of energy and other variable costs. A processing fee paid by each processor is the only refinery income (see Ceska rafinerska, n.d.). The key to the refinery business is the refining margin (the difference between the price of crude oil and of petroleum products), and according to company information it varies from 2.2 to 4.4 euro per barrel. The shareholders cover the costs of refinery operation from this margin, namely the "processing fee" relative to the amount of oil processed. The amount of oil for reprocessing is dependent on the size of the shareholder's stake. The supplies of oil are dictated by the processor's business contracts.

Ceska rafinerska is supplied with oil via the Druzhba and IKL pipelines (via the Nelahozeves central crude oil tank). The refinery complex is supplied with small volumes of oil extracted by Moravské naftové doly in the Czech Republic via the Druzhba pipeline. The refinery in Litvinov processes the Russian oil mixture REB (Russian Export Blend - medium sour oil imported from Russia via the Druzhba pipeline in particular), while the refinery in Kralupy processes sweet oil, low sulphur crude oil that is imported into the Czech Republic via the IKL pipeline (Ingolstadt - Kralupy - Litvinov) and domestic oil extracted by Moravske naftove doly a.s. (see Ministry of Environment / Czech Geological Service - Geofond [ME / CGS-G], 2009, p. 180). Products after the processing of crude oil are then distributed based on instructions

86 The Koramo plant owned by Paramo does not process crude oil but mainly produces motor oils by mixing the input components - base oils and additives. Only diesel fuel was produced in Paramo, but its production has been phased out since May 2012.

87 Unipetrol shareholder structure $-62.99 \%$ is owned by Poland's PKN Orlen and $37.01 \%$ is composed of publicly traded shares (see Unipetrol). 
from processors to Czech or foreign markets via state-owned CEPRO (see below) oil products pipelines. Refinery products of Ceska rafinerska are for example aviation kerosene, automotive petrol, sulphur, LPG, heating oil, diesel, propylene, asphalt, hydrogenated oil and various intermediate products for further processing in the Litvinov refinery.

Paramo (Pardubice refinery of mineral oil) based in Pardubice operates two plants, one in Pardubice and the other in Kolin. The company processed 0.55 Mt of oil in 2009 and $0.53 \mathrm{Mt}$ in 2010 (see Paramo, 2010, p. 11; Paramo, 2011, p. 7). Since March 2009 it has been wholly owned by Unipetrol. At the same time Paramo wholly owns Mogul Slovakia based in Hradiste pod Vratnom, which deals in buying and selling oils and lubricants in Slovakia.

Paramo focuses on refining crude oil into refinery and asphalt products and on the production of lubricating and processing oils, including related and auxiliary products. The company also buys and processes hydrogenated oil from Unipetrol RPA. The acquired intermediate products are used in the production of base and lubricating oils with very low sulphur content (see Paramo, 2010, p. 10). The refinery products of Paramo are motor fuels, heating oil, asphalt and other asphalt products, lubricating oils and greases. The company operates a fuel refinery in Pardubice that is engaged in the processing of Russian crude oil primarily for fuel, lubricating oil and asphalt. It also operates a smaller branch in Kolin, which is operated as an oil refinery to produce lubricating oil (see ME / CGS-G, 2009, p. 180). In May 2012, the management of the company in Pardubice stopped the processing of oil meant for fuel production and turned to the production of asphalt, oils and lubricants. The main trading partner in refinery products in the period in question was the sister company Unipetrol RPA, to which supplies of primary petrol and vacuum distillates went (see Paramo, 2010, p 11). The future of Paramo refinery is not clear as Unipetrol's management is considering closing the plant due to falling demand for asphalt — principally the result of sharp cutbacks in Czech government funding for road-building - and low prices for the material compared to oil prices. Unipetrol decided to close operations in Paramo in December 2011, but in March 2012 all operations were restarted. In 2010, Paramo recorded a €7,5 million loss.

\subsubsection{Distributors}

The products are distributed after processing. Petroleum products are both material for other technologies in the petrochemicals, agrochemicals and plastics industries, and are also taken out directly from the refineries' shipping terminals by end customers or various distributors. This is particularly true for sulphur, LPG, bitumen, fuel oil, jet fuel and also for normal fuel. CEPRO is the exclusive distributor through product pipelines in the Czech Republic. The Ministry of Finance has been the sole shareholder in the company since 2006. It is engaged in the transport, storage and sale of oil products; providing transport, storage and other specialized services in this area to external entities; protection of the Administration of State Material Reserves (ASMR) and operating the EuroOil petrol station network (see CEPRO, 2010, p. 4).

The oil products pipeline system connects the company's CEPRO storage depots and centres with refineries in Litvinov, Kralupy nad Vltavou and Bratislava (owned by the Slovak company Slovnaft). The system allows direct pumping and supply between its various depots. CEPRO central dispatch monitors the operation of oil product pipelines, monitors basic technical operational parameters (e.g. quantity of supply in the centres, pumping modes) and data from security systems (see Zaplatílek, 2008). Due to the nature of the oil products produced in Pardubice and Kolin (asphalt products, oils, etc.) there is no entry point into the system of oil product pipelines in these refineries. The company is primarily engaged in the transportation of oil products according to the customer's needs (through the oil product pipelines, rail tankers, tank trucks and trucks) and the wholesaling of fuel. 


\subsubsection{Traders in Oil Products}

The last level consists of oil product traders. The most important ones in the Czech Republic are Unipetrol, BENZINA (a subsidiary of Unipetrol), Shell Czech Republic, OMV Czech Republic, EuroOil, Eni Czech Republic, RoBIN OIL and LUKOIL Czech Republic.

Unipetrol is a subsidiary of PKN Orlen (Polski Koncern Naftowy Orlen) and is an important player in the Czech oil market. Unipetrol, headquartered in Prague, covers a group of twenty companies and as of 30th April 2010, in terms of revenue, the company ranked sixth in the Czech Republic. In addition to the processing of crude oil in refineries of Ceska rafinerska (in this company it operates through Unipetrol RPA - RPA stands for refineries, petro-chemistry and agro chemistry $)^{88}$ and Paramo a.s. $(100 \%$ ownership), the company is primarily engaged in the sale of fuel through BENZINA s.r.o. (100 \% ownership).

BENZINA has the largest number of petrol stations in the Czech Republic, operating 337 as of 31st December 2010. Aside from sales at its own petrol stations it manages direct bulk deliveries of fuels to other business partners and entities (see Benzina, s. r. o.).

The sole shareholder in Shell Czech Republic a.s. is the Dutch company Shell Overseas Investments B.V. Shell Czech Republic a.s. operates through a network of 186 service stations (as of 31 st December 2010) in the Czech Republic. It also refuels aircraft at the airports of Prague, Brno and Ostrava, sells automotive and industrial oils and lubricants, asphalts, chemical intermediate products for further processing, and operates as a fuel wholesaler, etc. It is also charged to act as a processor in Ceska rafinerska. All this makes the company one of the most valued in its field on the Czech market but also in the industry as whole. It entered the market in 1991 and took over the business activities of DEA Mineraloel, Lukoil and Total in the Czech Republic.

OMV Czech Republic is $100 \%$ owned by the Viennese company Vienna International Marketing-und Handels-GmbH, which is wholly owned by OMV Refining \& Marketing GmbH, a subsidiary of the Austrian group OMV A.G. Wien. It launched its independent activity in 1993 (it had been part of OMV ČSFR since 1990). The activities of OMV CR can be divided into two main areas - construction and the operation of the OMV petrol stations and trading with customers (including trade in fuels, fuel oils, lubricants and other products). OMV Czech Republic gradually took over the petrol stations of the local companies ROKAS and SETA, as well as those operated by BP, AVANTI and, most recently in 2006, ARAL. It currently operates 220 filling stations (see OMV Czech Republic).

EuroOil is $100 \%$ owned by CEPRO. It ran 192 petrol stations in total in 2009, 180 through franchising and 12 CEPRO petrol stations (see CEPRO, 2010, p. 22). The main part of the network of the company's petrol stations consists of the former network of Benzina s.p., created during privatization in the early 90 's.

\subsubsection{Use of Oil}

Oil is processed in the Czech Republic primarily for use in the transport and industrial sectors. Total oil consumption was $9.93 \mathrm{Mt}$ (including imported oil products) in 2007. $64.55 \%$ of this was consumed by transport and $27.15 \%$ in the industrial sector. Energy generation (electricity and heating) accounts for less than five per cent of total oil consumption.

88 This subsidiary also acquires resources for the petrochemicals production of the Unipetrol group including foreign crude oil purchasing for refinery products. 
Consumption was 10.33 Mt of oil (including imported oil products) in 2009. Oil product imports accounted for a total of $2.95 \mathrm{Mt}$ in 2009, an $8.5 \%$ increase over 2008. Physical imports of fuels, i.e. petrol and diesel, represented $67.4 \%$ of all imports of refined products. Exports of refined products totalled 1.23 Mt a year in 2009 and they were down by $16.1 \%(1,470,000$ metric tonnes) on 2008 . Physical exports of fuel represented approximately $45.1 \%$ of all exports of refined products (see the Czech Association of Petroleum Industry and Trade [CAPIT], 2010, p. 8).

\begin{tabular}{|l|ll|}
\hline Tab. 4.4: Oil Consumption in the Czech Republic by Sector \\
\hline Total Consumption & $\mathbf{9 . 9 2 7}$ & $\mathbf{( 1 0 0 \% )}$ \\
\hline Transformation & $\mathbf{0 . 4 5 2}$ & $\mathbf{( 4 . 5 5 \% )}$ \\
\hline Industry & $\mathbf{2 . 6 9 5}$ & $\mathbf{( 2 7 . 1 5 \% )}$ \\
\hline Transport & $\mathbf{6 . 4 0 8}$ & $\mathbf{( 6 4 . 5 5 \% )}$ \\
\hline - Petrol & 2.099 \\
\hline - Diesel & 3.691 \\
\hline - Aviation Fuels & 0.370 \\
\hline - Other & 0.248 \\
\hline Other Sectors & $\mathbf{0 . 3 7 2}$ & \\
\hline
\end{tabular}

Note: 2007 data in Mt. Data including oil products imports, which reached 2.25 Mt in 2007. Net imports of crude oil had reached 7.26 Mt, and domestic production of crude oil amounted to $0.25 \mathrm{Mt}$.

Source: International Energy Agency, 2009g, p. III.139.

\begin{tabular}{|c|c|c|}
\hline Total Refinery Intake & 8.780 & \\
\hline Refinery Losses & 0.042 & \\
\hline Total Refinery Output & 8.738 & $(100 \%)$ \\
\hline - LPG and ethane & 0.210 & $(2.40 \%)$ \\
\hline - Naphtha & 0.838 & $(9.59 \%)$ \\
\hline - Kerosene & 0.170 & $(1.95 \%)$ \\
\hline - Petrol & 1.622 & $(18.56 \%)$ \\
\hline - Diesel & 3.595 & $(41.14 \%)$ \\
\hline - Fuel Oil & 0.335 & $(3.84 \%)$ \\
\hline - Other Products & 1.968 & $(22.52 \%)$ \\
\hline
\end{tabular}

Fuels dedicated for transport and sold or distributed through the network of public and private petrol stations in the Czech Republic have a big share of country's total oil and petroleum products consumption. The remainder of the oil in the Czech Republic is used in the petrochemicals industry for the production of pharmaceutical products, detergents, dyes, explosives, fragrances, coatings, sealants, adhesives, rubbers, fertilizers, etc. 


\subsection{The Regulatory Framework of the Oil Industry}

In terms of extraction, the exploitation of oil is guided by Act No. 44/1988 Coll. on the protection and utilization of mineral resources (The Mining Act) (see "Zákon č. 44/1988 Sb.") and by the Czech Mining Authority, as in the case of coal. The trade in oil and oil products is treated in Act No. 458/2000 Coll., on business conditions and public administration in the energy sectors and on the amendment of other laws (The Energy Act).

The Czech Republic fulfils its EU and IEA ${ }^{89}$ membership obligations through the Administration of State Material Reserves (ASMR). The obligation to the IEA among other things is maintaining the reserves as of the date 31 December 2005, and maintaining a reserve at a minimum 90-days average daily consumption of oil products last year. The obligation to the EU is securing oil reserves of 90 days average of daily crude oil imports or 61 days average of daily domestic consumption of oil (it depends which figure is greater, calculated in the preceding year) to the date 31 December 2012, based on EU directives 2006/67/EC and 2009/119/EC ${ }^{90}$. The implementing legislation in the Czech Republic is Act No. 189/1999 Coll. as amended by later regulations.

The storage and protection of oil, oil products and intermediate products is realized by state-owned business entities in the Czech Republic. MERO CR is responsible for crude oil storage, while CEPRO a.s. stores oil products. Petrol, diesel, aviation kerosene, lubricating oils and heating oil are protected products (see CEPRO). CEPRO has 14 main stores, which are connected by oil products pipelines. The construction of pipelines and warehouses began during World War II (see Zabo, 2008, p. 76).

MERO CR operates the Nelahozeves Central Crude Oil Tank (CCOT), which is part of the IKL pipeline. It is used to receive oil from the Druzhba pipeline to and from the IKL pipeline; for storage and mixing of different types of oil according to customer's needs and capacities; and for oil distribution to the customer. The largest part of the CCOT's capacity is used by the State Material Reserves Administration for the storage of strategic petroleum reserves. The total storage capacity is currently 1.55 million cubic metres and consists of four tanks with a single volume of 50,000 cubic metres, six tanks with a capacity of 100,000 cubic metres and six tanks with a capacity of 125,000 cubic metres, giving a total of 16 tanks. These steel tanks are on the surface, with a steel protection pool and floating roof (see Zaplatílek, 2007, p. 70; Cieslar, 2008a).

The strategic petroleum and petroleum products reserves were stored in quantities which would last for more than 104 days according to the IEA methodology or respectively 119 days according to the EU methodology as of 31 December 2012 (that is state reserves, if business's reserves are counted in, then it is 122 days) (see MPO, 2011, p. 11).

89 The Czech Republic joined the International Energy Agency on 5 February 2001.

90 The new directive also modified the rules of the operation of storage organization, the central administrators of reserves can be exclusively established by the state and the European Commission is in charge of controlling these reserves according to this directive (see Nowak \& Hnilica, 2010, p. 7). 


\begin{tabular}{|l|l|l|l|l|l|c|c|}
\hline Tab. 4.6: Volume of Crude Oil and Oil Products Reserves Operated by AMSR as of 12/31/2010 \\
\hline Product & A & B & C & D & E & F & G \\
\hline Crude Oil & 1014.534 & - & - & - & - & - & - \\
\hline $\begin{array}{l}\text { Automotive and Avia- } \\
\text { tion Petrol }\end{array}$ & - & 284.577 & 264.977 & - & 549.554 & 5.131 & $\mathbf{1 0 7 . 1 0}$ \\
\hline Jet Fuel & - & 14.812 & 61.671 & - & 76.483 & 0.942 & $\mathbf{8 1 . 1 9}$ \\
\hline $\begin{array}{l}\text { Kerosene, Gas Oil and } \\
\text { Diesel }\end{array}$ & - & 414.843 & 665.617 & 37.64 & 1080.46 & 10.533 & $\mathbf{1 0 2 . 5 8}$ \\
\hline Heavy Heating Oil & - & 34.494 & 75.906 & - & 110.4 & 0.763 & $\mathbf{1 4 4 . 6 9}$ \\
\hline
\end{tabular}

\subsection{Demand Forecast}

For preparing the forecast of oil demand, respectively, the forecast of energy demand in the Czech Republic, it is necessary to consult the materials which affect demand in direct and the most profound manner. In the Czech Republic, these include 2004 State Energy Concept and its revisions from February 2010 and August 2010. The State Energy Concept works with a forecast by 2030. The 2010 Revision of the State Energy Concept provides forecasts by 2030 and 2050, while the revision from 2012 provides the data by 2040 .

\begin{tabular}{|c|c|c|c|c|c|c|c|c|}
\hline \multicolumn{9}{|c|}{$\begin{array}{l}\text { Tab. 4.7: The Shares of Solid, Liquid and Gas Fuels in Energy Resource Consumption According } \\
\text { to the State Energy Policy of the Czech Republic from } 2004 \text { and Its Revision from } \\
\text { February } 2010 \text { and August } 2012 \text { (in \%) }\end{array}$} \\
\hline Type of Fuel & $\begin{array}{c}\text { Level in } \\
2000\end{array}$ & $\begin{array}{c}\text { Level in } \\
2005\end{array}$ & $\begin{array}{c}\text { Level in } \\
2008\end{array}$ & $\begin{array}{l}\text { Long-Term } \\
\text { Goal (SEP } \\
\text { 2004) by } 2030\end{array}$ & $\begin{array}{l}\text { "Green" } \\
\text { Scenario } \\
\text { (SEP 2004) } \\
\text { year 2030 }\end{array}$ & $\begin{array}{l}\text { Revised SEP } \\
(2 / 2010) \\
\text { Scenario by } \\
\quad 2030\end{array}$ & $\begin{array}{l}\text { Revised SEP } \\
\text { Scenario } \\
(2 / 2010) \text { by } \\
2050\end{array}$ & $\begin{array}{c}\text { Revised } \\
\text { SEP } \\
(8 / 2012) \\
\text { Target } \\
\text { Values by } \\
\text { 2040 }\end{array}$ \\
\hline \begin{tabular}{|l|} 
Solid \\
\end{tabular} & 52.4 & 42.5 & 45.3 & $30-32$ & 30.5 & 24 & 20 & $12-17$ \\
\hline Gas & 18.9 & 21.6 & 15.7 & $20-22$ & 20.6 & 20 & 21 & $20-25$ \\
\hline Liquid & 18.6 & 15.7 & 20.9 & 11-12 & 11.9 & 20 & 19 & 14-17 \\
\hline Nuclear & 8.9 & 16.5 & 15.3 & $20-22$ & 20.9 & 25 & 25 & $30-35$ \\
\hline Renewables & 2.6 & 5.4 & 2.9 & $15-16$ & 15.7 & 11 & 15 & $17-22$ \\
\hline
\end{tabular}

Source: Státní energetická koncepce, 2004, p. 11-12, 40-49; Ministerstvo průmyslu a obchodu, 2010a, p. 77-92; Český statistický úřad, 2008; Ministerstvo průmyslu a obchodu, 2012, p. 20-21. 
Oil and solid fuels together represent the only sources whose consumption is expected to decrease, and to a very significant extent. The 2004 State Energy Concept predicted almost a half less consumption, while its February revision had a notably different version, estimating only a percentage decline of consumption on a regular bases. Even with the declining demand by one per cent, we should take into consideration the long term trend of increasing energy consumption in the Czech Republic. Nominally, we can therefore count on a steady increase in oil consumption (see the forecasts in table No. 48). The most recent revision is more ambitious as it expects a decrease by 4-7 percentage points. However, even if oil consumption stayed at the level of $14-17 \%$, the need to partially substitute this sort of fuel is impossible to avoid. Given the purposes of oil use (almost $65 \%$ for transportation services), it is assumed that the replacement of oil will take place exactly in the transportation sector. According to the State Energy Concept, natural gas is becoming a gradually more important element of the energy fuel mix of the Czech Republic, with an average share of 20-25\% of the mix. In addition to the generation of heat and electricity, it will be exploited primarily for transportation purposes, with a projected 350,000 vehicles fuelled by natural gas by 2020 and transportation gas consumption amounting to approximately $1 \mathrm{billion}^{3}$ (see Ceska plynarenska unie [ČPÚ], n.d.). Growing efficiency and the introduction of biofuels should also considerably contribute to the reducing consumption.

Tab. 4.8: Oil Consumption Prediction

\begin{tabular}{|l|c|c|c|c|c|c|c|c|c|c|c|c|}
\hline Year & $\mathbf{2 0 0 8}$ & $\mathbf{2 0 0 9}$ & $\mathbf{2 0 1 0}$ & $\mathbf{2 0 1 1}$ & $\mathbf{2 0 1 2}$ & $\mathbf{2 0 1 3}$ & $\mathbf{2 0 1 4}$ & $\mathbf{2 0 1 5}$ & $\mathbf{2 0 1 6}$ & $\mathbf{2 0 1 7}$ & $\mathbf{2 0 1 8}$ & $\mathbf{2 0 1 9}$ \\
\hline Consump. 1 & 210 & 203 & 205 & 215 & 219 & 223 & 228 & 231 & 235 & 238 & 242 & 246 \\
\hline Consump. 2 & 27.88 & 26.95 & 27.21 & 28.54 & 29.07 & 29.60 & 30.27 & 30.67 & 31.20 & 31.60 & 32.13 & 32.66 \\
\hline \% change & 100 & 96.7 & 97.6 & 102.4 & 104.3 & 106.2 & 108.6 & 110.0 & 111.9 & 113.3 & 115.2 & 117.1 \\
\hline
\end{tabular}

Note: Data Consumption 1 signifies thousands of barrels of oil per day, while Consumption 2 signifies millions of tonnes. In 2008, a daily oil consumption in the Czech Republic amounted to 210,000 barrels. A barrel of oil is 158.97 litres, consequently the consumption, therefore, came to approximately 33.4 million litres of oil per day. The consumption was calculated according to the Specific Gravity of Brent Oil $\left(835 \mathrm{~kg} \mathrm{per} \mathrm{m}^{3}\right)$. A barrel of oil in this calculation weighs $132.754393162 \mathrm{~kg}$. Source: Business Monitor International, 2010, p. 16, 72. The calculation into tonnes carried out by the author.

It is also interesting to observe the comparison of the Czech Energy Concept's forecasts and the those in its revision from February 2010. Both scenarios substantially diverge basically in terms of all sorts of fuels except natural gas. The revision compared to the original Czech Energy Concept puts surprisingly less emphasis on solid fuels, almost twice as much on liquid fuels, four times more emphasis on nuclear fuels and expresses less optimism over renewables. The 2012 revision returns to the figures from the 2004 Concept and expects greater changes only in terms of solid fuels (basic restriction) and nuclear energy (increased consumption by $10-15 \%$ ). 


\subsection{Current Issues and Proposed Projects in the Czech Oil Sector}

\subsubsection{Infrastructure Projects}

With respect to the developing perception of Czech energy security, the construction of a third pipeline which would enhance its diversification of oil sources has been considered, with two potential options in play.

The first option is to interconnect the refinery in Litvinov and German Spergau in the vicinity of Leipzig. TOTAL Raffinerie Mitteldeutschland GmbH Spergau (in the literature also called Leuna) is connected to the Druzhba pipeline. This project is pursued by MERO CR, which also initiated it and which would provide the necessary funds. The plan has been endorsed by the Czech government. Russian oil companies have also shown interest in this project. Its aim is to increase the oil security of the Czech Republic in terms of supply routes not only by closing the gap between the two branches of the Druzhba pipeline but also by providing Czech refineries with access to oil terminals on the Baltic coast: Rostock (Germany) and Gdansk (Poland). In connection with the Litvinov-Spergau pipeline, the Czech Republic could become a transit country for oil. According to current information however the owner of the German refinery, the French company TOTAL, shows no interest in this project as connecting the pipeline leading from Rostock would need further necessary investment to increase its capacity and connection to the port of Gdansk is constrained by the limited capacity in the Plock-Schwedt Druzhba pipeline section. The Litvinov-Spergau link would secure supplies of oil to the Czech Republic should transports from one of the Druzhba branches be limited and the second one be used as normal. This project however raises some concerns on the Polish side, as the East German refineries are currently supplied mainly via the northern branch of Druzhba and the Gdansk oil terminal. The owner of the Polish section of the Druzhba pipeline, the state-owned company PERN which collects the transit fees, will have a serious competitor, once the Litvinov-Spergau link has been completed.

The extent to which Czech oil security would improve is also questionable as Russian Lukoil and, until recently, also OAO Gazprom Neft have (among others) shown interest in the German refinery Spergau - these companies want the products produced there to be sold on the Polish market (see Sušanka, 2010; Žižka, 2010; “Czech Republic: Oil pipeline”, 2010; Čarek, 2009).

The second option is a pipeline connection from Klobouky u Brna to the Austrian OMV refinery Raffinerie Schwechat near Vienna. This project was also designed by MERO CR. The oil flows there from the Italian port of Trieste at present (similar to IKL). This proposal is also linked to developments in Slovakia. Within the scope of the diversification of activities in Slovakia the BSP pipeline (Bratislava Schwechat Pipeline), with a length of $62 \mathrm{~km}(50 \mathrm{~km}$ in Austria and 12 in Slovakia) and a total capacity of 2.5 to 5 million metric tonnes of oil annually, has been discussed frequently since 2003. This project was proposed by the Slovak state-owned company Transpetrol with a potential effect on the Czech Republic as well, which could diversify the oil sector in terms of pipeline routes (through Austrian Schwechat, whether it is the Druzhba or TAL pipeline), but not in terms of resources. However, the project also meets the limited capacity of the TAL pipeline. The BSP pipeline is planned as a link between the Slovnaft refinery in Bratislava and the Austrian OMV Raffinerie Schwechat near Vienna. The purpose of this project is to expand the existing Russian pipeline network to Austria, which would allow for the first time delivery of cheap Russian oil directly to Austria. For Austria it is an important diversification project, since Austria is currently supplied only by TAL (Transalpine Pipeline) and AWP (Adria-Wien Pipeline). 
The Slovaks perceive this pipeline as an essential project aiming to enhance the country's energy security. The new connection is in the first place intended to motivate Russian companies to send more oil via the southern branch of Druzhba (because there would be also other countries at its end, in addition to the Czech and Slovak Republics). Secondly, the planned capacity of the pipeline route would be able to cover a possible complete loss of oil supplies via the Druzhba pipeline (the domestic sector consumes about 2.7 Mt of oil annually) in the event of loss of supplies from the East, however, only if there would be spare capacity in the TAL-AWP section. Also the Schwechat refinery consumption would have to decrease to compensate for oil intended for Slovakia in this case.

The owner of the Bratislava refinery, Slovnaft, owned by the Hungarian company MOL, is promoting an alternative project. MOL, which is a rival of the Austrian owner of the Schwechat refinery (OMV), is championing the idea of modernizing the Adria oil pipeline which could carry oil from the coast of Croatia to the Czech Republic and Slovakia. This plan is not particularly interesting for Slovakia because of the high transport tariff ( $24 € /$ tonne/whole line) and limited capacity. The Adria pipeline is currently used only occasionally, for transport in the direction and in the section of Sahy-Szazhalombatta.

The chances of implementation of the BSP project have increased after the Robert Fico-led government came to power in Slovakia. The venture involves Austria's OMV and Slovak Transpetrol (The sole owner of Transpetrol is Slovakia). The Austrian Federal Minister for Economic Affairs Reinhold Mitterlehner and his Slovak counterpart Lubomir Jahnatek signed a Memorandum of Understanding on 19th October 2009 to enhance cooperation between Austria and Slovakia in the area of trade in oil and natural gas, based on which pipeline construction should start in 2012. A joint venture Bratislava-Schwechat Pipeline $\mathrm{GmbH}$ will be established to realize this project; it will consist of Transpetrol Bratislava (74 \%) and OMV Refining \& Marketing GmbH, Vienna (26 \%) (see "Memorandum of Understanding”, 2009).

There are no obstacles on the Austrian side of the project. One of the key issues on the Slovak side is the proposed pipeline route, as the one previously proposed via Bratislava Zitny ostrov is very problematic in terms of environmental hazards (risk of contamination of an aquifer) (see "Jahnátek: Spojit", 2009, "Na vytyčení novej trasy," 2008; "pipeline Bratislava - Schwechat", 2009, "OMV prosazuje," 2009). The campaign against the pipeline by the Slovak public has been relatively successful, and that is why nine other routes are still under consideration alongside the most economic route via Bratislava Zitny ostrov. Therefore, the overall length of the pipeline may be 81 to $152 \mathrm{~km}$ according to the selected route and cost $€ 70$ to $€ 112$ million. 


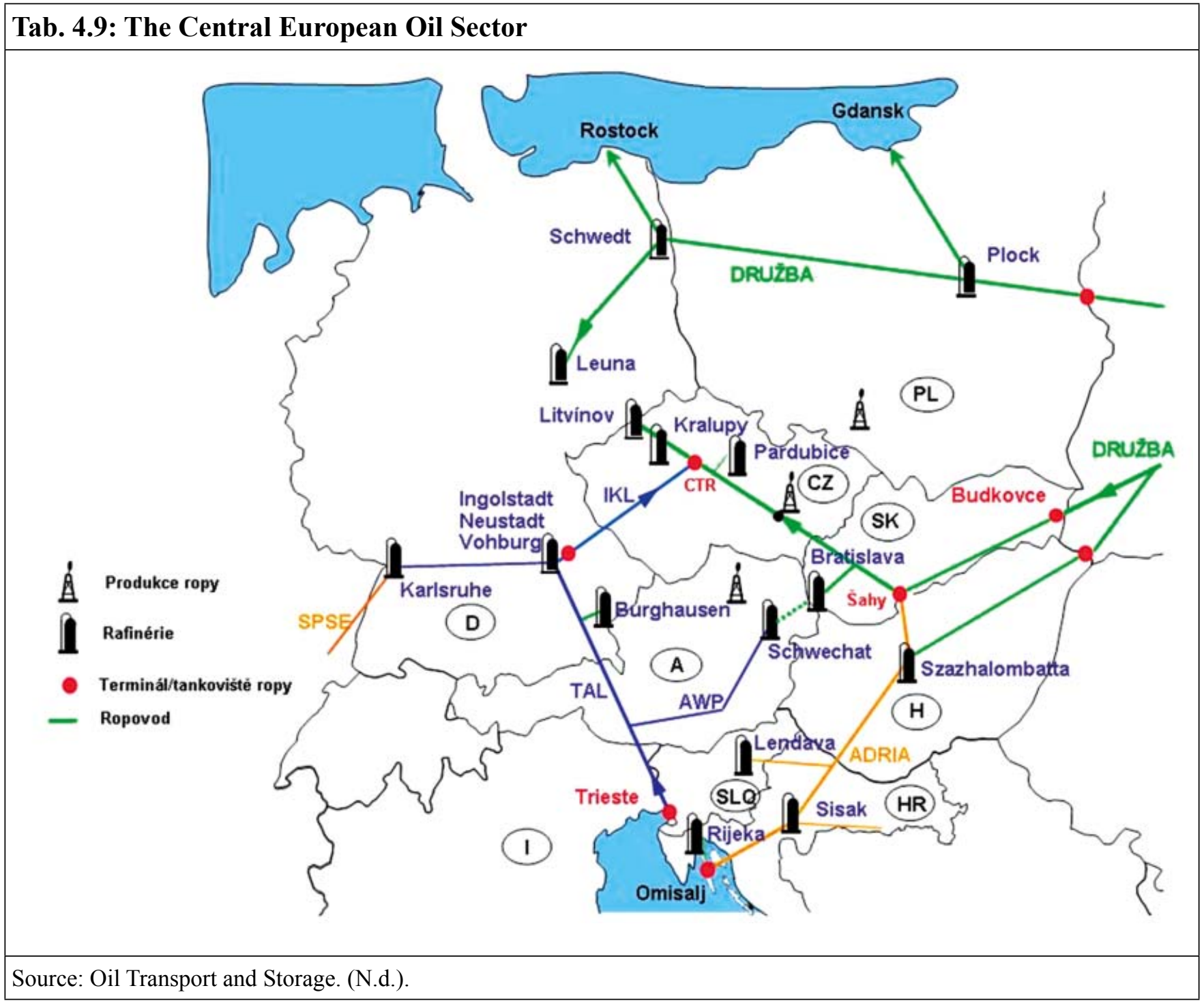

In addition to the mentioned projects Czech entities are further involved in existing pipelines. One of the projects proposed by MERO CR is the reverse operation of the IKL pipeline with the aim of delivering Russian oil through the Druzhba and IKL pipelines to German refineries, and by doing that to increase the interest of the Russian Federation in exports via the southern branch of the Druzhba pipeline, and to increase its own profits from the transport of oil. However, the project faces a difficult swing operation. In the case of the possible supply of crude oil from Russia to Germany, a volume of approximately 110,000 metric tonnes (that is the pipeline capacity between stations in Vohburg and Kralupy nad Vltavou) would need to be pushed from the pipeline. Since the pipeline cannot be empty, oil would have to be pushed by oil from the Druzhba pipeline. This is, nonetheless, technically implausible and even if it were possible, pushing oil back to Vohburg would occupy more than $50 \%$ of MERO's storage capacity, which is by itself problematic. Technological issues for refineries should be carefully considered as they are set to process a certain kind of oil blend and to process a different one presents extra costs from altering technology or a significant decrease in product yield.

The Czech state is trying to secure a secondary oil supply in the event of disruption of the Druzhba pipeline. The IKL pipeline is a rational choice; it follows the Italian-Austrian-German TAL pipeline (Transalpine Ölleitung). Utilization of the IKL pipeline reaches $20-40 \%$, so it would seem that there is 
enough space to increase supply. However, the pipeline is linked to the TAL pipeline, which is used to almost $100 \%$ capacity and the possibility of increasing the supply to the Czech Republic is thus minimal. One solution is to have ownership in the TAL pipeline, which would automatically secure a permanent capacity share for the country. TAL is owned by a group of nine companies: OMV AG (25\%), Royal Dutch Shell p.l.c. (24\%), Petroplus Holdings AG (10\%), Exxon Mobil Corporation (6\%), Ruhr Oel GmbH (11\%), Eni SpA (10\%), BP p.l.c. (9\%), ConocoPhillips Company (3\%) and Total (2\%). The Czech Republic is trying to negotiate the purchase of a two percent stake in the pipeline through MERO CR (see Hovet, 2008; Stopp, Voltz, \& Lother, 2005, p. 24; The Transalpine Pipeline, “Oil Transit Company," 2010; Graham, 2008; Jones, 2010). This was achieved on September 25, 2012, when the companies MERO CR, a. s. and Shell Deutschland Oil GmbH signed the Stock Purchase Agreement on whose bases MERO Group acquired a $5 \%$ share in the companies owning and operating the TAL pipeline.

The Druzhba pipeline can be used only at up to 12-months nomination of capacity in advance with a flexibility of $+/-10 \%$. The IKL pipeline can be used only with 18-months nomination of capacity in advance. In addition, shareholders in the pipeline are served first. Delivery takes 6 to 8 weeks from loading an oil tanker in the Persian Gulf through unloading in Trieste to delivery to Kralupy nad Vltavou. Pipeline capacity is $42 \mathrm{Mt}$ per year, but there is potential to increase it to more than 50, by renewing the operation of the pumping stations on the route of the pipeline that were taken out of service. Two out of the six stations are currently operating, and the cost of renewing each of the four remaining stations would be of the order of hundreds of thousands of euro.

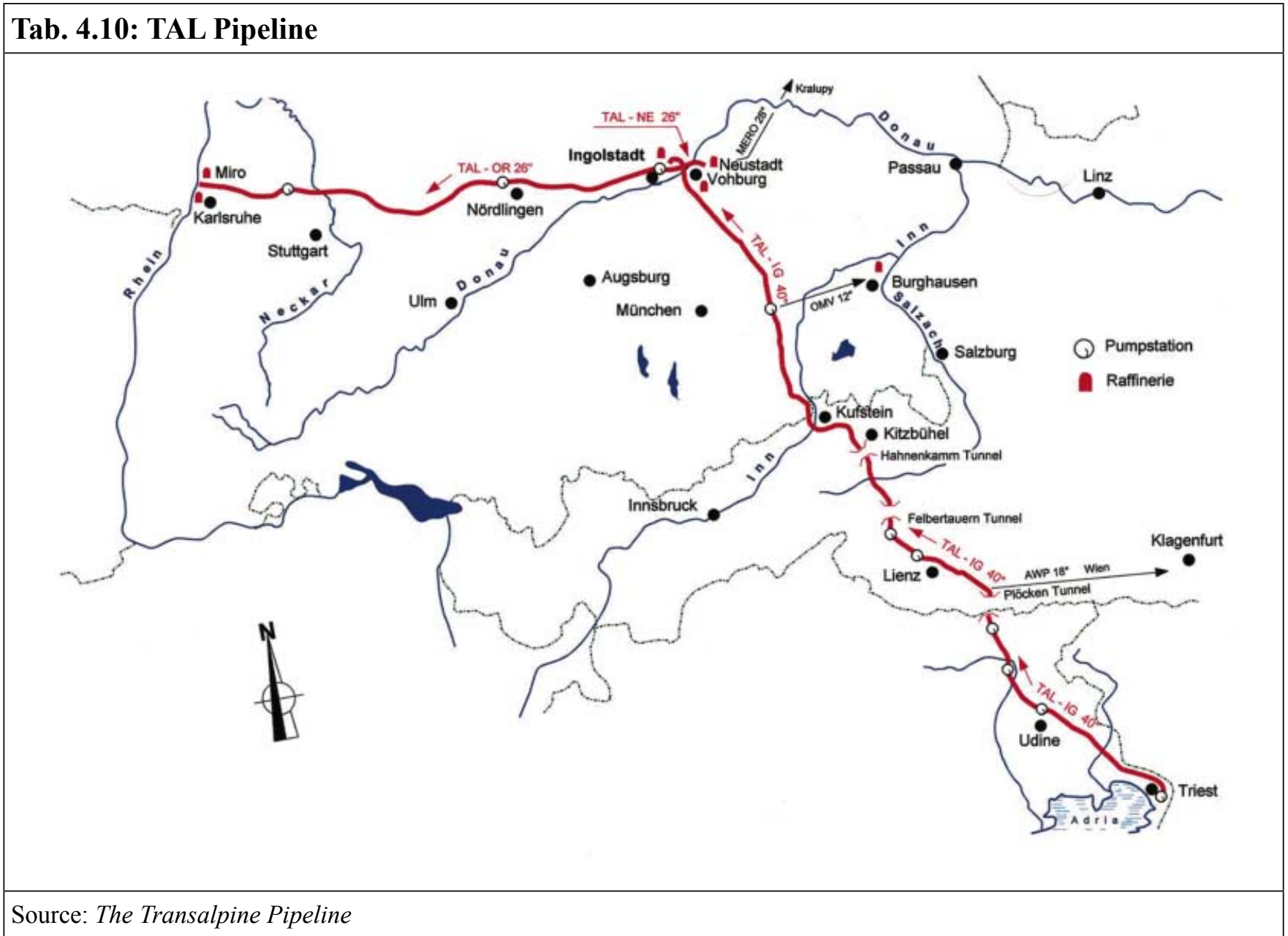


The current project is a proposal to increase the emergency petroleum and petroleum products reserves. The document entitled "Analysis of the possible involvement of private business in the storage of emergency petroleum and petroleum products reserves in order to implement the required increase in petroleum and petroleum products reserves to a level equal to 120 days of consumption" based on the requirement of Government Resolution of 30th January 2008, which was submitted and approved by the National Security Council on 27th April 2009 and in which it was proposed to increase the petroleum and petroleum products reserves to 120 days of consumption. Therefore the petroleum and selected petroleum products reserves are to be maintained pursuant to Act No. 189/1999 Coll. on emergency petroleum reserves, as amended, at a level of at least 90 days of net imports. These reserves represent the mandatory reserves and are primarily intended to address an oil emergency, fulfilment of international obligations arising from membership in the IEA and the EU, and to address other emergency situations. Moreover, an additional type of reserve will be set up (i.e. strategic reserves), thereby increasing the total volume of reserves up to a level of 120 days of net imports (see Nowak \& Hnilica, 2010, p. 9; Administration of State Material Reserves, 2009, MIT, 2010). The reserves will cover both emergencies and are also to be used by businesses to cover their needs in the form of a loan from ASMR, without jeopardizing the mandatory level of reserves and the need to notify the EU about its decrease. The idea however has been criticized by players in the oil market who may be exposed to additional costs.

In July 2012, the Government passed a bill introducing the changes of Act No. 189/1999 Coll. on emergency oil reserves, on oil emergency management and on amendment of some associated Acts (The Act on Emergency Oil), as amended. The Act no longer operates with the term strategic reserve, but it adds to the emergency reserves at the level of minimum 90 days of net imports specific reserves which can include emergency reserves. The Czech Administration of State Material Reserves (SSHR) can form specific reserves from seventeen products in an amount corresponding to at least 30 days of average daily domestic consumption in the reference year for at least a one year period.

Specific reserves would accordingly increase the emergency ones, but they would also serve the business sector for possible coverage of its needs in the form of a SSHR loan without endangering the quota of obligatory reserves and the requirement to give the EU notice of their reduction. Specific reserves also enable disposal of ad hoc reserves relative to market development without necessarily increasing all products' blanket reserves as indicated by the EU and IEA legal acts.

\subsubsection{The Druzhba Pipeline}

In June 2007, the Polish newspaper Dziennik was the first to release, since then, frequently repeated information that Russia was considering shutting down the Druzhba pipeline (see Roškanin, 2007b, p. 8). It is very likely that Russia will gradually start giving the advantage to the export of processed and as much as possible finished materials at the expense of unprocessed materials (see Kavina, 2009, p. 322). Russia is preparing a project which would bypass the transit countries (mainly Belorus) by branching off the Druzhba pipeline in Jaroslavl and with a pipeline leading to Primorsk Port with tankers prepared for transportation of oil and oil products to further destinations. The curtailment of supplies westwards also represents a permanently growing risk as a result of growing oil demand coming from Eastern customers. Russia is building the ESPO pipeline leading to the East-Siberian Kozmino Port (Козьмино) with tankers prepared to proceed with further oil exports.

The Czech Republic has experienced several disruptions of oil supplies via the Druzhba pipeline. It happened due to disputes between Russia and Ukraine on the transportation fee for oil in 1990, 1991, 1994, 1995, 1996 and because of difficulties in license issuing and internal problems in the Soviet Union (in 
1990), or due to technical issues. The oil supply through Belarus was cut off in 2007 because of disputes over the rate of duty between Russia and Belarus. Oil supplies via the Druzhba pipeline were curtailed on Czech territory by $50 \%$ in the summer of 2008 . The Russians explained the situation as an issue in a complex chain of interconnected suppliers. However, the supplies were curtailed just the day after (9th July 2008) the Czech Republic signed the agreement on establishing a missile defence radar base in Brdy with the U.S. The situation was easily resolved however by increasing deliveries through the TAL/IKL pipeline system (aside from the use of state petroleum reserves, additional supplies were secured from Iran, Norway and Saudi Arabia, all in one day). The July curtailment had much more unpleasant consequences for Russia than for the Czech Republic, since Germany and Great Britain questioned Moscow about the curtailment, and Russia's reputation as a reliable supplier was damaged. The risk of oil supply disruption reappeared when Russia got into a dispute with Ukraine on transit fees once again in December 2009, but the situation was resolved by agreement between Moscow and Kiev on terms of a new contract and no disruption occurred (see Nowak \& Hnilica, 2010; "Rusko hrozí Evropě”, 2009; Roškanin, 2008a, p. 9).

The most recent problems in the oil supply via Druzhba took place in April 2012. During the first ten days of the month oil supplies from the East to the Czech Republic fell by $31 \%$ in comparison with the amount logged by Russia. Transneft, which coordinates exports of Russian oil, announced on 9th April that Russian companies did not deliver any orders for the transfer of oil to the Czech Republic. However, the following day Transneft added that in the second quarter the supplies would be delivered according to the contract. The most likely reason for this decrease in oil supplies is the reorientation of Rosneft and Lukoil towards transporting oil through the BTS-2 pipeline system. This system was opened at the end of March 2012 and is expected to export Russian oil while bypassing transit countries. However, it is also likely that Russian companies used this opportunity to test how owners of Czech refineries (Unipetrol, Eni and Shell) would react to decreased oil supplies in the context of the newly-opened BTS-2 and how flexible they can be in accepting an increase in the oil price. It cannot be ruled out that this was also a signal of possible renegotiation of supply conditions for other purchasers who receive supplies via the southern branch of the Druzhba pipeline.

\begin{tabular}{|c|c|}
\hline \multicolumn{2}{|c|}{ Tab. 4.11: Oil Curtailment to the Czech Republic } \\
\hline Year & Reason for Curtailment \\
\hline 1990 & Domestic problems in the Soviet Union. \\
\hline 1991 & Curtailment solved by additional supplies via IKL pipeline. \\
\hline 1994 & Curtailment of oil supply due to a stop in license issuing. \\
\hline 1995 & Dispute between Russia and Ukraine over the rate of oil transit fee. \\
\hline 1996 & Dispute between Russia and Ukraine over the rate of oil transit fee. \\
\hline 2007 & $\begin{array}{l}\text { Dispute between Belarus and Russia over the rate of oil transit fee. Russia imposed export duty on oil exports to } \\
\text { Belarus, which imposed countermeasures resulting in another curtailment of supply. }\end{array}$ \\
\hline 2008 & $\begin{array}{l}\text { Russia decreased oil supply to the Czech Republic to approximately } 50 \% \text { of volume. The reason for this might } \\
\text { have been the signing of an agreement between the Czech Republic and the U.S. on establishing a missile defence } \\
\text { radar base in Brdy. Curtailment solved by additional supplies via IKL pipeline. }\end{array}$ \\
\hline 2009 & $\begin{array}{l}\text { The blackout in western Ukraine caused the curtailment of Russian oil to Europe. The risk of curtailment due to } \\
\text { a dispute between Russia and Ukraine over the rate of oil transit fee. }\end{array}$ \\
\hline
\end{tabular}


The state does not have the contracts to supply oil to the Czech Republic under control and does not have almost any way to regulate supply. Oil contracts are fully under the control of private enterprises in the Czech Republic. "Oil is not contractually guaranteed in the long term. In this situation, we are more dependent on the global oil situation to which we must respond by monitoring the overall situation, good diplomatic relations with several producers, extension of strategic reserves and by a savings programme and by the next generations of Biofuels" (see UVCR \& NEK, 2008, p. 65). Due to its high utilization not even the IKL pipeline is a completely reliable insurance policy (see above).

In the context of oil supplies curtailment the Czech Republic negotiated two important agreements in the summer of 2008. The first is a memorandum between the carriers MERO CR and OAO AK Transněft' (OAO АК Транснефть), which should secure a steady supply of resources to the Czech Republic. The Russians will inform the Czech side of their future intentions with the Druzhba pipeline and provide early warning of disruption on the basis of this memorandum. The Czech Republic has a similar contract with the other operators of Druzhba already, with Ukrainian BAT UkrTransNafta (BAT УкрТрансНафта) Belarusian RUP Gomeltransneft Druzhba (РУП Гомельтранснефть Дружба) and Slovak Transpetrol (see Roškanin, 2009, p. 6; MERO CR, 2010). The second contract, signed on 23rd November 2010, is a contract between MERO Germany AG, a subsidiary of MERO CR and the German Deutsche Transalpine Oelleitung $\mathrm{GmbH}^{91}$, which is one of three companies operating the TAL pipeline. This contract applies to the extension of the existing contract allowing the transport of more oil via the Western European TAL pipeline for Czech refineries at a time when there are problems with the Druzhba pipeline. MERO CR can use free shipping capacity of the TAL pipeline system beyond the usual long-term liabilities in this case, without any exorbitant extra cost. The new amendment to the contract is valid until 2015 (see "Výpadky ropovodu Družba,” 2010; Jones, 2010).

The topic of switching the direction of oil flow in both pipelines has been discussed in the oil sector in the past. The Czech government stopped work on the preparation of the transit of oil via the Druzhba pipeline through Czech territory to Germany via the IKL pipeline in 2006 as it would undermine the route diversification achieved during the 1990s (see Roškanin, 2006, p. 6). Slovakia negotiated with the Czech Republic about the possibility of switching the oil flow of the Druzhba pipeline. Switching the direction of pipeline oil flow is technically possible at fairly limited costs - e.g. several million euro, which would have to be provided by the Slovak side (see Roškanin, 2008d, p. 7). This project nevertheless progressed no further.

The matter has several possible solutions, which Tomas Huner from the Ministry of Trade and Industry briefly summarized: "There are a number of solutions, from a technology change solution in Litvinov and Pardubice refineries that would allow them to process light oil, through transport of Russian or similar crude oil via the IKL pipeline, to the transport of Russian oil via another pipeline in Ukraine up to that part of the Druzhba pipeline that goes through Slovakia to the Czech Republic" (see Roškanin, 2007d, p. 9). Czech refineries are now specialized, the oil refinery in Litvinov (Ceska rafinerska) processes the Russian REB oil blend imported via the Druzhba pipeline, while the refinery in Kralupy nad Vltavou (Ceska rafinerska) focuses on the processing of sweet domestic and imported crude oil supplied via the IKL pipeline, and finally the refinery in Kolin (Paramo) uses resources from the Litvinov refinery.

Overall technological change is of course possible, but expensive and time consuming. The transfer of Druzhba oil pipeline capacity to the IKL pipeline is problematic due to its full capacity utilization (see

91 In addition to Deutsche Transalpine Oelleitung GmbH the pipeline is operated by the Austrian Transalpine Ölleitung in Österreich Ges.mbH and the Italian Societá Italiana per 1'Oleodotto Transalpine SpA (see The Transalpine Pipeline Available on http://www.tal-oil.com/). 
above). The option of oil transport via the junction of Druzhba in Ukraine, i.e. via the Odessa-Brody pipeline (also-called the Sarmatia pipeline) has been more discussed than acted on for the past ten years. The pipeline was originally supposed to be extended to the Polish city of Plock, but only the part from the city of Odessa to Brody has been constructed. The pipeline has also been used for completely different purposes than it was built for. Until 2010 it was used for transporting Russian oil from the Druzhba pipeline via Brody and via the Sarmatic pipeline to Odessa, where it was then shipped via tankers at the oil terminal in Odessa (Одеса) and Pivděnnyј (Південний). According to an agreement signed in the beginning of 2011, the Odessa-Brody pipeline was also used to transport Azeri crude oil (Azeri Light) to the Belarusian refinery in Mozyr. The amount supplied last year reached $1 \mathrm{Mt}$. However, since the beginning of 2012 the deal has not been continued. The infrastructure projects described above are also responses to reports about the possibility of curtailing or cutting off the Druzhba pipeline.

Efforts to transfer the export of oil to oil tankers and the transition from the export of crude oil to the export of oil products are real aspects of Russia's energy strategy. A different question is, whether, and to what extent this declared strategy can pressure importers so that they themselves use their resources more intensively to put political pressure on transit countries.

\subsection{Summary}

There is strong know-how and experience present in the Czech oil sector, based on the oil industry which on our territory has more than a hundred years of history. The country's oil market is dynamic, among other things it, for example, records constant growth in petrol stations. On the one hand, it represents an indicator of the market's vitality and raises refining and distribution demand, however, in its final result the volume of imports from abroad is boosted as well, especially from Russia ${ }^{92}$ and the country's dependence is mounting. In the event of the supply crisis in $2008^{93}$, it became evident that the Czech Republic was far from dependant on the Druzhba pipeline, as usually thought, and that it managed to solve the situation completely without affecting the trade sector. Domestic sources are, however, insignificant and import dependency for the major volume of oil, along with all issues which such oil involves (for example, transit fees ${ }^{94}$, curtailment of supply, etc.) will remain a long-term characteristic of the Czech oil sector. According to the estimations, the Czech Republic expects increasing oil consumption.

The Russian plans for transportation in the future involve the transport of oil materials processed

92 In addition to Deutsche Transalpine Oelleitung GmbH the pipeline is operated by the Austrian Transalpine Ölleitung in Österreich Ges.mbH and the Italian Societá Italiana per 1'Oleodotto Transalpine SpA (see The Transalpine Pipeline Available on http://www.tal-oil.com/).

93 The Czech Republic is specific in terms of its relationship to the Russian Federation. It is naturally given by 40 years of Soviet domination as well as the development of politics following 1989. Maximum effort was invested in breaking away from and dissociating from Russia and connecting with the West as quickly and as profoundly as possible. To the right of the political spectrum, similar affiliations are still maintained. At the international level, the typical Czech approach to Russia has been and still is represented primarily by the figure of Alexandr Vondra (former Foreign Minister of the Czech Republic, former Deputy Prime Minister for European Affairs) and Vaclav Bartuska (the Czech Republic's Special Envoy for Energy Security, appointed in 2006 by Alexandr Vondra). Such Czech political thinking to a great extent limits even "casual" trade relations of both countries.

94 Here it is necessary to point out that the strategic reserves of oil and oil products held by MERO CR and CEPRO go far beyond the level directed by the International Energy Agency and EU. The Czech Republic met the EU requirements even before the set date - December 12, 2012. Strategic storage reservoirs with oil and oil products in terms of oil supply represent an important element of the Czech Republic's energy security. 
and finalized to the greatest extent possible, while the reality of the Russian refinery sector qualifies these plans as rather empty proclamations. Unlike the restriction of supplies as the result of a Russian deliberate decision, it seems that a greater threat lies in the failure of trade negotiations either between oil owner and transit countries or between the owner of the Czech refinery capacities and the oil supplier. PKN Orlen SA negotiates with the Russian Federation about regular oil supplies based on a joint contract for all of its refinery facilities (i.e. in addition to the Czech facilities, for the facilities PKN Orlen SA in Polish Płock, Trzebinia and Jedlicze and Lithuanian Możejki). Should PKN Orlen SA not reach agreement with the Russian Federation, this could easily cause trouble with oil supplies to the Czech Republic. ${ }^{95}$

As previously indicated, the Czech refinery companies are configured for a particular sort of oil. This does not mean that, for example, the Russian type of oil cannot be imported also from somewhere in the West. Generally, refinery companies manage to process any kind of oil, however, the more it differs from the character of oil these refineries were originally configured for, the lesser the utilization is, while the unit costs are raising at the same time. A refinery perceives the processing of significantly different oil as economically entirely pointless. The Czech refineries are, moreover, not dependant on Russian oil but on medium heavy oil, whose producer, among other producers, is specifically Russia. While substituting for potential restricted supplies through the Druzhba pipeline, refineries would not look for Russian oil in western pipelines, but they would ask for oil which is most like it, respectively, a heavy, sulphurous one. Oil from Iran, for example, proves to be adequate. In that regard, it should be emphasized that the oil diversification of a country is sufficient, with an exception if the restricted capacity of the TAL pipeline occurs. For that reason, we should appreciate the successful purchase of an ownership share of the TAL pipeline and potentially support the further diversification projects which diversify only the routes of oil supplies and not the regions rich in oil.

Due to natural conditions, the Czech Republic is quite isolated from other markets. The mountain massifs at the borders and the lack of a pipeline connection (except for Slovakia) limit the import of products from abroad or raise its price. Consequently, the Czech Republic has slightly higher prices on the domestic trade market exactly due to the limited import alternatives sentenced to cargo or train routes, which make imports more expensive. According to unofficial information, the prices of products are higher by 10 USD per barrel than when obtaining them beyond the borders, which has a positive impact on Czech refineries' competitiveness. Connection to pipelines from abroad (from Germany, for example) would considerably simplify the entry of foreign products to the Czech market, which would lead to a positive effect finding its expression in the general reduction of fuel and other product prices by, as above-mentioned, 10 USD. On the other hand, this development could potentially lead to the refineries' collapse and the decay of the Czech refinery sector.

The Czech refineries make use of this situation and try to limit activities leading to the simplified cross-border transport of products. The only real competitor to the Czech refineries is the Slovak company Slovnaft, as it is connected to the CEPRO product pipeline network via the pipeline from Bratislava. From the entire PHM import to the Czech Republic, approximately two thirds of that volume is imported by the Slovak pipeline network, which is in the ownership of Slovnaft.

95 In the case of the Druzhba pipeline, the supplier pays the transit fees already at the transfer point Budkovce at the SlovakUkrainian border. From there, first the consumers of the Slovak transit company Transpetrol and then of the Czech MERO CR pay the transit. In the case of the IKL pipeline, the supplier pays the transit fees for reaching the Augusta Port in Sicily (the orientation point for the Mediterranean Sea). The consumer then pays for the transit from Augusta to Trieste for transportation through the TAL and IKL pipelines. 



\section{Chapter 5: The Natural Gas Sector 96}

Tomáš Vlček

\subsection{Introduction}

The Czech Republic reached the peak development of its gas industry in the 1960s. In addition to the launch of the gasification process (the shift from coal gas to natural gas, which was completed with gasification of the entire Republic in 1996), centralization took place as well as the arrangement of external supplies of natural gas from aboard. In 1967, the Brotherhood pipeline was launched (in 1969, the connection from Slovakia to Austria's Baumgarten and der March followed), which in 1970 was extended to Germany under the name Transit pipeline (see Blažek, 2009, p. 134). The Transit pipeline started running in 1972. Given its geographical position, the Czech Republic since then has represented an important transit country for Russian gas directed westwards.

In the 1990s, the Transit pipeline was opened up to privatization. It did not take place until 2002, when the pipeline was purchased by the German company RWE. ${ }^{97}$ In 1996, the Government under Vaclav Klaus announced the need to diversify natural gas supplies and so remove absolute dependence on the Russian Federation. The importance of that decision also lies in the fact that the then Minister of Industry and Trade, Vladimir Dlouhy, announced the triumph of the Norwegian company Statoil in the presence of the Norwegian King Harald V (see Strašíková, 2009). On May 1, 1997, when natural gas flowed in from Norway for the first time ${ }^{98}$, currently covering 34.6 \% (2009) of Czech demand, the Czech Republic, therefore, substantially enhanced its security of supply. The Czech Republic has in that manner become the first and, so far, the only Central European country which has diversified its supplies of natural gas. In 2009, a total of $8.6698 \mathrm{bcm} / \mathrm{y}$ (see MPO, 2010g, p. 4). In 2011, the figures were $9.3213 \mathrm{bcm} / \mathrm{y}$, while that amount was additionally supplemented by domestic supplies, which included surface degasification and the extraction of natural gas in the amount of $135.2 \mathrm{bcm} / \mathrm{y}$ (see Energetický regulační úřad / Operátor trhu s elektřinou, 2012, p. 3).

96 Here we should add that the Czech market approximately presents a mere $1.5 \%$ percent of Russia's oil export volume. Motivation for maintaining these exports can be of two kinds: political, related to the EU and the market, since the Czech Republic pays the market price of oil and its payments are punctual - in other words it represents certain income.

97 The chapter in some of its parts makes reference to the publication of the research project The Future of Natural Gas Security in the V4 Countries: A Scenario Analysis and the EU Dimension (see Černoch, Dančák, Kovačovská, Ocelík, Osička, \& Vlček, 2011).

98 No less interesting is that OAO Gazprom has several times showed interest in the Transit pipeline. Even though their offers were equal to the competition's and they even committed to engage in the further development of the gas network (and the Benzina network of petrol stations), the offer was each time rejected for political reasons (for more details see Blažek, 2009, p. 152-153). 


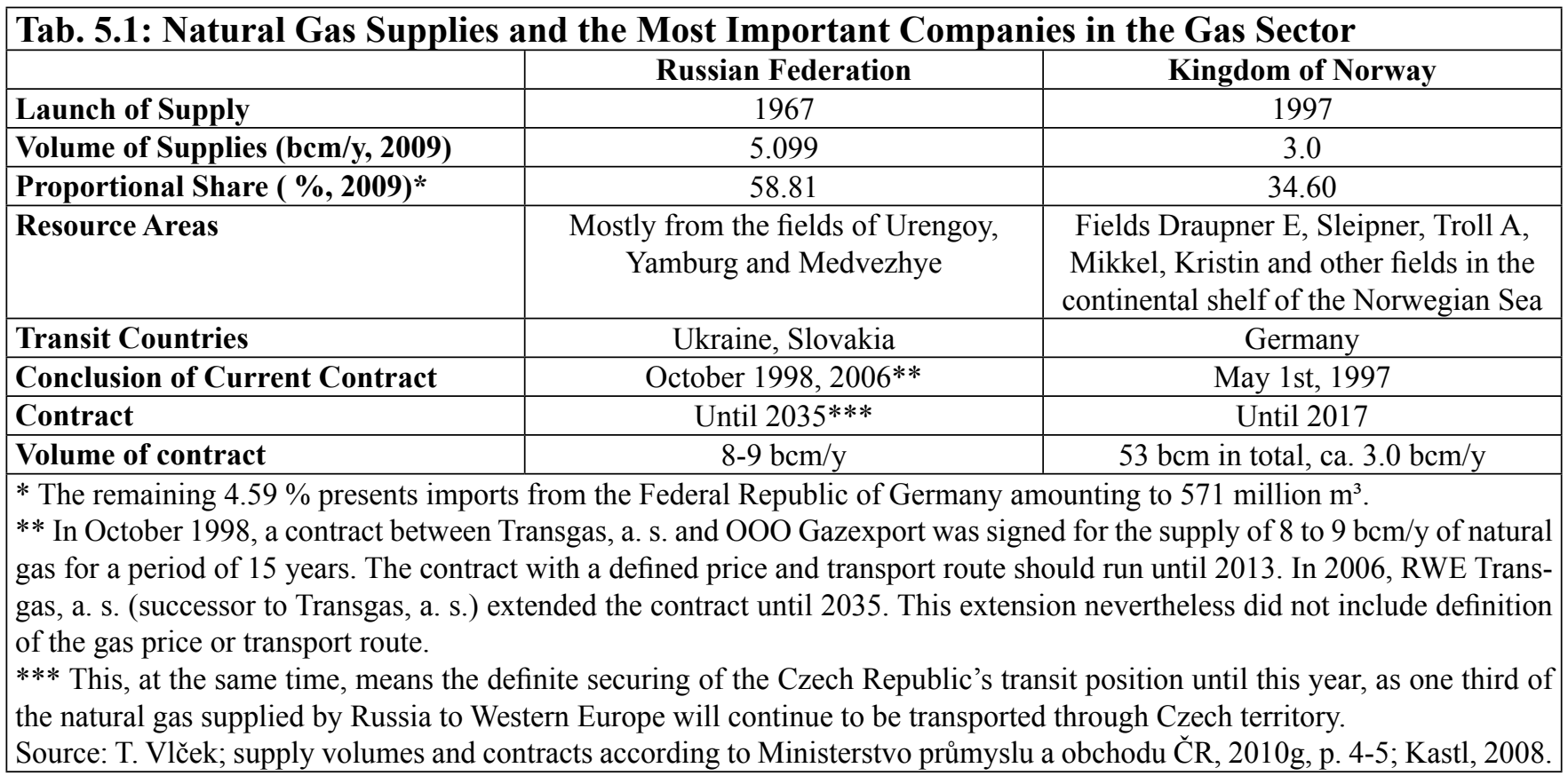

\subsection{Deposits, Mine Production, Companies and Traders}

In terms of categorization, the Czech gasworks system can be divided into two levels. The first level is the Czech system of gas pipeline operators who participate in the gas market and is made up of three different kinds of player: those involved in gas transit, gas distribution and gas sales. (1) The current holder of an exclusive license for gas transit is NET4GAS, s. r. o., which operates more than $3600 \mathrm{~km}$ of gas pipeline. (2) Eight operators of regional distribution networks, who own their own facilities, are directly connected to the transit network ${ }^{99}$. (3) More than 80 operators of local distribution networks, who own their own facilities, are not connected to the transit network.

The second level of categorization distinguishes the role of the gasworks' single parts on the Czech gas market. It involves mining companies, then holders of purchase contracts, transportation, transit and distribution of natural gas and, finally, natural gas traders.

\subsubsection{Deposits and the Production of Oil in the Czech Republic}

Natural gas is a mixture of gaseous and liquid alkanes ranging from methane to butane (respectively $\mathrm{CH}_{4}-\mathrm{C}_{4} \mathrm{H}_{10}$ ), which makes natural gas, unlike oil, basically the same regardless of where in the world it comes from, differentiated only in terms of the content of other hydrocarbons, dust, water and sulphurous materials, that is contents which are cleaned out before the extracted natural gas is sent to the long distance transport. The Czech natural gas deposits are very small, located in Southern and Northern Moravia. The natural gas deposits are almost exclusively tied to basins with oil.

99 Pražská plynárenská Distribuce, a. s., STP Net, s.r.o., E.ON Distribuce, a.s., SČP Net, s.r.o., ZČP Net, s.r.o., VČP Net, s.r.o., JMP Net, s.r.o. and SMP Net, s.r.o. Aside from E.ON Distribuce, a.s. and Pražská plynárenská Distribuce, a. s. all the remaining operators of regional distribution networks and transport companies belong to the gas group RWE Energy AG. 


\begin{tabular}{|c|c|c|c|c|c|c|c|}
\hline & 2005 & 2006 & 2007 & 2008 & 2009 & 2010 & 2011 \\
\hline Deposits - total number & 84 & 84 & 85 & 88 & 92 & 94 & 83 \\
\hline - exploited & 38 & 40 & 39 & 41 & 49 & 52 & 48 \\
\hline Total mineral reserves & 46542 & 46811 & 45989 & 46044 & 46140 & 28924 & 30172 \\
\hline - economic explored reserves & 3848 & 4109 & 4139 & 4265 & 4339 & 6123 & 7374 \\
\hline - economic prospected reserves & 40643 & 40593 & 39765 & 39807 & 39895 & 2281 & 2335 \\
\hline - potentially economic reserves & 2051 & 2109 & 2085 & 1973 & 1906 & 20520 & 20463 \\
\hline - exploitable (recoverables) res. & 27982 & 28160 & 27819 & 27812 & 27846 & 4767 & 4660 \\
\hline Production & 356 & 148 & 148 & 168 & 180 & 201 & 187 \\
\hline \multicolumn{8}{|c|}{$\begin{array}{l}\text { Note: reserves numbers in bcm. } \\
\text { Source: Ministerstvo životního prostředí / Česká geologická služba - Geofond, 2010, p. 185; Ministerstvo životního prostředí } \\
\text { / Česká geologická služba - Geofond, 2012, p. } 102 \text {. }\end{array}$} \\
\hline
\end{tabular}

A total of six companies is engaged in gas extraction, namely Moravske naftove doly, a. s., Hodonin; MND Gas Storage, a. s., Hodonin; MND Production, a. s., Hodonin; Green Gas DPG, a. s., Paskov; UNIGEO, a. s., Ostrava-Hrabova and Ceska naftarska spol. s. r. o., Hodonin. The total supply provided by Moravske naftove doly, a. s., and its daughter companies in 2009 was 105.1 million m$^{3}$ (see MPO, 2010g, p. 4). Green Gas DPB, a. s., Paskov was another important supplier with 8.2 million $\mathrm{m}^{3}$ in 2009 (see MPO, $2010 \mathrm{~g}$, p. 4). Green Gas DPB, a. s. is active in surface degasification, which is the mining of absorbed natural gas (sometimes known as coal mine gas). Absorbed natural gas is a less traditional source tied to black coal, whose genesis is not precisely known. Either it is released from coal or it, like other caustobioliths, emerges as a result of sufficient pressure and temperature in sediments over a longer time. Green Gas DPB, a. s., extracts this gas in the depths of the closed black coal mines of OKD, a. s. Degasification involves air being released into the mine wells and the ensuing drainage of the pumped gas. Adsorbed gas presents $88 \%$ of total extracted supplies of natural gas in the Czech Republic.

Other mining companies have a minimal share in total extraction volume (187 million $\mathrm{m}^{3}$ in 2011 ) and they sell the extracted gas abroad.

\subsubsection{Holders of Purchase Contracts}

The largest holder of purchase contracts in the Czech Republic is RWE Transgas a. s., a gas and power trader. RWE Transgas is responsible for two contracts for the purchase of natural gas from Russia and Norway and, at the same time, it organizes the purchase of natural gas for RWE Group customers in the Czech Republic.

Trade in gas is specific in that it proceeds on the basis of long term contracts, in spite of developing EU liberalisation activities. The long term contracts provide consumers with stability of supplies, while as far as suppliers are concerned, they represent the grounds and capital necessary for extraction, transportation, research and other activities. Generally, the price of natural gas then to a certain measure depends on significant costs of extraction and transportation themselves, while it is largely dependent on the price of oil, oil products and electricity. This method of pricing was introduced in the 1980s and fully implemented in the 1990s. Until that period the price of natural gas had been fixed on a production costs 
basis. Resulting from the very low price of natural gas (compared to oil), increasing demand and its use as well as in relation to the pressure which the producing countries exerted, the current form of pricing has been implemented since 1980, when natural gas pricing based on the price of oil and oil products was proposed at the session of OPEC in Vienna (see Kysilka, 2007, p. 22-23). $85 \%$ of the price was based on the commodity price, while the remaining $15 \%$ was based on the costs of transportation, distribution, fees for market operators, etc.

In the Czech Republic, the gas trade is based on long-term contracts. $96 \%$ of natural gas supplies are provided by two companies. Moravské naftové doly, a. s. procures supplies from domestic production. These amount to less than $1 \%$ of the demand in total. RWE Transgas, a. s. has concluded contracts with OOO Gazprom Export, the supplier of Russian gas, until $2035^{100}$ and with a consortium of Norwegian producers (ExxonMobil Production Norway Inc., Statoil Hydro ASA, Norske ConocoPhillips AS, TOTAL E\&P NORGE AS and ENI Norge AS) until 2017 $7^{101}$. Finally, VEMEX s. r. o. has contracts with OOO Gazprom Export until 2012 with a possibility of further extension (see Zaplatílek, 2008, p. 5). RWE Transgas, a. s. procures natural gas transit through the Czech Republic as well as gas supplies for domestic purposes. Gas is being purchased at the Slovakian-Ukrainian transfer station Velke Kapusany and transported through Slovakia to the Lanzhot transfer station (see Mejstř́k \& Marková, 2010, p. 20). Since 2008, other companies have also started to import natural gas to the Czech Republic: Ceska plynarenska, a. s., which obtained the purchase contract for gas in Norway ( $0.1 \%$ of total Czech import of natural gas in 2008), company Lumius, spol. s r. o., which buys natural gas mainly in Germany ( $0.5 \%$ of total Czech import of natural gas in 2008) and the German company WINGAS GmbH \& Co.KG. (1.7\% of total Czech import of natural gas in 2008) (see MPO, 2009b, p. 39-40).

Although the expansion of suppliers of natural gas has become a modern trend ${ }^{102}$, the extent of contracts is still rather insignificant and it does not have a major impact on the gas market.

\subsubsection{The Transportation, Transit and Distribution of Natural Gas}

The only holder of a natural gas transportation license in the Czech Republic is NET4GAS, s. r. o. (until March 3, 2010 known as RWE Transgas Net, s. r. o.). NET4GAS, s. r. o. owns the pipeline network in the Czech Republic, while, in addition to the transit of Russian natural gas to the countries of Western Europe, it also provides supplies for particular regions run through the line of the transmission transportation system.

Most natural gas exported from the Russian Federation to the Czech Republic comes from the Russian Urengoy, Yamburg and Medvezhye giant gas fields. It flows through the Brotherhood and Yamal gas pipelines, which join the Soyuz pipeline in the Western Ukraine. These three bundles then become the Transgas system. The existing pipeline networks for Russian gas are built on foundations dating from the

100 Such a long-term contract between RWE Transgas and OOO Gazprom Export (until 2035) is nothing exceptional in Europe, as similar long-term contracts are concluded by OOO Gazprom Export and other suppliers with all major gas companies in the EU (such as GDF Suez, E.ON Ruhrgas AG, VNG Verbundnetz Gas AG, OMV Group, N. V. Nederlandse Gasunie, Eni S. p. A., Wintershall Holding GmbH, etc.) (see Kysilka, 2007, s. 22).

101 Contracts with companies that own the parts of the German gas network used for gas transport to the Czech Republic are also necessary. These companies include ONTRAS-VNG Gastransport GmbH and Wintershall AG.

102 In addition to RWE Transgas, a. s.; VEMEX, s. r. o. and Moravske naftove doly, a. s., the companies Ceska plynarenska, a. s.; Lumius, spol. s r. o.; WINGAS GmbH \& Co.KG.; United Energy Trading, a. s.; Energie Bohemia, a. s.; Conte, spol. s r.o.; SPP CZ, a. s.; LAMA INVESTMENTS, a. s., and Bohemia Energy Entity, s. r. o. in 2009 had a $3.66 \%$ share in natural gas supplies (see MPO, 2010g, p. 8). 
Cold War. The first pipeline was the multipurpose Brotherhood pipeline, completed in 1967. It fetched natural gas from western Siberia, from the Tyumen region. In the 1970s, the Transgas Company emerged, starting to develop and run pipeline networks, while the Transgas pipeline was released in 1972, consisting of several parallel pipelines set in different time intervals. ${ }^{103}$ Ever since, this road has been named the "system Transgas" (sometimes also known as the "classic route"). Gas travels mainly through the transit countries, Ukraine and Slovakia, while one of its parts is also supplied through the connector between the pipeline Yamal and Brotherhood from Belorussia to Ukraine. The gas is supplied from Slovakia to the Czech Republic using the Lanžhot border point, where it is delivered by the Slovak network operator Eustream, a. s. This system is peculiar in that the measuring devices are located as far as the Ukrainian-Slovak border, where the Czech Republic purchases gas. On the Slovak-Czech border, $7.5 \mathrm{bcm}$ per year (2008) for domestic consumption and $26.5 \mathrm{bcm} / \mathrm{y}$ for purchasers in the West (2008) is then passed on. The transit pipeline is interconnected with the German STEGAL network (operated by Wingas Transport GmbH) using the Hora Svate Kateriny border point. Gas has been supplied to Germany through this point since November 1999 (until then, it transited solely through Poland using the Yamal pipeline).

Natural gas from the Kingdom of Norway comes mainly from the Draupner E gas platform. The Europipe I pipeline $(18 \mathrm{bcm}$ per year; $660 \mathrm{~km})$ connects Draupner E directly with the German Dornum terminal. Another two pipelines, Europipe II (24 bcm per year; $658 \mathrm{~km})$ and Norpipe (16 bcm per year; 354 $\mathrm{km}$ ), then connect the terminal at Norwegian Kårstø with the German Dornum and Emden terminals (see Business Monitor Online, 2010). The gas is then transported using the NETRA pipeline (Norddeutsche Erdgas Transversale; 21,4 bcm/y; $408 \mathrm{~km}$; owned by the German company Verbundnetz Gas AG) through northern Germany to the Steinitz station and further to the Czech border, where it is transferred at the Hora Sv. Kateriny station. This gas is technically adjusted in Germany for the Czech pipeline network in terms of its interchangeability with Russian gas. The Russian gas is, therefore, basically pure methane, while the Norwegian gas contains more hydrocarbons and, consequently, has a higher calorific value ${ }^{104}$. Norwegian gas is mixed in Germany with gas extracted in Germany in order to reach a quality matching the Russian gas. On Czech territory, gas is provided for consumption in the northern and central regions and in Prague.

In reality, the supplies from Norway remain as "virtual" or "trade" gas during periods of continuous Russian gas flow rather than physical supplies. Norwegian gas is swapped for the Russian one, which is supplied to the Czech Republic either through the gas pipeline from Berlin to Hora Sv. Kateriny or through the Transgas system. In fact, Norwegian gas should only be supplied to the Czech Republic in the case of cutbacks or interruptions to supplies from Russia. During the crisis of January 2009, Norwegian gas was in fact the only gas actually flowing to the Czech Republic (viz Mejstř́k \& Marková, 2010, p. 19).

Basically, gas can be imported into the Czech Republic through three border points. The first is Lanzhot, used mainly for the transit of Russian gas to the Czech Republic. It can also be used for the purchase of gas on the spot market from the hub at Austrian Baumgarten an der March (Central European Gas Hub/ CEGH). ${ }^{105}$ The Czech Republic is not connected to the CEGH directly (there is nevertheless a project to construct an interconnecting gas pipeline from Breclav, see below); for this reason purchased gas is sent through the Slovak gas network Eustream, a. s. and from there through Lanzhot to the Czech Republic. ${ }^{106}$

103 For more details about the transit pipeline see Čech \& Tichý, 2001.

104 The amount of heat produced by the complete combustion of a material.

105 Central European Gas Hub (CEGH) AG, originally named Gas Hub Baumgarten, is a joint-stock company the shareholders of which are OMV Gas \& Power GmbH (80 \%) and Wiener Börse AG (20\%).

106 The maximum technical capacity of the cross-border point in Baumgarten is 0.00015232 million cubic metres per day as of January $2011(0.0000526 \mathrm{bcm} / \mathrm{y} ; 1601.2 \mathrm{GWh} /$ day $)$ for receipt of Russian gas from the Eustream, a. s. network and 0.00001658 million cubic metres per day $(0.00000573 \mathrm{bcm} / \mathrm{y} ; 174.3 \mathrm{GWh} /$ day $)$ for gas exports to the Eustream, a. $\mathrm{s}$. network (see ENTSOG, 2010a). 
The second point is Hora Sv. Kateriny with the two border points of Olbernau and Sayda. ${ }^{107}$ Gas, which flows to the Czech Republic from this point, includes Russian, Norwegian (in the form of substituted swapped Russian gas), as well as gas coming from Germany and Poland. In the future, the Nord Streampiped Russian gas will also pass through this point. The third existing border station is Waidhaus, which is mainly used for transferring Russian gas from the Czech transit network to Germany. It connects the Czech network with European pipelines using the MEGAL ${ }^{108}$ pipeline. It is also possible to use this station for the purchase of gas on the spot market. Also, gas from the planned LNG Adria terminal could be supplied through Waidhaus in the case of there being no interconnection through CEGH (see below). ${ }^{109}$

In 1972, the transit gas pipeline from Russia came into operation; it takes natural gas to Germany and France through the Czech Republic. Since 1972, therefore, the Czech Republic has been an important transit area due to its location. The owner of the Czech transit gas pipeline network is NET4GAS; this company also sets the transit fees (see NET4GAS, 2009). A producer of natural gas pays to the owner of the pipeline system for services of gas transmission through the pipeline system of a third country. For illustration, here it is the price for a steady daily transportation capacity during a one-year contract lasting for 12 months (table No. 5.3).

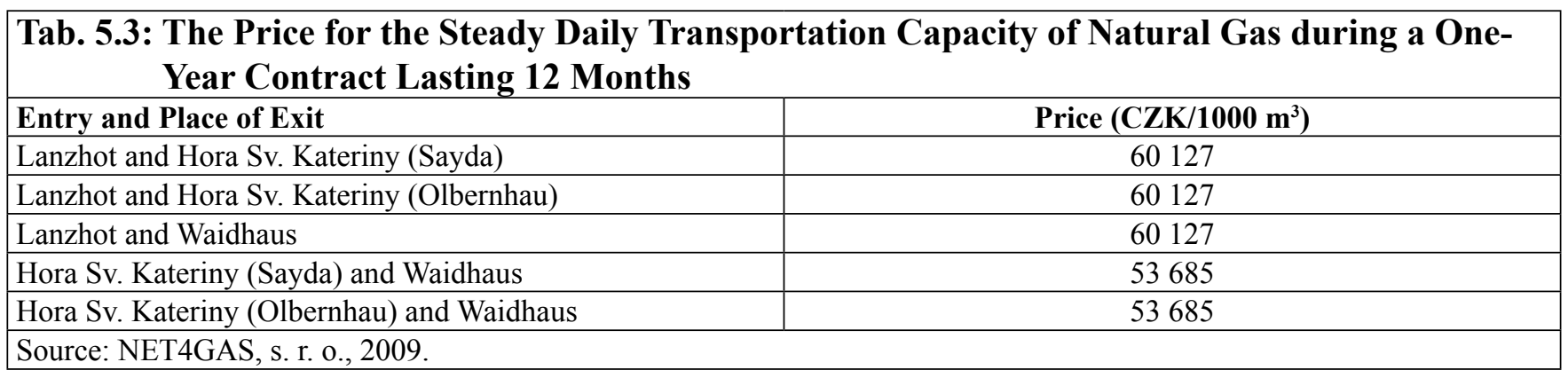

The volume of transited gas reached $72.5 \mathrm{mcm}$ per day (i.e. $26.46 \mathrm{bcm}$ per year) in 2008; it was 68.4 mcm per day in 2009 (i.e. $24.97 \mathrm{bcm}$ per year). Given the different types of transit contact, different transit tariffs, the lack of up-to-date data about the precise volumes of natural gas flows between the particular points across the borders and with respect to other circumstances, it is hard to calculate the concrete gains coming from the transit fees. The transit fees are, moreover, unregulated, they can also take the form of natural gas supplies and, if circumstances allow, they can provide a prosperous business.

Natural gas is transported through Czech and Polish territory mainly for consumers in Germany (38 $\mathrm{bcm} / \mathrm{y})$, Great Britain (20.9 bcm/y) and France (10.9 bcm/y). Smaller volumes are exported by Gazprom through the Czech Republic to Belgium $(4.9 \mathrm{bcm} / \mathrm{y})$ and the Netherlands $(6.7 \mathrm{bcm} / \mathrm{y})$. Supplies to Southern Europe are delivered using the pipeline in Slovakia going to Austria $(5.8 \mathrm{bcm} / \mathrm{y})$ through the hub in Baumgarten and further to Italy $(22.4 \mathrm{bcm} / \mathrm{y}) .{ }^{110}$

107 The subsequent German transit network is operated by the ONTRAS-VNG Gastransport GmbH company.

108 The capacity of MEGAL Süd is $22 \mathrm{bcm} / \mathrm{y}$ and is fully used year after year. MEGAL (Mittel-Europäische-Gasleitung) is operated by GRTgaz Deutschland GmbH, formerly Gaz de France Deutschland Transport GmbH, and E.ON Gastransport AG.

109 Adapted from Energetický regulační úřad, 2008 and MPO, 2009b. Revised by author.

110 Data from 2008 according to the OAO Gazprom website (http://gazprom.ru/). 


\subsubsection{Important Actors and Natural Gas Traders}

The biggest player on the Czech gas market is the German RWE concern (a member of GIE and GSE $^{111}$ ), owner of three key companies in the Czech Republic.

The first of them is RWE Transgas a. s., gas and power trader. RWE Transgas is responsible for two contracts for the purchase of natural gas from Russia and Norway and, at the same time, it organizes the purchase of natural gas for RWE Group customers in the Czech Republic. The second is NET4GAS, s.r.o., owner of the gas network in the Czech Republic that procures the transit of Russian natural gas to Western European countries as well as supplying gas to particular regions through the pipeline system. The third company is RWE Gas Storage, s.r.o., the biggest owner of underground natural gas storage facilities.

With regard to the difficulties which the parent company is going through, mainly the power producing companies RWE AG following the German decision to restrict the further exploitation of nuclear energy, the company decided to sell NET4GAS, s. r. o. for more than 41 billion CZK. The Consortium of Energy and Industry Holding and Australian Macquarie Funds, the Consortium of German Allianz Insurance Company and Canadian Borealis Investment Fund and KKCG Group were some of the interested parties. At the end of March 2012, the parent company decided to sell NET4GAS, s. r. o. to the German-Canadian Consortium (see Žižka, 2013).

Other important players include Česká plynárenská, a. s., E.ON Česká republika s. r. o. and VEMEX s. r. o.

Česká plynárenská a.s. was founded in January 2007 and began its activities on 1st April, 2007, when the gas market became fully liberalized. The company is one of the gas traders, and provides natural gas supplies and natural gas storage in the Czech Republic and further complex clearance of services. In the Czech Republic, the company focuses solely on direct supplies to licensed natural gas traders and on small and medium-sized businesses with many off-take points. It has an established cooperation and personnel interconnection with Ceska Energie, directed to the trade of electricity and associated services.

The companies E.ON Energie, a. s. and E.ON Distribuce, a. s. (operating under E.ON Česká republika, s. r. o.) have provided the regional distribution network and supplies to local customers in the South Bohemian Region since 2007. They belong to the German corporation E.ON AG with headquarters in Düsseldorf.

VEMEX s. r. o. is the main alternative supplier of natural gas in the Czech Republic. At the end of April 2010, VEMEX acquired $10 \%$ of the Czech natural gas market and became a member of the Czech Gas Union (see ČPU, 2010c). The German company ZMB GmbH is the majority owner of VEMEX $(51 \%)$ and is itself fully owned by the Russian OAO Gazprom. ${ }^{112}$ The remaining share is split between the companies Centrex Europe Energy \& Gas AG, which owns $33 \%$, and EW East-West Consult AG with a roughly $16 \%$ share. The company plans to enter the Slovak gas market and has already established a subsidiary company, VEMEX Energo s. r. o., with its headquarters in Bratislava.

111 Gas Infrastructure Europe and Gas Storage Europe. GIE is a European association of natural gas transport companies, natural gas storage facilities operators and LNG terminals operators. The association is divided into GTE, GSE and GLE. GTE (Gas Transmission Europe) represents transmission system operators (TSO) and consists of 35 companies from 26 countries. GSE represents storage system operators (SSO) and consists of 33 companies from 17 countries. GLE (Gas LNG Europe) represents European LNG terminal operators (TO) and consists of 15 companies from 10 countries (see Gas Infrastructure Europe).

112 Until recently, OAO Gazprom also owned a significant share (37.5\%) of Gas-Invest a. s. However, this company is currently in liquidation. 
Gas traders include RWE Transgas, a.s., Pražská plynárenská, a.s., E.ON Energie, a.s., Středočeská plynárenská, a. s., Severočeská plynárenská, a.s., Západočeská plynárenská, a.s. ${ }^{113}$, Východočeská plynárenská, a.s., Jihomoravská plynárenská, a.s., Severomoravská plynárenská, a.s. and from 1st August 2009 also the ČEZ Group. Apart from these, there are other gas-trading companies that can either buy gas directly from abroad and supply it to the final customers or purchase and sell gas already transported to the Czech Republic. Important traders that have already acquired final customers include VEMEX, s. r. o.; LAMA INVESTMENTS, a. s.; Česká plynárenská, a. s.; VNG Energie Czech, a. s.; United Energy Trading, a. s.; Moravské naftové doly, a. s.; Lumen Energy, a. s.; Lumius, spol. s r. o.; Energie Bohemia, a. s.; Quantum Vyškov, a. s.; Česká energie, a. s.; Wingas GmbH \& Co.KG.; Conte, spol. s r.o.; SPP CZ, a. s., Bohemia Energy Entity, s. r. o. and others.

\subsubsection{Underground Natural Gas Storage}

Three operators of underground gas storage facilities exist in the Czech Republic. RWE Gas Storage, s. r. o., owns six out of eight storage reservoirs located in the Czech Republic (Háje, Dolní Dunajovice, Tvrdonice, Lobodice, Štramberk and Třanovice). These six reservoirs are connected to the gas pipeline network and the company labels them as one Virtual Gas Storage Reservoir (see Veleba, 2007, p. 4). The Uhřice Reservoir is owned and operated by Moravské naftové doly Gas Storage a. s. - this company also operates the last reservoir in the Czech Republic, Dolní Bojanovice. This reservoir is nonetheless owned by SPP Bohemia, a. s. The reservoir at Dolní Bojanovice has a capacity of $576 \mathrm{mcm}$ and, technically, it is connected to the Czech gas pipeline network. However, according to a long-term contract from 1999, its storage capacity is used by Slovakia. Accordingly, the Czech Republic leases some of the capacity of the Láb I-III reservoir located in Slovakia and operated by Nafta, a. s. In addition to its great capacity, this reservoir is specific for its own border point Mokry Haj, which links it to the Czech system ${ }^{114}$.

If we do not take into account the Dolní Bojanovice reservoir, which is used by Slovakia, the overall capacity is $3 \mathrm{bcm}$. With respect to Czech requirements, which in 2009 made 8.161 billion $\mathrm{m}^{3}$ (see MPO, $2009 \mathrm{~g}$, p. 4), this is the amount covering more than a third of the entire yearly demand for natural gas (namely $36.8 \%$ ). In terms of the ratio between the amount which can be stored and yearly consumption, the Czech Republic with its reservoirs is in second place in Europe right behind Germany. Security positives (in addition to the coverage of potential supply curtailment, also the capability to balance the differences between supply and demand or resistance to weather impacts) based on the existence of underground reservoirs are, however, closely tied to the amount of gas which is stored in them. Natural gas is filled into reservoirs during the summer months when demand declines due to the warm weather. The filling process lasts 2-3 months. Important information is, however, to be read in their total daily extraction performance. During the winter period, reservoirs are, therefore, incapable of covering full daily consumption. In the Czech Republic, the maximum daily performance of reservoirs ranges from a maximum 50 million $\mathrm{m}^{3}$ at the beginning of the winter period to 33 million $\mathrm{m}^{3}$ at the end (see Zaplatílek, 2008, p. 6). Daily winter consumption in the Czech Republic is around $53 \mathrm{mcm}$. In the case of disruption to supplies from Russia, the shortfall between extraction from reservoirs and consumption is covered using supplies from Norway or Germany (see ČPU, 2009b). The speed of extraction from reservoirs is determined by an extractability curve. Because of the declining pressure, the speed of extraction declines proportionately

113 The fusion of Středočeská plynárenská, a. s., Severočeská plynárenská, a.s., Západočeská plynárenská, a.s on June 1st, 2009 resulted in establishment of a new company, RWE Energie, a. s. (see Hladíková, 2009, s. 202)

114 Czech traders may also use some of the underground gas storage reservoirs owned by WINGAS GmbH \& Co. KG and Verbundnetz Gas AG in Germany as well as the reservoir owned by WINGAS GmbH \& Co. KG in Austria (see Petržilka \& Kastl, n.d., s. 160). 
with the period of that extraction. ${ }^{115}$

A gas company providing the Czech Republic with gas has two alternatives - either to buy the amount of gas which is currently necessary, but risk that the price of purchased gas will be considerably higher, or to choose a cheaper option - to secure an equal level of natural gas supplies during the entire year on a long-term contract basis with a producer and place the unconsumed gas into underground reservoirs during the summer months. That is why underground reservoirs present an important component of the instate gas system.

\begin{tabular}{|c|c|c|c|c|}
\hline \multicolumn{5}{|c|}{$\begin{array}{l}\text { Tab. 5.4: Underground Natural Gas Storage Reservoirs in the Czech Republic and their } \\
\text { Maximum Capacity as of January 1st, } 2009\end{array}$} \\
\hline Reservoir & Owner & Type of Reservoir & $\begin{array}{l}\text { Peak Withdrawal / } \\
\text { Injection Capacity } \\
(\mathbf{m c m} / \mathbf{d})\end{array}$ & Capacity (mcm) \\
\hline Lobodice & RWE Gas Storage, s. r. o. & Aquifer* & \multirow{6}{*}{$36.5 / 26.9$} & 177 \\
\hline Tvrdonice & RWE Gas Storage, s. r. o. & Depleted Field & & 460 \\
\hline Štramberk & RWE Gas Storage, s. r. o. & Depleted Field & & 480 \\
\hline Dolní Dunajovice & RWE Gas Storage, s. r. o. & Depleted Field & & 900 \\
\hline Háje & RWE Gas Storage, s. r. o. & Cavern** & & 64 \\
\hline Třanovice & RWE Gas Storage, s. r. o. & Depleted Field & & 240 \\
\hline Uhřice & Moravské naftové doly, a. s. & Depleted Field & $6 / 2.9$ & 180 \\
\hline \multirow[t]{2}{*}{ Dolní Bojanovice } & \multirow{2}{*}{\multicolumn{2}{|c|}{ Total in the Czech Republic: }} & $9 / 7$ & 576 \\
\hline & & & $51.5 / 36.8$ & 3077 \\
\hline \multirow[t]{2}{*}{$\begin{array}{l}\text { Láb I-III*** (Slo- } \\
\text { vakia) }\end{array}$} & Nafta, a. s., divize PZPP & Depleted Field & $27.5 / 22$ & 500 \\
\hline & & Total: & $79 / 58.8$ & 3577 \\
\hline \multicolumn{5}{|c|}{$\begin{array}{l}\text { * An aquifer is an underground layer of a water-bearing permeable rock from which groundwater can be extracted by using } \\
\text { a water well. An aquifer reservoir functions by pushing gas into the underground water-bearing bedrock so that that pressure } \\
\text { artificially causes water to be pushed to the lower layers thus creating space for natural gas to be stored. } \\
\text { ** A cavern reservoir is created artificially, usually in former salt and coal mines. Haje reservoir is built where uranium mines } \\
\text { originally lay. } \\
\text { *** The overall capacity of the reservoirs is } 2130 \mathrm{mcm} \text { of natural gas. Aside from Láb I-III, there is also the Láb IV reservoir } \\
\text { in Slovakia, owned by Pozagas a. s. This reservoir's capacity amounts to } 620 \mathrm{mcm} \text { and the maximum withdrawal and injection } \\
\text { capacity is } 6.85 \mathrm{mcm} / \mathrm{d} \text {. } \\
\text { Source: "GSE Storage Map"; Česká plynárenská unie, } 2009 \text { b; compiled by T. Vlček. }\end{array}$} \\
\hline
\end{tabular}

115 Underground reservoirs alone would not be able to cover the loss in the event of the gas crisis in January 2009 without affecting the population. On January 5, 2009, a day before the outbreak of the gas crises, there was 15 million $\mathrm{m}^{3}$ of natural gas supplied to the Czech Republic from Russia through the Slovakian network Eustream, a. s., another 4.3 million $\mathrm{m}^{3}$ from the underground gas reservoir in Slovakia Lab I-III, 5.3 million $\mathrm{m}^{3}$ from Norway via Hora Sv. Kateřiny, 1.0 million $\mathrm{m}^{3}$ from Germany through Olbernhau, 0.5 million $\mathrm{m}^{3}$ from Germany through Waidhaus and 20 million $\mathrm{m}^{3}$ from the Czech underground reservoirs. In total, it was 46.1 million $\mathrm{m}^{3}$ of natural gas. A week later, on January 12, 2009, when the crisis reached its peak, the composition of supplies was as follows: zero from Russia and Slovakia, 1.8 million $\mathrm{m}^{3}$ from PZP Lab I-III (another 3 million $\mathrm{m}^{3}$ were left to Slovakia), 19 million $\mathrm{m}^{3}$ from Norway and Germany via Hora Sv. Kateriny (for Slovakia), 33 million $\mathrm{m}^{3}$ from Germany through Olbernhau, 0.5 million $\mathrm{m}^{3}$ from Germany via Waidhaus (at the same time, 27 million $\mathrm{m}^{3}$ was exported through that route to Germany to cover its shortage as a result of the restriction of Russian gas supplies) and 34 million $\mathrm{m}^{3}$ from Czech underground reservoirs. During this period, the extraction capacities of the reservoirs were used to the maximum effect. At the peak of the crisis, the total gas supplies, therefore, jumped to 58.3 million $\mathrm{m}^{3}$. Because of the strong frosts, average consumption in December 2009 ranged around 47 million $\mathrm{m}^{3}$. With respect to the physical characteristics and extractability curve, the maximum extraction of reservoirs at the peak of the crisis reached 34 million $\mathrm{m}^{3}$. It is therefore evident that the reservoirs alone would be insufficient to cover consumption and that the importance of diversified supplies of natural gas from Norway proved itself exactly during this crisis (For data see Petržilka, 2009b). 
The capacity of the reservoirs should be increased to $4.3 \mathrm{bcm}$ by 2014 and cover almost half of the annual consumption of the country (see ČPU, 2009b). By 2018, it should be potentially increased to 4,459 $\mathrm{bcm}$. The figure including the reservoir Láb I-III in Slovakia would amount to $4,959 \mathrm{bcm}$.

RWE Gas Storage, s. r. o. plans to increase the capacity of its reservoirs by $500-670 \mathrm{mcm}$ from its own financial resources by 2014. The company plans to invest up to 7 billion CZK in this increase (see ČPU, 2009b). It also intends to increase the daily performance of the reservoir.

RWE Transgas gained a donation from the EU by winning the competition over the opponent Moravske naftove doly, a. s. The European donation amounts to 35 million Euros (approximately 900 million CZK) intended for reservoir incensement. All the finances are part of the special EU program framework which was in its bigger part for the energy and gas infrastructure purposes. The European Commission announced the Program in March 2009 in order to limit the impact of next potential curtailment of natural gas supplies and to enhance European energy infrastructure. The project of RWE Gas Storage, s. r. o. for executing the increase in reservoir's gas storage capacity was one among 43 projects selected in the field of the power and gas industry which obtained a donation as part of the European Energy Programme for Recovery (see ČPU, 2010a). RWE Gas Storage, s. r. o. used this support to increase the storage capacity of the underground gas reservoirs Tranovice and Tvrdonice.

Česká plynárenská, a. s. started to build a cavern reservoir of capacity $180 \mathrm{mcm}$ in August 2010 in the Rožná uranium mine in Dolní Rožínka. The investment worth 9 billion CZK is managed for Česká plynárenská by GSCeP (see "V Rožné vznikne", 2010). The company is planning another reservoir for $100-150 \mathrm{mcm}$ in Southern Bohemia near the town Okrouhlá Radoň. Moravské naftové doly Gas Storage a. s. plans to increase the capacity of its Uhřice reservoir by $150 \mathrm{mcm}$ by 2012. Mediated by VEMEX, s. r. o., in April 2008 it signed a memorandum with OAO Gazprom for construction of the new Damborice reservoir with expected capacity up to 300-370 million $\mathrm{m}^{3}$. Following some changes, in March 2013, Moravske naftove doly, a. s. and Gazprom Germania signed an investment agreement for construction of the Damborice underground reservoir with a capacity of 448 million $\mathrm{m}^{3}$. 


\begin{tabular}{|c|c|c|c|}
\hline $\begin{array}{r}\text { Tab. 5.5: Planne } \\
\text { Under }\end{array}$ & $\begin{array}{l}\text { d Projects to Increase the Cap } \\
\text { ground Gas Storage Facilities }\end{array}$ & $\begin{array}{l}\text { acity of Existing Reserv } \\
\text { in the Czech Republic }\end{array}$ & or to Develop New \\
\hline Reservoir & Owner and Investor & Increase in Capacity (mcm) & $\begin{array}{c}\text { Year of Completion of the } \\
\text { Project }\end{array}$ \\
\hline Lobodice & RWE Gas Storage, s. r. o. & - & - \\
\hline Tvrdonice & RWE Gas Storage, s. r. o. & $\begin{array}{l}+45 \\
+105\end{array}$ & $\begin{array}{l}\text { April 1st, } 2010 \\
2012\end{array}$ \\
\hline Štramberk & RWE Gas Storage, s. r. o. & - & - \\
\hline Dolní Dunajovice & RWE Gas Storage, s. r. o. & - & - \\
\hline Háje & RWE Gas Storage, s. r. o. & +14 & 2014 \\
\hline Třanovice & RWE Gas Storage, s. r. o. & +290 & 2012 \\
\hline Uhřice & Moravské naftové doly, a. s. & +150 & 2012 \\
\hline Dolní Bojanovice & SPP Bohemia, a. s. & - & - \\
\hline Rožná - Julie & $\begin{array}{l}\text { Česká plynárenská, a. s., investor } \\
\text { GSCeP, a. s. }\end{array}$ & 80 & $2017-2018$ \\
\hline Rožná - Sára & $\begin{array}{l}\text { Česká plynárenská, a. s., investor } \\
\text { GSCeP, a. s. }\end{array}$ & 100 & $2017-2018$ \\
\hline $\begin{array}{l}\text { Okrouhlá Radouň - } \\
\text { Helena }\end{array}$ & $\begin{array}{l}\text { Česká plynárenská, a. s., investor } \\
\text { GSCeP, a. s. }\end{array}$ & $100-150$ & $2015-2016$ \\
\hline Dambořice & $\begin{array}{l}\text { Moravské naftové doly, a. s., } \\
\text { with Gazprom Germania }\end{array}$ & 448 & 2016 \\
\hline Total new capacitie & s in the Czech Republic: & 1332-1382 & 2018 \\
\hline $\begin{array}{l}\text { Prospective total ca } \\
\text { cluding existing on }\end{array}$ & $\begin{array}{l}\text { lpacities in the Czech Republic (in- } \\
\text { s): }\end{array}$ & 4409-4459 & 2018 \\
\hline $\begin{array}{l}\text { Prospective total ca } \\
\text { cluding Láb I-III): }\end{array}$ & pacities of the Czech Republic (in- & $4909-4959$ & 2018 \\
\hline
\end{tabular}

\subsubsection{The Use of Natural Gas}

Czech consumption of natural gas has reached a level of $8.719 \mathrm{bcm}$ (2009) and $8.161 \mathrm{bcm}$ (2008). Households make up the biggest share by using gas for purposes such as cooking, individual heating and warm water. Industry is the second largest consumer, and mainly the sectors of the non-metallic materials industry, food and tobacco, engineering, iron and steel as well as the chemicals industry. Some consumption also occurs while using gas for heat generation and for the combined generation of heat and electricity (cogeneration). However, this volume is not substantial and there is significant space for growth. The use of natural gas inside the transportation sector, both in the form of compressed natural gas (CNG, 200 bars of pressure) and as liquid ( $\mathrm{LNG}$ at $-162{ }^{\circ} \mathrm{C}$ ), is only at its beginning. The $\mathrm{CNG}$ version is currently the most common. The development of natural gas use in the transport sector has been minimal so far, despite significant potential. 


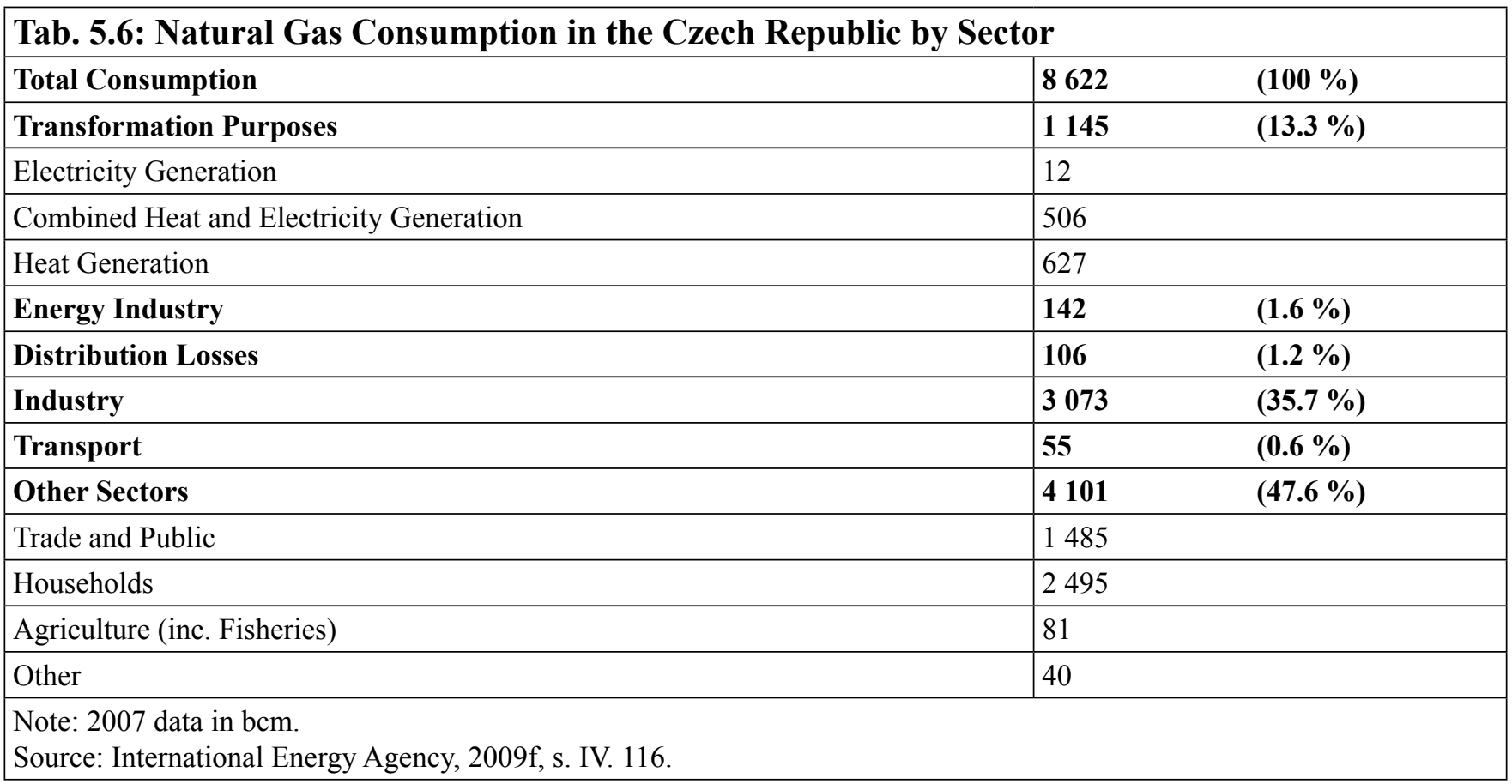

The exploitation of natural gas for electrical power production is rather modest in the Czech Republic. There is however a line of large combined cycle power plants in the Czech Republic which are at the planning stage. CEZ plans to build altogether three combined cycle power plants. The project in Pocerady was lunched on April 1, 2011, following installation of 838 MWe capacity, while the first electricity produced by the new plant is expected in June 2013. The investor and, consequently, the operator of the new plant will be CEZ Group. Skoda Praha Invest was selected as the main supplier. For supplying the main technological units during the combined cycle, SIEMENS was selected as a supplier of gas turbines, SES Tlmace as a supplier of gas generators and SKODA POWER as a supplier of steam turbines. The Melnik power plant in Horni Pocaply is the second project. The planned capacity amounts to $800 \mathrm{MWe}$, while the supplies should go to Melnik and Prague. The management of CEZ has already approved the business objective of constructing the new combined cycle plant and the project is currently at the stage of permit procedures (see ČEZ, a. s., 2011c). The last project is Uzin in the outskirts of Usti nad Labem (220 MWe), which has had a valid building permit for 12 years, but where the construction nevertheless faces the opposition of local politicians and residents (see Geussová \& Pravec, 2008).

RWE is also engaged in the construction of combined cycle power plants, planning the construction of the Mochov combined cycle power plant with a capacity of $1000 \mathrm{MWe}$ in Central Bohemia, not far from Celakovice., A “Commission Against Mochov Power Plant" was put together, initiated by the major of Celakovice, opposed to the construction of a power plant in a densely inhabited area. Despite serious protests, RWE is proceeding with its project according to the schedule. On January 19, 2011, RWE and CEPS signed an agreement to interconnect the planned Mochov power plant with the Czech transmission system, which regulates the terms, single preparation activities and realization of the power plant's attachment to the network (see RWE, 2011). The RWE (with headquarters in Germany) and Alpiq (Switzerland) energy concerns are the project investors, while the commercial opening of the power plant is expected in 2014. The investors are currently completing an EIA study on the power plant.

Further projects involving the construction of combined cycle power plants in the Czech Republic are the Prostejov combined cycle plants with a capacity of $82 \mathrm{MWe}$. The project was originally the product the now bankrupt Moravia Energo, a. s. The positive results of the Environmental Impact Assessments were 
known only after Moravia Energo was already bankrupt. The project was purchased by the Slovakian IN Group, which withdrew from the plan only a few months later. In February 2011, another Slovak company, Novacka Energetika from the Trens Group, took over the project (see verdík, 2011). Prazska energetika, a. s. was also preparing the construction of a combined cycle power plant in Prague's Bohunice with installed capacity of $50 \mathrm{MWe}$. The construction already had a number of permits when the energy company dropped the construction following strong resistance from local residents and politicians (see Švec, 2010, p. 1). The J\&T Finance Group has also announced its intention to build combined cycle sources of electricity with a total capacity up 200 MWe.

A combined cycle power plant and a gas and combustion power plant are not one and the same. While a gas and combustion power plant's functioning is based on the simple principle of natural gas combustion and use of generated energy to start turbines and produce electricity, a combined cycle power plant consists of two cycles. During the first (gas) cycle, natural gas is mixed with air and sent under pressure into a turbine, where it burns, heat is produced and consequently electrical power. Flue gases of high temperature are brought to a different boiler (second cycle) where thermal energy (steam) is produced and consequently electrical power as well. This production method increases energy efficiency since the generation of steam for the steam turbine uses the heat of the flue gases released from the gas turbine.

Combined cycle power plants have a $2.94 \%$ share (which is 590.72 MWe of installed capacity) in the Czech Republic's electro-energy mix, while the share of gas and combustion power plants amounts to $2.16 \%$ (i.e. 433.69 MWe of installed capacity). By December 31, 2010, natural gas had a 5.1\% share (1024.41 MWe of installed capacity).

The largest combined cycle power plant in the Czech Republic built so far is Vresova power plant (400 MW) owned by Sokolovska uhelna, pravni nastupce, a. s. The enormous advantage of this power plant is its capability to limit electricity output in an instant. It is able to reduce its output from $180 \mathrm{MW}$ to $2 \mathrm{MW}$ in a mere second ${ }^{116}$ (see Sokolovská uhelná, n.d.). The remaining sources beyond $50 \mathrm{MWe}$ are Teplarny Brno, a. s., (95 MWe) and Teplarna Trmice, a. s., (70 MWe).

\subsection{The Regulatory Framework of the Natural Gas Industry}

In terms of mining, the exploitation of natural gas is guided by Act No. 44/1988 Coll. on the protection and utilization of mineral resources (The Mining Act) (see "Zákon č. 44/1988 Sb.") and by the Czech Mining Authority, as in the case of coal. The trade with natural gas is treated in Act No. 458/2000 Coll., on business conditions and public administration in the energy sectors and on amendment to other laws (The Energy Act).

In the Czech Republic, the gas sector deals with the regulatory framework and conceptual materials very well, while it in many aspects (maybe naturally) even precedes them. None of the legislative materials in any manner deviates from the established course (in the field of natural gas), which also adds to this sector the necessary stable foundation which new projects and investments demand. Unlike the coal

116 It is a general advantage of gas fired power plants (not gas combined cycle power plants) which increases the importance of this sort of power plant in terms of their contribution to the management and stability of the entire electricity network. It is the first (gas) cycle, where natural gas is mixed with air and sent under pressure into a turbine, where it burns, that is easy to change the output in an instant. The second cycle is slow the same way as it is in coal fired power plants. When a gas combined cycle power plant is needed to be regulated in an instant, the second cycle must be shut down. 
or nuclear sectors, the natural gas sector does not have any important political or technical problems and that development of this sector is proceeding smoothly.

On November 12, 2009, a simulation of a state of crisis took place as part of preparations for new legislation on emergency situations. During the simulation, gas supplies were not restricted to any costumers. The then Minister of Industry and Trade, Vladimir Tosovsky, argued that "in the event of curtailment of natural gas supplies from Russia, the Czech gas industry would be capable of handling the situation in an adequate manner" (see Akrman, 2009). According to the regulations of Act No. 334/2009 Coll., on states of emergency in the gas industry, the management of the entire system is, in the event of an emergency, to be taken over by the operator of the transit network (NET4GAS, s. r. o.), who will then run it together with other companies until the standard supplies of natural gas are restored.

In the gasworks sector, the obligation (both local and supranational) to keep strategic reserves has not been implemented yet. This did not change until the introduction of the amendment to The Energy Law, when as Parliamentary report No. 232/4 it was approved by Parliament in June 2011 and signed by the president. This amendment definitively implements the Third EU Liberalization Package (mainly Directives 2009/72/EC and 2009/73/EC). Among other things it sets the obligation for gas traders to store in reservoirs a minimum of $20 \%$ of the natural gas volume which their costumers took in the previous twelve months. This new obligation, entering into force 30 days after the amendment had been announced, caused quite negative reactions, since a great part of the reservoirs was being used by RWE Transgas, a. s. for its own purposes. There are, therefore, a small number of free facilities for all the other suppliers, so they will have to use storage facilities beyond Czech borders, which can affect the price of natural gas for the end-user. It is, however, necessary to wait for real market reactions, since initial proclamations about emerging changes are always slightly overstated.

In the natural gas sector, the Czech Gas Union (ČPU) also plays an active role, founded as a corporate interest group on April 27, 1994. The CPU stands outside the legislative and regulatory sector, its goal is among other things to protect the trade interests of its members, to represent its members to the state administration, self-governed entities and in the public and to perform the function of an employer's union (see Česká plynárenská unie). Aside from the CPU, there is also the Czech Gas Association which is aims at the increasing professionalization of the gas field, mediating the transmission of information related to the gas industry and representing the Czech gas industry at an international level (for example, in the International Gas Union) (see Český plynárenský svaz).

Czech legislation relating (not only) to natural gas has been closely linked to EU legislation since 2004. EU legislation is presented in the form of packages and directives. There are a large number of them, which is why we in the further text discuss only those relevant to the gas industry sector. In addition to local particularities, the legal framework of the Czech Republic implemented EU legislative measures mainly at the turn of the century. The State Energy Concept and its revision, aside from domestic aspects (reserves of coal, nuclear energy, etc.) likewise reflect the very same European approach to the energy sector. The gas sector in the Czech Republic can generally be considered as properly regulated in terms of legislation. It reacts well to the legislative framework and conceptual materials and it also accurately deals with European legislation. In terms of natural gas, it is also clear that both domestic and EU legislation do not contradict each other and do not deviate from the long term course, by which they contribute to the stability of the sector as well as to the anticipation and preparation of further development.

All EU directives have been adopted in the Czech Republic and implemented in its laws. Particular problems of a technical and legal nature appeared during the initial liberalization of the electricity and gas sector following Directive 98/30/EC. Although it negotiated a delay in the Directive's implementation until 2008, the Czech Republic has carried its directions out successfully and had done so already in 2007. 


\subsection{Demand Forecast}

The Czech Republic has seen rather low growth in demand in recent years. This could change in the near future with predicted overall growth of demand for energy and especially with a decrease in the share of liquid and solid fuels in the TPES mix. This will be compensated by nuclear energy, renewable resources and natural gas. Natural gas will then, according to the SEP, become a much more important part of the TPES mix of the Czech Republic, accounting for approximately one fifth of the TPES mix. Aside from its use for heat and electric power generation, it will mainly be used in transport. The promotion of LNG and $\mathrm{CNG}$ is based on the program of alternative fuels for transportation issued by the European Commission in November 2001. The program presumes a gradual substitution of motor fuels based on oil with alternative fuels. It is expected that natural gas will by 2010 replace $2 \%$, by $20155 \%$ and by $202010 \%$ of total motor fuel consumption in the EU. The operation of 350,000 natural gas powered vehicles is planned by 2020. Gas consumption in the transport sector would then reach approximately $1 \mathrm{bcm}$. Natural gas is the only resource with a stable (approximately $20 \%$ ) share in all goals and scenarios.

\begin{tabular}{|c|c|c|c|c|c|c|c|c|}
\hline \multicolumn{9}{|c|}{$\begin{array}{l}\text { Tab. 5.7: The Shares of Solid, Liquid and Gas Fuels in Energy Resource Consumption According } \\
\text { to the State Energy Policy of the Czech Republic from } 2004 \text { and Its Update from } \\
\text { February } 2010 \text { and August } 2012 \text { (in \%) }\end{array}$} \\
\hline Type of Fuel & $\begin{array}{l}\text { Level in } \\
2000\end{array}$ & $\begin{array}{c}\text { Level in } \\
2005\end{array}$ & $\begin{array}{c}\text { Level in } \\
2008\end{array}$ & $\begin{array}{c}\text { Long-Term } \\
\text { Goal (SEP } \\
\text { 2004) by } 2030\end{array}$ & $\begin{array}{l}\text { "Green" } \\
\text { Scenario } \\
\text { (SEP 2004) } \\
\text { year 2030 }\end{array}$ & $\begin{array}{l}\text { Revised SEP } \\
(2 / 2010) \\
\text { Scenario by } \\
\quad 2030\end{array}$ & $\begin{array}{l}\text { Revised SEP } \\
\text { Scenario } \\
(2 / 2010) \text { by } \\
\text { 2050 }\end{array}$ & $\begin{array}{c}\text { Revised } \\
\text { SEP } \\
\text { (8/2012) } \\
\text { Target } \\
\text { Values by } \\
2040\end{array}$ \\
\hline Solid & 52.4 & 42.5 & 45.3 & $30-32$ & 30.5 & 24 & 20 & $12-17$ \\
\hline Gas & 18.9 & 21.6 & 15.7 & $20-22$ & 20.6 & 20 & 21 & $20-25$ \\
\hline Liquid & 18.6 & 15.7 & 20.9 & $11-12$ & 11.9 & 20 & 19 & $14-17$ \\
\hline Nuclear & 8.9 & 16.5 & 15.3 & $20-22$ & 20.9 & 25 & 25 & $30-35$ \\
\hline Renewables & 2.6 & 5.4 & 2.9 & $15-16$ & 15.7 & 11 & 15 & $17-22$ \\
\hline
\end{tabular}

The growth of natural gas demand is very well illustrated in the forecast of Business Monitor International (table No. 5.8), which by 2019 predicts its increasing consumption by more than $45 \%$ from 9.2 $\mathrm{bcm} / \mathrm{y}$ in 2011 to $13.4 \mathrm{bcm} / \mathrm{y}$ in 2019 . 


\begin{tabular}{|c|c|c|c|c|c|c|c|c|c|}
\hline Year & 2011 & 2012 & 2013 & 2014 & 2015 & 2016 & 2017 & 2018 & 2019 \\
\hline Consumption & 9.2 & 9.6 & 10.0 & 11.2 & 11.6 & 12.0 & 12.4 & 12.9 & 13.4 \\
\hline$\%$ change & 100 & 104.3 & 108.7 & 121.7 & 126.1 & 130.4 & 134.8 & 140.2 & 145.7 \\
\hline
\end{tabular}

Besides consumption for transportation purposes, the reasons for the increasing demand for natural gas can be observed in the development of combined cycle and gas and combustion power plants. The CEZ Group has launched the preparation of combined cycle projects mainly in North Bohemia, while the project located in Pocerady is in the most advanced phase, including two combined cycle blocks with a capacity of 838 MWe. It intends to invest 20 billion CZK in the construction of the project in Pocerady. In June 2009, the CEZ Group closed a construction agreement with Skoda Praha Invest. The power plant on which building work started on April 1, 2011, should be completed in June 2013. The Usti region, however, opposes this construction due to pollution of the environment and is asking CEZ to close another power plant in the region before opening it (see Sedláčková \& Adámková, 2009).

The localities intended for construction of combined cycle power plants are Melnik and Usti nad Labem - Uzin. Gas supplies to combined cycle power plants should be provided by RWE Transgas, a. s., with which the CEZ Group also has a 15-year deal (see Horáček, 2009).

According to the ČPU, projects to build seven combined cycle gas power stations are currently at different stages of development. Their total output will be 1820 MW (see "Bartuška”, 2010).

\subsection{The Current Issues and Projects in the Czech Gasworks Industry}

\subsubsection{The development of the Transmission System and of Cross-Border Interconnectors}

In 2008, the European Council presented the European Energy Programme for Recovery (EEPR). It is a plan supporting 47 projects in the EU energy field. ${ }^{117}$ For this purpose the European Union saved 3.98 billion Euros; however only 310 million Euros was invested into Central and Eastern Europe. The emphasis were mostly put on the natural gas and electrical power sectors - projects involving new interconnections between the member states, the construction and increasing of natural gas reservoirs and the installation or expansion of reverse flows - the support, therefore, went to infrastructure support in general. It is capital which RWE Transgas, a. s., RWE Gas Storage, s. r. o. and NET4GAS, s. r. o. are using to cover part of their projects.

The European Union supported NET4GAS, s. r. o. with approximately 9.5 million Euros for enhancing the network in the Czech Republic, whereas the capital was intended for enhancing energy security Central Europe as a whole(see Adámková, 2010b, p. 3). It was invested in three projects. 2.3 million Euros (about 60 million CZK) was allocated for increasing the flexibility of underground connections at

117 The list of supported projects is available at "The Commission proposes, " 2009. 
Tvrdonice and Dolni Dunajovice in Southern Moravia to the transit system. Another project increasing the capacity of the gas network pipelines for the reverse flow of gas towards Slovakia acquired 3,675,000 Euros (about 95 million CZK), while, as part of the joint project with the Polish company Gaz System S.A., the subsidies for the Czech Republic amounted to 3.5 million Euros (about 90 million CZK) for interconnecting the Ostrava region with Poland in the Tranovice-Chotebuz route (see CGU, 2010a).

The total investment for construction and maintenance of the network which NET4GAS, s. r. o. plans by 2020 amounts to 15 billion CZK (see Adámková, 2010b, p. 3).

The current infrastructure project which is closely tied to the construction of the Nord Stream Pipeline is the Gazelle pipeline. The Gazelle gas pipeline project is the biggest gas pipeline project (capacity amounting to $35 \mathrm{bcm}$ per year) that directly affects the Czech Republic. RWE Plynoprojekt, a. s. is the architect of the new Gazelle gas pipeline project, while NET4GAS, s. r. o. is its investor. The route will connect two border points, i.e. Hora Sv. Kateriny and Waidhaus. The gas pipeline is planned as a direct extension to the planned German pipeline OPAL (Ostsee Pipeline Anbindungs-Leitung) with a capacity of $35 \mathrm{bcm} / \mathrm{y}$, which follows the Nord Stream project ${ }^{118}$, bringing natural gas over the seabed from Russia's Vyborg to Germany's Greifswaldu. Nord Stream will be $1222 \mathrm{~km}$ long with a capacity of $55 \mathrm{bcm} / \mathrm{y}$, and OPAL $470 \mathrm{~km}$ long with a capacity of $35 \mathrm{bcm} / \mathrm{y}$. The pipeline with a capacity of $30 \mathrm{bcm} / \mathrm{y}$ and $166 \mathrm{~km}$ in length was put into operation in January 2013.

The gas pipeline should supply natural gas to southern and south-eastern Germany. The gas pipeline connection between the former East and West Germany is quite underdeveloped due to the separate development of these states during the Cold War. Thanks to this interconnection, however, the Czech Republic will be connected to the Northern Route.

NET4GAS, s. r. o. and Polish Gaz System S. A. want to build a high-pressure gas pipeline that connects the Ostrava region with the Polish Cieszyn County. The pipeline is $32 \mathrm{~km}$ long and interconnects the gas pipeline networks of both countries. Primarily, it is intended to carry supplies to the Polish market but is nevertheless designed to be bidirectional. The initial capacity is $0.5 \mathrm{bcm}$ and the pipeline was completed in 2011 (see Matocha, 2010). An increase to $3 \mathrm{bcm}$ per year by 2015 is planned. Half of the project's costs from a total of 28 billion Euros, was financed from EU funds, whereas 3.5 million Euros from theses funds was donated to the Czech Republic and the remaining sum to Poland. According to official statements, the pipeline should serve as the key feature in Polish energy diversification and the development of a NorthSouth Gas Corridor. Its capacity will nevertheless only be $0.5 \mathrm{bcm}$ per year. On the Czech side it will start from the underground gas storage facility in Třanovice and finish in Chotěbuz. From unofficial Polish sources it is evident that construction of the gas pipeline is motivated by economic rather than security interests. Poland has suffered from a long-term shortfall in natural gas supplies at a level of $0.5 \mathrm{bcm}$ per year, which is the capacity of the Moravia pipeline. Moreover, CEZ Nowa Skawina S. A. is attempting to build a new combined cycle gas power plant in the region by 2014. The Polish side sees the Moravia pipeline rather as a "quiet pipeline", which means that it would only be used during a crisis. Gas exports from the Świnoujście LNG terminal through Moravia have not yet been considered by Poland.

Three gas pipeline construction projects connecting the Czech Republic and Austria are now being considered. NET4GAS, s. r. o. plans to connect the Czech network to the Austrian station in Baumgarten:

118 The following companies are participating in the Nord Stream AG consortium: OAO Gazprom (51 \%), E.ON Ruhrgas AG (20\%), Wintershall Holding GmbH (20\%) and N.V. Nederlandse Gasunie (9\%). 
(1) The $60 \mathrm{~km}$ long LBL Gas Pipeline (Lanžhot - Baumgarten - Line, also-called BACI - Bidirectional Austrian Czech Interconnection) should start from Breclav, with estimated construction costs amounting to 80 million Euros (see Adámková, 2010b, p. 3). The planned initial capacity is $6.6 \mathrm{bcm}$ per year in bidirectional operation (see NET4GAS, s. r. o., 2010b). This gas pipeline would mean prospective connection to other projects such as Nabucco, South Stream or LNG Adria. Moreover, it will also represent competition for the Slovak transit gas pipeline owner Eustream, a. s. (see Petř́ček, 2009). Due to its prospective connection to various southern European gas pipeline projects, the Czech Republic is likely to increase its regional importance with regard to natural gas transit to Western markets.

(2) The second project also planned by NET4GAS, s. r. o. is the second branch of the BACI pipeline, ranging from the Southern Moravia (from the vicinity of Ceske Budejovice) to the town of Oberkappel on the German-Austrian border. The logic of the pipeline lies in the further disruption of the traditional eastwest route in favour of a new south-west connection. The company E.ON Ruhrgas AG was also thinking about this project (see Matocha, 2010).

(3) The Mozart Gas Pipeline leads from Jindrichův Hradec to the Austrian town of Rainbach, where it should be connected to the transit pipeline (WAG). This project is the work of Česká plynárenská, a. s. and should be completed by 2013. Investment costs are estimated at 2 billion Czech crowns (see Adámková, 2010b, p. 3). According to unofficial information, the company is, however, not interested in the construction itself but in sale of the entire project. The gas pipeline should serve mainly to connect Česká plynárenská's planned storage facility near the town of Okrouhlá Radouň to the Austrian gas pipeline network run by ÖMV.

In addition to the mentioned cross-border interconnectors, an intrastate pipeline called Moravia is planned as well. The pipeline should follow the route from Breclav (in Southern Moravia) to Pribor (the Ostrava region), where it would split into a branch leading to the underground reservoir in Tranovice and a branch leading to the Polish pipeline network. NET4GAS, s. r. o. is the project investor, while the beginning of the construction works is planned for 2015 (see Tramba, 2011). The pipeline is part of the north-south connection and it would play an important role in the potential growing independence of the Czech Republic from supplies from the East.

\subsection{Summary}

The level of diversification of natural gas supplies to the Czech Republic is high in the context of Central Eastern Europe. The domestic gas pipeline network is owned and managed by a strong private company, which invests in the maintenance and development of infrastructure as well as in new projects that enhance security of natural gas supplies to the Czech Republic. Underground storage facilities that have a capacity of more than a third of Czech annual consumption have turned out to be an important element in the security of gas supplies, and their development further strengthens this element.

The Czech Republic is provided with gas supplies on the basis of long-term contracts with producers, which limits its implementation of EU liberalization measures, but on the other hand provides stability and guarantees to both exporters and importers.

The geographical position of the country in providing gas transit to other European markets is equally important. While this position does not provide the country with any significant economic gains (although the money paid for transit goes to NET4GAS, s. r. o. and partly flows also to the Treasury via taxation), 
it does strengthen the country's geopolitical role in Europe. This position may be undermined by completion of the Nord Stream and construction of the South Stream gas pipelines, which bypass the traditional transit countries. Natural gas consumers in Germany, Denmark, France, and Great Britain have contracted gas supplies amounting to $21 \mathrm{bcm}$ using the Nord Stream gas pipeline long before its completion. This is a sound effort to secure the maximum stability of supplies, which proved problematic when passing through the classical route (the Brotherhood pipeline). After launching of the Nord Stream pipeline, a decrease in the volume of transited gas through the Czech Republic to the West can be expected. However, the Czech Republic's position as a transit country could actually become stronger after connection of the Czech network to the Austrian hub at Baumgarten and its subsequent connection to either of the southern gas pipeline projects (Nabucco or South Stream).

According to the Energy Information Administration (EIA), growth of total natural gas imports into the EU between 2000 and 2020 is expected to reach $200-250 \%$, i.e. from $180 \mathrm{bcm} / \mathrm{y}$ to $380-430 \mathrm{bcm} / \mathrm{y}$. An increase of Russian exports of natural gas to the European Union by $30 \%$, i.e. from $134 \mathrm{bcm} / \mathrm{y}$ to $165 \mathrm{bcm} / \mathrm{y}$ (according to Gazprom by $65 \%$, i.e. from $134 \mathrm{bcm} / \mathrm{y}$ to $200 \mathrm{bcm} / \mathrm{y}$ ), will simultaneously follow (see Götz, 2005 , p. 4). With respect to new pipeline routes, this suggests that the volume of Russian natural gas supplies transferred through the Czech Republic will not grow, but we should rather expect a moderate decline.

In the Czech Republic, natural gas is seen as an important resource that lowers dependence on oil as well as the share of coal in the TPES. The gas industry is currently being supported to a significant level. The Czech Republic is thus heading towards more intensive use of natural gas while also maintaining security and stability of supply. This increased awareness of the need for security not only pertains to projects related to natural gas, but is also a general trend in the Czech energy sector. When it comes to domestic consumption, most gas is used by private households, then by industry, and, finally, in heat and electric power generation. The potential of natural gas lies mainly in the secondary regulation of the fuel and energy base for the coverage of fluctuations within the networks; in the long-term, the transport sector is also a promising area for growth.

By following the established course and by finalizing the abovementioned projects, natural gas will as part of the Czech fuel energy mix become an even more important energy commodity in the future with an entire range of positive properties.

The synthesis and analysis of the abovementioned information can bring us to the following summary of the Czech gas industry sector. The Czech Republic as part of Central-Eastern Europe benefits from a good geographical and transit diversification of supplies, i.e. of consumers' security in the event of a short-term crisis related to a considerable reduction or restriction of supplies. The ongoing integration of the Czech pipeline network and planned development of transit routes from/to resource regions in Western (Gazela), Northern (Nord Stream, LNG Świnoujście) and Southern (Baumgarten, Nabucco, South Stream, LNG Adria) Europe will enhance the geographical diversification of supplies even further. The great capacity of reservoirs capable to cover up to $36.8 \%$ of domestic gas consumption represents an important guarantee for consumers' security, should a crisis related to a reduction or restriction of supplies be repeated.

A positive and not insignificant impact on the security of gas supplies to the Czech Republic comes from the fact that not only has the Czech Republic closed long term supply contracts ( $70 \%$ of supplies are subject to agreement until 2035), but it has also signed long-term agreements for transit through the Republic towards consumers in Western Europe. The Czech Republic will, therefore, with great likelihood remain an important transit country, while the natural gas producers will continue using Czech territory for transit purposes, which is by itself a safeguard of the maintenance of supplies for its own needs. A contributing factor is also that the Czech Republic is a reliable and unproblematic transit country. 
The long-term contracts with suppliers however limit its liberalization efforts. If the greatest part of natural gas is provided to the Czech Republic on the basis of long-term contracts, intrastate liberalization and the growth of new traders would de facto face the fact that one and the same gas is being traded only with more mediators in between. VEMEX, s. r. o., Ceska plynarenska, a. s., Lumius, spol s r. o., WINGAS GmbH \& Co.KG., United Energy Trading, a. s.; Energie Bohemia, a. s.; Conte, spol. s r.o.; SPP CZ, a. s.; LAMA INVESTMENTS, a. s., and Bohemia Energy Entity, s. r. o., are exceptions as they arranged their own contracts for natural gas supplies from exporters. The range of contracts is, however, so far insignificant and has no (aside from VEMEX s. r. o.) greater impact on the gas market. Liberalization is thus still incomplete and it will not take place in an effective manner in the coming period either.

The Czech Republic takes an active part in solving the problems within the natural gas sector, both at state level by providing sufficient political support to natural gas and by relatively unproblematic implementation of the EU legislation in acts and regulations, as well as on the enterprise level through investments directed at the development and maintenance of networks and new projects related to natural gas (strategic reservoirs, transportation sector, etc.). This approach has had a positive impact on the development of the Czech gas industry and limits the risk of its stagnation. The great majority of the gas sector is in the ownership of a strong and stable European company (RWE) which is, among other things, engaged in the development of the LNG project in North Africa, taking part in the building of the LNG terminal in Rotterdam, the LNG terminal project in Wilhelmshaven as well as in the Nabucco project. In that manner, the risk of bankruptcy or sale of the Czech gas pipeline network for financial reasons is low. However, we should point out that the entire gas transit network, which is six out of eight distribution companies in the region, six out of nine underground reservoirs, a great majority of contracted natural gas arriving from Norway and Russia as well as the management of the entire system in a state of emergency (approximately $80 \%$ of the sector), is in the full ownership and control of the only dominant company, the Concern RWE AG, which, moreover, has its headquarters beyond Czech borders (in Germany). The risk that RWE Transgas, a. s. might abuse its dominant position, give advantage to the parent country or sell the Czech gas system to a third party should not be discounted so easily.

Insignificant domestic production (app. $1 \%$ ) means a constant dependence on natural gas imports with all the negative impacts which that brings. In the case of excessive extraction of natural gas at the expense of other energy resources, the Czech Republic will become even more exposed to the risk of natural gas price fluctuations, tied to oil. Moreover, the risk of potential unbalanced energy mix and thus the impacts caused by potential curtailment of natural gas supply grows. A significant level of total import dependence (27.5\%), and by assuming its further growth (by 2030, up to $60 \%$ ) also means an increase of Czech sensitivity to threats related to supply disruptions, fluctuations of the energy commodity prices and the increasing financial costs of arranging a sufficiency of energy materials.

The Czech Republic has the potential to use the EU interest in natural gas in a more profound fashion, since natural gas represents a precondition for the development of the gas industry of all EU member states. That fact together with appropriate measures carried out by the state (revision of the State Energy Concept from February 2010) speaks of the need to reach a capacity of $40 \%$ of yearly consumption in gas reservoirs within Czech territory by 2015, the capacity of mining performance during a one month period in the amount of at least $70 \%$ of average daily consumption in the winter period, to arrange the conditions for the operation of the transmission system in the opposite direction, etc.) and along with proper incentives coming from the private sector (underground reservoirs, infrastructure, interconnectors, gas and steam power plants and the like) represent an important opportunity for further investment in the Czech gas sector. 
The position of the Czech Republic as a transit gas country will increase once the numerous infrastructural interconnecting projects with Austria (among others, connection to the Central European Gas Hub in Austria's Baumgarten an der March), Poland (connection with LNG Świnoujście via the Moravia and Stork pipelines) and Germany (completed connection to the Nord Stream Pipeline via the OPAL and Gazela Pipelines) will be completed. The Czech Republic will benefit from a good geographical and geopolitical position in Central Europe. In that regard, there is, however, a potential threat of losing its important transit position as a result of incomplete infrastructure projects which have been planned, or due to the reduced exploitation of the existing gas network for the import and transit of Russian gas.

If the sector develops according to the desired trend, we can, for transit purposes rather expect growing dependence of other European countries on the Czech pipeline system. The result might be stronger support of Czech gas diplomacy for exporters, primarily the Russian Federation. The Czech Republic is part of the European Union, meaning that problems related to the supplies for the EU will, with the growing importance of the Czech Republic as a transit country, threaten other important countries, which is why stronger EU support can be expected both during crises and at points of development and maintenance of the transit infrastructure. 



\section{Chapter 6: The Nuclear Sector}

Tomáš Vlček

\subsection{Nuclear Power Plants in the Czech Republic}

There are two nuclear power plants running in the Czech Republic using a total of six pressurized reactors cooled and moderated by light water. The Dukovany nuclear power plant is located in Southern Moravia with four VVER ${ }^{119} \mathrm{~V} 213$ pressurized reactors (after modernization, installed power capacity currently amounts to 4 x $510 \mathrm{MWe}$ ), which provided its first electricity in May 1985, while the Temelin nuclear power plant is located in Southern Bohemia, a set of two VVER 1000 V 320 pressurized reactors (installed capacity equal to $2 \times 1,000 \mathrm{MWe}$, which was completed in December 2000. Both power plants are owned by CEZ. Thanks to the modernization of the technical part of the nuclear blocks, the power plants as of December 31, 2012, reached 4,404 MWe of installed electrical capacity and, therefore, made up a $19.7 \%$ share in the electrical power mix of the Czech Republic (in terms of installed capacity).

\begin{tabular}{|c|c|c|c|c|c|c|c|c|c|}
\hline Locality & $\begin{array}{l}\text { Blocks } \\
\text { marked } \\
\text { as }\end{array}$ & $\begin{array}{l}\text { Installed } \\
\text { capacity } \\
\text { (MWe) }\end{array}$ & $\begin{array}{c}\text { Type of reac- } \\
\text { tor }\end{array}$ & $\begin{array}{c}\text { Total } \\
\text { installed } \\
\text { capacity } \\
\text { (MWe) }\end{array}$ & $\begin{array}{c}\text { Total } \\
\text { installed } \\
\text { capacity } \\
\text { (MWt) }\end{array}$ & $\begin{array}{l}\text { Start } \\
\text { up }\end{array}$ & $\begin{array}{c}\text { Distri- } \\
\text { bution } \\
\text { company }\end{array}$ & $\begin{array}{c}\text { Voltage } \\
(\mathrm{kV})\end{array}$ & $\begin{array}{c}\text { Distri- } \\
\text { bution } \\
\text { point }\end{array}$ \\
\hline \multirow{4}{*}{$\begin{array}{l}\text { D u k o v a }- \\
\text { ny Nuclear } \\
\text { Power Plant }\end{array}$} & 1 & 510.0 & $\begin{array}{l}\text { VVER 440, } \\
\text { V } 213 \text { type }\end{array}$ & \multirow[t]{4}{*}{2,040} & \multirow[t]{4}{*}{5,500} & \multirow[t]{4}{*}{$\begin{array}{c}1985- \\
1988\end{array}$} & \multirow[t]{4}{*}{ CEPS } & \multirow[t]{4}{*}{400} & \multirow[t]{4}{*}{ Slavetice } \\
\hline & 2 & 510.0 & $\begin{array}{l}\text { VVER 440, } \\
\text { V } 213 \text { type }\end{array}$ & & & & & & \\
\hline & 3 & 510.0 & $\begin{array}{l}\text { VVER 440, } \\
\text { V } 213 \text { type }\end{array}$ & & & & & & \\
\hline & 4 & 510.0 & $\begin{array}{l}\text { VVER 440, } \\
\text { V } 213 \text { type }\end{array}$ & & & & & & \\
\hline \multirow{2}{*}{$\begin{array}{l}\text { Temelin Nu- } \\
\text { clear Power } \\
\text { Plant }\end{array}$} & 1 & $1,000.0^{*}$ & $\begin{array}{l}\text { VVER } 1000, \\
\text { V320 type }\end{array}$ & \multirow[t]{2}{*}{2,000} & \multirow[t]{2}{*}{6,000} & \multirow[t]{2}{*}{2002} & \multirow[t]{2}{*}{ CEPS } & \multirow[t]{2}{*}{400} & \multirow[t]{2}{*}{ Kocin } \\
\hline & 2 & $1,000.0^{*}$ & $\begin{array}{l}\text { VVER 1000, } \\
\text { V320 type }\end{array}$ & & & & & & \\
\hline
\end{tabular}

* In May, 2012, all the blocks of the Dukovany power plant were modernized, so its installed capacity increased from 4 x 440 MWe to 4 x 510 MWe. In 2007, the Temelin power plant underwent a modernization of turbines, so its capacity can range at the level of $2 \times 1,020$ to $1050 \mathrm{MWe}$, depending on circumstances (such as, for example, the temperature of the cooling water). Source: Energetický regulační úřad, 2010b, p. 89; revised and modified by T. Vlček.

119 VVER means water cooled, water moderated energy reactor (or water - water energy reactor), in Russian Vodo-Vodjanyj Energetičeskij Reaktor. In Western Europe and elsewhere in the world also known as PWR (Pressurized Water Reactor). 


\subsection{Deposits, Mine Production, Companies and Traders}

Uranium mining has a long history in the Czech Republic, which is currently the only European country still mining it. Of seven registered deposits, only the Rozna Deposit is still being mined. There is only one company engaged in uranium mining, namely DIAMO, state enterprise ${ }^{120}$ (until May 1, 1992, known as the Czechoslovakian Uranium Industry, state enterprise).

DIAMO, state enterprise, was founded in 1946, and is under the full control of the Ministry of Industry and Trade of the Czech Republic, and headed by Jiri Jez since July 5, 2000. DIAMO provides, among others, mining activities and activities implemented by mining means, specifically, mining, the treatment and processing of radioactive minerals, remediation works, the removal of the consequences and the impact of mining and processing of uranium ores, base metals and coal, and the technical and biological recultivation of devastated properties after decommissioning works (see DIAMO s.p.). DIAMO, with its headquarters in Straz pod Ralskem, comprises of four divisions, while the GEAM division runs the uranium mining.

The Czech Republic used to be among the most important world producers of uranium. A historical total production of almost 111 thousand tonnes of uranium in the form of sorted ores and chemical concentrate in $1946-2009$ made it the $10^{\text {th }}$ biggest producer in the world. Unambiguously the dominant source of uranium is the Rozna deposit in Dolni Rozinka (216 tonnes of concentrate in 2011), while a small percentage of the overall mining comes from the remediation works in the Straz pod Ralskem deposit (25-30 tonnes per year, see MŽP / ČGS-G, 2010, p. 197) and management of mining waters at six locations in Pribramsko (12.58 tonnes of metal in 2009, see DIAMO s. p., 2010, p. 11). The Rozna mine was supposed to be shut down in the mid-1990s, when uranium experienced a sales crisis as the previously important customer, Slovakian Power Plants, refused to purchase Czech uranium and started obtaining enriched nuclear fuel directly. Government Decrees from 1994, 1997, 2000, 2002 and 2005 gradually prolonged the mining period in Dolni Rozinka, while the Government by passing Decree No. 565 from May 27, 2007, extended the mining and processing of uranium in the Rozna deposit for as long as mining remained economically effective $^{121}$, and the termination of mining is tied to the results of a profitability assessment ${ }^{122}$, currently set for 2018. Given that one of potential deep geological repository localities is at the Dolni Rozinka site (Kravi hora), should it be selected, moving the employees from uranium mining to the construction of a deep geological repository is being considered.

120 The term DIAMO is an abbreviation for ammonium diuranate, in Czech Diuranát amonný.

121 According to its methodology, the International Agency for Atomic Energy considers economically efficient such mining as does not exceed a cost of 130 USD per to mine $1 \mathrm{~kg}$ of uranium.

122 DIAMO, state enterprise, carries out a mining profitability assessment every half year, and when it reaches negative figures, activity will be immediately terminated. Mining can be ended in several months on a regular basis, while remediation can, however, last for a decade. 


\begin{tabular}{|l|c|c|c|c|c|c|c|}
\hline \multicolumn{1}{|l|}{ Tab. 6.2: Deposits, reserves and mine production of uranium in the Czech Republic } \\
\hline & $\mathbf{2 0 0 5}$ & $\mathbf{2 0 0 6}$ & $\mathbf{2 0 0 7}$ & $\mathbf{2 0 0 8}$ & $\mathbf{2 0 0 9}$ & $\mathbf{2 0 1 0}$ & $\mathbf{2 0 1 1}$ \\
\hline Deposits - total number & 7 & 7 & 7 & 7 & 7 & 7 & 7 \\
\hline - exploited & 1 & 1 & 1 & 1 & 1 & 1 & 1 \\
\hline Total mineral reserves & 135,990 & 135,812 & 135,729 & 135,553 & 135,425 & 135,361 & 135,276 \\
\hline - economic explored reserves & 1,655 & 1,671 & 1,677 & 1,545 & 1,426 & 1,416 & 1,406 \\
\hline - economic prospected reserves & 19,411 & 19,476 & 19,435 & 19,428 & 19,420 & 19,427 & 19,402 \\
\hline - potentially economic reserves & 114,924 & 114,665 & 114,617 & 114,581 & 114,579 & 114,518 & 114,468 \\
\hline - exploitable (recoverable) res. & 596 & 677 & 643 & 503 & 377 & 374 & 338 \\
\hline Mine production & 420 & 383 & 322 & 290 & 286 & 259 & 252 \\
\hline Production of concentrate & 409 & 358 & 291 & 261 & 243 & 237 & 216 \\
\hline
\end{tabular}

Note: reserves, mining and the production of uranium concentrate expressed in tonnes, the production of uranium concentrate resulting from remediation works is not included in these values.

Source: Ministerstvo životního prostředí / Česká geologická služba - Geofond, 2010, p. 185; Ministerstvo životního prostředí / Česká geologická služba - Geofond, 2012, p. 102.

Since clean uranium in the Czech Republic at the present accounts for an average of $0.16 \%$ of uranium ore ${ }^{123}$, first it needs to be cleaned of waste rock. Cleaned up ore is then ground and, following chemical treatment with sulphuric acid, processed into uranium concentrate - triuranium octoxide $\mathrm{U}_{3} \mathrm{O}_{8}$ (or yellow cake $\left.{ }^{124}\right)$. DIAMO's intermediate product was purchased predominately by a single customer, namely CEZ. ${ }^{125}$ In 2009, it bought a total of 270.4 tonnes of concentrate (see DIAMO s. p., 2010, p. 2). CEZ has been in the last 15 years almost the exclusive user of uranium concentrate (the production surplus was at the beginning of the 1990s sold on the world market). Domestic production, however, did not satisfy CEZ's demands as the use of uranium concentrate in the Dukovany and Temelin nuclear power plants ranges between 600 and 700 tonnes per year (MŽP / ČGS-G, 2010, p. 197). CEZ, therefore, either buys additional supplies on the world market or it directly purchases enriched fuel.

At the start of 2000 , domestic mining covered approximately $93 \%$ of domestic demand. Currently, however, it is only a third of consumption as a result of the inhibition program, while the remaining supplies are bought on the world market in the form of concentrate of already enriched fuel (see MŽP/ČGS-G, 2010 , p. 200). Since the end of 2009, when the Russian company OAO TVEL began supplying fuel for both Dukovany and Temelin nuclear power plants, CEZ has been purchasing only the final product, enriched fuel, while DIAMO sells the domestic products on the market.

123 In the mid- $19^{\text {th }}$ century when the uranium mining was first initiated, uranium ores consisted of $65 \%$ uranium (see Majer, 2004, p. 183).

124 Yellow cake does not always necessarily have a consistent chemical formula $\mathrm{U}_{3} \mathrm{O}_{8}$ and a yellow colour. It got the name based on the look of uranium concentrate from the early mining and production period. Yellow cake is nowadays rather brown or black. $\mathrm{U}_{3} \mathrm{O}_{8}$, for example, has an olive-green colour. Chemical formulae of yellow cake can take forms such as: $\mathrm{U}_{3} \mathrm{O}_{8}, \mathrm{UO}_{2}, \mathrm{UO}_{3},\left(\mathrm{NH}_{4}\right)_{2} \mathrm{U}_{2} \mathrm{O}_{7} \cdot \mathrm{n} \mathrm{H}_{2} \mathrm{O}$ or $\mathrm{Na}_{2} \mathrm{U}_{2} \mathrm{O}_{7} \cdot 6 \mathrm{H}_{2} \mathrm{O}$. Yellow cake is transported in blue barrels. 


\begin{tabular}{|c|c|c|c|c|c|c|c|c|c|c|c|}
\hline Tab. 6. & NYM & X Ura & $\mathrm{um} \mathrm{Fu}$ & res Pri & of Ur & nium C & ncent & $\mathrm{e}\left(\mathrm{U}_{3} \mathrm{O}\right.$ & & & \\
\hline 2002 & 2003 & 2004 & 2005 & 2006 & 2007 & 2008 & 2009 & 2010 & 2011 & 2012 & 2013 \\
\hline 21.16 & 22.71 & 34.17 & 46.30 & 82.67 & 165.35 & 171.96 & 110.23 & 93.70 & 158.73 & 114.64 & 97.01 \\
\hline
\end{tabular}

At the point when CEZ started to employ exclusively a purchased concentrate, following the shift to uranium hexafluoride $\mathrm{UF}_{6}$ it had to search for sorting plants on the world market, i.e. for enrichment services. These can be obtained only in seven countries in the world ${ }^{126}$, and CEZ went to buy in France. Enrichment plants are capable of enriching supplied uranium hexafluoride according to the client's requirements. Uranium has a constant ratio of isotopes: it consists of $99.284 \%$ of ${ }^{238} \mathrm{U}, 0.711 \%$ of ${ }^{235} \mathrm{U}$ and $0.005 \%$ of ${ }^{234} \mathrm{U}$. However, it is isotope ${ }^{235} \mathrm{U}$ that has been so far almost exclusively employed for fission reactions and use in the nuclear industry. Enrichment is a process during which uranium gets a greater concentration of the ${ }^{235} \mathrm{U}$ isotope, which is for Czech nuclear purposes 3.6 to $4.4 \%$. ${ }^{127}$ From the point of mining through to enrichment, the volume of exploitable uranium in that manner rapidly declines. For initial processing, it is only $0.16 \%$ of mined material that is employable, while during the enrichment process at the level of approximately $4 \%{ }^{235} \mathrm{U}$, the volume of material lessens eight to eight and a half times $(650$ 680 tonnes of concentrate for Czech nuclear power plants turn into approximately 80 tonnes of $\mathrm{UO}_{2}$ fuel, see MŽP / ČGS-G, 2010, p. 200). In the case of uranium this is nevertheless an enormous energy density, where $1 \mathrm{~kg}$ of nuclear fuel generates $2,100 \mathrm{GJ}$ of energy, compared to $0.033 \mathrm{GJ}$ in the case of coal ${ }^{128}$ (see “Fyzikálni aspekty,” 2008, p. 24).

Enrichment is followed by the process of fabrication, where fuel gets processed into pellets $(1 \mathrm{~cm}$ in diameter and height) which are then fitted into fuel rods ${ }^{129}$, a specific number of which are then placed into fuel cassette (segments, assemblages). In the active zone of each reactor in the Dukovany nuclear power plant, there are 312 fuel cassettes, each weighing $215 \mathrm{~kg}$ and consisting of $137 \mathrm{~kg} \mathrm{UO}$ in 126 fuel rods, while the Temelin nuclear power plant has 163 fuel wrappers (cassettes ${ }^{130}$ ) in each reactor, each weighing $766 \mathrm{~kg}$ and consisting of $563 \mathrm{~kg} \mathrm{UO}_{2}$ in 312 fuel rods (each rod consists of approximately 370 pellets). In the active zone of the Dukovany nuclear power plant, there is, therefore, 42.7 tonnes of $\mathrm{UO}_{2}$ fuel, and 91.8 tonnes in the Temelin nuclear power plant. The fuel made in this manner is then supplied to the client, to CEZ.

The long-term and permanent fuel supplier for the Dukovany nuclear power plant is the Russian company OAO TVEL. From 2002, when the plant was launched, to the end of 2009, fuel for the Temelin nuclear power plant was supplied by the American company Westinghouse Electric Company, LLC ${ }^{131}$.

126 Sorted by capacity, the order is: Russia, the USA, France, Canada, the Great Kingdom, China and Brazil.

127 The Dukovany nuclear power plant has been during its entire operation period using fuel supplied by the Russian company OAO TVEL, which went through major development changes. Initial fuel with $3.6 \%{ }^{235} \mathrm{U}$ enrichment was employed in a three-year cycle, with an average calorific value of $30 \mathrm{MWd} / \mathrm{kg} \mathrm{U}$. A gradual improvement brought the plant to the zone of a low neutron spillage and $3.8 \%{ }^{235} \mathrm{U}$ enrichment. In the further phase, enrichment was lifted on $4.25 \mathrm{resp} .4 .38 \%$ ${ }^{235} \mathrm{U}$, while a burning absorber started to be used in fuel cassettes (see ČEZ, a. s., 2010b, p. 31) lowering fuel reactivity. Calculated by T. Vlček.

129 A length of a fuel rod for VVER 440 reactor is $242 \mathrm{~cm}$.

130 Cassette is a Russian term for a fuel wrapper.

131 It is known that fuel rod buckling takes place in the active zone of reactor, because American nuclear reactors have foursquared fuel cassettes, while the Russian ones are six-squared. Six-squared cassettes for Temelin were initially provided by Westinghouse Electric Company, LLC and caused fuel rods torsion, which resulted in forced operational interruption, limited production and inability to produce electricity to its full capacity. 
In 2010, a selection process for a new supplier took place, which was won by the Russian OAO TVEL by submitting a financially unbeatable offer. OAO TVEL will be until 2020, therefore, the exclusive fuel supplier for both Czech nuclear power plants.

Fuel used to be delivered to the Czech Republic by air from the USA or Russia ${ }^{132}$, while it is presently also transported by air from the Russian Federation and then by wagons to the target power plants ${ }^{133}$.

\subsection{Spent Fuel and the Nuclear Waste Repository}

Fission chain reactions exclusively consume the uranium isotope ${ }^{235} \mathrm{U}$. Spent fuel contains approximately a quarter of the original value of that isotope, which means that it remains enriched at a level of $1 \%$ ${ }^{235} \mathrm{U}$. Spent fuel consists of more than $96 \%$ of uranium dioxide $\left(\mathrm{UO}_{2}\right)$ and of newly emerged ingredients of plutonium(IV) oxide amounting to approximately $1 \%$ and other compounds (3\%), whereas the majority of fission products are radioactive isotopes (see Laciok, Marková \& Vokál, 2000, p. 190; Otčenášek, 2005, p. 536). Fuel assemblies with spent nuclear fuel that are removed from reactors look like fuel assemblies with fresh fuel. There are nuclear reactions taking place even after fuel is discharged from a reactor, as well as the release of alpha, beta and gamma radiation, neutrons and heat which must be exhausted.

The Dukovany nuclear power plant initiated its operation on the basis of a three-year fuel cycle. The increase of ${ }^{235} \mathrm{U}$ share in cassettes enabled it to reach a full five-year cycle (while even a six-year cycle is being considered). Nowadays this means that during the annual refuelling, only $1 / 5$ of spent fuel is replaced out of the overall charge, i.e. 72 fuel assemblies (see ČEZ, a. s., 2010a, p. 31).

The active zone in the Temelin nuclear power plant includes 163 fuel assemblies, while the power plant's operation is set on a four-year fuel cycle, which means that $1 / 4$ of spent fuel is replaced each year, i.e. 41-42 fuel cassettes (see ČEZ, a. s., n.d.a).

After removal from the reactor, three phases of fuel deposition follow. The first phase includes the collection of waste after its release from the primary circuit and subsequent processing until reaching treatable form preventing any further release of waste. The second phase includes safe transport to the location of final waste deposition. The third phase, deposition, is understood as the final operation, which is why the depository needs impenetrable protection shields (see Marek, 2007, p. 4).

In the first phase, fuel cassettes are actively cooled in a pool next to a reactor. After at least five years, they are moved into dry containers and then passively cooled in the interim storages. After removal from a reactor, the thermal capacity of spent nuclear fuel in the Dukovany power plant is $223.5 \mathrm{~kW}$ and then drops to $1 \mathrm{~kW}$ over the course of only one year (see Nachmilner, 2002, p. 12). The Dukovany power plant uses CASTOR 440/84 ${ }^{134}$ containers, supplied by the German Consortium GNS Gesellschaft für

132 In the 1990s, transport by sea via the Polish port Gdansk (from Russia) and then by railway to the final destination was also considered.

133 In Dukovany's case, for example, a cargo plane lands at Brno Turany International Airport, goes through the requisite customs and technical inspections and it is then reloaded onto the wagon and transported to the power plant under the police escort. 
Nuklear-Service $\mathrm{mbH}$ and RWE Nukem $\mathrm{GmbH}$, which can be filled with 84 fuel cassettes. ${ }^{135}$ A simple calculation based on the above-mentioned data can bring us to the conclusion that the Dukovany power plant produces less than a container of spent fuel per year. An empty container weights 93.7 tonnes and 116.1 tonnes when filled.

There are two interim storage facilities for spent fuel at the site of Dukovany nuclear power plant. The total capacity of the original Dukovany storage, opened in 1995, amounts to 600 tonnes of spent fuel stored in 60 CASTOR 440/84 containers. After filling this storage to its full capacity, in 2006, new storage was set up. Its capacity is 1,340 tonnes of spent fuel. In comparison to the first storage, the new one, therefore, incorporates approximately a two times larger area. The storage part of the facility can receive 133 CASTOR 440/84M containers, therefore, altogether allowing the Dukovany nuclear power plant to store spent fuel for 50 to 60 years, that is, for a period exceeding the lifespan of the power plant itself ${ }^{136}$ (see ČEZ, a. s., n.d.d; Marková, 1996, p. 626-627).

The Temelin nuclear power plant uses CASTOR 1000/19 containers from the same German suppli$\mathrm{er}^{137}$. They are 5.5 metres tall and when filled weigh approximately 116 tonnes. The Temelin power plant produces two full containers and 3-4 fuel assemblies of the third container of spent fuel per year. In 2010, a new interim storage facility was launched, with a capacity of 1,370 tonnes (152 CASTOR 1000/19 containers). ${ }^{138}$ The capacity of a dark wet pool for spent fuel is 680 fuel assembly places and 25 places for hermetic cases. Spent fuel could be, therefore, stored in the pool for ten years, which is why wet interim storage did not prove necessary before 2010. After its removal from a reactor, the thermal capacity of spent nuclear fuel is $964 \mathrm{~kW}$ and then drops to $5 \mathrm{~kW}$ in the course of only one year (see Nachmilner, 2002, p. 12). The Skalka central dry storage of nuclear fuel in the vicinity of Bystrice nad Pernstejnem was built as backup storage with an overall capacity of approximately 2,900 tonnes of fuel.

The second phase, transportation, is currently by rail, while it is subject to a very strict monitoring by the State Office for Nuclear Safety. While it is likely that spent fuel will also be transported by rail for a few decades, if deposited in deep geological repositories. This, however, cannot be claimed with certainty because it will depend on available technologies as well as the locality and access to the future deep geological repository.

Fuel is stored in dry interim storage for a period of approximately 80 years. The final deep geological repository (third phase) is for that reason in the Czech Republic scheduled not before 2065. There are four surface repositories in the Czech Republic, namely the Radioactive Waste Repositories Richard near Litomerice, Brotherhood near Jachymov, Dukovany and Hostim near Beroun. These repositories store institutional radioactive waste, emerging during the processes of medical, industrial, agricultural and

135 Spent nuclear fuel from the Dukovany nuclear power plant used to be transported to the interim storage at the site of the Jaslovske Bohunice nuclear power plant in Slovakia. From this location, it was meant to be gradually used up on the basis of the interstate agreement with the Soviet Union. Following the demise of the Soviet Union, the Russian Federation, however, withdrew from these commitments. After 1993, nuclear fuel from Dukovany was brought back to the country and placed in interim storage in Dukovany power plant.

136 The present power plant is licensed only until 2025. An application was submitted to prolong this license until 2035, while the prolongation until 2045 is also considered, but, as previously indicated, its shut down is predicted for 2045 at latest.

137 CASTOR 440/84 and CASTOR 1000/19 containers are presently produced in the Czech Republic as well. Their licensed producer is Skoda JS, a. s.

138 In addition to the Dukovany and Temelin power plants, a high-activity radioactive waste repository is operated also by the Nuclear Research Institute Rez, plc, where there are two research nuclear reactors operating (LVR-15 and LR-0). The capacity of the high-activity radioactive waste repository in Rez is substantially lower, as the Nuclear Research Institute produces only about 15 spent fuel segments per year. In 2007, all waste was transported to the Russian Federation, so this repository is currently empty. 
research activities, therefore, waste containing natural radionuclides and low-activity radioactive waste from nuclear power plants. One deep geological repository is planned as well.

In 1990-2005, the Radioactive Waste Repository Authority ${ }^{139}$ originally selected 27 potential localities for building a deep geological repository of radioactive waste. It narrowed them down to 13, then to 11 and finally to the current 7: Brezovy potok near Pacejovo, Certovka near Lubence, Horka near Budisov, Hradek near Rohozna, Cihadlo near Lodherov, Magdalena near Bozejovice and Kravi hora near Moravske Pavlovice. In recent years, the Authority has been checking the possibility of using military areas, while it was the Boletice military area that was positively valued in terms of its site, therefore, qualifying as an eighth possible appropriate location.

Since 2010, these localities have been undergoing a basic land survey, consisting of three phases: the first research phase until 2015, the second exploratory phase in the period 2015-2025 and the third detailed exploratory phase in the period 2025-2050. The exploration of at least four localities is anticipated, as the company is expected not to receive an exploration permit for all localities. By 2018, two candidate localities should be chosen, one of which will be then chosen as the winner. After obtaining enough data proving the locality's safety, the submission of the application for construction permit of a deep geological repository will follow, which should take place in the period 2050-2065 (see Správa úložišt' radioaktivnich odpadi). After this period expires, it will also be decided whether to process spent fuel from nuclear power plants and to use it as energy material for production of new fuel or if it is to be finally stored in a deep geological repository. ${ }^{140}$

Processing is nowadays technically, energy and financially a very costly process, which only a few countries in the world ${ }^{141}$ can afford, but the technology and initial costs can in the next 50 years however undergo such changes that it might become an entirely common practice. A deep geological repository is meant to be a final repository of spent nuclear fuel. It is questionable whether it should be technologically implemented so as make it impossible for already deposited waste to ever be picked up again or to enable deposited waste to be extracted and processed in the far future. Even though experts are rather inclined to the second alternative, because spent nuclear fuel represents a very valuable material which can be used as fresh fuel after being processed or even as fresh fuel without previous processing ${ }^{142}$, economic reality suggests the first alternative. The most expensive feature of a repository is its operation, which makes it economically unreasonable to keep a repository open for decades. This means it is better to store spent fuel on a long-term basis in interim storages and only when so decided, to deposit high-activity radioactive waste rather at once, and to do it finally (opening and using it again would be impossible). A deep geological repository is constructed under the assumption it will work for the next hundred years.

The owner of spent nuclear fuel in the Czech Republic is CEZ. It is responsible for storage only, while the final deposition is the state's responsibility. This was the purpose for founding the Radioactive Waste Repository Authority, which is on the basis of The Atomic Act responsible for the treatment of spent or ra-

139 Due to the transience of private companies, the final radioactive waste repository is not under CEZ's but the state's responsibility, specifically through the means of the Radioactive Waste Repository Authority (Czech: SURAO - Správa úložišt' radioaktivních odpadů).

140 Constructing a deep geological repository is a very complicated process which requires confident data regarding its locality. In terms of its radioactivity, spent fuel becomes safe at least 300 years after its removal from a reactor, which is accordingly the period for which a repository must function without difficulty. We can in that relation mention an interesting aspect of a nuclear sector, namely that spent fuel also alone protects itself against abuse, because its removal from the protection containers would, during this period, mean a deadly dose of radiation.

141 In 2011, it was only China, France, the Great Britain, India, Japan, Pakistan, Russia and the USA.

142 Some of the current fourth generation reactor projects plan to use previously spent fuel as a fuel. 
dioactive fuel into a form adequate either for deposition or for further use. The point when to deliver spent nuclear fuel to the state is exclusively CEZ's decision. So far, it is not radioactive waste but potentially exploitable material that is involved (see Laciok et al., 2000, p. 190-191).

\begin{tabular}{|c|c|c|c|}
\hline \multicolumn{4}{|c|}{ Tab. 6.4: Scheme of the End of the Nuclear Cycle in the Czech Republic } \\
\hline Spent fuel dwell & App. 5-13 years & App. 80 years & $\begin{array}{l}\text { Permanently or until potential } \\
\text { re-processing }\end{array}$ \\
\hline Location & $\begin{array}{l}\text { Pools of spent fuel in the } \\
\text { Dukovany and Temelin nuclear } \\
\text { power plants }\end{array}$ & $\begin{array}{l}\text { Storage in the Dukovany and } \\
\text { Temelin nuclear power plants, } \\
\text { backup repository Skalka }\end{array}$ & Deep geological repository \\
\hline Responsible & \multicolumn{2}{|c|}{ CEZ, a. s. } & SURAO \\
\hline Supervised by & \multicolumn{3}{|c|}{ State Office for Nuclear Safety } \\
\hline Financial means & \multicolumn{2}{|c|}{ Corresponding budget CEZ, a. s. } & $\begin{array}{l}\text { Nuclear account (CEZ, a. s. } \\
\text { contributions) }\end{array}$ \\
\hline
\end{tabular}

CEZ finances the deposition of spent fuel from its own budget, while the Radioactive Waste Repository Authority (SURAO) finances its activities from the nuclear account kept in the Czech National Bank, administered by the Ministry of Finance. The nuclear account is a financial account contributed to by all producers of radioactive waste in the amount laid down by Government Order No. 416/2002 Coll., which establishes the amount of the levy and the manner of its payment by the agents of radioactive waste to the nuclear account and the annual amount of the contribution for the municipalities and the rules for its granting. CEZ for example pays $50 \mathrm{CZK}$ for each $\mathrm{MWh}$ produced in nuclear power plants, while other producers of radioactive waste pay $30,694 \mathrm{CZK}$ for each barrel of 2001 , which is the basic depositing unit in repositories. In 2013, there was approximately 19 billion CZK on the nuclear account. Besides payments to the nuclear account, each operator of a nuclear facility in the Czech Republic runs an individual financial reserve for dismantling and remediation of that facility, as prescribed by The Atomic Act. ${ }^{143}$

The warrant of temporary depositing of spent fuel is, therefore, provided by CEZ until its delivery to the Radioactive Waste Repository Authority. Then the state takes over responsibility.

\subsection{The Regulatory and Safety Framework of the Nuclear Industry}

Unambiguously the key document for the Czech nuclear sector is the Act of January 24, 1997, on peaceful use of nuclear energy and ionizing radiations (The Atomic Act) and on amendments and alternations to some acts (see "Zákon ze dne 24. ledna 1997"), which has been amended already ten times, then Act No. 19/1997 Coll., Act No. 281/2002 Coll. as well as Act No. 44/1988 Coll. on the protection and utilization of mineral resources (The Mining Act) (see “Zákon č. 44/1988 Sb.”).

143 The annual reserve for the Dukovany nuclear power plant is set at 650 million CZK and 370.7 million CZK for the Temelin nuclear power plant (see Duda, 2002, p. 47). 
The Atomic Act regulates basically all aspects of not only the nuclear industry, but of ionizing radiation in general, which is, among other things, the regulation of the method of utilizing nuclear energy and ionizing radiation, and conditions for the performance of practices related to nuclear energy utilization and radiation activities, conditions for safe management of radioactive waste, performance of state administration and supervision within nuclear energy utilization, within radiation activities and over nuclear items, etc. The Atomic Act is very severe, as the strict limits which it has laid down induced problems during the construction of interim spent fuel storage on nuclear power plants sites. In May 2011, already the eleventh revision of The Atomic Act was discussed, which among other things introduced the possibility to provide compensations from the nuclear account also to communities whose cadastral area is subject to exploratory work related to a deep geological repository or in which such repository already existed.

The Mining Act, on the other hand, treats uranium mining and, as in the case of coal, it is the Czech Mining Authority and District Mining Authorities who watch over mining activity, observance of working conditions, the management of mining waste and supervise adherence to Acts Nos. 44/1988 Coll., 61/1988 Coll. and 157/2009 Coll. and other regulations (see Státní báňská správa České republiky).

Section 3 of The Atomic Act commissions the State Office for Nuclear Safety (SUJB) to perform the activities of public administration and supervision of nuclear energy and ionizing radiation use in the field of radioactive as well as in the field of nuclear, chemical and biological protection. The SUJB is the central organ of public administration subordinated to the Government, which makes the regulatory role in the field of nuclear industry held only by these two organs, the Government and the SUJB.

The SUJB implements the regulation process through decrees, addressing the fields of physical protection of nuclear materials and facilities; then the field of quality during activities related to nuclear energy use and activities leading to radiation, the field of criteria for facilities and the distribution of selected facilities across safety categories or criteria for placement of nuclear facilities or of sources of significant ionizing radiation. It, furthermore, treats the issue of radiation protection; emergency preparedness of nuclear facilities and workplaces exposed to sources of ionizing radiation. The SUJB is responsible for the functioning and organization of the National Radiation Monitoring Network. Organization of the National Radiation Monitoring Network as amended by Decree 27/2006 Coll. currently consists of 420 different monitoring points (early warning network, thermoluminescent dosimeter networks, air contamination monitoring points network), 12 laboratories and a range of mobile groups (see Státní ústav radiační ochrany, v. v. i.). 


\begin{tabular}{|c|c|}
\hline Organ & State Office for Nuclear Safety (SUJB) \\
\hline Headquarters & Prague, Senovazne namesti 9 \\
\hline Web & www.sujb.cz \\
\hline Role & $\begin{array}{l}\text { Its scope of authority, given by The Atomic Act No. 18/1997 Coll., Act No 19/1997 Coll. and by Act No. } \\
281 / 2002 \text { Coll., among others embraces the performance of state supervision of nuclear activities, nuclear } \\
\text { items, physical protection of nuclear facilities, radioactive protection and emergency preparedness in the } \\
\text { premises of a nuclear facility or of a workplace with sources of ionizing radiation; issuing authorizations } \\
\text { for activities governed by Act No. } 18 / 1997 \text { Coll., for example, to placing and operating a nuclear facility or } \\
\text { a workplace exposed to sources of high-level ionizing radiation, management of sources of ionizing radiation } \\
\text { and radioactive waste, transport of nuclear materials and radionuclide emitters; approving documentation } \\
\text { with reference to nuclear safety and radioactive protection set by The Atomic Act, to limits and terms of nu- } \\
\text { clear facilities' working process, means for assuring physical protection, emergency rules for transportation } \\
\text { of nuclear materials and particular radionuclide emitters, internal emergency plans of nuclear facilities and } \\
\text { workplaces exposed to sources of ionizing radiation; monitoring the level of radiation capturing residents } \\
\text { and workers operating with sources of ionizing radiation; a competent cooperation with the International } \\
\text { Atomic Energy Agency; coordination and security of activities while meeting the imperatives resulting from } \\
\text { Convention on the Prohibition of the Development, Production, Stockpiling and Use of Chemical Weapons } \\
\text { and on their Destruction within the meaning of Act No. 19/1997 Coll. and from the Convention on the Pro- } \\
\text { hibition of the Development, Production and Stockpiling of Bacteriological (Biological) and Toxin Weapons } \\
\text { and on their Destruction within the meaning of Act No. 281/2002 Coll., as well as the performance of the } \\
\text { function of the national authority according to The Comprehensive Nuclear Test Ban Treaty, from Conven- } \\
\text { tion on the Prohibition of the Development, Production, Stockpiling and Use of Chemical Weapons and on } \\
\text { their Destruction and Convention on the Prohibition of the Development, Production and. Stockpiling of } \\
\text { Bacteriological (Biological) and Toxin Weapons and on their Destruction. }\end{array}$ \\
\hline Organ & The National Institute for Nuclear, Chemical and Biological Protection (SUJCHBO) \\
\hline Headquarters & Milin, Kamenna 71 \\
\hline Web & www.sujchbo.cz \\
\hline Role & $\begin{array}{l}\text { The National Institute for Nuclear, Chemical and Biological Protection is the public research institution } \\
\text { founded by the State Office for Nuclear Safety on the basis of Act No. 281/2002 Coll. aimed at providing re- } \\
\text { search and development activities in the field of chemical, biological and radioactive substances and safety of } \\
\text { technical support of supervision and inspection activities performed by the Office in the areas of radioactive } \\
\text { protection and monitoring of the ban on the development, production, stockpiling and use of chemical and bi- } \\
\text { ological weapons. Research activity aims at identifying and quantifying radioactive, chemical and biological } \\
\text { materials, assessing their impact on people and the environment, including the assessment and development } \\
\text { of individual and collective means of human protection from these substances, decontamination and safety } \\
\text { research as part of the fight against terrorism as well as against severe industrial accidents. }\end{array}$ \\
\hline Organ & National Radiation Protection Institute (SURO) \\
\hline Headquarters & Prague, Bartoskova 28 \\
\hline Web & www.suro.cz \\
\hline Role & $\begin{array}{l}\text { The main subject of the Institute's activity is research into protection from ionizing radiation, including the } \\
\text { arrangement of the infrastructure of this research, specifically in the fields of safety research, research of the } \\
\text { Radiation Monitoring Network and research into exposure to artificial sources of ionizing radiation (nuclear } \\
\text { facilities, in the first place), research into medical exposure and research into exposure to natural sources of } \\
\text { radiation. Other activities include support to state supervision and monitoring of prevention, support to the } \\
\text { inspectors during their monitoring activities in the fields of radiation protection, emergency preparedness, } \\
\text { including departures and interventions, ensuring the laboratory activities for founders, performing the func- } \\
\text { tion of an analytical and conceptual workplace for analysis of impacts following nuclear and radioactive } \\
\text { accidents and preparing the drafting of measures, advisory and consulting services, education and public } \\
\text { enlightenment, etc. }\end{array}$ \\
\hline Organ & Radioactive Waste Repository Authority (SÚRAO) \\
\hline Headquarters & Prague, Dlazdena 6 \\
\hline Web & www.surao.cz, www.rawra.cz \\
\hline
\end{tabular}




\begin{tabular}{|l|l|}
\hline Role & $\begin{array}{l}\text { The Authority's major tasks and activities are the preparation, construction, operation initiation, operation } \\
\text { and shutdown of radioactive waste repositories and the monitoring of their environmental impact; ensuring } \\
\text { the processing of spent or radioactive nuclear fuel to a form adequate for depositing or further use; keeping } \\
\text { a record of received nuclear fuel and of its producers; managing levies of radioactive waste authors to the } \\
\text { nuclear account; preparation of proposals with reference to the establishment of payers' levies to the nuclear } \\
\text { account; management of radioactive waste which was brought to the Czech Republic from abroad and cannot } \\
\text { be returned, etc. Since 2000, it has been regulating all radioactive waste repositories in the Czech Republic: } \\
\text { Richard, Brotherhood, Dukovany and Hostim. It coordinates all work aiming at preparation and construction } \\
\text { of a deep geological repository of high-activity radioactive waste and spent nuclear fuel, the launch of which } \\
\text { is estimated in around 2065. }\end{array}$ \\
\hline $\begin{array}{l}\text { Sources: Zákon 458/2000; Zákon ze dne 24. ledna 1997; Státní úŕad pro jadernou bezpečnost.; Státní ústav radiační ochrany, } \\
\text { v. v. i.; Správa úložiš́t' radioaktivních odpadů; composed by T. Vlček. }\end{array}$
\end{tabular}

The SUJB is the founder of two public research institutes, namely the National Institute of Nuclear, Chemical and Biological Safety (SUJCHBO) and the National Radiation Protection Institute (SURO). Their role is not a regulatory one, but they have great importance in terms of protection against ionizing radiation. The Radioactive Waste Repository Authority (SURAO) has a similar protective role.

The important agents at the level of the supranational legal framework are the European Atomic Energy Community (EURATOM) and the United Nations mediated by the International Atomic Energy Agency (IAEA).

EURATOM was founded on March 25, 1957, in Rome and it has its headquarters in Brussels. Given that nuclear safety, naturally, represents one of the priority fields of EURATOM, this organ issues a vast number of directives and recommendations aimed at unifying the practice of radiation protection in all member states, whereas the directives cover this radiation protection in a comprehensive manner; from the basic principles and medical use of radioactive materials through to transport of radioactive substances. These directives were implemented in the Czech legal framework on the acquis communautaire basis either through The Atomic Act amendments or SUJB decrees.

The most complex legislative changes imposed from the outside took place as a result of the accession negotiations of the Czech Republic to the European Union, on which occasion a White Paper of the European Commission on Preparing the Associated Countries of Central and Eastern Europe for Integration into the Internal Market of the Union was adopted in 1995 (see Commission of the European Communities, 1995). A White Paper brought several important directives with reference to the nuclear energy field, which are the Directive on shipments of radioactive waste No. 92/3/EURATOM, supplemented by Directive No. 93/552/EURATOM (both were then altered by Directive No. 2006/117/EURATOM), Directive on basic safety standards No. 96/29/EURATOM, referring to maximum permissible doses of radioactive contamination of food arising after a radioactive emergency (accident), the import of agricultural products following the accident in Chernobyl or shipments of radioactive materials. Beside the White Paper, the Czech Republic also adopted a string of directives addressing the radioactive protection of the public, workers, patients as well as the information standard of residents.

The IAEA emerged on June 29, 1957, in Vienna, which is also its current location. The former Czechoslovakia was a member from the Agency's founding, while the Czech Republic joined on January 1, 1993. The Mission of the Agency is to enforce the safe and peaceful use of nuclear technologies. Unequivocally the key carrier of this mission is The Treaty on the Non-Proliferation of Nuclear Weapons, NPT), which entered into effect on March 5, 1970, and it was in 1995 prolonged for an indefinite period. With respect to energy safety, one of the goals of the Treaty is monitoring and cooperation during peaceful nuclear activities (see Závěšický, 2005, p. 132). IAEA is the exclusive monitor in the field of peaceful use 
of nuclear energy, resting on a unique monitoring mechanism based on the political will of states to make their nuclear facilities available to this monitoring. By doing this, a state demonstrates that it has fulfilled its obligation resulting from the Non-Proliferation Treaty and its additional protocols.

By its mandate given by the Articles of Association/Statute, the IAEA is obliged to promote the peaceful use of nuclear energy and to control whether secret abuse for military purposes does not take place. A special type of inspector was established for this monitoring function, which on the basis of bilateral agreements of member states with EURATOM, Safeguard Agreements, execute regular inspections of all declared nuclear facilities in the countries not possessing nuclear weapons and non-military facilities in countries which do possess the weapons (see "Stálá mise," 2010). Until 2009 the initial agreement between IAEA and Czechoslovakia from March 1972 was in charge, while the Czech Republic on October 1, 2009 approached a Trilateral Safeguard Agreement (INFCIRC/193 or also 78/164/EURATOM). The Czech Republic, therefore, accepted the commitment to approach trilateral agreements between EU member states not possessing nuclear weapons, EURATOM and IAEA as part of the IAEA safeguard system (see SÚJB, n.d.a). Based on the Trilateral Safeguard Agreement and within the meaning of Commission Decree No. 302/2005/EURATOM from February 8, 2005, on implementation of EURATOM safeguards, starting from 2005, inspections of nuclear facilities are performed by both IAEA and EURATOM inspectors.

When speaking of supranational regulation, the European Nuclear Safety Regulators Group, (ENSREG) should not be understated, as an independent body initiated in 2007 resulting from a Decision of the European Commission. The ENSREG consists both of EU members and officials from national nuclear safety offices, radioactive waste management offices and radioactive protection offices of all EU member states. The ENSREG's goal is reaching mutual understanding and development in the fields of nuclear safety and management of radioactive waste (see The European Nuclear Safety Regulators Group).

\subsection{Demand Forecast}

According to forecasts, power use will increase in the Czech Republic, while the country is accordingly limited by the current setting of the energy mix with a predominant share of the coal sector. Table 6.6 displays a comparison of goals declared in the State Energy Concept and its revisions with reference to consumption of energy sources by 2050. It is evident that the role of the nuclear sector in the Czech power industry will most likely improve to make up a third of all energy sources in the Czech Republic. In terms of installed capacity of nuclear power plants, scenarios also count on the increased capacity of existing blocks, whereas the actual installed capacity of nuclear power plants was 4,404 MWe as of December 31, 2012 (see table No. 6.1), and in the case of Temelin's completion, installed capacity will by 2030 be approximately 6,440 MWe (excluding the potential construction of the new block in the Dukovany power plant). 


\begin{tabular}{|c|c|c|c|c|c|c|c|c|}
\hline \multicolumn{9}{|c|}{$\begin{array}{l}\text { Tab. 6.6: The Shares of Solid, Liquid and Gas Fuels in Energy Resource Consumption According } \\
\text { to the State Energy Policy of the Czech Republic from } 2004 \text { and Its Revisions from } \\
\text { February } 2010 \text { and August } 2012 \text { (in \%) }\end{array}$} \\
\hline Type of Fuel & $\begin{array}{c}\text { Level in } \\
2000\end{array}$ & $\begin{array}{c}\text { Level in } \\
2005\end{array}$ & $\begin{array}{c}\text { Level in } \\
2008\end{array}$ & $\begin{array}{l}\text { Long-Term } \\
\text { Goal (SEP } \\
\text { 2004) by } 2030\end{array}$ & $\begin{array}{l}\text { "Green" } \\
\text { Scenario } \\
\text { (SEP 2004) } \\
\text { year 2030 }\end{array}$ & $\begin{array}{l}\text { Revised SEP } \\
(2 / 2010) \\
\text { Scenario by } \\
\quad 2030\end{array}$ & $\begin{array}{l}\text { Revised SEP } \\
\text { Scenario } \\
(2 / 2010) \text { by } \\
\quad 2050\end{array}$ & $\begin{array}{c}\text { Revised } \\
\text { SEP } \\
\text { (8/2012) } \\
\text { Target } \\
\text { Values by } \\
2040\end{array}$ \\
\hline Solid & 52.4 & 42.5 & 45.3 & $30-32$ & 30.5 & 24 & 20 & $12-17$ \\
\hline Gas & 18.9 & 21.6 & 15.7 & $20-22$ & 20.6 & 20 & 21 & $20-25$ \\
\hline Liquid & 18.6 & 15.7 & 20.9 & $11-12$ & 11.9 & 20 & 19 & $14-17$ \\
\hline Nuclear & 8.9 & 16.5 & 15.3 & $20-22$ & 20.9 & 25 & 25 & 30-35 \\
\hline Renewables & 2.6 & 5.4 & 2.9 & $15-16$ & 15.7 & 11 & 15 & $17-22$ \\
\hline
\end{tabular}

Source: Státní energetická koncepce, 2004, p. 11-12, 40-49; Ministerstvo průmyslu a obchodu, 2010a, p. 77-92; Český statistický úřad, 2008; Ministerstvo průmyslu a obchodu, 2012, p. 20-21.

According to the 2/2010 Revision, the mining of uranium should be "supported should it provide full compliance with the requirements of nature and landscape protection, applications for exploration areas should not be blocked, while mining should from now on be run by a state company. Continuation of uranium mining should be ensured by opening a new deposit already during the active operation of the Rozna Mine, in order not to lose the valuable know-how of the Czech uranium industry, whereas reversing the declining trend of the domestic production of uranium concentrate is also a requirement" (see MPO, 2010a, p. 31, 40). Revision even mentions the possibility to "support the potential construction of uranium concentrate processing plants in the Czech Republic with regard to enhancing energy security of the country (and for production for the Central European market) and screen the potential construction of the spent fuel processing plants" (see MPO, 2010a, p. 31).

The Government has several times declared its clear stance on the development of the nuclear sector (and completion of the Temelin nuclear power plant), while the Prime Minister, Petr Necas, declared at the $11^{\text {th }}$ Energy Congress of the Czech Republic that the Czech Republic "intends to continue to run the Temelin and Dukovany nuclear power plants and to continue the process that will lead to the construction of additional nuclear units" (see Nečas, 2011, p. 199). The Dukovany nuclear power plant also has a much greater potential, as there is, according to its chairman, Tomas Zak, "producing potential at the site of Dukovany, given by the exterior conditions, around 3,000 to 3,500 MW by applying existing technologies, while there are more possibilities than that" (see Cieslar, 2010e).

Confidence in nuclear energy and interest in its development and completion is in a relatively stable manner demonstrated by the Chamber of Deputies. In May 2008, 190 deputies voted for completion of the Temelin nuclear power plant, in June 2010, it was 186 of them, and in April 2011, it was 181 out of a total of 200 deputies who supported this project (see Pravec, 2011, p. 44-45). As of the latter, the decision of the remaining four deputies was associated with events related to the Japanese Fukushima Daiichi nuclear power plant.

In 1980, Ludvik Kopacka wrote that "nuclear energy is truly becoming a developing energy source in the Czechoslovak context, which will gradually assume the role of covering increasing energy demand and gradually the increasing consumption of primary sources as well" (see Kopačka, 1980, p. 214-215). This idea basically remains applicable even in the second decade of the third millennium. The Paces Commission argues that "in the course of around 2020-2030, the lifespan of the existing nuclear power plants 
should be prolonged for at least 60 years, while the increase in energy consumption in the Czech Republic and the replacement of gradually closing coal-fired power plants in terms of their basic capacity should be covered by building new nuclear power plants, reaching the share in power production today already existing in France, for example (77 \%)", and "in the course of around 2040-2050, to initiate the construction of fast reactors" (see ÚVČR\&NEK, 2008, p. 108-109).

Based on this information, it is rather evident that the Czech Republic has a firm position regarding the development of nuclear industry, that this sector is not indifferent to it and that it has a very important potential for energy and supply safety of the Czech Republic and that the Czech Republic counts on the increasing use of this sort of energy both in the short and long term. We can say that state energy policies as well as the State Energy Concepts and their revisions support the development of the nuclear industry, while the intensity of this support grows with every new legislative or conceptual document. Table No. 6.9. clearly displays the increasing interest in nuclear energy, where every new document affords it a gradually broader share in primary sources consumption, specifically from $20 \%$ in the 2004 State Energy Concept up to $35 \%$ in the revised version of State Energy Policy (8/2012).

Unlike coal and natural gas, there is no legal obligation to keep reserves of uranium (OECD Nuclear Energy Agency / IEAE, 2008, p. 171), not even resulting from the membership in IAEA or EURATOM. One of many objectives declared in the so far applicable 2004 State Energy Concept is the generation of "nuclear fuel strategic reserves in a form adequate for filling up the reactor" (see "SEK", 2004, p. 27), which is, however, not binding. With regard to the high density of nuclear power plant fuel, the relative stability of its price and the vast number of active producers of uranium concentrate as well as the substantial number of processing institutions, it is possible to stock up for a decade in advance. The Revision of the State Energy Concept from February 2010, however, includes a reference to considering the possibility "to create strategic reserves of uranium concentrate relative to the increasing share of production in nuclear power plants and development of mining" (see MPO, 2010a, p. 29). Based on the following tables, it is evident that such thinking is definitely substantiated.

\begin{tabular}{|c|c|c|c|c|c|c|c|}
\hline \multicolumn{6}{|c|}{ Tab. 6.7: Forecast of Uranium Concentrate Production in the Czech Republic (tonnes per year) } \\
\hline $\mathbf{2 0 0 5}$ (level) & $\mathbf{2 0 0 7}$ (level) & $\mathbf{2 0 0 9}$ (level) & $\mathbf{2 0 1 0}$ & $\mathbf{2 0 1 5}$ & $\mathbf{2 0 2 0}$ & $\mathbf{2 0 2 5}$ & $\mathbf{2 0 3 0}$ \\
\hline 409 & 291 & 243 & 200 & 50 & 50 & 40 & 30 \\
\hline
\end{tabular}

Source: OECD Nuclear Energy Agency, 2009, p. 42-43; Ministerstvo životního prostředí / Česká geologická služba - Geofond, 2010, p. 199; modified by T. Vlček.

Tab. 6.8: Forecast of Uranium Concentrate Demand in the Czech Republic (tonnes per year)

\begin{tabular}{|c|c|c|c|c|c|c|}
\hline $\mathbf{2 0 0 7}$ (level) & $\mathbf{2 0 1 0}$ & $\mathbf{2 0 1 5}$ & $\mathbf{2 0 2 0}$ & $\mathbf{2 0 2 5}$ & $\mathbf{2 0 3 0}$ & $\mathbf{2 0 3 5}$ \\
\hline 772 & $860-870$ & $670-680$ & $675-880$ & $830-1000$ & $830-1000$ & $830-1000$ \\
\hline
\end{tabular}


Revision of the State Energy Concept (2/2010) intended to ensure energy security of the country by setting a legal framework which would oblige nuclear power plant operators to keep reserves of nuclear fuels (fuel rods) $)^{144}$. The period of maximum use of a specific nuclear power plant, which obligatory reserves will be requested for, should be set so as to, in case of a supplier's delivery failure (failure to meet commitments resulting from agreement or impossibility of their enforcement) realistically ensure the provision of a supplementary supplier without jeopardizing the operating process, while considering the development of conversion and processing capacities, supplier's experiences and competition in the world market (see MPO, 2010a, p. 73). This idea also persisted in the Revised State Energy Policy 8/2012, where one of the strategies for increasing energy security and resilience of the Czech Republic was the "keeping of reserves of fuel rods by nuclear power plant operators, warranting facilities' full operating capacity for three years, potentially also by means of reserve contracts on reserving capacity for fuel supplies or by keeping corresponding reserves of enriched uranium and processing fuel on their own within the territory of the Czech Republic" (see MPO, 2012, p. 27).

\subsection{Completion of the Temelin Nuclear Power Plant}

On August 3, 2009, CEZ released the announcement about opening a call to tender for two new nuclear blocks for the Temelin nuclear power plant. To some extent it was based on the investment plan for the construction of the Temelin power plant with 4 x 1,000 MWe of installed capacity, adopted in February 1979 , replicating the construction site itself and some already existing auxiliary systems. Some options which were exclusively in CEZ's interest were originally also a part of the tender, specifically to build three additional nuclear blocks in other potential localities in Europe. (see ČEZ, a. s., 2009a) Currently CEZ, however, does not count on these options and is preparing a separate tender for building the fifth block in Dukovany, which was one of these options. Although it is still not specified where, it will most likely involve the fifth block in Dukovany and two blocks in Slovak Jaslovicke Bohunice. Total capacity of the new nuclear plant has not been finally specified so far, while the propositions embraced the variants $2 \times 1,200$ MWe or $2 \times 1,700 \mathrm{MWe}$ (see Vnouček \& Kasembe, 2000, p. II-III). Following the elimination of AREVA SA from the tender, only $2 \times 1,200$ MWe remained as an option. It is not just the project that is part of the tender, but the construction works itself, which makes the entire endeavour, therefore, a turnkey power plant.

After it is awarded, the overall administrative tender process will last for roughly 7 to 8 years (together with the construction, 15 years), which means that the connection of new blocks is estimated for around 2024. The tender's finale and the signing of the contract by its winner was set at the end of 2011, in October 2010 it was, however, decided that selecting the construction works' supplier must be postponed until 2013 due to the unpreparedness of suppliers, which will naturally lead to a delay in the entire process. According to recent updates, construction is meant to last for 12 years from the day of the tender's awarding. Should the tender truly be awarded in 2013, the power plant would emerge in 2025 (see Zelenka, 2011, p. 28). The deadlines are, however, impossible to meet without altering the applicable construction and permit legislation. The role of the Government's Commissioner for the CEZ, a. s. nuclear tender was given to Vaclav Bartuska, Special Envoy for Energy Security of the Czech Republic.

144 These reserves should be covered by an operator. 
Three entities applied to the tender. It was a Consortium of the companies SKODA JS, a. s., from the Czech Republic, Atomstrojexport, a. s., from the Russian Federation (a daughter company of the Russian company ZAO Atomstrojexport ${ }^{145}$ ) and OKB Gidropress, a. s. ${ }^{146}$ from the Russian Federation, offering the project MIR 1200 (Modernized International Reactor) with 1,198 MWe of capacity ${ }^{147}$. The French company Areva SA ${ }^{148}$ offered the EPR ${ }^{\mathrm{TM}}$ (European Pressurized Reactor) with 1,700 MWe of capacity ${ }^{149}$ and finally, the American Company Westinghouse Electric Company, LLC ${ }^{150}$, offering the project AP1000 with 1,200 MWe of capacity. All cases refer to the reactors of the III, III+ generation.

\begin{tabular}{|l|c|c|c|}
\hline Tab. 6.9: Technical Characteristics of the Projects Proposed by Single Nuclear Tender Applicants \\
\hline Company & $\begin{array}{c}\text { Westinghouse Electric } \\
\text { Company, LLC }\end{array}$ & Areva SA & $\begin{array}{c}\text { SKODA JS, a. s., Atom- } \\
\text { strojexport, a. s., OKB } \\
\text { Gidropress, a. s. }\end{array}$ \\
\hline Project & AP1000 & MIR 1200 (AES 2006) \\
\hline Thermal capacity(MWt) & 3,415 & 4,590 & 3,200 \\
\hline $\begin{array}{l}\text { Electrical capacity (MWe, net } \\
\text { /gross) }\end{array}$ & $1,117 / 1,200$ & $1,590 / 1,700$ & $1,113 / 1,198$ \\
\hline Efficiency ( \%) & 33 & 36 & 33.7 \\
\hline Capacity factor (\%) & 93 & 90.3 & $>98 *$ \\
\hline $\begin{array}{l}\text { Number of cassettes in the ac- } \\
\text { tive zone }\end{array}$ & 157 & 241 & 163 \\
\hline Number of rods in cassettes & 264 & 265 & 312 \\
\hline Number of steam generators & 2 & 4 & 4 \\
\hline $\begin{array}{l}\text { * Such a high value results from shorter maintenance and refuelling breaks and prolonged fuel campaigns. } \\
\text { Source: Bílý, 2011, p. 268; Company's official documents; selected and modified by T. Vlček. }\end{array}$ \\
\hline
\end{tabular}

145 ЗАО Атомстройэкспорт is the leading Russian organization building nuclear power plants abroad and accordingly engaged in their modernization. It is supervised by the Federal Agency for Nuclear Energy, Rosatom (Федеральное агентство по атомной энергии России, РосАтом). A larger part of the shares (50.2\%) of ZAO Atomstrojexport belongs to the companies VPO Zarubežatomenergostroj (44\%; Всероссийское производственное объединение “Зарубежатомэнергострой”) and OAO TVEL (6.2\%; ОАО “ТВЭЛ”), which Rosatom controls on behalf of the state, and $49.8 \%$ Gazprombance (ОАО “Газпромбанк").

146 A daughter company of the Russian company OAO OKB Gidropress (ОАО ОКБ “Гидропресc").

147 Based on talks with the Russian side, it is interesting that the tender should have included a seriously intended offer to build a manufacturing plant in the Czech Republic, i.e. a plant for assembling fuel cassettes out of single pallets. According to the Russian calculation, that sort of plant proves profitable for the state if there are at least eight reactors, which is the number the Temelin power plant will reach after completion. This is accordingly an opportunity for fuel fabrication for the Russian type of power plant in Slovakia and elsewhere. The paradox is that in this manner the most frequent comment on the Russian project, i.e. intensification of Czech energy dependence on Russia, to some extent ceases to be logical.

148 The ownership structure is as follows: $73.03 \%$ Commissariat à l'énergie atomique (technological research institution financed by the French Government); 10.17 \% French state; $4.82 \%$ Korean car industry Kia Motors and the remaining $11.98 \%$ other companies, employees and publicly traded stocks.

149 The great advantage of this reactor may be found in the high rate of capacity maneuverability.

150 Belonging to the Japanese companies Toshiba Corporation (67\%) and Ishikawajima-Harima Heavy Industries Co. Ltd. (3\%), American mechanical companies The Shaw Group (20\%) and Kazakh state company Kazatomprom NAC (Казатомпром НАK $10 \%$ ). 
On October 5, 2012, CEZ announced the elimination of the French company Areva from the competition for building new blocks in the Temelin nuclear power plant, because it did not meet the basic commercial and legal terms of the competition (see "ČEZ vyřadil AREVU"). Areva submitted an appeal to the Czech Office for the Protection of Competition, which in February 2013, however, found the elimination substantiated. The company intends appeal to the Chairman of the Office, potentially also to forward the matter to the Czech courts.

In the first round of the tender, the subjects of evaluation were, for example, technology, price and safety. According to the results from March 2013, the American company Westinghouse Electric Company, LLC, was the first in this aspect, but the lowest price was, however, offered by the Russian-Czech consortium. CEZ is currently working on improving its negotiating position in relation to the tender applicants and also on deciding if the construction will take place in the first place. The AP1000 reactor is in many aspects a revolutionary one, with an advantage drawing from its modular construction, which, on the other hand, poses a problem in terms that it has not been tried before and that it could, therefore, potentially limit the inclusion of domestic companies in the project. MIR is an evolutionary reactor based on the long history of VVER reactors as well as on Russian experience with breakdowns. It is a tested and cheaper reactor, but, on the other hand, the technologically older one.

Although CEZ argues that the construction of new nuclear blocks arises from the applicable State Energy Concept, Policy of Spatial Development and the conclusion of the Paces energy commission (see ČEZ, a. s., 2009a), the company has been criticized for its poor communication with the majority stakeholder during the tender's preparation ${ }^{151}$. It is the greatest tender in the world and, according to Deputy Minister of Industry and Trade, Tomas Huner, the state will have its own part in it so to ensure full control over it: "The state has very strong options. It can change the Statute and it can directly express its opinion regarding the tender, bypassing the General Meeting of Stakeholders, where $70 \%$ of shares are owned by CEZ. It also has the bluntest tool in its hands, that is the ability to even replace the management" (see Rafaelová, 2009).

In terms of the nuclear sector, the Government's policy statement is clear. It expresses the state's will to support both the construction of new blocks in the Temelin nuclear power plant and modernization of the Dukovany nuclear power plant, including the accompanying range of buildings so as to achieve a balanced energy mix. The state will, furthermore, proceed with its transparent approach while searching for sites for radioactive waste repositories, including support for other options leading to their decommissioning (see VČR, 2010a, p. 37). The Government, with respect to the development of the nuclear industry, is behaving in a very coherent and conceptual manner, arising from state energy policies as well as from State Energy Concept and its so far unapproved revision.

When the Expert Working Group for Energy Security in 2006 submitted its conclusions regarding Czech energy to the Committee for the Foreign Security Policy Coordination, it recommended prolonging the lifespan of the Dukovany and Temelin nuclear power plants, for the state to create the conditions for further quantitative and qualitative development of the nuclear sector and to seek to increase electricity production through the framework of the existing localities - in other words, to complete the Temelin nuclear power plant and, in the further perspective, also the facilities in the originally planned localities (Blahutovice ${ }^{152}$ ), whereas it is for diversification reasons recommended to have the new technologies supplied

151 The state, however, was informed, although probably indirectly. Already in July 2008, CEZ asked the Ministry of the Environment to assess the environmental impact of the intended completion of the Temelin nuclear power plant.

152 General Director of CEZ, Martin Roman, in May 2011 indicated the possibility of building a nuclear power plant in Blahutovice as "the very distant future", which would get its turn only after completion of the Temelin and Dukovany power plants, therefore not before 2040 (see “Otázky Václava Moravce”, 2009). 
from EU countries (see Odborná pracovní skupina pro energetickou bezpečnost [OPSpEB], 2006, p. 14). The document also recommends "the restoration of uranium mining, because for the major construction of nuclear sources in the Russian Federation and, in parallel, unchanging capacity of nuclear fuel production, there could be a shortage of that fuel. A country capable of supplying its own uranium and asking only for its processing into fuel will be unambiguously at an advantage in comparison to those who asking for the complete purchasing of fuel" (see OPSpEB, 2006, p. 8-9). The discussed revision of The Atomic Act also advocates the development of uranium mining, which should enable the allocation of funds from the nuclear account also to municipalities subject to mining exploration related to a deep geological repository, which could be a good way to reach a consensus between the state's and municipalities' interests while searching for a proper locality for building this deep geological repository.

"Preparation of and proceeding with a schedule of a supplier selection process for the completion of Temelin nuclear power plant has been approved, and I hereby wish to confirm that this plan has stayed unchanged. The Government wishes and, through the means of its share in CEZ will achieve having a winner known by the end of 2013", are the words of Prime Minister, Petr Necas, at the $11^{\text {th }}$ Energy Congress of the Czech Republic (see Nečas, 2011, p. 199-200). CEZ has been preparing very seriously for the Temelin project. Among these, on April 1, 2009, a new division, Construction of Nuclear Power Plants, emerged, coordinating the preparation of nuclear projects not only within the Czech Republic (Temelin and Dukovany), but also abroad (Jaslovske Bohunice - Slovakia) (see ČEZ, a. s., 2010b, p. 5). The inclination of the Czech residents to the nuclear sector is not just a relic of an open attitude towards heavy mechanical industry and a centralized power industry in past years, but also the success of CEZ's public relations policy.

Large coal power plants in the Czech Republic, Poland and Germany will be gradually shut down in forthcoming years due to age (after 2020, this is the scenario awaiting all Czech coal-fired power plants, aside from the new Ledvice and modernized Tusmice and Prunerov), the Czech Republic presently has difficulties with building any larger blocks (only the Pocerady combined cycle power plant and Ledvice power plant are in the building process), problems with integration of renewables are forcing the state to search for strong investments into regulatory energy and regulatory management, the political decision to depart from nuclear energy in Germany ${ }^{153}$, all of these pose a serious threat of a power shortage from 2015 approximately to the period of expected completion of Temelin (while the situation on the market has already confirmed this threat following the disconnection of the German nuclear power plants after the incident in Fukushima). These circumstances, therefore, partially play into hands of the Temelin's completion with nuclear blocks with 2 x 1,700 MWe of installed capacity, regardless of substantially larger investments necessary for the transmission system than in the case of other two offers. ${ }^{154}$

Former Minister of Industry and Trade, Martin Kocourek, however, points to a particular deceleration of nuclear energy development tied to the accident in the Fukushima Daiichi nuclear power plant. "The security of these devices will be, without doubt, discussed in a comprehensive and rational manner, while the engineers will have to invent better ways of handling operation under emergency conditions" (see Kocourek, 2011, p. 11). This event together with the opposition of some organizations in the Czech Republic

153 After the accident in Fukushima Daiichi, Germany immediately suspended the operation of its eight older nuclear power plants, while the expert commission assessing their re-launch in May 2011 recommended leaving them closed. The Ethics Commission then decided to shut down all nuclear power plants by 2021, resp. 2022. The departure from the nuclear industry is not new for Germany, as it had six nuclear reactors closed within the territory of German Democratic Republic immediately after the unification of Germany in 1990, while the construction of five reactors already in the building process (Stendal nuclear power plant) was postponed and then entirely terminated a year after. 
will represent the greatest limit of nuclear sector development from now on. ${ }^{155}$

The strongest protest against the completion of the Temelin nuclear power plant comes from the organizations DUHA Movement, South Bohemian Mothers, Greenpeace, Calla - Association for Preservation of the Environment, Citizens' Initiative for Environmental Protection, Green Circle and the above-mentioned Green Party. The idea common to all these organizations can be summed by the words of Martin Sedlak from the DUHA Movement: "The Czech Republic will make do without additional reactors. Green sources in combination with the enormous potential of increased efficiency can ensure enough energy for Czech households and industry. The new nuclear power plant looks like a mere footnote in comparison to these clean solutions. They, moreover, have an indisputable advantage as the costs of renewables decline and in the course of ten years they will be stepping on atom's toes" (see Jihočeské matky, 2011).

The DUHA movement also highlights the incapacity of some tender applicants to meet set deadlines, with a pretext of ongoing projects world-wide (see Polanecký \& Sedlák, 2010). Their arguments should definitely be taken into consideration, as one of the pressing issues which organizations are warning about is the limited liability of the operator running the nuclear power plants across the Czech Republic for nuclear damage. "Should a serious accident occur in Temelin, all affected would together receive only six billion CZK. CEZ would in that case, paradoxically, receive 35 billion CZK from the insurance companies," says Martin Sedlak (see Sedlák, 2009, p. 31). According to environmental organizations, CEZ must take a full financial responsibility for nuclear damage, because the current limit of 8 billion CZK is insufficient and does not even correspond to the adopted international conventions (see Jihočeské matky, 2011).

\begin{tabular}{|c|c|c|}
\hline \multicolumn{3}{|c|}{$\begin{array}{l}\text { Tab. 6.10: Comparison of Some Economic and Environmental Advantages and Disadvantages of } \\
\text { Nuclear and Thermal Power Plants }\end{array}$} \\
\hline Subject of Comparison & Nuclear Power Plant & Thermal Power Plant \\
\hline Fly ash emissions & No & Only coal power plants \\
\hline $\mathrm{SO}_{2}$ and $\mathrm{NO}_{x}$ emissions & No & Yes \\
\hline Operational spillage of radioactive materials & Yes (small amount) & Yes (small amount) \\
\hline Ratio of produced energy per mass unit of fuel & $2,100 \mathrm{GJ} / \mathrm{kg}$ & $0.033 \mathrm{GJ} / \mathrm{kg}$ \\
\hline Costs of fuel transport & Low & High \\
\hline Exhaustibility of fuel sources & $\begin{array}{c}\begin{array}{l}\text { Yes (later than in the case of fossil } \\
\text { fuels) }\end{array} \\
\end{array}$ & Yes \\
\hline Amount of "ash" resp. of spent fuel & Small & Great \\
\hline Costs of spent fuel liquidation & $\begin{array}{l}\text { High (mainly resulting from the } \\
\text { dangerousness and necessity of } \\
\text { the long term deposition) }\end{array}$ & $\begin{array}{l}\text { High (mainly resulting from great- } \\
\text { er volume) }\end{array}$ \\
\hline Risk of a big accident & Small & Great \\
\hline Consequences in case of big accident & Great & Small \\
\hline
\end{tabular}

The safety of nuclear power plants is also subject to criticism, and especially in terms of spent nuclear fuel. Table 6.10 clearly illustrates that nuclear power plants are during regular operation much less risky than the thermal ones under conditions of notable energy density. In the event of a great accident, a nuclear

155 On the other hand, the accident in Fukushima Daiichi means work for Czech nuclear physicists as the escalation of monitoring and various tests of existing nuclear power plants will most probably become an interesting business, which the Institute of Nuclear Research in Rez is preparing for at the level of the Czech Republic (for more details see Korbel \& Kostka, 2011, p. 30). 
power plant is, nonetheless, unequivocally the most risky type of power plant and the criticism is here substantiated. The State Office for Nuclear Safety regularly and strictly monitors the existing nuclear power plants ${ }^{156}$, while testing of both nuclear power plants was scheduled for 2011 even prior to the accident in the Japanese power plant.

As a result of the Fukushima Daiichi accident, in 2011 stress tests were carried out. These tests were done in three parts. The first was implemented on individual nuclear plant operators (i.e. CEZ), the other was executed by national regulators (SUJB) and the third involved the monitoring of inspectors from other countries (European Nuclear Safety Regulators Group ${ }^{157}$, hence the European Commission) (see Macková, 2011; SÚJB, n.d.b). This plan was presented and confirmed in April 2011 in Vienna at the Convention on Nuclear Safety Fifth Review Meeting.

At the European Nuclear Energy Forum in May 2011 in Prague, Special Envoy for Energy Security the Czech Republic, Vaclav Varuska, said "European nuclear power plants should not undergo uniform stress tests, because there are different types of reactor in Europe and likewise unified tests cannot be implemented on, for example, motor bikes, cars and cargo vehicles" (see Egger \& Schweiger, 2011). The Austrian association Atomstopp oberoesterreich immediately reacted with strong criticism of Czech nuclear plants' safety ${ }^{158}$ (see Egger \& Schweiger, 2011). The Czech Republic has in reality, however, executed the stress tests alone (like France, for example), while their form was delineated by the Ministry of Industry and Trade together with the SUJB. Preparatory work started already in April and the nuclear power plant operator had time to implement them by the end of September. In addition to the impact of natural disasters (for example, a tsunami or earthquake ${ }^{159}$ ), the possible effects of extremely high or low temperatures was tested as well (see ČTK, 2011). If the European Union orders the execution of further tests, they would be implemented additionally.

The final report following the process of mutual evaluation of nuclear plants' resistance by the members of the EU27 both for Temelin and Dukovany power plants was as follows: "No conditions were identified that would require an immediate solution. The power plant is able to safely manage even highly improbable extreme emergency conditions without posing any threat to its vicinity" (see ČEZ, a.s., 2011a; ČEZ, a.s., 2011b).

Although the completion of the Temelin nuclear power plant and further development of the nuclear sector in the Czech Republic is a priority and a conceptual matter for the Czech Government, these goals, however, remain so far uncertain. Aside from the abovementioned problems, the situation is not getting any better also due to the financial insufficiency of the main investor, CEZ, resulting from problematic investments it made in the Balkans in recent years. Martin Roman, former General Director of CEZ however justifies these investments by arguing that it was both a little above a fifth of overall CEZ investments and, accordingly, that foreign investments in the amount of 70 billion CZK have already in the last five years generated a cumulative profit of approximately 40 billion CZK. Investments are allegedly returning faster than expected (see “Otázky Václava Moravce”, 2011).

156 In relation to the character of the accident in Fukushima, it should be added that each Czech block has backup sources of power in the amount of three separate diesel aggregates, which are furthermore secured with batteries.

157 European Nuclear Safety Regulators Group, ENSREG.

158 With regard to the Austrian reaction, we should turn to Vaclav Baran who concludes that antinuclear movements are primarily an ideology in Austria, having little to do with rationality and which "safely know how to free the world from threats" (see Baran, 2002, p. 36). On this basis we can conclude that the Czech Republic will probably never satisfy Austrian criticism, regardless of a vast number of talks and agreements closed.

159 Seismic resistance of nuclear facilities in Czechoslovakia was set by the state standard at five on the Richter scale (see Blažek, 2009, p. 60). 
CEZ is still at any rate looking for options of how to ensure good conditions for such a high investment. One of the variants is a permanent guarantee of purchase prices from new Temelin blocks provided by the state or a guarantee of the investment's return. According to the latest information, the Ministry of Industry and Trade headed by Martin Kuba disagrees with both options and proposes a short-term system which would provide CEZ with state support in case the market prices go lower than the prices agreed, and, in the opposite case, expect the company to allocate the surplus to the state (see "Kuba je proti trvalé"). We should, therefore, expect long and complicated discussions, where the position of the players involved will change many times.

According to Ladislav Blazek, Former Development Deputy of the Federal Ministry of Energy and one of the leading Czech experts in the field of mechanical mine installations, energy and gasworks, the prospects of this sector are entirely evident. "Without developing the nuclear industry, the Czech Republic can only barely make do, if it wishes to achieve energy independence, complete its commitments of emissions reduction and if it does not wish to waste the experience which was gained. No responsible politician can deny the need to construct additional sources of nuclear energy in the shortest period possible, if he or she does not wish to speculatively lower the hard won energy self-sufficiency of the Czech Republic" (see Blažek, 2009, p. 68). 



\section{Chapter 7: Renewables}

Tomáš Vlček

\subsection{Introduction}

"Renewable natural sources have the ability, when gradually consumed, to be restored partially or completely by themselves or with man's contribution. Non-renewable natural sources perish with consumption" (viz "Zákon č. 17/1992 Sb."). This is the definition of renewables as amended by the Czech environmental legal framework. ${ }^{160}$

The renewable energy sector is by far the oldest in the world as its history dates back to the Stone Age, when men initially started to combust biomass to heat and light the space they lived in. On the other hand, it is (except for hydropower plants) a young, relatively new sector, with, perhaps, the greatest pace of development, reacting to the world trend of fighting climate change, protection of the environment, reduction of harmful greenhouse gas emissions and increasing energy self-sufficiency by limiting the import of energy materials. Although the research, development and increasing use of renewables had been recorded throughout the twentieth century, not before the 1990s did the renewables sector start its real development.

Activities related to climate change and environmental protection issues can be seen as the primary reasons for a massive development of the renewables sector. The development has been underway since the 1990s, which in terms of time corresponds to the above-mentioned key activities. Issues related to a lack of fossil fuels and projections that a hydrocarbon era would see its end by the $21^{\text {st }}$ century (coal, oil and natural gas depletion) also played a role. The terms for renewables development are de facto determined and to the greatest measure affected by the United Nations and, eventually, by the European Union. The basic terms set by these organizations are then addressed by single states, energy sectors and private entities.

In the renewable energy sector, we can generally distinguish two policies, namely a low carbon policy and a renewable energy policy. A low carbon policy does not a priori reject different and fossil energy sources, but it, on the contrary, tends to adjust the present power industry to the low carbon principle as closely as possible, that is to achieve minimum production of $\mathrm{CO}_{2}$ as the main greenhouse gas. This policy does not exclude (even advocates) the use and development of nuclear energy as an emission-free source. ${ }^{161}$ Renewable sources of energy can be at different levels of importance, but they are always more or less complementary in relation to primary sources. A perfect example of this policy is the policy of France. The policy on renewable sources of energy highlights precisely the word "renewable" and, basically, takes any fossil fuels out of further consideration. A complete shift to renewables appears as an evident interest indicated by this policy, while the existing obstacles emerge in the form of the everlasting nature of human knowledge and technology, technical aspects and finances. The policy on renewables is demonstrated by the Federal Republic of Germany.

160 Act No. 165/2012 Coll. on promoting energy sources delineates it in more detail by understanding renewable sources as renewable non-fossil natural sources of energy, namely wind, solar energy, geothermal energy, water energy, soil energy, air energy, biomass energy, landfill gas energy, sludge gas energy from wastewater treatment and biogas energy (see The Act of January 31, 2012).

161 Meant in the field of evaluated types of emission, excluding water steam which is, naturally, the most extensive greenhouse gas. 
The Czech Republic propagates a low carbon policy in an unambiguous manner, primarily for economic reasons.

According to the definition in the Czech legal framework (in Act No. 180/2005 Coll. on Promotion of the Use of Renewable Sources), "renewable sources are understood as renewable non-fossil natural sources of energy, namely wind, solar energy, geothermal energy, water energy, soil energy, air energy, biomass energy, landfill gas energy, sludge gas energy from wastewater treatment and biogas energy" (viz "Zákon č. 180/2005 Sb."). The further text of this chapter will convey the understanding and classification of renewables as amended by the previously cited legal act.

\subsection{Renewables Use for Electricity and Heat Generation}

Hydropower plants, pumped-storage hydropower plants, solar power plants, wind power plants (so far, there is no geothermal power plant in the Czech Republic) and biomass power plants are renewable sources of energy in the Czech Republic used for power generation, while solar collectors and biomass serve for the generation of heat.

The operation of Hydropower plants and pumped-storage power plants is the most environmentally friendly. We divide hydropower plants into hydropower plants, small hydropower plants ${ }^{162}$, pumped-storage hydropower plants and tidal power plants (not present on Czech territory). Power production is a simple process based on a gradient water flow which spins a turbine sharing the shaft with an electrical generator (together they create a turbo generator). The mechanical power of the flowing water in that manner changes into electrical, which is transformed and delivered to the places of consumption (see Hydropower Plants in the Czech Republic).

Pumped-storage hydropower plants have an advantage in that they can, in a particular manner, store electricity. Pumped-storage hydropower plants have two tanks, the upper and the lower. During a regular daily regime or at the peaks of its performance, the power plant produces a gradient water flow, where water from an upper tank falls to the one below and, therefore, spins a turbine ${ }^{163}$. If there is a surplus of electrical power left in the electrical network (mainly during the night), water is drawn from the bottom tank towards the upper one, while the power plant prepares for the further take-off at their day time peaks.

In the Czech Republic, there was 1,069 MWe installed in hydropower plants and 1,146.50 MWe in pumped-storage power plants. Approximately $70 \%$ of these hydropower plants and $100 \%$ of the pumped-storage power plants belong to CEZ. The largest hydropower plants are Orlik (364 MWe), Slapy (144 MWe), Lipno I (120 MWe), Kamyk (40 MWe) and Stechovice I (22.5 MWe), all owned by CEZ. The largest hydropower plants not belonging to this company are MVE Strekov (19.5 MWe) and MVE

162 A hydropower plant with less than $10 \mathrm{MW}$ of installed capacity.

163 For example, the Dlouhe Strane power plant with 650 MWe of installed capacity has a 534.3 metre fall between the upper tank with 2,580,000 $\mathrm{m}^{3}$ of volume and bottom tank with 3,405,000 $\mathrm{m}^{3}$. A comparison with the Chinese hydropower plant Thee Gorges Dam (San-sia Ta-pa) might be interesting here, having a $113 \mathrm{~m}$ fall and 26 x 852 MWe of installed capacity, which is all together $22,152 \mathrm{MWe}$, while active capacity amounts to $18,460 \mathrm{MWe}(26 \times 710 \mathrm{MWe})$. There are, moreover, another six 710 MWe blocks being built at the site. Following this build up, active capacity will reach 22,720 MWe, which is more than the entire capacity installed in all power plants in the Czech Republic. 
Pracov (9.75 MWe), owned by its daughter company CEZ Obnovitelne zdroje, s. r. o., MVE Vranov nad Dyji (18.9 MWe) and MVE Vir I (7.1 MWe) owned by E.ON Trend, s. r. o., MVE Nechranice (10 MWe) belonging to the state company Povodi Ohre, MVE Stvanice $(5.67 \mathrm{MWe})$ of the state company Povodi Vltavy and MVE Mezibori (7.6 MWe) owned by ENERGO - PRO Czech, s. r. o. (see ERÚ, 2010b, p. 9091). Hydropower plants and small hydropower plants in the Czech Republic amount to about ten.

There are only four pumped storage hydropower plants in the Czech Republic and all of them belong to the CEZ Group. These are the Dlouhe Strane power plant (650 MWe), the Dalesice power plant (450 $\mathrm{MWe})$, the Stechovice II power plant (45 MWe) and the Cerne Jezero I power plant (1.5 MWe). The first three belong to CEZ and the latter to CEZ Obnovitelne zdroje, s. r. o.

Solar power plants ${ }^{164}$ have a $10.2 \%(2,086 \mathrm{MWe})$ share of the entire installed capacity. Solar power plants acquire energy as a result of the photovoltaic effect, the process which converts solar radiation into electricity ${ }^{165}$. The capacity of photovoltaic cells are expressed in $\mathrm{kWp}$ (kilowattpeak), designating a maximum possible (peak) capacity of a photovoltaic power plant under laboratory solar conditions.

Generally, $1 \mathrm{kWp}$ occupies 8-10 $\mathrm{m}^{2}$ of surface and (under ideal conditions) produces approximately 1 MWh of electricity per year (see "Fotovoltaika," n.d.). A photovoltaic power plant runs even without the presence of direct sunlight, for example, in shadow, however the efficiency is in that case considerably lower. The intensity of solar radiation falling on $1 \mathrm{~m}^{2}$ at the height of atmosphere's frontier $(800 \mathrm{~km})$ is $1,360 \mathrm{~W} / \mathrm{m}^{2}$ per second. This value is named the solar constant and it de facto determines the limits of solar energy. While passing through the atmosphere, part is reflected, part is absorbed and scattered, striking the Earth's surface both directly as well as in the form of scattered (diffusive) and radiation reflected from clouds. When the skies are clear, the capacity of solar radiation at the Earth's surface does not go above 1 $\mathrm{kW} / \mathrm{m}^{2}$. When the skies are cloudy, only scattered radiation takes place, striking with a considerably lower (approximately 10 times lower) intensity (see Murtinger, 2008).

\begin{tabular}{|c|c|c|c|c|c|c|c|c|c|c|c|c|c|}
\hline Tab. & $\begin{array}{l}\text { The } \\
\text { Sur }\end{array}$ & $\begin{array}{l}\text { nou } \\
\text { e B }\end{array}$ & $\begin{array}{l}\text { f S } \\
\text { it a }\end{array}$ & $\begin{array}{l}\text { En } \\
\text { ngle }\end{array}$ & $\begin{array}{l}y \text { in } \\
40^{\circ}\end{array}$ & $\begin{array}{l}\mathrm{Cz} \\
\text { thy }\end{array}$ & Re & $\begin{array}{l}\operatorname{lic} w \\
/ \mathbf{m}^{2} / \mathbf{c}\end{array}$ & h & es & 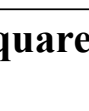 & & \\
\hline & I & II & III & IV & $\mathbf{V}$ & VI & VII & VIII & IX & $X$ & XI & XII & Year \\
\hline Prague & 1,228 & 2,027 & 3,034 & 4,149 & 4,846 & 4,644 & 4,930 & 4,577 & 3,475 & 2,729 & 1,140 & 833 & 3,141 \\
\hline Brno & 1,247 & 2,111 & 3,163 & 4,262 & 4,953 & 4,877 & 5,211 & 4,774 & 3,679 & 2,918 & 1,309 & 872 & 3,288 \\
\hline Plzen & 1,238 & 2,087 & 3,036 & 4,147 & 4,755 & 4,618 & 4,975 & 4,604 & 3,587 & 2,735 & 1,182 & 828 & 3,155 \\
\hline Ostrava & 1,321 & 2,138 & 2,990 & 3,890 & 4,689 & 4,556 & 4,916 & 4,471 & 3,370 & 2,858 & 1,372 & 976 & 3,135 \\
\hline Breclav & 1,343 & 2,204 & 3,315 & 4,429 & 5,046 & 5,100 & 5,411 & 4,925 & 3,990 & 2,975 & 1,441 & 935 & 3,433 \\
\hline As & 1,255 & 2,215 & 2,941 & 4,180 & 4,662 & 4,431 & 4,837 & 4,459 & 3,544 & 2,639 & 1,327 & 840 & 3,115 \\
\hline $\begin{array}{l}\text { Usti n. } \\
\text { L. }\end{array}$ & 1,231 & 2,080 & 2,956 & 4,063 & 4,788 & 4,507 & 4,751 & 4,405 & 3,365 & 2,677 & 1,207 & 841 & 3,078 \\
\hline
\end{tabular}

164 Solar power plants are basically split into photovoltaic power plants, using solar rays to produce power, and into solar heating power plants, which use solar thermal energy for heating a thermal transmitting medium for further use (heating of water, power production, etc.).

165 The particles of light, photons, fall on a cell and "boot" electrons out of it. The semiconductor structure of a cell then regulates the movement of electrons as utilizable direct current (see Beranovský a kol., 2007). 
The average daily amount of solar energy, for example, in Brno is $3,288 \mathrm{Wh} / \mathrm{m}^{2}$, which is 3.288 $\mathrm{kWh} / \mathrm{m}^{2}$. The other limit of solar panels is their efficiency which currently reaches values of around $15 \%$. Therefore, a square metre of solar panels can, under ideal conditions and the given efficiency, reach a yearly amount of approximately $180 \mathrm{kWh}$. Such a low capacity is enhanced by adding a surface of solar panels; the massive production of power and its transmission to the electrical network in that manner, therefore, stipulated the emergence of solar parks, which are photovoltaic power plants with higher capacities (above $500 \mathrm{kWp})$.

The best known solar parks in the Czech Republic are Ostrozska Lhota (0.702 MWp) and Busanovice I (0.693 MWp). In terms of the number of projects, the most successful companies are Energy 21 Group, which by March 1, 2011, owned and ran projects in the range of $61.86 \mathrm{MWp}$ (for example, Divcice 2.9 MWp, Rozvadov 2.9 MWp, Drzovice 3 MWp, Urcice IV 3.4 MWp, Tasov 3.2 MWp, Bojkovice 4.1 MWp, Kojetin $4 \mathrm{MWp}$, etc.) (see "Skupina Energy 21"). Czech and foreign investment groups and banking institutions also participate in the realization of the projects (see Vin ová, 2009). CEZ Obnovitelne zdroje, s. r. o. also owns several solar power plants, for example, Bezerovice (3.013 MWp), Bustehrad (2.396 MWp), Cekanice (4.48 MWp), Hrusovany (3.73 MWp), Zabocice (5.6 MWp) and Chynov (2.009 MWp) (see ČEZ, a. s., 2011a). Hundreds of other firms and households build, install and run solar power plants.

The very first solar power plant in the Czech Republic was the photovoltaic power plant Mravenecnik in Jeseniky, which was built in 1997 by CEZ with $10 \mathrm{kWe}$ of installed capacity. In 2003, it was moved to the site of the Dukovany nuclear power plant, where it produces electricity to this day. The largest solar plant in the Czech Republic is the photovoltaic power plant Ralsko Ra 1 with $38.3 \mathrm{MWp}$ of installed capacity ${ }^{166}$. Since 2010, the power plant has been in the ownership of CEZ which bought it from eEnergy Ralsko, a. s. (see "Největší solárni elektrárny," 2010). The second largest power plant is the photovoltaic power plant Vprek with 35.1 MWp. The construction was executed by Decci, a. s., which in February 2010, by closing an agreement on in-kind contribution of business, placed the operation of the Veprek power plant and the transmitting station Vranany into the main capital of FVE CZECH NOVUM, s. r. o., owned by the companies Decci, a. s., (63\%) and Berlanga Uzbekistan B.V. (37 \%). Finally, the third largest power plant is the Sevetin photovoltaic power plant belonging to the CEZ Group.

Wind power plants are power plants which produce electricity by utilizing the flow of air. The flow of air spins propeller blades, which then spin an electrical power generator. For their operation wind power plants require a region with an average wind speed higher than $6 \mathrm{~m} / \mathrm{s}$, which are rather rare in the Czech Republic. The regions in the Czech Republic which qualify as adequate sites for building wind power plants are Krusnohorsko, Jesenicko and Ceskomoravska vrchovina. Some of the places in these areas cannot be exploited since they qualify as protected areas (see Poncarová, 2008). In order to increase operating efficiency, wind farms emerge, respectively, a group of units of up to ten wind power plants. In the Czech Republic, wind power plants have a $1.3 \%$ (263 MWe) share of installed capacity in the power system. Wind energy is also an intermittent source (i.e. with oscillating production) which functions only in the presence of wind. For that reason, there has to be an adequate reserve for each megawatt from wind power plants, since their production is unpredictable and varies quickly ${ }^{167}$. Wind power plants are coupled with fast, stable and cheap sources, i.e. most frequently with gas fired power plants and hydropower.

166 It is a group of four photovoltaic power plants laying kilometres distante from each other with a respective installed capacity of 14.269 MWp, 12.869 MWp, 6.614 MWp and 4.517 MWp.

167 It is the same with photovoltaic power plants. 
The companies owning the largest wind power plants in the Czech Republic are Ecoenerg Windkraft GmbH \& Co. KG (42 MWe), Vetrne energie HL, s. r. o. (18 MWe), APB-PLZEN, a. s., (16.85 MWe), WIND FINANCE, a. s., (10 MWe), CEZ Obnovitelne zdroje, s. r. o. (9.6 MWe) and Green Lines Rusova, s. r. o. (7.5 MWe) (see ERÚ, 2010b, p. 94). There are tens of wind power plants in the Czech Republic.

Biomass power plants are, in principle, the same as steam power plants (see the chapter addressing the coal sector). The difference is that they combust (or combust in combination with fossil fuels) biomass, which is "the biodegradable fraction of products, waste and residues from the operation of agriculture and forestry and related industries, agricultural products grown for energy-production purposes, as well as the biodegradable fraction of separated industrial and municipal waste" (see "Zákon č. 180/2005 $S b$. .). In terms of energy use, the Czech Republic uses mainly wood (or separated waste), straw and other agricultural residues and livestock excrements, and separated municipal waste possible to utilize for energy purposes or gas products arising during the wastewater cleaning treatment (see ČEZ, a. s., 2006, p. 37). Biomass intended for use in power or heating plants usually goes through a process of modification (grinding, drying, pressing, pelletizing, gasification, etc.), while the calorific value reaches $12-15 \mathrm{MJ} / \mathrm{kg}$, depending on the plant, under the conditions of 15-30\% humidity (see ČEZ, a. s., 2003, cited according to ČEZ, a. s., 2006, p. 39).

From an environmental perspective, biomass combustion is based on the principle of a zero carbon cycle. During combustion, $\mathrm{CO}_{2}$ is released in an amount equal to that a plant used for its growth. This design, unfortunately, does not recognize the harmful emissions emerging during the agricultural work, such as planting, treatment and harvesting of crops, their modification for energy exploitation and their transportation. For that reason, the particular procedures require a thorough assessment (for example, local use) in order to get as close as possible to the zero carbon cycle principle. The advantage of biomass combustion, if it is not combusted in combination with fossil fuels, is the use of ashes as a highly quality manure. Biomass combustion in most cases also releases a lesser amount of sulphur fumes in comparison to fossil fuel combustion.

The largest power plants in the Czech Republic which are active in biomass combustion are Tisova I (1 block of $57 \mathrm{MWe}$ ), Porici (1 block of $55 \mathrm{MWe}$ ), Hodonin (1 block of $55 \mathrm{MWe}$ ) and Teplarna Dvur Kralova ( 1 block of $6.3 \mathrm{MWe}$ ), all in the possession of CEZ (see ERÚ, 2010b, p. 88). They used to be the brown coal fired power plants, and they are among the oldest power plants in the Czech Republic.

In the Czech Republic, biomass is however used rather for heat generation (resp. cogeneration) purposes. Table No. 7.2 presents heating plants, power plants and company-owned heating plants which are engaged in biomass combustion for heat (and power) generation. Biomass was in 2009 for heating purposes mostly used in Vysocina, located in the Usti and Liberec regions. The waste was for the same purposes mostly used in the Liberec region and in Prague (see Teplárenské sdružení České republiky, n.d.). 


\begin{tabular}{|c|c|c|}
\hline Facility & Type & $\begin{array}{r}\text { Yearly consumption of bio- } \\
\text { mass (tonnes) }\end{array}$ \\
\hline AES Bohemia Plana nad Luznici & Heating plant & 10,000 \\
\hline ATEL Energetika Zlin & Heating plant & 15,000 \\
\hline Dalkia Krnov & Heating plant & 63,000 \\
\hline Dalkia Novy Jicin & Heating plant & 3,400 \\
\hline ECK Generating Kladno & Heating plant & 46,000 \\
\hline Hodonin power plant (CEZ, a. s.) & Power plant & 169,000 \\
\hline Porici power plant (CEZ, a. s.) & Power plant & 125,000 \\
\hline Tisova power plant (CEZ, a. s.) & Power plant & 47,000 \\
\hline Iromez Pelhrimov & Heating plant & 40,000 \\
\hline Komterm Jitex Pisek & Company-owned heating plant & 50,000 \\
\hline Komterm Koprivnice & Company-owned heating plant & 15,000 \\
\hline MMV Mimom & Heating plant & 10,000 \\
\hline Mondi Steti & Company-owned heating plant & 150,000 \\
\hline Plzenska teplarenska & Heating plant & 270,000 \\
\hline Bystrice pod Pernstejnem heating plant & Heating plant & 17,000 \\
\hline Dvur Kralove heating plant (CEZ, a. s.) & Heating plant & 7,000 \\
\hline Strakonice & Heating plant & 3,000 \\
\hline Teplarny Brno & Heating plant & 7,000 \\
\hline Teplospol Jindrichuv Hradec & Heating plant & 5,000 \\
\hline Trebicska tepelna & Heating plant & 35,000 \\
\hline \multirow[t]{2}{*}{ Zatecka teplarenska } & Heating plant & 30,000 \\
\hline & In total & $1,117,400$ \\
\hline
\end{tabular}

Solar collectors are the second renewable source used in the Czech Republic for generating heat. A solar collector is a device serving for the direct absorption of solar radiation and heating of fluids for a direct use or for heating another fluid in a heat exchanger, which then circulates, for example, through a central heating supply system. A solar collector is composed in such a manner as to absorb solar radiation to maximum effect, then to convert it into heat without reverse emission and deliver this heat to the heating fluid with a minimum loss of thermal energy during the transmission and streaming processes (see Eckertová, 1996, p. 9). A solar collector is a closed, thermally insulated case consisting of permeable glass, an absorber placed underneath the glass (usually a black board which warms up to $120^{\circ} \mathrm{C}$ ), a system of tubes with a thermal transmission medium (water, oil, air or gas), thermal insulation and an adequate exchanger (see ČEZ, a. s., 2006, p. 12). There is no larger solar power plant within our territory and, due to inadequate weather conditions, it is likely that there will never be one. Solar collectors are, therefore, used on local bases by single households, mainly for the heating of water and space, which can, however, result in big savings of total energy consumption. 


\subsection{The Regulatory and Safety Framework of the Renewables Industry}

The local legal framework for renewable sources of energy has been formulated by four legal acts. Those are Act No. 180/2005 Coll., on the promotion of electricity production from renewable energy sources and amending certain acts (and its executive regulations), Act No. 406/2000 Coll., on energy management (and its executive regulations), Act No. 458/2000 Coll. on business conditions and public administration in the energy sector and on amendment to other laws (and its executive regulations) and Act No. 165/2012 Coll. on supported energy sources and on amendment to other laws.

Act No. 180/2005 Coll. pioneered the term 'green bonus', indicating "the financial amount increasing the market price of electricity that is paid by the operator of the regional grid system or the operator of the transmission system to the producer of electricity from renewable sources, taking account of reduced damage to the environment resulting from use of a renewable source compared to combustion of fossil fuels, of the type and size of the production plant and of the quality of electricity supplied" (see "Zákon č. 180/2005 Sb.").

According to Act No. 180/2005 Coll., the level of this green bonus is determined by the Energy Regulatory Office, which is, through the means of ordinances and, primarily, of cost regulation, the main regulatory body for renewable sources of energy (together with the Ministry of Industry and Trade). The Office is, among other things, engaged in support of the exploitation of renewable and secondary sources of energy, the combined production of power and heat, and protection of consumers' interests in these fields of energy sectors, where competition is not possible.

Except for state aid supporting the utilization of renewables, Article 4 of Act No. 180/2005 Coll. should not be left out as it obliges the operators of the regional distribution systems and the operators of the transmission system "to purchase all electricity from renewable sources eligible for promotion and to conclude a supply contract, if a producer has offered electricity from renewable sources" (see "Zákon c. 180/2005 Sb."). "Assumption of responsibility for deviation pursuant to special regulation" is of extreme importance as well (see "Zákon č. 180/2005 Sb."). The cited passages of Act No. 180/2005 Coll. signify the obligation of preferential purchase of electricity from renewables for all licensed third parties which have a license approved by the Energy Regulatory Office and, accordingly, the responsibility on behalf of CEPS for maintaining the stability of the network in the event of unstable production of electricity from renewables.

At the level of the supranational legal dimension, there were two directives decisive for the renewables sector, namely Directive 2001/77/EC of the European Parliament and of the Council of March 27, 2001, on the promotion of electricity produced from renewable energy sources in the internal electricity market (see "Directive 2001/77/EC") and Directive 2003/30/EC of the European Parliament and of the Council of May 8, 2003, on the promotion of the use of biofuels or other renewable fuels for transport (see "Directive 2003/30/EC"). Both were, however, replaced by the most recent Directive of the European Parliament and of the Council 2009/28/EC of April 23, 2009, on the promotion of the use of energy from renewable sources and amending and subsequently repealing Directives 2001/77/EC and 2003/30/EC (see "Directive 2009/28/EC"). This directive has been fully implemented in the National Renewable Energy Action Plan from July 2010 (see MPO, 2010c), the document which, upon request amended by the Directive, sets the national goals of member states regarding the share of energy from renewables in sectors of transportation and of power and heat generation and air conditioning by 2020. 
In terms of obligations resulting from membership in international organizations, the Czech Republic has received five significant legal obligations (see table No. 7.3). While the first can be considered as completed, the second one has even been exceeded by $0.3 \%$, the third also seems achievable with regard to present development in the sector, while the fourth obligation can be considered as, at this point, hardly achievable. The fifth obligation, although very ambitious, should be achievable (according to Zámyslický, 2009).

\begin{tabular}{|l|l|}
\hline Tab. 7.3: Obligations Resulting from Membership in International Organizations \\
\hline Obligation & Obligation as Amended by \\
\hline Reduction in greenhouse gas emissions by $8 \%$ by 2012. & Kyoto Protocol \\
\hline $\begin{array}{l}\text { A greater renewable energy share in gross final consumption, reaching the level of } \\
8 \% \text { by } 2010 \text { and the level of } 15 \% \text { by } 2030 .\end{array}$ & $\begin{array}{l}\text { EU Accession Agreement (Athens, } \\
\text { April 16, 2003) }\end{array}$ \\
\hline $\begin{array}{l}\text { A greater renewable energy share in gross final consumption, reaching the level of } \\
13 \% \text { by } 2020 .\end{array}$ & $\begin{array}{l}\text { Directive of the European Parliament } \\
\text { and of the Council 2009/28/EC }\end{array}$ \\
\hline $\begin{array}{l}\text { Reaching a renewable energy share of } 10 \% \text { in all sorts of transportation displayed } \\
\text { on gross final energy consumption in transportation in the Czech Republic by 2020. }\end{array}$ & $\begin{array}{l}\text { Directive of the European Parliament } \\
\text { and of the Council 2009/28/EC }\end{array}$ \\
\hline $\begin{array}{l}\text { Emissions from sectors not covered by the EU ETS will not exceed 2005 levels in- } \\
\text { creased by } 9 \% \text { by 2020. }\end{array}$ & EU Climate and Energy Package \\
\hline Source: T. Vlček from publicly available sources \\
\hline
\end{tabular}

\subsection{Demand Forecast}

In comparison with the objective declared in Directive 2009/28/EC, the National Renewable Energy Action Plan of the Czech Republic foresees an objective of a renewable energy share in gross final energy consumption of $13.5 \%$ and accomplishment of an objective of renewable energy share in gross final consumption in transportation of $10.8 \%$ (see MPO, 2010c, p. 2), scheduled according to the plan presented in table 7.4.

Tab. 7.4: Scenario of Renewable Energy Share in Final Energy Consumption According to the National Renewable Energy Action Plan of the Czech Republic

\begin{tabular}{|l|c|c|c|c|c|c|c|c|}
\hline Year & $\mathbf{2 0 0 5}$ & $\mathbf{2 0 0 6}$ & $\mathbf{2 0 0 7}$ & $\mathbf{2 0 0 8}$ & $\mathbf{2 0 0 9}$ & $\mathbf{2 0 1 0}$ & $\mathbf{2 0 1 1}$ & $\mathbf{2 0 1 2}$ \\
\hline Share (\%) & 6.1 & 6.2 & 7.0 & 7.0 & 7.4 & 8.3 & 9.4 & $10 ., 1$ \\
\hline Year & $\mathbf{2 0 1 3}$ & $\mathbf{2 0 1 4}$ & $\mathbf{2 0 1 5}$ & $\mathbf{2 0 1 6}$ & $\mathbf{2 0 1 7}$ & $\mathbf{2 0 1 8}$ & $\mathbf{2 0 1 9}$ & $\mathbf{2 0 2 0}$ \\
\hline Share (\%) & 10.8 & 11.3 & 11.8 & 12.1 & 12.5 & 12.9 & 13.2 & 13.5 \\
\hline
\end{tabular}

Note: data in italics are figures planned according to the Scenario, while other figures represent actual levels.

Source: The Ministry of Industry and Trade, 2010d, p. 88.

The state intends to reach these levels through investment support to research and development, investment support as part of state programs of support and structural funds drawing from the EU financial resources, by changing the policy of waste management and by supporting the waste-to-energy principle, through suitable and adequate operational support to power production, by raising public awareness, by simplifying and shortening the approval process for building facilities of electrification system and through other means (see MPO, 2010c, p. 89-97). 
The most recent, so far unapproved Revision of the State Energy Concept from August 2012 is however considerably more realistic as it counts on renewable energy's share in final energy consumption at the level of 17-22\% by 2040 (see table No. 7.5). Accordingly, the occurrence of the increasing share of renewables at the expense of solid fuels is entirely evident here. According to the aforementioned Revision, an approximately $20 \%$ reduction of solid fuels in final consumption will be replaced with gas and, above all, nuclear sources.

\begin{tabular}{|c|c|c|c|c|c|c|c|c|}
\hline \multicolumn{9}{|c|}{$\begin{array}{l}\text { Tab. 7.5: The Shares of Solid, Liquid and Gas Fuels in Energy Resource Consumption According } \\
\text { to the State Energy Policy of the Czech Republic from } 2004 \text { and Its Revisions from Feb- } \\
\text { ruary } 2010 \text { and August } 2012 \text { (in \%) }\end{array}$} \\
\hline \begin{tabular}{|l|} 
Type of Fuel \\
\end{tabular} & $\begin{array}{c}\text { Level in } \\
2000\end{array}$ & $\begin{array}{c}\text { Level in } \\
2005\end{array}$ & $\begin{array}{c}\text { Level in } \\
2008\end{array}$ & $\begin{array}{c}\text { Long-Term } \\
\text { Goal (SEP } \\
\text { 2004) by } 2030\end{array}$ & $\begin{array}{l}\text { "Green" } \\
\text { Scenario } \\
\text { (SEP 2004) } \\
\text { year 2030 }\end{array}$ & $\begin{array}{l}\text { Revised SEP } \\
(2 / 2010) \\
\text { Scenario by } \\
\quad 2030\end{array}$ & $\begin{array}{l}\text { Revised SEP } \\
\text { Scenario } \\
(2 / 2010) \text { by } \\
2050\end{array}$ & $\begin{array}{c}\text { Revised } \\
\text { SEP } \\
(8 / 2012) \\
\text { Target } \\
\text { Values by } \\
2040 \\
\end{array}$ \\
\hline Solid & 52.4 & 42.5 & 45.3 & $30-32$ & 30.5 & 24 & 20 & $12-17$ \\
\hline Gas & 18.9 & 21.6 & 15.7 & $20-22$ & 20.6 & 20 & 21 & $20-25$ \\
\hline Liquid & 18.6 & 15.7 & 20.9 & $11-12$ & 11.9 & 20 & 19 & $14-17$ \\
\hline Nuclear & 8.9 & 16.5 & 15.3 & $20-22$ & 20.9 & 25 & 25 & $30-35$ \\
\hline Renewables & 2.6 & 5.4 & 2.9 & $15-16$ & 15.7 & 11 & 15 & $17-22$ \\
\hline
\end{tabular}

Source: Státní energetická koncepce, 2004, p. 11-12, 40-49; Ministerstvo průmyslu a obchodu, 2010a, p. 77-92; Český statistický úřad, 2008; Ministerstvo průmyslu a obchodu, 2012, p. 20-21.

The Independent Energy Commission, the Paces Commission, indicated that the Czech Republic has the potential to produce $49.8 \mathrm{TWh}$ of electricity and $152 \mathrm{PJ}$ of heat from renewables (see ÚVČR \& NEK, 2008, p. 129). It simultaneously noticed, however, that the expected development will be lower than that (see table No. 7.6). The comparison of current figures (table No. 7.7) with this expected development brings us to the conclusion that the actual development is more rapid than that estimated by the Paces Commission. By 2030, the production of electricity and heat might, therefore, potentially range between 22.46 and $49.8 \mathrm{TWh}$, respectively 127.34 and $152 \mathrm{PJ}$.

\begin{tabular}{|c|c|c|c|c|c|c|}
\hline \multicolumn{7}{|c|}{ Tab. 7.6: Expected Development of Electricity and Heat Production from Renewables by 2030} \\
\hline \multicolumn{7}{|c|}{ Electricity (TWh) } \\
\hline Type of plant & 2005 & 2010 & 2015 & 2020 & 2025 & 2030 \\
\hline Hydropower & 2.38 & 2.14 & 2.24 & 2.43 & 2.46 & 2.48 \\
\hline Wind & 0.02 & 0.60 & 1.75 & 2.55 & 4.02 & 4.71 \\
\hline Biomass & 0.73 & 1.62 & 3.31 & 5.26 & 6.80 & 8.02 \\
\hline Geothermal & 0.00 & 0.00 & 0.13 & 0.48 & 0.94 & 1.58 \\
\hline Solar & 0.00 & 0.15 & 0.50 & 0.98 & 2.73 & 5.67 \\
\hline In total & 3.13 & 4.51 & 7.93 & 11.70 & 16.94 & 22.46 \\
\hline \multicolumn{7}{|c|}{ Heat (PJ) } \\
\hline Type of plant & 2005 & 2010 & 2015 & 2020 & 2025 & 2030 \\
\hline Biomass & 44.14 & 62.36 & 84.30 & 93.48 & 99.80 & 105.52 \\
\hline Geothermal & 0.55 & 2.20 & 5.73 & 10.51 & 14.40 & 17.70 \\
\hline Solar & 0.10 & 0.28 & 1.03 & 2.25 & 3.08 & 4.12 \\
\hline In total & 44.79 & 64.84 & 91.06 & 106.24 & 117.28 & 127.34 \\
\hline
\end{tabular}




\begin{tabular}{|l|c|c|c|c|c|c|c|c|c|}
\hline Tab. 7.7: Gross Production of Electricity from Renewables (TWh) \\
\hline Type of plant & $\mathbf{2 0 0 4}$ & $\mathbf{2 0 0 5}$ & $\mathbf{2 0 0 6}$ & $\mathbf{2 0 0 7}$ & $\mathbf{2 0 0 8}$ & $\mathbf{2 0 0 9}$ & $\mathbf{2 0 1 0}$ & $\mathbf{2 0 1 1}$ & $\mathbf{2 0 1 2}$ \\
\hline $\begin{array}{l}\text { Small hydropower plants with } \\
\text { less than 10 MWe }\end{array}$ & 0.903 & 1.071 & 0.964 & 1.002 & 0.967 & 1.083 & 1.239 & 1.018 & 1.026 \\
\hline $\begin{array}{l}\text { Hydropower plants with more } \\
\text { than 10 MWe }\end{array}$ & 1.116 & 1.309 & 1.586 & 1.077 & 1.057 & 1.347 & 1.551 & 0.945 & 1.103 \\
\hline Biomass & 0.533 & 0.552 & 0.729 & 0.993 & 1.231 & 1.437 & 1.512 & 1.683 & 1.803 \\
\hline Biogas + landfill gas & 0.037 & 0.085 & 0.173 & 0.183 & 0.214 & 0.414 & 0.599 & 0.933 & 1.472 \\
\hline $\begin{array}{l}\text { Biodegradables from municipal } \\
\text { waste }\end{array}$ & 0.010 & 0.011 & 0.011 & 0.011 & 0.012 & 0.011 & 0.036 & 0.090 & 0.087 \\
\hline Wind power plants & 0.009 & 0.021 & 0.049 & 0.125 & 0.245 & 0.288 & 0.335 & 0.397 & 0.416 \\
\hline Photovoltaic systems & 0.0001 & 0.00007 & 0.0002 & 0.002 & 0.013 & 0.089 & 0.616 & 2.182 & 2.149 \\
\hline $\begin{array}{l}\text { Total consumption of electricity } \\
\text { from renewables }\end{array}$ & 2.610 & 3.050 & 3.513 & 3.394 & 3.738 & 4.669 & 5.887 & 7.248 & 8.055 \\
\hline Source: Energetický regulační úr̆ad, 2013. & & & & & & \\
\hline
\end{tabular}

Forecasts for decades in advance are, however, always too broad estimates for events that could actually happen in reality. Any significant development of renewables is obstructed by a string of objective and subjective obstacles, which will be discussed in the following part.

\subsection{Criticism and Development of Renewables}

The system of state promotion of renewables was set so generously that, for example, the target of 1,695 MWe of installed capacity in photovoltaic power plants, which the Czech National Renewable Energy Action Plan set for 2020, has been exceeded already in 2010. The cause of this boom lies in a combination of reduction of investment costs in photovoltaic and wind power plants construction on one hand and excessively high preferential treatment through state support on the other hand, which led to a significant development of the renewable sector and proliferation of companies engaged in installation of domestic and industrial power plants. While in 2005 the purchase price of electricity from photovoltaic power plants was $6.04 \mathrm{CZK} / \mathrm{kWh}$, the Energy Regulatory Office more than doubled this value in 2006, to 13.2 CZK/ $\mathrm{kWh}$ (which is about twelve times the market price of electricity) (see Zajíček, 2010, p. 62).

The originally well-planned program was supposed to motivate citizens to accept renewables, to get them to trust in their potential and also to increase renewable energy's share in total production and consumption of electricity in the Czech Republic, in order to meet the required commitments resulting from international agreements. In reality, however, citizens and the industrial sector identified the opportunity and prospect of easily obtainable and guaranteed state money over the course of several years, and photovoltaic plants consequently experienced an incredible expansion. Not even the Energy Regulatory Office was capable to manage the situation, since the law allowed it to lower the purchase price of electricity from renewables by at most $5 \%$ per year.

These events, naturally, led to growing risk from problems arising inside the transmission, and mainly inside the distribution, system. The progress predicted by the National Action Plan was supposed to have been at a notably easier pace and would thus have allowed for simultaneous development of infrastructure. 
Given that the installed capacity of photovoltaic power plants preceded the National Action Plan, but the development of infrastructure and facilities was running according to the plans, it came to the collision of renewables development with the potential of existing technical foundations. This discrepancy finally led to a situation which Jan Zeman describes as a "renewable energy crisis" (see Zeman, 2011, p. 44-48).

The crisis was triggered by the mentioned discrepancy and erupted on February 16, 2010, when the companies CEZ Distribuce, a. s. and E.ON Distribuce, a. s. met the request of CEPS and stopped approving applications for the installation of new photovoltaic and wind power plants into the network (see Zeman, 2011, p. 44-45). If we observe table No. 7.8, it is clear that it was impossible to react to this unexpected and unanticipated development of photovoltaic (and wind) power plans in a timely manner by developing the technical base of the electrification system.

\begin{tabular}{|c|c|c|c|c|c|c|c|c|c|}
\hline Year & 2004 & 2005 & 2006 & 2007 & 2008 & 2009 & 2010 & 2011 & 2012 \\
\hline $\begin{array}{l}\text { Inst. ca- } \\
\text { pacity }\end{array}$ & 0.13 & 0.13 & 0.74 & 3.4 & 54 & 464.4 & $1,959.10$ & $1,971.0$ & $2,086.0$ \\
\hline
\end{tabular}

These figures are the basis for specific total expenditures intended for photovoltaic and wind power plants inside the Czech electrification system, which are outlined in table No. 7.9. Miroslav Zajicek argues that this figure is, for example, approximately equal to the figure which would cover pension reform or to two to three times the estimated costs for completion of the Temelin nuclear power plant (see Zajíček, 2010, p. 63).

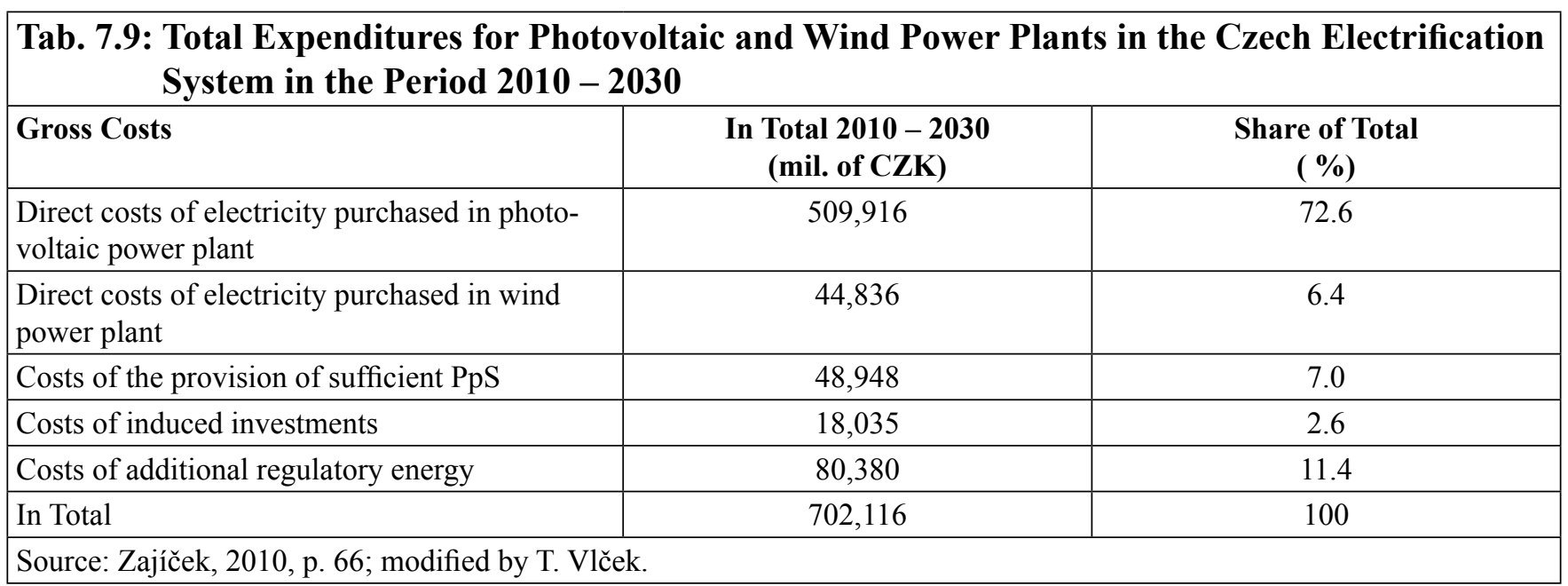

The state is, of course, aware of the situation and fighting it in its own typical manner. In November 2010, Amendment No. 330/2010 Coll. and, in December 2010, Amendment No. 402/2010 Coll. to Act No. 180/2005 Coll., on the promotion of electricity production from renewable energy sources and amending certain acts, were passed and entered into force on March 1, 2011. The amendments introduced several changes, among others that the state would from now on support only those photovoltaic power 
plants connected to the distribution network, i.e. photovoltaic systems producing electricity or heat only for household purposes would not be supported. Solar farms will also be cut off from support, whereas the state support will go only to photovoltaic power plants placed on roofs and buildings with installed capacity of no more than $30 \mathrm{kWp}$. A retroactive solar tax of $26-28 \%$ was introduced for all photovoltaic facilities launched in 2009 and 2010. An exemption was approved only for devices on house rooftops with a capacity reaching less than $30 \mathrm{kWp}$. The changes also affect the regulation of purchase prices performed by the Energy Regulatory Office. For example, should renewables in the year the new regulations affecting purchase prices apply reach a return on investments of less than 11 years, they are subject to not more than $5 \%$ of the yearly reduction of purchase prices. In 2011, the purchase price of electricity from renewables was set at $7.5 \mathrm{CZK} / \mathrm{kWh}$.

These amendments were understood as a temporary solution, while the conceptual solution found its expression in a Bill on supported sources of electricity, which was supposed to replace Act No. 180/2005 Coll. It entered into force on January 1, 2013, as Act No. 165/2012 Coll. on supported energy sources and on amendment to other laws, which simultaneously annulled Act No. 180/2005 Coll. Following its approval by the Chamber of Deputies and the Senate on January 31, 2012, the president, Vaclav Klaus, vetoed it in March of the same year. The arguments for his position were the widening of the scope of supported sources of energy to include biomethane and low legislative quality requiring "a string of regulations implemented through the means of the relevant legislature", whereas "such regulations would represent a violation of the Constitution and of the Charter of Fundamental Rights and Freedoms, since the law permits to set only technical details of its enforcement via ordinances and regulations and not citizens' own rights and obligations" (see "Stanovisko prezidenta"). Act No. 165/2012 Coll. was nonetheless passed on May 9, 2012, when the Chamber of Deputies outvoted the president's veto with an overall majority.

The Act in reality adds some new promoted sources, namely the support of heat generation from renewables, biomass and geothermal with a capacity of more than $200 \mathrm{~kW}$ connected to the system of central heating. The Act was closely tied to Directive 2009/28/EC. According to the National Renewable Energy Action Plan, the connection of renewables into the network will be, from now on, capped with a yearly capacity. Even though Directive 2009/28/EC understands the levels of the National Action Plan as the minimum, the new Act No. 165/2012 Coll. understands them as the maximum. These caps are, according to the National Action Plan, calculated every year not only for the entire Czech Republic, but for individual regions as well. Should they reach the upper limit, no further connection approvals will be granted until the following year. Support for photovoltaic power plants has recently been limited to a production capacity of less than $30 \mathrm{kWp}$ that is located on the roof or perimeter wall of a building attached to the ground via firm foundations registered in the real estate registry (see "Zákon ze dne 31. ledna 2012").

The amendments and the new act have contributed to the stabilization of the renewables sector, beneficial mainly for photovoltaic power plants. The price to be paid is, naturally, high. The abrupt suspension of the sector and a significant change in terms led to the bankruptcy of about ten companies trading in photovoltaic technologies, while the state is financially burdened with support for decentralized production and renewables for the coming decades (see below), renewables have been discredited in the public eye to a great extent and the likelihood that the obligation of a $13 \%$ renewable energy share in gross final energy consumption by 2020 will be met is very low. In 2004, the production of electricity from renewables reached a figure of $2.61 \mathrm{TWh}$ and a $3.80 \%$ share in consumption. In 2012, production of electricity from renewables amounted to $8.06 \mathrm{TWh}$, while the share in consumption was $11.43 \%$ (see Energetický regulační úřad, 2013). In this context, it depends on whether we are really speaking of positives figures.

The Czech Republic accepted an obligation to increase the share of renewable energy in gross final energy consumption to $13 \%$ by 2020 . It should be noted that, with respect to unstable production of electricity from renewables, information about installed capacity does not provide us with almost any insights. 
For the purposes of the forthcoming argument, let us speak about electricity only. According to calculations, 9,880 MWe of installed capacity in photovoltaic power plants is necessary to produce electricity from photovoltaic plants amounting to $10 \%$ of Czech consumption (with an estimated $15 \%$ utilization of sources) and 2,970 MWe of installed capacity in wind power plants to produce electricity from wind plants amounting to $10 \%$ of Czech consumption (with an estimated $25 \%$ utilization of sources) (see Vaculík, Novotný, \& Kaláb, 2011, p. 289). Following these calculations (and aware that the installed capacity of the Czech electrification system as of December 31, 2012, was 20,520 MWe in total), it is rather apparent that we should intensely search for solutions which result in a better exploitation of renewables, alternative methods of accumulation of produced power and new alternatives for the management an overburdened network (see Vaculík, Novotný, \& Kaláb, 2011, p. 289).

There are indications that we might expect a crisis similar to the photovoltaic one to be repeated in the field of biomass as well. State support will, according to Deputy Minister for Industry and Trade, Tomas Huner, "(...) proceed according to the National Action Plan. The Plan counts on a $13 \%$ share of renewables in energy production in 2020" (see Zelenka \& Mařík, 2011, p. 11-12). In his interview for Ekonom magazine, he stated that "(...) purchase prices will serve to promote electricity from the combined production of electricity and heat. This will involve biomass combustion in combination with classic fuels. (...) we have established caps for biomass' energy share and suggest a cap for the electricity purchase price amounting to 6,000 CZK/MWh" (see Zelenka \& Mařík, 2011, p. 13).

Biomass is simply the most traditional source of energy, de facto tied to the history of humanity. The initiation of plant combustion for heating and light purposes reaches back into the past. Biomass has four main positives: 1 . it is a renewable and inexhaustible source, if rationally used; 2 . if rationally used, it is $\mathrm{CO}_{2}$ neutral; 3. it can be transformed into different solid, gaseous and liquid biofuels and, at the same time, it can be stored and then used when needed; 4. its use contributes to the development of agricultural regions by exploiting manpower, mechanization and by enhancing the local economy (see Weger, 2008, p. 9).

Biomass can be divided into two basic categories, residual and deliberately grown biomass. Residual biomass consists of logging waste, straw and other harvesting residues, cowshed manure, organic residues from the manufacturing industry (paper and wood processing, sawmill, milk and food processing, etc.). First generation energy crops (for example, oilseed rape, oil palm tree, wheat or corn) and second generation energy crops (poplar and willow trees, eucalyptus, sorrel, millet, etc.) are deliberately grown biomass.

Biomass has great prospects as a source of energy. The combustion of deliberately grown crops causes controversy in situations where they happen to share a field with crops intended for the food industry. The result of state subsidies for renewable energy is that farmers find the growing of energy crops more beneficial than the growing of classic agricultural crops. Forest owners start selling wood and wood residues to heating and power plants, because the profit is, with state support included, higher than if the same materials were sold to paper mills and other wood processing sectors. So far, there is no need to be concerned about security of food supplies in the Czech Republic, because, should the utilization of biomass be rational and should the plans of Ministry of Industry and Trade be executed, approximately $2 / 3$ of arable land should remain for the production of food. The Ministry of Agriculture allocated 2.07 million of hectares out of a total 3.05 million hectares of arable land (respectively out of a total 4.26 million hectares of all agricultural land) for security of food supplies purposes (see ÚVČR \& NEK, 2008, p. 123). Even Jan Veleba, the Chairman of the Czech Agrarian Chamber, does not see the production of energy crops either as an isolated or crucial cause of the world food supply crisis. Moreover, if "we manage "to start up' second generation biofuels, we limit their production to the processing of kernels and there will be no problems" (see Trnavský, 2008a, p. 24). 
Biogas produced in biogas stations has been a very popular product in the field of the biomass economy recently. Biogas stations are facilities which process a wide range of materials or waste of organic origins by employing the process of anaerobic digestion ${ }^{168}$ in the absence of air inside closed reactors (see Bačík, 2008, p. 27). It can be split into three categories: agricultural biogas stations, co-fermentation (industrial) biogas stations and municipal biogas stations. Agricultural biogas stations process dung or manure, co-fermentation biogas stations process slaughterhouse waste, sediments from specific facilities, sediments from wastewater cleaning treatments, fats, fleshed bone meal, blood from slaughterhouses, etc., while municipal biogas stations use biological waste from households, restaurants, canteens, the maintenance of public green spaces, etc. (see Trnavský, 2008a, p. 24; Bačík, 2008, p. 28).

Biogas can be utilized in many different ways: direct combustion, power and heat generation, for combustion engine power, etc. Biomass processing can deliver various products, such as biogas, synthetic oil, ETBE and MTBE, vegetable oil, biomethanol, engine oil and others.

Unlike the use of sun or wind (for power or heat production), biogas has one indisputable advantage it is possible to store it and it is also perfectly manageable and usable when necessary. While the intensity of solar radiation is less in winter and the sun does not shine at night, i.e. when we need energy the most (for heating and light), biogas, respectively biomass can be stocked up and used without interruption. Moreover, by increasing the content of methane above the level of $98 \%$, biogas can be modified to acquire a natural gas-like quality, which enhances its value. Biogas stations are, among other things, facilities built in the spirit following the modern trend of energy decentralization, they are, with regard to their size, used like local sources and as they process waste materials, they also count as very environmentally friendly. Biogas stations are not so visible to the public, perhaps because power production from biogas in 2010 reached a mere 113 MWe of installed capacity (624 GWh) (see MPO, 2010c, p. 68). Its potential, either in terms of protection of the environment, renewables development or production of power, heat and other products, is not insignificant. According to the National Action Plan, the development should reach 417 MWe of installed capacity $(2,871 \mathrm{GWh})$ by 2020 (see MPO, 2010cp. 70), which is certainly not an exaggerated figure.

"The geographical location of its territory and geological and climate conditions gave the Czech Republic a perpetual, but to a significant extent limited, potential for the development of renewable sources. The Czech Republic does not have a sufficient potential at its disposal to develop the utilization of wind, solar energy or geothermal energy. The environmental contribution of the developing combustion of emission biomass is questionable, since the theory of zero $\mathrm{CO}_{2}$ balance is, in the case of biomass, only play on words. The only relevant renewable sources in the Czech Republic are hydropower plants, although a great measure of their potential has been already exploited" (see Kavina, 2009, p. 321). This is how Pavel Kavina, Director of Raw Materials and Energy Security Department at the Ministry of Industry and Trade, assesses the state of renewables in the Czech Republic. The Paces Commission is notably more positive by claiming that the Czech Republic, at the current level of knowledge, for example, possesses the potential to increase power production from the 0.15 TWh per year recorded in 2010 to 5.67 TWh per year by 2030 and even 18.24 TWh per year by 2050 in the photovoltaic sector (see ÚVČR \& NEK, 2008, p. 123).

Based on the previously reviewed data, it seems that we should rather agree with the position of the Czech Ministry of Industry and Trade. Renewables would not be competitive (and they are still not) without abundant state aid. The DUHA movement argues that "the Czech Republic - a country with a strong

168 Anaerobic digestion is the biological degradation of organic materials in the absence of air. The result of this process is a biologically stabilized substrate, with a highly fertilizing effect, and biogas with a 55-70\% share of methane and a calorific value around 18-26 MJ/m³ (see Mužík \& Kára, 2008, p. 22). 
tradition of engineering industry - will benefit from the development of the new (renewables) sector" (see Holub, Mikeska, \& Kotecký, 2006, p. 3). Here we must agree with the latter, but with keeping in mind that the aid issue has been, however, a vital foundation of the entire renewables sector. A counter argument is the fact that each industry sector had its own "birth period" during which it required subsidies in order to become competitive. Table No. 7.10. showcases capital expenditure for science and research in various energy sectors, which brings us to the conclusion that the promotion of science and research in the field of conventional nuclear energy alone is more than 4.5 times larger than renewables support. ${ }^{169}$ Every industry sector has gone and must go through its own development. Should the support reach the same extent as that the nuclear power industry had, we can expect a considerable increase in stability, operational security, efficiency and other features of renewables. The problem which the renewable sector presently faces is that subsidies push it artificially onto the market without previously letting it go through its own development.

\section{Tab. 7.10: A Showcase of Capital Expenditure for Science and Research Promotion across Vari- ous Energy Sectors}

\begin{tabular}{|l|c|}
\hline Structure of R\&D Capital Expenditure & Expenditures (billion USD) \\
\hline Conventional nuclear energy & 42,236 \\
\hline Fossil fuel energy & 17,487 \\
\hline Nuclear fission & 14,647 \\
\hline Fast reactors & 14,106 \\
\hline Renewables & 9,277 \\
\hline Energy saving measures & 8,362 \\
\hline Source: Šafaŕk, 2000, p. 59. & \\
\hline
\end{tabular}

If we compare the renewables sector of the Czech Republic with neighbouring Germany, we can conclude that, while the discourse in Germany has already gone through the phases of "if" and "how" and is currently in the phase of "when", we in the Czech Republic still oscillate somewhere at the frontier of the phase "if" and "how". Renewables are essentially not bad - quite the contrary. It is, however, always necessary to take the security of entire energy sector and balanced energy mix into consideration. The objective limits for the development of renewables may be found in the inadequate natural conditions of the Czech Republic and still low efficiency and stability of energy production from renewables as well. There is, moreover, always a shortage of renewables for completing the binding goals set by the EU, and therefore massive development is required. This will, however, mean a consequent rise in the massive risk induced by implementation of renewables into the operating process of the entire electric power industry and power industry in the Czech Republic.

Power should be produced in large amounts in a stabile manner over the smallest surface possible, all of which renewables are incapable of providing. Vladimir Vlk, Director of the Department of Sustainable Energy and Transport at the Ministry of Environment argues that "we anticipate that the exploitation of alternative and renewable sources of energy will first take place in the municipal power industry and then in smaller places and municipalities in the second. (...) We should aim at (...) setting up less centralized

169 The figure, nonetheless, dates to 2000 - the figures after that date are considerably higher. 
sources inside municipalities, for example, a facility for wood cut-offs and pellet production or a biogas station" (see "Podporuji využivání," 2008, p. 8). It is exactly here that we should recognize by far the most appropriate utilization of renewables as well as by far the greatest contribution of renewables to the entire state power industry.

Renewables will remain complementary sources for a long time. This should not be taken negatively, the sharply dialectical character of present energy sector is directed towards the increasing use of renewables anyways. The attention should, however, be paid to recklessness and imprudent support. The focus should be on supporting the field, for example, which would impose almost zero costs. Even a relatively profitable biomass economy appears uneconomic in comparison with waste-to-energy, that is exploitation of waste which is "made by itself". Support and conceptual and rational development should go to projects implementing geographical and national particularities, adequate conditions and having prospects for the future. By comparing waste-to-energy, for example, with a project for geothermal energy utilization in terms of their potential on our soil, it is entirely clear which of the projects would have an advantage. 


\section{Chapter 8: The Electric Power Industry}

Tomáš Vlček

\subsection{The Electricity Grid of the Czech Republic}

According to the Grid Code, the power system (distribution, transmission) is "interconnected equipment for the generation, transmission, transformation and distribution of electricity including electrical connection and direct lines, measurement systems, protection, control, safety, information and telecommunications" (see ČEPS, a. s., 2011, p. 35). The power system consists of several parts, specifically electricity producing facilities, electricity stations, electricity grids and electricity supply lines. Electricity producing facilities are power plants, meaning the places serving for the transformation of any kind of energy into electric energy. Electricity stations are a set of buildings and equipment at the nodes of the power system. They enable transformation or distribution of the same voltage levels in several directions, transformation of alternating current to direct or vice versa, occasionally also providing the transformation of alternating current into current of different frequency or compensation of a blind current. Electricity grids are sets of interconnected electricity stations and electricity supply lines aimed at the transmission and distribution of electric power. They are divided into transmission grids (transmission system) for remote distribution at the levels of $220 \mathrm{kV}$ and $400 \mathrm{kV}$ and distribution grids (distribution system) for distribution from the transmission system to users carrying $110 \mathrm{kV}, 35 \mathrm{kV}$ and $22 \mathrm{kV}$ of voltage. $110 \mathrm{kV}$ grids are sometimes marked as primary, because they can sometimes serve for bringing capacity into the system from power plants with less capacity (for example, hydropower). Industrial grids also belong in this category, with voltage levels of $22 \mathrm{kV}, 10 \mathrm{kV}, 6 \mathrm{kV}$ and $0.4 \mathrm{kV}$. Grids bringing power directly to the consumption site are marked as local, ranging at the voltage level of $0.4 \mathrm{kV}$. Electricity supply lines are the basic items of the grid, connecting its two points, made of a set of conductors, insulation and structures for mechanical reinforcement. The basic division differentiates exterior supply lines, i.e. uncovered lines on pylons with insulators and cable supply lines, placed into the ground, passages or on pylons (according to "Elektroenergetika I," n.d., p. 2).

There are several types of power station in the Czech Republic. These are steam, water, nuclear, combined cycle, gas, solar, wind and geothermal. Table 8.1 displays installed capacity across these power plants in the Czech Republic as of December 31, 2012.

\begin{tabular}{|l|c|c|}
\hline Tab. 8.1: Installed Capacity in the Czech Electricity Grid on December, 312012 \\
\hline Type of Power Station & Installed Capacity (MWe) & Percentage ( \%) \\
\hline Thermal & 10,644 & 51.9 \\
\hline Gas Combined Cycle & 521 & 2.5 \\
\hline Gas Fired & 750 & 3.7 \\
\hline Hydroelectric & 1,069 & 5.2 \\
\hline Pumped-storage Hydroelectric & 1,147 & 5.6 \\
\hline Nuclear & 4,040 & 19.7 \\
\hline Wind & 263 & 1.3 \\
\hline Solar & 2,086 & 10.2 \\
\hline Geothermal Power & 0 & 0 \\
\hline Total & 20,520 & 100 \\
\hline Source: Energetický regulační úřad, 2013, p. 11. \\
\hline
\end{tabular}


Installed capacity provides little information about the consumption of electric power. Table 8.2 displays gross electricity consumption in the Czech Republic recorded in 2012. In terms of electricity production, power plants are divided into base load and peak load. Base load, i.e. the elemental load of the power system, is the provision of the uninterrupted daily electricity consumption. Based on the nature of operational processes, base load is predominately covered by nuclear and steam power plants whose operating regulation possibilities are limited (mainly nuclear power plants, see below). Peak load is load on the power system exceeding the standard level, supported by power plants which can quickly connect to the grid - mainly pumped-storage hydroelectricity, gas, combined cycle and some steam power plants. There is a vast number of peaks in the course of one year, mainly depending on weather, season of the year as well as time of the day. For example, two peaks emerge every day (mainly on working days), specifically one between $5 \mathrm{AM}$ and $8 \mathrm{AM}$, when people get up and turn on electric appliances, causing a rapid lift of electricity consumption, and a significantly more moderate one between 4 PM and 6 PM, when people return to their homes.

\begin{tabular}{|l|c|c|}
\hline Tab. 8.2: Gross Electricity Production in $\mathbf{2 0 1 2}$ \\
\hline Type of Power Station & Electricity Production (GWh) & Percentage ( \%) \\
\hline Thermal & $47,261.0$ & 53.9 \\
\hline Gas-fired and Gas Combined Cycle & $4,435.1$ & 5.1 \\
\hline Nuclear & $30,324.2$ & 34.6 \\
\hline $\begin{array}{l}\text { Hydroelectricity (incl. Pumped-storage } \\
\text { Hydroelectricity) }\end{array}$ & $2,963.0$ & 3.4 \\
\hline Wind & $4,17.3$ & 0.5 \\
\hline Solar & $2,173.1$ & 2.5 \\
\hline Total gross production & $\mathbf{8 7 , 5 7 3 . 7}$ & $\mathbf{1 0 0}$ \\
\hline Total net production & $\mathbf{8 1 , 0 8 8 . 4}$ & $\mathbf{9 2 . 6} \%$ of gross production \\
\hline Source: Energetický regulační úr̆ad, 2013; percentages by T. Vlček. \\
\hline
\end{tabular}

An electricity station is "a complex of buildings and equipment of the grid serving for the transformation, compensation, conversion or transmission and distribution of electricity, including facilities needed to secure the operation thereof" (see ČEPS, a. s., 2011, p. 42). Electricity stations are functional facilities at the distribution electrical nodes. They are the centre of the majority of distribution system functions, including switching, securing, measuring and control. Substations "serve to change electric voltage at the same frequency and distribution of electricity or to execute galvanic separation of one part of the network from another", switching stations serve to "distribute electricity at the same voltage without transformation and converting", converter stations serve to "convert type of voltage or its frequency" while compensation stations serve to "counterbalance reactive segments in the alternating current or line parameters" (see "Elektroenergetika," p. 5). Electricity stations are divided into stations with less than 1 $\mathrm{kV} \mathrm{AC} \mathrm{(alternating} \mathrm{current)} \mathrm{and} \mathrm{with} \mathrm{more} \mathrm{than} 1 \mathrm{kV} \mathrm{AC.}$

Electricity supply lines represent "the important component of every system, enabling remote transmission of electric energy and signals. Electricity supply lines are made of conductors, which serve to pipe electrical current, and insulation separating the live part from the surroundings (excluding naked lines)" (see Vrána \& Kolář, 2000, p. 2). We differentiate between four types of electricity line: naked wire lines (predominantly installed outdoors rather than indoors, such as, for example, trolley lines), tube and bar lines, wire-bridge lines and cable lines (see Vrána \& Kolář, 2000, p. 2). 
As previously indicated, electricity grids are divided into transmission system and distribution system. A transmission system is "[a] mutually interconnected system of $400 \mathrm{kV}$ and $220 \mathrm{kV}$ lines and equipment and selected $110 \mathrm{kV}$ lines and equipment (see appendix in part VII of the Grid Code) serving for the transmission of electricity throughout the Czech Republic and interconnected with the power systems of neighbouring countries and including protection, measurement, monitoring, safety, information and telecommunications systems" (see ČEPS, a. s., 2011, p. 40). A Distribution system is a "mutually connected set of lines and equipment with voltage levels of 0.4 to $110 \mathrm{kV}$ (with the exception of selected 110kV lines which are part of the transmission system), providing the distribution of electricity in a specified area of the Czech Republic; responsible for measurement systems, protection, monitoring, safety, information and telecommunications" (see ČEPS, a. s., 2011, p. 35). Transmission and distribution systems are organized and operated in the public interest, which is in line with the Energy Act.

The transmission system in the Czech Republic is operated by CEPS, a. s., founded in 1998 by separation of the Transmission System Department from CEZ (and merger with the dissolving company ENIT, a. s.) CEPS is the holder of an exclusive license for electricity transmission. Since September 29, 2009, the Ministry of Industry and Trade has been majority shareholder of the company with an $85 \%$ stake. The holder of remaining $15 \%$ of stocks is the Ministry of Labour and Social Affairs. The exercise of shareholder rights is state-commissioned to the Ministry of Industry and Trade (see ČEPS, a. s., n.d.; ČEPS, a. s., 2010d, p. 18-19).

The transmission system with voltage levels of $400 \mathrm{kV}$ and $220 \mathrm{kV}$ owned by CEPS serves for transmission of electricity for the Czech Republic as well as for the European electricity market. The Czech Republic is by means of cross-border lines connected to the systems of all neighbouring countries, thereby cooperating with the whole electric power system of continental Europe in a synchronized manner (see ČEPS, a. s., 2010d, p. 44). The CEPS transmission system is a set of 38 distribution devices with voltage levels of $420 \mathrm{kV}$ and $245 \mathrm{kV}$ placed inside 30 substations, furthermore encompassing $2,979 \mathrm{~km}$ of $400 \mathrm{kV}$ lines and $1,371 \mathrm{~km}$ of $220 \mathrm{kV}$ lines. Another $123 \mathrm{kV}$ distribution point and $56 \mathrm{~km}$ of $110 \mathrm{kV}$ lines are also a component of the transmission system (see ČEPS, a. s., 2010b).

Distribution systems serve to distribute electric power from a source (the superordinate system or the local power plant) to appliances. Voltage of distributed electricity in the public distribution point ranges at the levels of $110 \mathrm{kV}, 22 \mathrm{kV}$ and $0.4 \mathrm{kV}$, whereas these different voltage networks are separated from each other by substations, in which voltage is transformed (see "Elektroenergetika," p. 3). In the case of distribution of electricity at the same voltage, transformation is not necessary and the distribution proceeds through switching stations.

There are three companies operating distribution systems in the Czech Republic, namely CEZ Distribuce, a daughter company of CEZ., then E.ON Distribuce, a daughter company of E.ON Czech Holding VwGmbH and, finally, PREdistribuce, a. s., a daughter company of Pražska energetika, a. s. These companies are marked as the regional operators of distribution systems (RPDS).

In addition to the regional distribution systems (RDS), there are in the Czech Republic also local distribution systems (LDS), while the term itself is not embodied in any legal act. Local distribution systems are subordinated to the regional ones, providing that the regional operators deliver electricity supplies to the local operators. Local distribution systems are not directly connected to the transmission system. They are connected to the particular regional system and run based on license provisions. There are rather large local distribution systems both in terms of space and consumption or production of electricity, usually located at areas of former industrial agglomerations, such as mines, still mills, large industrial facilities. There are, naturally, also very small local distribution systems (see Chemišinec, Marvan, Nečesaný, Sýkora \& Tůma, 2010, p. 30). 


\subsection{The Regulatory and Safety Framework of the Electric Power Industry}

\subsubsection{State Regulatory Framework}

According to The Energy Act, the exercise of public administration in the energy sectors and, therefore, in the electric power industry, falls under the responsibility of the Ministry of Industry and Trade, Energy Regulatory Office and State Energy Inspection Board. Next to these primary regulatory bodies, we should, add the Czech electricity and gas market operator (OTE), and from the technical perspective, CEPS and the Czech Office for Standards, Metrology and Testing (UNMZ).

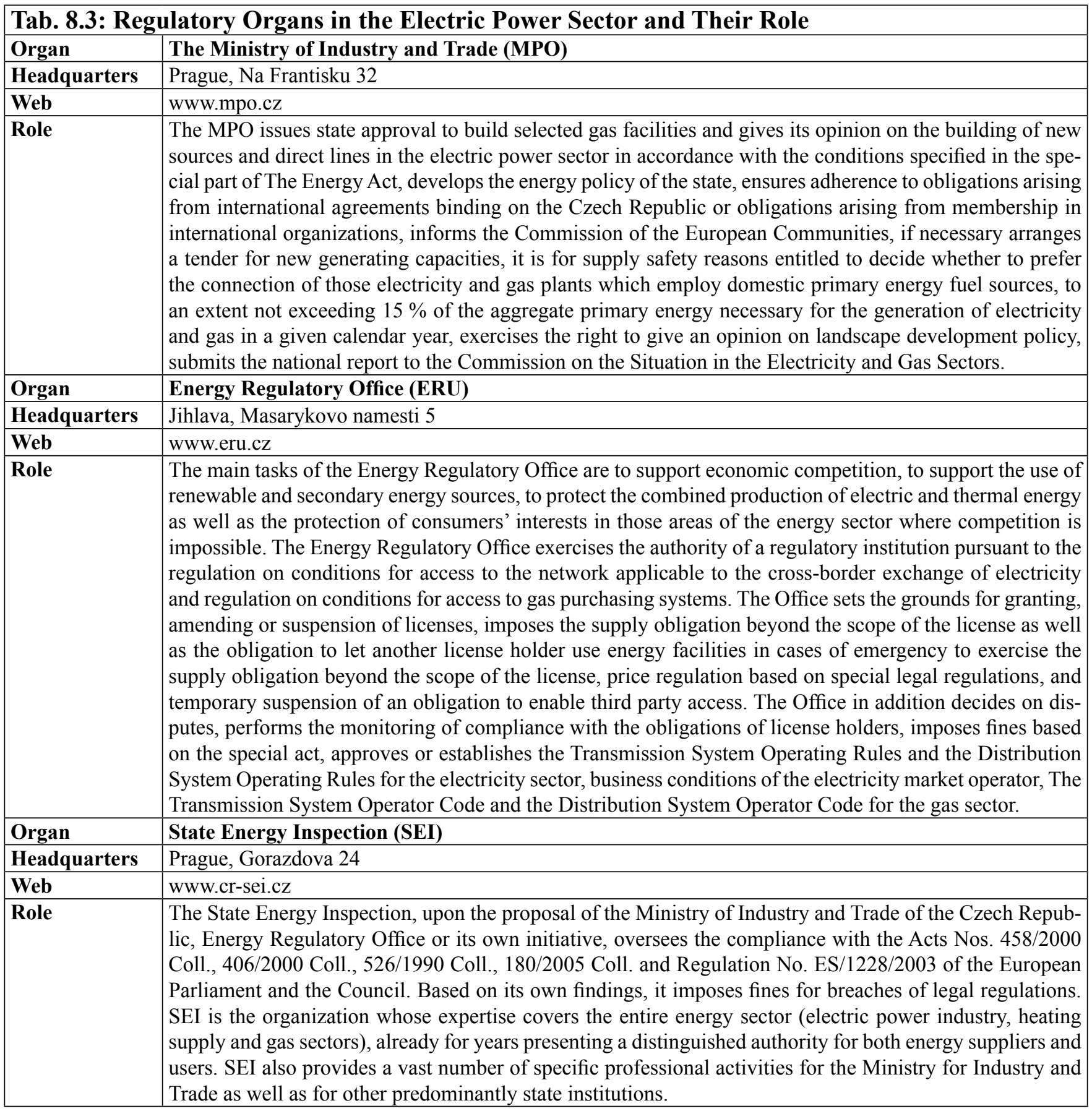




\begin{tabular}{|c|c|}
\hline Organ & The Czech Electricity and Gas Market Operator (OTE) \\
\hline Headquarters & Prague, Sokolovska 192/79 \\
\hline Web & www.ote-cr.cz \\
\hline Role & $\begin{array}{l}\text { OTE among other responsibilities organizes the short-term electricity and short-term gas markets in coop- } \\
\text { eration with the transmission system operator, also organization of the regulating energy balancing market, } \\
\text { evaluation of imbalances within the whole territory of the Czech Republic and ensures their accounting, } \\
\text { preparation of documents for draft Electricity Market Rules and Gas Market Rules, drafts and, following } \\
\text { the approval of the Energy Regulatory Office, releases the market operator's business terms for the power } \\
\text { and gas sectors with remote access, and it administers the National Register of Greenhouse Gas Emissions. }\end{array}$ \\
\hline Organ & CEPS, a. s. \\
\hline Headquarters & Prague, Elektrarenska 774/2 \\
\hline Web & www.ceps.cz \\
\hline Role & $\begin{array}{l}\text { CEPS, a. s. is the company with an inherent monopoly in the field of electricity transmission. It is regulated } \\
\text { by the above-mentioned bodies and accordingly on the basis of The Energy Act regulates technical aspects } \\
\text { of the power system by means of the Grid Code. In this document the company has also embedded the } \\
\text { principles of the scope of its authority as a transmission system operator. }\end{array}$ \\
\hline Organ & Czech Office for Standards, Metrology and Testing (UNMZ) \\
\hline Headquarters & Prague, Gorazdova 24 \\
\hline Web & www.unmz.cz \\
\hline Role & $\begin{array}{l}\text { The main mission of the Office is to perform tasks arising from Czech legislation on technical standard- } \\
\text { ization, metrology and testing and tasks related to the harmonization of Czech technical regulations and } \\
\text { standards with the technical regulations of the European Union. Since 2009, the Office has been ensuring } \\
\text { development and publication of Czech standards. }\end{array}$ \\
\hline
\end{tabular}

Source: Zákon 458/2000; Česká republika - Státní energetická inspekce; Energetický regulační úřad; ČEPS, a. S.; OTE, a. s.; Úrad pro technickou normalizaci, metrologii a státní zkušebnictví; composed by T. Vlček.

\subsubsection{Supranational Regulatory Framework}

The first EU Directive whose implementation was requested as part of the harmonization of the Czech legal framework with the legal framework of the European Community was Directive 96/92/EC (see “Directive 96/92/EC," 1997, p. 0020-0029) from December 19, 1996, referring to electricity market liberalization. The directive has become a part of the Czech legal system by its implementation into Act No. 458/2000 Coll. This directive was the first to define unbundling, i.e. separation of electricity trading from the trade in its transmission and distribution. Chapter VI established the unbundling of accounts, i.e. keeping the separate production, transmission and distribution accounts within energy companies.

Directive 96/92/EC was replaced by Directive 2003/54/EC of the European Parliament and the Council (see "Directive 2003/54/EC," 2003) from June 26, 2003, concerning common rules for the internal market in electricity and repealing Directive 96/92/EC, requesting an even higher degree of market openness. The idea behind this request was to hasten the liberalization process. This document set an obligation to separate energy activities first at the managerial level, followed by the legal division of electricity companies (so-called legal unbundling) into two entities (transmission traders and electricity traders). The directive even shortened the deadlines for market opening. The member states on these bases had to separate transmission networks from the generation and sale of electricity, specifically either through the means of ownership unbundling (i.e. emergence of new companies trading in electricity transmission) or as an independent system operator - ISO (meaning that the transmission network would remain in a company's ownership, however, after previous approval by the European Commission). 
Directive 2009/72/ES of the European Parliament and the Council from July 13, 2009, concerning common rules for the internal market in electricity and repealing Directive 2003/54/EC entitles users to change electricity supplier, free of charge and within a three-week period, or to receive reimbursement from an energy company. The undertaking of operators of electricity markets was broadened so as to also include the gas sector (see OTE, a. s., 2010a, p. 8-9).

\begin{tabular}{|l|l|}
\hline Tab. 8.4: The Process of Electricity Market Liberalisation in the Czech Republic \\
\hline Stage & Eligible customers \\
\hline From 1/1/2002 & Customers whose yearly electricity use exceeds $40 \mathrm{GWh}$ (eligible customers) are entitled to choose a supplier. \\
\hline From 1/1/2005 & Customers whose yearly electricity use exceeds $9 \mathrm{GWh}$ are entitled to choose a supplier. \\
\hline From 1/1/2005 & Customers whose yearly electricity use exceeds $100 \mathrm{MWh}$ are entitled to choose a supplier. \\
\hline From 1/1/2006 & All customers (end users) are entitled to choose a supplier. \\
\hline \multicolumn{2}{|l|}{ Source: Müller, 2002, p. 53-55; Energetický regulační úrad, 2011c. } \\
\hline
\end{tabular}

The formation of a single electricity market was generally criticized, because it was, according to many, unnatural. Generation, transmission and distribution systems did not emerge as independent units, but had, on the contrary, experienced interconnected and joint development. A monopolistic position of the entire electricity sector is, therefore natural. A natural monopoly ${ }^{170}$ applies only to grids (electricity transmission and distribution systems) and system dispatchers (unbundled from the producing system). M. Piha, however, for example, thinks that production also falls under the category of a natural monopoly. It is, according to him, absurd to "have production, (whose integration gave an incentive to the emergence of the transmission system) and system dispatcher that gave birth to the monopoly, denied natural monopoly character and be, on the contrary, recognized for activities (of transmission and dispatching) which were caused by this integration as auxiliary mediums. For the producing system to be competitive, it should be split into several independent producing entities, or (a) to find further independent producers and suppliers of electricity, and in that manner create more producing entities which would compete in supplies for the transmission system, which would, in turn, employ this competition through its system dispatcher" (see Píha, 1994, p. 69). Based on this thinking, we could, for example, argue that the most frequently criticized position of CEZ in the field of electricity production in the Czech Republic, which shows some monopolistic features, is basically a reflection of the development which the Czech electric power sector has seen throughout its history.

M. Kubin, on the other hand, understands a natural monopoly (in the mid-term horizon) only in terms of transmission and distribution of electricity, because "in the chain production - transmission - distribution - consumption, a combined cycle, pressurized fluid combustion or the new generation of nuclear reactors meeting safety and environmental requirements represent a fierce competitive setting for production, while the competitive setting has been arising also at the level of final consumption" (see Kubín, 2009, p. 238).

Almost 20 years later, we can say that the strong position of CEZ is still prominent $(57.6 \%$ of installed capacity, $73.7 \%$ of gross electricity production and $64.1 \%$ of electricity distribution, see ERÚ, 2010b; ERÚ, 2011a, p. 50), but the electricity market opening up has, however, led to an increase in the

170 A natural monopoly emerges, if a company in a particular region produces and sells its products cheaper, i.e. with fewer costs than the competing company or group of companies, never, however, for power or institutional reasons (see Kubín, 2009, p. 238). 
number of electricity producers and distributors, while the share of other companies on the market is expected to thrive with regard to the increasing interest in renewables. In the long term it therefore seems that competitiveness can be achieved even in a production system with a heavily burdened history, though with certain restrictions.

If we are to at least marginally assess the current position of CEZ in the electricity, respectively energy, sector of the Czech Republic, we should say that its majority stake is held by the state ${ }^{171}$, but it is still a trading company which makes increasing profit its primary objective. The company always seeks to respond to the state energy papers in a flexible manner, whereas the latter are, however, changed and updated too frequently to have the company entirely rely on them. Vaclav Bartuska, Special Envoy for Energy Security of the Czech Republic, has very aptly warned about this situation. "The state does not have a long-term strategy, it does not have its own long-term vision of what it wants to do with CEZ, thereby this company, of course, alone looks for what to build or what to do business with" (see "Otázky Václava Moravce," 2009). Such a company, naturally, requires a strategic plan for decades ahead and it is incapable of functioning in an entirely flexible manner. Its dominant position together with an effort to solely find a clear direction of the Czech energy sector, which cannot be found in state papers changed or updated basically with every incoming government, is, in consequence, often the target of criticism. The company thus noted that the conceptual documents included a rather steady approach to the issue of coal and nuclear use, which also suited it in economic terms, while with regard to the fact that the company would participate in the preparation of these documents, it itself strove to promote this steady path as well. This was also one of the incentives for opening the discussion on environmental mining limits, the incentive for some foreign CEZ acquisitions, the incentive for retrofitting of coal power plants, preparation and call for tender for the new Temelin nuclear blocks, cooperation with Serbia and Slovenia in the future construction and operation of new nuclear blocks, etc. Simply put, CEZ does business where it sees longterm and more consistent prospects. The demonizing of this company by the media has not always been justified (see Černoch, Zapletalová, \& Vlček, 2010, p. 276-277).

During the Czech presidency in the Council of the European Union and the European Council in the first half of 2009, in June 2009, the Third Energy Liberalization Package was adopted (Directive 714/2009/ EC). The Package came to harmonize the authorities and responsibilities of the given regulatory agencies, while requesting their complete independence (i.e. unbinding of a regulatory fund from the rest of the state money). In the Czech Republic, this body was the Energy Regulatory Office. Regulatory agencies are supposed to be overseen by the Agency for the Cooperation on Energy Regulators (ACER) controlled by the European Parliament. ${ }^{172}$ The transmission grid operators are supposed to harmonize their activities and coordinate at EU level through the organization ENTSO-E (European Network of Transmission System Operators for Electricity) (see "Třetí liberalizačni," 2009). ENTSO-E currently brings together 41 system operators (TSO) from 34 countries. The previous associations of system operators in Europe were with the emergence of ENTSO-E dissolved (thus the previous CENTREL and UCTE as well). ENTSO-E's vision is to become the focal point of all European technical, business and political aspects of system operators' functioning. ENTSO-E wishes to create pan-European electricity trading based on cooperation, safety of supplies, safe integration of renewable energy sources and reliable modern networks (see The European Network of Transmission System Operators for Electricity).

171 The ownership structure as of December 31, 2009, is as follows: The Ministry of Finance of the Czech Republic - 69.369 \%, other legal persons $-4.427 \%$, natural persons $-5.416 \%$, administrators, total $-20.788 \%$ (see ČEZ, a. s., 2010 b). 
Liberalization of the electricity market led to a significant multiplication of new electricity traders. As of 2011, there have been in the Czech Republic 37 suppliers, with more than 100 consumption and connection sites, and a total of 64 entities taking part at the OTE platform. The market has truly experienced a massive response, since by January 2012 the Czech Republic numbered already 1,105,274 low and high energy users who had changed their electricity suppliers (see OTE, a. s.).

\begin{tabular}{|c|c|c|c|c|c|c|c|c|c|}
\hline 2003 & 2004 & 2005 & 2006 & 2007 & 2008 & 2009 & 2010 & 2011 & 2012 \\
\hline 16 & 399 & 3,511 & 13,150 & 46,016 & 57,689 & 96,744 & 249,181 & 448,860 & 272,148 \\
\hline
\end{tabular}

The largest alternative electricity suppliers as of April 2011 were Bohemia Energy Entity, s. r. o. (165,556 users); Centropol Energy, a. s., (150,432); Bicorn, s. r. o. (42,097); Ceske Energeticke Centrum, a. s., $(19,294)$ and United Energy Trading, a. s., $(8,425)$ (see OTE, a. s.).

What this sort of company has in common is their similar manner of reaching their potential users. They have door-to-door salesmen who offer the product and services directly at users' homes, while the present market is characteristic in that it hosts a clash of previous large distributors (mainly CEZ Distribuce and E.ON Distribuce) and the companies Bohemia Energy Entity, s. r. o. and Centropol Energy, a. s.

Large distributers are filing complaints with the Energy Regulatory Office and State Energy Inspection Board, referring to the unfair business of new electricity traders or their coercive persuasion of customers; new traders are filing similar complaints over counter-enticing of customers and limitation of market competition. A lot of complaints, launched by both parties, are based on truth.

We should accept this state of affairs as a modern and, accordingly, future trend, triggered by the liberalization of the electricity market. It hits against the centralized electricity sector built and historically settled for decades, founded on the principle of centralized large power plants and complex distribution grids. We can, therefore, expect that the transition to the modern decentralized system embracing small production units, numerous electricity traders and suppliers to end users, with a great share of electricity from renewable, to the system directed by consumption and relatively less by production, will for these reasons proceed at a notably slower pace than was the case, for example, in neighbouring Germany.

\subsection{The Transmission and Regulation of Electricity}

The power system is a dynamic, permanently active system, changing every second. The majority of producing facilities and appliances are nowadays optimised at a frequency of $50 \mathrm{~Hz}$. "This frequency in the grid means that produced active power (which equals the total of all active power of producing generators within the whole system) equals consumed power (the total of inputs of all appliances and losses in grids)" (see Šolc, 2008b, p. 50). A state of balanced electricity supply and its off-take is the optimum condition in the grid as well as the mandatory one, should the power system remain stable. 
Change of both demand and supply scales is a logical order of events, where these changes must be immediately reflected at the supply, respectively demand level, or else there is a risk of overvoltage or undervoltage, which can shortly after lead to the collapse of the power system and brownouts ${ }^{173}$ or blackouts $^{174}$ or island operation ${ }^{175}$. At the point when consumption (respectively demand) rises, there is a shortage at the level of production (i.e. supply), resulting in an immediate drop of frequency and, consequently, a drop of voltage. In order to maintain frequency, an immediate producing reaction must follow in order to increase the volume of produced power. Likewise, should consumption drop and production not respond to this situation, respectively, should production increase without considering the actual consumption, it would result in an increase in frequency and, consequently, overvoltage of the grid. Such a situation must be rapidly regulated through attenuating or disconnection of power plant production. Regulation power is not used for regulation of electricity from renewables only, although its use has significantly increased with respect to Act No. 180/2005 Coll., on the promotion of electricity production from renewable energy sources and amending certain acts, which adds to the previous obligation of electricity purchase to all licensed third parties within the meaning of The Energy Act No. 458/2000 Coll. an obligation of preferential purchase of electricity from renewables to all licensed third parties (TPA), provided that they have a license issued by the Energy Regulatory Office.

The reasons behind the above-mentioned situations vary, starting from planned and unplanned decommissioning of producing blocks, unexpected damaging of transformers, networks or distribution lines, weather impacts (for example, snowdrifts, sharp drops in outdoor temperatures, etc.) through to really drastic changes in electricity production from renewables (i.e. from wind and solar power plants). The cross-border interconnection of systems contributes to the safety of the power system because the larger the system the harder it is to significantly affect its frequency by increasing or decreasing consumption or production in some of its parts.

Different types of power plant have a different capability of drastic reduction or increase in capacity. For example, the Czech nuclear power plants can in a relatively flexible manner change their capacity up to approximately $10 \%$ of installed capacity. ${ }^{176}$ Regulation above $10 \%$ would require a major intervention in production, which would manifest at the point necessary to return to the previous capacity level, ranging with accordance to the demanded regular interruption for tens of hours, days or even weeks. Power plants powered by water (pumped-storage hydroelectricity, hydropower plants) are, in turn, capable of connection or disconnection in couple of seconds up to tens of seconds ${ }^{177}$, while power plants powered by gas (combined cycle, gas and fuel-fired) reach this efficiency within tens of seconds up to minutes. Following the regulation of capacity, the Czech Republic has built a grid of reserve and regulatory sources which are joined into the power system services.

173 A brownout is a partial outage or larger forced interruption or limited electricity supply within a larger area.

174 A blackout is a total or larger outage of electricity as a result of grid failure.

175 Island operation is a disconnection of a part of the grid and its operation as an independent system. The quality of supplies is usually significantly worse and unstable.

176 The Temelin nuclear power plant, therefore, up to 100 MWe per block, i.e. $200 \mathrm{MWe}$, Dukovany up to 80 MWe per block, i.e. 320 MWe (see ČEPS, a. s., 2010d, p. 20). The Temelin nuclear power plant is in reality, however, as a result of technical limitations, capable of regulation at the level of $+/-5 \%$, while the Dukovany nuclear power plant undergoes regulation only exceptionally.

177 For example, the Dlouhe Strane power plant is capable of moving from sleep mode to full capacity in 100 seconds. 
In the Czech Republic, CEPS is by law the entitled regulator of the power system, and is the coordinator and provider of the aforementioned system services. System services predominantly ensure regulation reserves and stability of transmission, ensuring adequate voltage levels and restoration following a total or partial system blackout ${ }^{178}$. In terms of network stability during the balancing of electricity supplies and consumption, regulation reserves are a key feature, in more details displayed in table No. 8.6.

\begin{tabular}{|l|l|l|l|}
\hline \multicolumn{2}{|l|}{ Tab. 8.6: A Simplified Division of Regulation Reserves as part of CEPS System Services } \\
\hline System Service & Mark & $\begin{array}{l}\text { Time Frame- } \\
\text { work }\end{array}$ & Description \\
\hline Regulation Reserve Seconds & RZV & 30 seconds & It serves for the primary regulation (RZPR) \\
\hline $\begin{array}{l}\text { Positive Minute Reserve available with- } \\
\text { in 5 minutes }\end{array}$ & RZ5+ & 5 minutes & $\begin{array}{l}\text { Positive minute reserve available within 5 minutes } \\
\text { (RZMZ5) }\end{array}$ \\
\hline $\begin{array}{l}\text { Regulation Reserve available within 15 } \\
\text { minutes }\end{array}$ & RZ15 & 15 minutes & $\begin{array}{l}\text { It serves for secondary regulation, it consists of } \\
\text { sources starting as positive or negative in a rapid } \\
\text { manner, available within (RZSR, RZ15+, RZ15-) }\end{array}$ \\
\hline $\begin{array}{l}\text { Positive Minute Reserve available with- } \\
\text { in 30 minutes }\end{array}$ & RZ30+ & 30 minutes & $\begin{array}{l}\text { It serves for tertiary positive regulation, it consists } \\
\text { of dispatch reserve, emergency exchange and regula- } \\
\text { tion reserve from abroad, all available within 30 min- } \\
\text { utes (RZMZ30+, EregZ30+, EregZG30+, Ereg30+) }\end{array}$ \\
\hline $\begin{array}{l}\text { Negative Minute Reserve available with- } \\
\text { in 30 minutes }\end{array}$ & RZ30- & 30 minutes & $\begin{array}{l}\text { It serves for tertiary negative regulation, it consists } \\
\text { of regulation reserve for power reduction, dispatch } \\
\text { reserve, emergency exchange and regulation re- } \\
\text { serve from abroad, all available within 30 minutes } \\
\text { (RZSV30+, EregZ30-, EregZG30-, Ereg30-) }\end{array}$ \\
\hline $\begin{array}{l}\text { Regulation Reserve (Non-Rotary) avail- } \\
\text { able in over 30 minutes }\end{array}$ & RZN>30 & $\begin{array}{l}\text { Over } 30 \quad \text { min- } \\
\text { utes }\end{array}$ & $\begin{array}{l}\text { It consists of dispatch reserve, regulation energy } \\
\text { and regulation energy from abroad, all available in } \\
\text { over 30 minutes (Ereg }>30+, \text { Ereg }>30-, \text { EregZ }>30+, \\
\text { Ereg }>30-\text { ) }\end{array}$ \\
\hline
\end{tabular}

Note: a positive reserve means an increase in capacity, while a negative reserve means an increase in consumption. RZSV $=$ regulation reserve for power reduction.

Source: ČEPS, a. s., 2013, p. 4.P3; modified by T. Vlček.

Table No. 8.7 shows the maximum regulation reserves recorded in 2013. If installed capacity of the Czech power system was as of December 31, 2012, at a level of 20,520 MW (see table No. 8.1) and total daily regulation during the working days at a level of 1,585 MW (night regulation 1,395 MW), the potential of regulation capacities is, therefore, $7.72 \%$ of installed capacity. In the case of the regulation of electricity from renewables (a total of $2,349 \mathrm{MW}$ ), then it is $67.48 \%$ of installed capacity. In terms of the provision of a stable network within the scope of currently installed capacities, we hereby speak about a satisfactory situation ${ }^{179}$, however, with regard to the numerous of approved applications of photovoltaic power plants to connect to the network, ensuring additional reserves will require significant investment (for more detail, see below).

178 It is the capability of island operation or the capability of a black start (capability of running the blocks without the support of an external voltage source, capability of reaching the given voltage, possibility of connecting to the network and its running in island operation mode).

179 When renewables are involved, it is necessary to pay attention to the real potential of electricity generation and never to installed capacity. For example, in the research carried out by Liberalni institute, o.s. Negative Impact of Network Industries Regulation and the Change of Regulatory Framework in 2006 it turned out that wind power plants would in the Czech Republic for $40 \%$ of the operating period supply less than $4 \%$ of installed capacity, while at least a half of installed capacity can be expected only during $7 \%$ of the period (see Ryvolová, 2006, p. 23). 


\begin{tabular}{|c|c|c|c|c|c|c|c|c|c|c|}
\hline Tab. 8.7: Maximum Regulation Reserves in the Czech Republic in 2013 \\
\hline & \multicolumn{2}{|c|}{ RZV } & \multicolumn{4}{c|}{ RZ10, RZ15 } & \multicolumn{2}{c|}{ RZ15, RZ30 } & \multicolumn{2}{c|}{ RZ15- } \\
\cline { 2 - 11 } & \multicolumn{2}{|c|}{ RZPR } & \multicolumn{2}{c|}{ RZSR } & \multicolumn{2}{c|}{ MZ5+ } & \multicolumn{2}{c|}{ MZ15+, MZ30+ } & \multicolumn{2}{c|}{ MZ15- } \\
\cline { 2 - 11 } & Night & Day & Night & Day & Night & Day & Night & Day & Night & Day \\
\hline Working days & 85 & 85 & $280-290$ & 350 & 550 & 550 & $230-240$ & 330 & $220-230$ & 270 \\
\hline $\begin{array}{c}\text { Non-working } \\
\text { days }\end{array}$ & 85 & 85 & $280-290$ & 350 & 550 & 550 & $220-230$ & 310 & $230-240$ & 280 \\
\hline
\end{tabular}

Note: All data indicated in MW; RZPR: Primary Regulation Reserve; RZSR: Secondary Regulation Reserve; QS10: Quick Start 10 Minute Reserve; RZTR+: Tertiary Positive Regulation Reserve; RZTR-: Tertiary Negative Regulation Reserve; RZN+: Regulatory Positive Reserve (Non-Rotary) available within 30 minutes; RZN-: Regulatory Negative Reserve (Non-Rotary) available within 30 minutes.

Source: ČEPS, a. s., 2013, p. 4.P4-4.P5. Modified by T. Vlček.

System services are ensured by means of ancillary services $(\mathrm{PpS})$, which are purchased on the special market, Day-Ahead Ancillary Services Market (DT PpS), which has functioned since October 1, 2001, and it is organized by OTE. CEPS buys these services from the electricity producers in the Czech Republic. Approximately $90 \%$ of $\mathrm{PpS}$ is purchased on long-term contract bases, while the remaining $10 \%$ is provided through the means of the Day-Ahead Market.

With regard to the necessary rapidity of connection of reserve sources, pumped-storage hydroelectricity, gas and combined cycle and some steam power plants are important. CEPS purchases more than $50 \%$ of ancillary services from the CEZ Group. System services are paid by all users of those services, i.e. by end users, producers connected to the power system and to a certain extent also by users within island systems. Money from the ancillary services is then delivered to CEPS through the regional distribution operators and producers. The price is regulated and it is decided by the Energy Regulatory Office on a daily basis (see ČEPS, a. s., 2010a).

CEPS in that manner also takes care of covering the losses within the distribution system and, based on its own predictions, purchases electricity to cover the losses at tenders for single products and at the special short-term electricity market organized by OTE (see ČEPS, a. s., 2010a).

\subsection{The Price of Electricity and the Trade in Electricity}

The final price of electricity supplies on the liberalized market is for the eligible customers composed of regulated prices of activities that are of a natural monopolistic character, i.e. activities associated with the transmission of electricity to a producer via transmission and distribution systems to an end user. This regulation is performed by the Energy Regulatory Office, which on a regular basis issues a Price Decision. The provision of a stable electric power system in technical and business terms has its own impact on the price. The second substantial component of the final electricity price is the price of electrical energy itself which is set by suppliers (producers and traders) themselves along single customer categories and it is a contractual matter. This part of the price is not regulated by the Energy Regulatory Office (see Energetický regulačni úrad).

The final price of electricity supplies is for all categories of end user composed of five basic elements. The first element of price is the unregulated price of the commodity, i.e. electrical energy the price of which is set in line with market principles and in accordance with the trading strategies of single electricity 
suppliers. Other price elements encompass regulated activities of a monopolistic character, among these transmission of electricity from the producing facility via transmission and distribution systems to an end user, and furthermore, activities tied to ensuring a stable energy system in technical (the provision of system services) and business terms (mainly the activity of an electricity market operator in the field of imbalances' accounting). The last element of the final price of electricity supplies is then a contribution to the promotion of electricity from renewables, combined generation of electricity and heat and secondary sources. In this manner, the price of electricity supply is being set for all customer categories, in effect from January 1, 2006, when Czech electricity was entirely liberalized (see ERÚ, 2009c, p. 2; Dufková, 2005, p. 2).

\begin{tabular}{|c|c|}
\hline \multicolumn{2}{|c|}{$\begin{array}{l}\text { Tab. 8.8: Share of Single Components of the Price of Electricity Supplies to Households in } 2010 \\
\text { (including VAT) }\end{array}$} \\
\hline Electrical energy including a trading margin & $42.27 \%$ \\
\hline Market operator & $0.12 \%$ \\
\hline CEPS system services & $3.94 \%$ \\
\hline Renewables and cogeneration & $4.22 \%$ \\
\hline Decentralized production & $0.19 \%$ \\
\hline Electricity transmission & $2.86 \%$ \\
\hline Electricity distribution & $29.00 \%$ \\
\hline Environmental tax & $0.72 \%$ \\
\hline VAT & $16.67 \%$ \\
\hline
\end{tabular}

In terms of stock market standards, trading in electrical energy proves to be very specific. For physical laws, the trade proceeds in real time and under the conditions of balanced supply and demand in the power system. This means that the volume of a demand in MWh must be equal to the volume of supply in $\mathrm{MWh}$, otherwise, the regulation reserve for covering fluctuations in the power system enters into play.

Trade with electricity in the Czech Republic takes place at the level of Power Exchange Central Europe, a. s., (PXE), initiated in March 5, 2007, as the Prague Energy Exchange, while a daily market has taken place since April 1, 2009, exclusively on the OTE platform. On September 1, 2009, OTE has with the Slovakian Power System (SEPS) started up trading at the joint daily electricity market as part of the Market coupling CR-SR framework (see OTE, a. s., 2010b, p. 12).

Trading on the platform was launched on July 17, 2008, and on July 1, 2009, the platform changed its name to PXE and transformed into a joint stock company. The PXE Exchange facilitates the trade in electric power with the places of supply located in the Czech Republic, Slovakia and Hungary, while it is as a daughter company of the Prague Stock Exchange, moreover, a part of the CEE Stock Exchange Group, which brings together four Central European stock exchange markets: Vienna Stock Exchange (Wiener Börse), Budapest Stock Exchange (Budapesti Értéktőzsde), Ljubljana Stock Exchange (Ljubljanska borza) and the Prague Stock Exchange.

Trading within the PXE framework can be performed only by actors meeting the requirements of the Exchange in line with applicable legal regulations, Exchange Rules, Exchange Regulations and Rules of Clearing (see Power Exchange Central Europe, a. s., 2010, p. 4). Then they have to possess a license for 
electricity trading (for foreign actors issued by their home institutions) ${ }^{180}$, to be the subject of clearance at their own transmission system operator ${ }^{181}$ and to have an agreement closed with a clearing bank. ${ }^{182} \mathrm{~A}$ trading participant is, moreover, obliged to purchase electricity only for resale purposes and will not be its end user (see Power Exchange Central Europe, a. s., 2011a, p. 8). Even though the participants' names are publically disclosed, the trading itself proceeds anonymously. Trading is regulated, the currency is EUR, while closed trades are guaranteed and cannot be cancelled.

Physical settlement is based on "the obligation of both parties to the trade to deliver/pay for a certain volume of MWh in a given future delivery period and for an agreed price." Financial settlement is based on "the obligation of both parties to the trade to provide future financial settlement of the price differences regarding the subject of the trade, during the delivery period” (see Burza cenných papírů Praha, a. s., 2011, p. 35).

According to the length of the period of delivery of the agreed volume of electricity, the individual contract trades at the PXE are hourly, daily, monthly, quarterly or annual. Furthermore, contracts are divided into two basic groups according to whether the electricity supply should take place at all hours of all days of the distribution period (the base load) or only between Monday and Friday and between 8 AM and 8 PM (the peak load), where state holidays, respectively days off are considered work days. ${ }^{183}$ Finally, contracts are divided into futures (i.e. annual, quarterly and monthly base loads and peak loads) and SPOT ${ }^{184}$ (i.e. daily and hour peak loads and base loads).

The result is the nine basic products which are the subject of PXE trade. Electrical energy is then supplied at the constant value of an hourly output of $1 \mathrm{MW}$ at all hours of all days of the agreed period of delivery or consumption. Electricity transmission is not included in the contract price (Burza cenných papírů Praha, a. s., 2011, p. 35; Horová, 2009). Electricity trading at the PXE Exchange also has its limits in terms of order volume (see table No. 8.9) and volume of traded contracts (fixed at the level of $1 \mathrm{MW}$ ).

\begin{tabular}{|l|c|c|}
\hline Tab. 8.9: Minimum and Maximum Volume Orders at PXE Exchange \\
\hline Type of contract & A Minimum Order Volume & A Maximum Order Volume \\
\hline Hourly (H) & $1 \mathrm{MW}$ & Unlimited \\
\hline Daily (D, peak and base) & $1 \mathrm{MW}$ & $50 \mathrm{MW}$ \\
\hline Monthly (M, peak and base) & $10 \mathrm{MW}$ & $25 \mathrm{MW}$ \\
\hline Quarterly (Q, peak and base) & $5 \mathrm{MW}$ & $25 \mathrm{MW}$ \\
\hline Yearly (CAL, peak and base) & $5 \mathrm{MW}$ & $15 \mathrm{MW}$ \\
\hline Source: Power Exchange Central Europe, a. s. Modified by T. Vlček. \\
\hline
\end{tabular}

180 It is the Energy Regulatory Office (ERU) for the Czech Republic, the Regulatory Office for Network Industries (URSO) for the Slovak Republic and the Hungarian Energy and Public Utility Regulatory Authority (MEH) for Hungary.

181 It is OTE, a. s. for the Czech Republic, the Slovak electricity transmission system (SEPS) for the Slovak Republic and the Hungarian Independent Transmission Operator Company (MAVIR) for Hungary.

182 The bank which is in line with the PXE Rules of Clearing responsible for unconditional fulfillment of an obligation resulting from the clearing of an exchange trade performed by a trade participant has a closed agreement with the bank on exchange trade clearing, among others including the bank's obligation to cover trading and clearing fees (see Power Exchange Central Europe, a. s., 2011, p. 5).

183 OTE, a. s., moreover, offers an off-peak load, which is a supply during working days from midnight to $8 \mathrm{AM}$ and from 8 PM to midnight.

184 Single Payment Options Trading. 
A client sets further parameters, such as price and allowed range of price (usually $5 \%$ ) and waits for an adequate counter offer. Market makers (persons who maintain offer and demand levels) quote an offer with a demand at the given range of price and with respect to other circumstances. At the point when demand meets with the best corresponding offer, the auction is paired and closed at the very trade site. Once the contract is signed, further options of use can be additionally modified by the new contracts (usually shorter ones), whereas it is also possible to request only a negative contract, for -10 MW base M05-14, therefore, a reduction of the base load output in May 2014 by $10 \mathrm{MW}$ (i.e. of 13,640 MWh).

After the trade is closed, it is followed by its settlement executed by the Central Securities Depository Prague. The participant's clearing bank is in charge of his or her financial liability, therefore, ensuring financial clearance. In terms of the physical transmission of traded electricity, it is OTE that is responsible for the commodity, receiving information about trading events at the PXE one day ahead and also providing reserve supplies in case of a failure (see Horová, 2009).

\subsection{The Stability and Development of the Transmission System - Current Issues}

Even though a number of current topics in the Czech electric power system have already been addressed in other parts of the text, the phenomenon of stability and development of the transmission system deserves its own space. The stability of the transmission and, hence, of the distribution system is for the field of the electricity sector simply the key factor, both in terms of a balanced level of production and consumption $^{185}$ as well as in a purely technical aspect. Electricity lines and other parts of the power system need to be kept in good condition, which is impossible to achieve without investing in repair, maintenance and developing services. The stability of the transmission network is presently affected by several events, among these the planned completion of the Temelin nuclear power plant, integration of electricity from renewables into the grid as well as the problem of sudden fluctuations in the grid due to electricity from wind power plants in northern Germany, which at points of overvoltage in Germany flow through the Czech Republic. CEPS, as the owner of an exclusive license to run the transmission system, is bound by law to maintain and develop the transmission system.

The Temelin nuclear power plant has 2 x 1,000 MWe of installed capacity. Even though this volume is never sent to the grid in its full capacity, the outgoing clean active power ${ }^{186}$ must be coupled with a sufficiently loaded line. The reactive power of one block in Temelin is $19 \mathrm{MWe}$ (the energy efficiency of one block is therefore $98.1 \%$ ), operational energy spending amounts to $69 \mathrm{MWe}$, while in its full operation capacity it truly adds to the network 2 x 912 MWe of active power (see ČEZ, a. s., n.d.b). Presently there are two V051 and V052 lines of $400 \mathrm{kV}$ connected in the Temelin nuclear power plant, aimed at delivering power to the Kocin substation and for potential supply for consumption of its own producing blocks. The outlet from the Kocin substation counts a total of five lines at the voltage level of $400 \mathrm{kV}$ (V476, V475, V432, V473 a V474) and eleven lines at the voltage level of $110 \mathrm{kV}$ (see ČEPS, a. s., 2009). The trans-

185 Consumption is the amount of energy which an electric appliance draws from the electricity grid in order to function. A colour television, for example, consumes $100 \mathrm{~W} / \mathrm{h}$, a washing machine $500-2200 \mathrm{~W} / \mathrm{h}$, an iron 1,000 W/h, a notebook $40 \mathrm{~W} / \mathrm{h}$, a PC with LCD monitor $80 \mathrm{~W} / \mathrm{h}$, central air conditioning 3,500 W/h, kettles 2,000 W/h, a vacuum cleaner 1,000 W/h, toasters 1,200 $\mathrm{W} / \mathrm{h}$, microwaves $900 \mathrm{~W} / \mathrm{h}$, refrigerators $25 \mathrm{~W} / \mathrm{h}$ and freezers approximately $30 \mathrm{~W} / \mathrm{h}$ (see Šedivý, 2003).

186 The installed capacity is the maximum theoretically possible capacity of a specific system. Reactive power should be excluded from overall installed capacity; since it is power that in reality does not work (it is given by the energy efficiency of a system). Active power is truly achievable power that can be sent to the grid. In the case of power plants, this capacity is further reduced by the electricity necessary for the functioning of the power plant itself. 
mission system in the condition we have had it so far is insufficient for maintaining the additional nuclear plant: "If the tender is won by a project proposing $2 \times 1,200 \mathrm{MWe}$, it will prove necessary to connect the $400 \mathrm{kV}$ Kocin substation with the Mirovka $400 \mathrm{kV}$ distribution point with a double $400 \mathrm{kV}$ line and enhance the connection of the Mirovka $400 \mathrm{kV}$ distribution point to the transmission system by looping the existing Reporyje-Prosenice V413line to this station" (see Cieslar, 2010a, p. 59).

CEPS is obliged to publically release the expected development of the transmission system over the course of a minimum five years. However, as a result of the demanding allocation of investment in infrastructure, CEPS in reality has the plans briefing a 15 years development, not only five (see Vnouček, 2010 , p. 30). Only the system development for enabling the integration of the new nuclear blocks with 1,200 MWe of capacity requires the investment of 8.08 billion CZK by 2020 . Here we cannot but wonder whether the investments associated with the development of the producing portfolio of a private company should be paid by the investor, namely CEZ, and not in any case by end users, especially in regions covered by other companies than CEZ.

Next to investments related to the completion of the Temelin nuclear power plant, CEPS needs to reflect a number of other changes, among which, for example, the construction of a coal-fired block in the Ledvice power plant and the Pocerady combined cycle power plant, modernization of the Prunerov II power plant, decommissioning of two blocks of the Detmarovice power plant and the increasing number of applications for connection of electricity plants employing renewables (aside from the photovoltaic sector, for example, wind parks in Krusna hora and Karlove Vary regions).

The entire situation forces CEPS to invest substantial financial assets for maintenance and sustaining of a stable grid, whereas the Czech Republic should by 2018 invest 24 billion CZK for development of its transmission system, 2 billion per year for restoration of the existing components by 2016, while CEZ Distribuce, a. s. by 2020 intends to invest 130 billion CZK in the distribution system (see Cieslar, 2009). The need to react to changes of the production electricity base and with that associated expenses is, furthermore, complicated also by complex permit procedures for line constructions, which in the Czech Republic last between 7 and 10.5 years (see table No. 8.10).

\begin{tabular}{|l|c|}
\hline Tab. 8.10: The Example of the Construction Process of an Extra High Voltage Line \\
\hline Activity & Duration \\
\hline Feasibility studies, route location and spatial issues & $6-12$ months \\
\hline EIA “Environmental Impact Assessment” Study and public discussions & $12-18$ months \\
\hline $\begin{array}{l}\text { Entry of the routes in the cadastral map (of a local plan), preliminary agreement with } \\
\text { the property owner, preliminary construction project, request and provision of access } \\
\text { to the local plans }\end{array}$ & 12 months \\
\hline Public discussion and addressing objections & $6-12$ months \\
\hline Agreements with property owners & 6 months \\
\hline Construction Implementation Project & 6 months \\
\hline Designing and construction procedures & $12-18$ months \\
\hline Purchase of properties & $3-6$ months \\
\hline $\begin{array}{l}\text { Call for tenders, selection of a contractor, including the resolution of other applicants' } \\
\text { objections }\end{array}$ & $6-12$ months \\
\hline The construction itself & $12-24$ months \\
\hline Total duration & $81-126$ months \\
& (approximately $7-10.5$ years) \\
\hline Source: Vnouček, 2010, p. 33. & \\
\hline
\end{tabular}


The entire process is, in terms of time, enormously demanding, turning into a pretty great problem especially with respect to reaction to renewables' development. The National Renewable Energy Action Plan of the Czech Republic has sets the goal that the Czech Republic will in 2020 have a power system with $743 \mathrm{MWe}$ of installed capacity in public power plants and 1,695 MWe of installed capacity in photovoltaic power plants (see MPO, 2010e, p. 69). Already by January 1, 2011, there has been, however, 217.8 MWe installed in wind power plants and 1,959.1 MWe in photovoltaic ones. The regulation of the unstable and hard to predict capacity of these power plants will cost the Czech Republic almost 50 billion CZK delivered to CEPS for its ancillary services.

The technical limit of electricity regulation in the Czech Republic is identified, after a total of positive and negative regulation, as amounting to 1,585 MWe during daily regulation and 1,395 MWe during night regulation. According to a study by EGU Brno, a. s., the technical limit will in 2013-2015 reach 2,000 MWe, while the distribution companies show evidence that the sum of potential capacity (based on the issued connection approvals) was by January 31, 2010, 8,063 MWe from renewables $(5,277 \mathrm{MWe}$ from photovoltaic plants and 2,786 MWe from wind plants) (see Jabůrková, 2010, p. 320-321).

The Czech Republic has peak and semi-peak electricity regulation plants. Peak power plants are the Orlik wind power plant, Dlouhe strane pumped-storage hydroelectricity, hydropower plants with more than 1 MWe and the Vresova combined cycle power plant. Semi-peak power plants are the Melnik, Prunerov I, Tisova, Chvaletice, Detmarovice and Hodonin power plants (see Růžička, 2009). These sorts of power plants are selected for their capability of a quick change of capacity and quick connection to the grid, as previously described (see comparison in table No. 8.11).

\begin{tabular}{|c|c|c|c|c|c|}
\hline \multicolumn{6}{|c|}{ Tab. 8.11: Comparison of Different Types of Power Plant } \\
\hline $\begin{array}{l}\text { Type of Power } \\
\text { Plant }\end{array}$ & $\begin{array}{l}\text { Price of Elec- } \\
\text { tricity }\end{array}$ & Capacity & $\begin{array}{l}\text { Speed of Connec- } \\
\text { tion to the Net- } \\
\text { work }\end{array}$ & $\begin{array}{l}\text { Share of Fuel } \\
\text { Costs }\end{array}$ & $\begin{array}{l}\text { Provision of Raw } \\
\text { Material Supplies }\end{array}$ \\
\hline Nuclear & Very low & $\begin{array}{l}\text { Constant, a low degree } \\
\text { of regulation capacity }\end{array}$ & Hours up to days & $\begin{array}{l}20-25 \% \text { of total } \\
\text { costs }\end{array}$ & $\begin{array}{l}20 \text { tonnes of fuel } \\
\text { per year for } 1,000 \\
\text { MW of capacity }\end{array}$ \\
\hline $\begin{array}{l}\text { Hydroelectricity } \\
\text { (pumped-storage } \\
\text { hydroelectricity, } \\
\text { hydropower plants) }\end{array}$ & Low & $\begin{array}{l}\text { Constant capacity, de- } \\
\text { pendent on the flow, can } \\
\text { be well regulated }\end{array}$ & Tens of seconds & $0 \%$ & Without problems \\
\hline $\begin{array}{l}\text { Brown coal, Bitu- } \\
\text { minous coal }\end{array}$ & $\begin{array}{l}\text { Similar to nucle- } \\
\text { ar power plants }\end{array}$ & $\begin{array}{l}\text { Constant capacity, a me- } \\
\text { dium degree of regula- } \\
\text { tion capacity }\end{array}$ & Tens of minutes & $50-66 \%$ & $\begin{array}{l}\text { Storage problems, } \\
\text { it requires its } \\
\text { own source in the } \\
\text { vicinity, consump- } \\
\text { tion ranges around } \\
\text { a train of coal per } \\
\text { day }\end{array}$ \\
\hline $\begin{array}{l}\text { Gas (combined } \\
\text { cycle, gas and fuel } \\
\text { power plant) }\end{array}$ & High & $\begin{array}{l}\text { Constant capacity, can } \\
\text { be well regulated }\end{array}$ & $\begin{array}{l}\text { A matter of min- } \\
\text { utes }\end{array}$ & $66-75 \%$ & $\begin{array}{l}\text { It demands its own } \\
\text { source or a pipeline }\end{array}$ \\
\hline Wind & Potentially low & $\begin{array}{l}\text { Varying capacity, cannot } \\
\text { be regulated, completely } \\
\text { dependent on regulation } \\
\text { capacity }\end{array}$ & $\begin{array}{l}\text { Unstable, unreli- } \\
\text { able and hard to } \\
\text { anticipate, under } \\
\text { windy conditions, } \\
\text { tens of seconds. }\end{array}$ & $0 \%$ & Without problems \\
\hline
\end{tabular}




\begin{tabular}{|l|l|l|l|l|l|}
\hline $\begin{array}{l}\text { Photovoltaic (Solar } \\
\text { power plant) }\end{array}$ & Potentially low & $\begin{array}{l}\text { Varying capacity, cannot } \\
\text { be regulated, completely } \\
\text { dependent on accumula- } \\
\text { tion capacity }\end{array}$ & $\begin{array}{l}\text { Unstable, unreli- } \\
\text { able and hard to } \\
\text { anticipate. Should } \\
\text { the sun shine } \\
\text { (therefore, during } \\
\text { daytime) in tens of } \\
\text { seconds. }\end{array}$ & $0 \%$ & Without problems \\
\hline
\end{tabular}

Source: Škoda, 2010; For capacity figures, see Štěrba, 2006. Modified by T. Vlček, reprinted with the approval of R. Škoda.

With regard to the planned increase in photovoltaic and wind power plants, we can, therefore, assume that the coming years will see greater production of electricity from wind and photovoltaic facilities than enabled by the current technical regulation limit, without jeopardizing the stability of the power system. There is generally, for example, a need to increase ancillary services by around $20 \%$ of total capacity installed in wind power plants (see Belyuš, 2009, p. 582).

The whole regulation issue is, moreover, marked by sudden, hardly regulated cross-border flows of electricity from Germany, which enters the Czech Republic via the V445 and V446 lines from Röhrsdorf. The Czech Republic is connected with ten $110 \mathrm{kV}$, six $220 \mathrm{kV}$ and eleven $440 \mathrm{kV}$ cross-border lines, while in the case of Germany it is four $440 \mathrm{kV}$ lines, two at the north-western and two at the south-western border.

The installed capacity of German wind power plants located in the north in 2009 amounted to approximately 23,000 MWe, while it should by 2030 increase by another 30,000 MWe (see Belyuš, 2009, p. 582), which truly means a massive capacity of up to 53 thousand MWe (for comparison, the total installed capacity of the Czech Republic was as of December 31, 2012, 20,520 MWe).

"This problem is far from being the Czech Republic's concern only, but the production of the wind power plants in northern Germany overloads the lines of system operators in Poland, Slovakia, the Czech Republic, the Netherlands, Belgium, Switzerland, making up in the Czech Republic's case 1,500 to 1,700 MWe of unexpected flows. The main reason is the problem of transmission of produced electricity from northern Germany to users in central and southern parts of Germany" (see Cieslar, 2010c). Germany in this relation lacks 3,600 km of electricity lines (see Neuerer, 2011). A surplus of German electricity from wind, which for technical reasons cannot be supplied to German users, is usually purchased by Russian and Swiss pumped-storage hydropower plants, which in that manner obtain less expensive electricity for pumping water also during the day. In addition to significant expenses associated with power system regulation in the event of a flow of wind electricity from Germany, CEPS in the long term (approximately after 2015) plans to modernize and increase the capacity of $400 \mathrm{kV}$ lines, which are the most loaded routes during the transfers from Germany to Austria, while these investments would require more than 3.8 billion CZK. The present model of financial regulation of transmission system operators in the EU is solved separately, i.e. "there is no possibility of financial compensation for investment stimulated by external conditions and any compensation of flows from Germany is, therefore, paid for by the Czech user" (see Belyuš, 2009, p. 582).

Germany is, of course, aware of its problem and it is searching for the means to solve it. Besides the long-term cooperation of transmission system operators, for example, Minister of Industry and Trade, Martin Kocourek, in April 2011 met with his German counterpart, Rainer Bruderle, to set up a working group for coordination of transmission networks development, which will with the greatest likelihood include Poland as well. Aside from this, there is the new Mittelsbüren gas power plant emerging in Germany, which should start running in 2013 with $440 \mathrm{MWe}$ of installed capacity. The security aspect of this power plant is significant mainly for the German company Gemeinschaftskraftwerk Bremen, which intends with this plant to cover fluctuations of electricity production in local wind power plants (see "Stabilizace dodávek," 2011, p. 6). 
The Czech Republic is currently building a new regulation plant, specifically the Pocerady combined cycle power plant with 838 MWe of capacity (it should undergo a test operation at the end of June 2013). This power plant will, however, like other new combined cycle plants (Melnik, Mochov, etc., see above) function also as a base load and not only as a regulation reserve. Only one can hardly find an investor to lend money for a new power plant which would be aimed at regulation purposes only. The ratio between invested finances and stable income is significantly against the success of such a project.

\subsection{Crisis or a Revolutionary Change in the Electric Power Industry}

In 2006, the Expert Energy Security Working Group under the Committee for Foreign Security Policy Coordination prepared a report for the National Security Committee in which it, among other things, noted that "despite the liberalization of the electricity market, the latter is dominated by a very dominant company, which causes a low level of competition" (see Odborná pracovní skupina pro energetickou bezpečnost Výboru pro koordinaci zahraniční bezpečnostní politiky, 2006, p. 8-9). The working group was, therefore, right in both cases, but these claims can be assessed anew with respect to the events of the last five years.

It proves that, even though the dominant position of CEZ remains undisputable, this position is increasingly disrupted as the result of non-state market regulation. The character of the Czech electric power sector is very strongly affected by the sector's historical development, when it was originally built for purposes of centralized production and transmission. The requirements which the current sector development imposes on the electricity industry are, therefore, limited predominantly in technical terms (in addition to the evident rigid attitude of the national electricity elite, especially in relation to renewables and decentralization). It is entirely evident that CEZ has no intention of losing its dominant position, responding to the developing situation in its own manner, such as, for example, by initiating the project of electricity production from renewables or by fighting trading newcomers in the market.

The present (European and thus Czech as well) trend is rather clear. It takes the direction of the development of renewable energy sources, efforts to accomplish greater energy efficiency and energy savings, while there are also the signs of initial steps on a way of shifting to a decentralized energy sector. There is no such investor which would be interested in building new large classic sources (with the exception of Ledvice), because the return on investments is far from certain. With respect to where the development is directed and to gradual termination of the existing large coal blocks, the Czech electric power industry is in the forthcoming years to expect either quite likely a state of crisis associated with a drop in electricity production from coal and with electricity regulation (from renewables, from the development of electric vehicles and necessary infrastructure, etc.) in the grid, or a revolutionary change. The latter would rest on the ability to manage the increasing electricity consumption in the Czech Republic (see table No. 8.12) when turning to a new arrangement of the electric power industry. 


\begin{tabular}{|l|c|c|c|c|c|c|c|c|c|}
\hline \multicolumn{7}{|l|}{ Tab. 8.12: Forecast of the Future Course of Electricity Consumption in the Czech Republic (GWh) } \\
\hline & $\mathbf{2 0 1 0}$ & $\mathbf{2 0 1 1}$ & $\mathbf{2 0 1 2}$ & $\mathbf{2 0 1 3}$ & $\mathbf{2 0 1 4}$ & $\mathbf{2 0 1 5}$ & $\mathbf{2 0 2 0}$ & $\mathbf{2 0 3 0}$ & $\mathbf{2 0 4 0}$ \\
\hline $\begin{array}{l}\text { High Energy } \\
\text { Users }\end{array}$ & 35,547 & 36,059 & 36,566 & 37,177 & 37,963 & 38,788 & 42,461 & 45,752 & 47,249 \\
\hline $\begin{array}{l}\text { Low Energy } \\
\text { Users }\end{array}$ & 23,319 & 23,649 & 24,144 & 24,636 & 25,018 & 25,393 & 27,131 & 29,245 & 30,593 \\
\hline $\begin{array}{l}\text { Household Low } \\
\text { Energy Users }\end{array}$ & 8,375 & 8,525 & 8,840 & 9,165 & 9,377 & 9,597 & 10,571 & 11,543 & 12,027 \\
\hline $\begin{array}{l}\text { Business Low } \\
\text { Energy Users }\end{array}$ & 14,944 & 15,124 & 15,304 & 15,472 & 15,640 & 15,796 & 16,560 & 17,702 & 18,566 \\
\hline Net & $\mathbf{5 8 , 8 6 6}$ & $\mathbf{5 9 , 7 0 8}$ & $\mathbf{6 0 , 7 1 0}$ & $\mathbf{6 1 , 8 1 3}$ & $\mathbf{6 2 , 9 8 1}$ & $\mathbf{6 4 , 1 8 2}$ & $\mathbf{6 9 , 5 9 2}$ & $\mathbf{7 4 , 9 9 7}$ & $\mathbf{7 7 , 8 4 2}$ \\
\hline Loses & 4,666 & 4,729 & 4,806 & 4,890 & 4,979 & 5,070 & 5,477 & 5,854 & 6,028 \\
\hline $\begin{array}{l}\text { - in the transmis- } \\
\text { sion system }\end{array}$ & 747 & 758 & 770 & 783 & 796 & 810 & 872 & 927 & 949 \\
\hline $\begin{array}{l}\text { - in the distribu- } \\
\text { tion system }\end{array}$ & 3,919 & 3,972 & 4,035 & 4,107 & 4,182 & 4,260 & 4,605 & 4,928 & 5,079 \\
\hline Net incl. loses & $\mathbf{6 3 , 5 3 1}$ & $\mathbf{6 4} \mathbf{4 3 7}$ & $\mathbf{6 5 , 5 1 6}$ & $\mathbf{6 6 , 7 0 3}$ & $\mathbf{6 7 , 9 6 0}$ & $\mathbf{6 9 , 2 5 2}$ & $\mathbf{7 5 , 0 6 9}$ & $\mathbf{8 0 , 8 5 1}$ & $\mathbf{8 3 , 8 7 0}$ \\
\hline Source: OTE, a. s., $2011, \mathrm{p} .10$. & & & & & & & \\
\hline
\end{tabular}

This new character will find its expression in constantly increasing interest in electricity, as its use would be clean and without losses (which is not the case with production). It will involve the constantly increasing implementation of renewables into production, and not only of existing photovoltaic and wind plants, but of geothermal sources, biomass, biogas stations and waste combustion. Large classic condensation sources of electricity with enormous capacity will over time be replaced by smaller co-generation units, which will better correspond to the decentralized system of demand, use and production.

The electricity grid will be under the enormous pressure. CEPS, in 10 to 15 years expects the emergence of a qualitatively new energy sector, which will, among other things, include "a change of primary sources' capacity structure and a partial shift of producing capacities onto the level of distribution networks, developed mechanisms of use control through smart systems and their interconnection with the market setting, integration of the national network control into supranational aggregates and interconnection of the market with electricity, services and regulation energy" (see Kovačovská, 2011, p. 26-27). The Czech electricity grid was not built for such major and unanticipated electricity transmission changes, where users are accordingly electricity suppliers, while their modernization in terms of modern smart grids will require sky-high investment.

The Czech Republic is the second largest electricity exporter in Europe, behind France. If it wishes to keep this position, the completion of Temelin nuclear power plant is basically a must. This requires even higher investment, but so will safety of electricity supplies increase in a similarly steep manner. This situation in the nuclear power industry is very aptly summarised by Petr Otcenasek, saying: "The expected nuclear renaissance stopped at the instant the combustion of oil, natural gas and coal faced problems related to their exhaustion already in the $21^{\text {st }}$ century and with possible negative biosphere impacts" (see Otčenášek, 2011, p. 271). 
Table No. 8.13 displays the problems, risks and advantages of potential construction of a new large power plant. Although decentralization and renewables are part of a modern trend, moreover, receiving strong support from the EU, the Czech Republic is not at this point prepared to undergo a massive shift to this sort of electricity production.

\begin{tabular}{|l|l|}
\hline Tab. 8.13: The Potential Construction of New Electricity Sources \\
\hline Source & Effect \\
\hline Brown coal & $\begin{array}{l}\text { Increasing pressure to breach the environmental territorial limits of mining; absolute surrender on reduc- } \\
\text { tion of greenhouse gas emissions. }\end{array}$ \\
\hline Bituminous coal & $\begin{array}{l}\text { Uncertain supply (in comparison to brown coal, reserves of Czech bituminous coal have an even lower } \\
\text { lifespan), should imports of coal prove necessary (Poland, Ukraine), there is an absolute resignation from } \\
\text { an environmental dimension to the project (overwhelming environmental effects of transportation of an } \\
\text { enormous amount of materials) and an absolute resignation from reducing greenhouse gas emissions. }\end{array}$ \\
\hline Gas & $\begin{array}{l}\text { Given that the Czech Republic does not have any relevant sources of natural gas at its disposal and given } \\
\text { that the only true supplier, Russia, employs a policy of using dependence on raw materials' imports in } \\
\text { order to pave the way for its political interests, such a decision would signify giving up on the energy } \\
\text { security of the Czech Republic. }\end{array}$ \\
\hline Nuclear & $\begin{array}{l}\text { Although demanding technically and time-wise, this is the solution which would enhance Czech energy } \\
\text { security. }\end{array}$ \\
\hline Source: Kavina, 2009, p. 326.
\end{tabular}

The investment necessary for modernizing and keeping the transmission system stable would be astronomic. A more realistic development would be where electricity (and heat) is produced from renewables within households (photovoltaic power plants, solar thermal exchangers, biomass boilers, biogas stations, waste-to-energy processing, hydropower plants, etc.) in order to reduce consumption from the centralized power system. This direction is already set and, despite significant problems (see the chapter about renewables), it is likely that the energy sector will continue on that course. However, even in the distant future, it will be impossible to entirely resign from having a centralized network, as renewables and smaller co-generation units will never be able to provide the massive amounts of electricity required by blast furnaces, ironworks and other large undertakings that are demanding electricity consumers.

If we do not set the clear and long-term direction of the Czech power industry (within a State Concept) soon, the country will in the coming years experience either a great electric power industry crisis resulting from hesitancy and inconsistency, or a major, financially enormously demanding, change in the electric power industry, should renewables remain supported as much as they are today. 


\section{Acknowledgements}

The previous pages presented the basic characteristics of the Czech energy sector, including selected weak and strong points, challenges and opportunities. In addition to the benefits of such an undertaking, the effort to deliver a complex picture, naturally, also brings some difficulties, often excessive generalization, understatement of some interesting or important questions or the possibility of inaccurate use of particular information in the whole context. Potential mistakes of that sort as well as any other errors in the book are the exclusive responsibility of the authors of the text.

The authors would like to thank the Department of International Relations and European Studies at the Faculty of Social Sciences, Masaryk University, on whose soil the text emerged in an atmosphere of a maximum goodwill and support. A long list of energy experts deserve a word of gratitude of their own, who in vast numbers visited the Department and provided our students with a number of lectures, information from which helped to improve the quality of the text. Even though the burden of the publication's writing was carried only by the authors, the rest of the team engaged in the energy issues at the Department of International Relations and European Studies at the Faculty of Social Sciences, Masaryk University (KMVES FSS MU) made contributions in terms of consultancy and consultations.

Special thanks then go predominantly to Olivera Radovanović for her great work in translating the book, and then to Veronika Zapletalová and Petra Bendlová for preparing smaller parts of the text as well as for helpful remarks on the entire book.

The translations of Czech sources are carried out by our own translator, if the reader wishes to use translated text for legal or official purposes he or she should check to see what the official cersion is.

The book would not have emerged without the financial support of the European Social Fund within the project of The Education for Competitiveness Operational Programme (ECOP) under the jurisdiction of the Ministry of Education, Youth and Sports of the CR (MEYS) "Innovation of lecturing at FSS - the Department of International Relations and European Studies" (CZ 1.07/2.2.00/15.0221); and the specific research project of the Department of International Relations and European Studies "Current Issues of European and International Politics" (MUNI/A/0754/2012). 


\section{About the Authors}

PhDr. Tomáš Vlček completed an advanced post-Master's State Examination and Master's studies at the Department of International Relations and bachelor's studies at the Department of Security and Strategic Studies at the Faculty of Social Studies, Masaryk University. He is currently engaged in the study program International Relations and Energy Security at the Department of International Relations and European Studies at the same faculty and at the International Institute for Political Science of Masaryk University. The mentioned program responds to requirements both from the business and public spheres in their search for experts combining expertise in the field of international relations with acquaintance with the energy sector. Tomáš Vlček participates as a lecturer in courses on the energy security of the Czech Republic, the nuclear energy sector and environmental aspects of the energy sector. He is professionally devoted to issues of Czech energy security, with special reference to the nuclear and electric power sectors.

Mgr. Filip Černoch, Ph.D. completed his doctorate at the Department of European Studies at the Faculty of Social Studies, Masaryk University, where he is also currently engaged as an expert researcher and lecturer at the Department of International Relations and Energy Security. He is professionally devoted to energy security of the Czech Republic and the EU, the legislative dimension of the energy sector at the EU level and to the EU's influence on Czech energy security. Among other duties he lectures on the courses Energy Security of the EU, Energy Policy of the EU, Energy Security of the Visegrad Countries, Energy Security of the EU and of the Selected European Countries and Transatlantic Relations and Energy Security. 


\section{Bibliography}

\section{Printed Sources}

10 let elektrárenské společnosti ČEZ, a. s. (2002). Česká energetika, 2002(6), pp. 3-7.

Americká skupina Appian koupí státní podíl v Mostecké uhelné. (1999, May 14). Mladá fronta DNES, p. 14. Adámková, A. (2010a). Boj o energetické uhlí zatím nekončí. Pro-Energy magazín, 2010(1), pp. 68-69.

Bačík, O. (2008). Bioplynové stanice: technologie pro 21. století. Energie 21, 2008 (2), pp. 27-29.

Baldia, P., \& Papp, E. J. (2007). Erdgasdrehscheibe Österreich. FORUM Gas Wasser Wärme, 2007(3), p. 6-10.

Baran, V. (2002). Jaderná energetika a dalši problémy moderní civilizace. Praha: Academia.

Bártek, D. (2003a, August 4). Uhlobaronům zhořkl koláček, Respekt, 2003, p. 8.

Bártek, D. (2003b, December 8). Uhlobaronům skončila dolce vita, Respekt, 2003, p. 8.

Bártek, D. (2003c, March 24). Od incestu k miliardám. Respekt, 2003c, p. 8.

Bártík, F. (2009). Tábory nucené práce se zaměřením na tábory zř́zené při uranových dolech v letech 1949-1951. Sešity Úřadu dokumentace a vyšetřování zločinů komunismu, (17). Praha: Úřad dokumentace a vyšetřování zločinů komunismu PČR.

Bautzová, L. (2001, December 6). Kdo a s kým do českého plynu. Ekonom, 2001, p. 14.

Belyuš, M. (2009). Rozvoj obnovitelných zdrojů by měl odpovídat rozvoji sítí. Vesmír, 88(9), pp. 582-583.

Beranovský, J. a kol. (2007). Energie slunce - výroba elektřiny. Informační publikace, Praha/České Budějovice: EkoWATT, Centrum pro obnovitelné zdroje a úspory energie.

Bílý, T. (2011). Reaktory pro dostavbu Temelína. Energetika, 61(5), p. 268-270.

Blažek, L. (2009). Ohřejeme se v 21. století? O výstavbě a rozvoji palivo-energetické základny. Praha: FUTURA.

Blažek, J. \& Rábl, V. (2006). Základy zpracování a využití ropy. Praha: Vysoká škola chemicko-technologická v Praze.

Boháček, I. (2007). Elektrizační sít’. Vesmír, 86(1), pp. 32-33.

Buchan, D. (2009). Energy and Climate Change: Europe at the Crossroads. New York: Oxford University Press Buryan, P. (2007). Bioplyn jako perspektivní plynné palivo. Plyn, LXXXVII(10), pp. 221-226.

Business Monitor International. (2010). Oil \& Gas Hungary Q1 2010. London: Business Monitor International.

Cieslar, S. (2010a). „V př́padě realizace bloků s výkonem 2 x 1700 MW bude navíc nutné navýšit přenosovou kapacitu na profilech Kočín-Přeštice a Mírovka-Čebín,“ uvedl v rozhovoru pro časopis All for Power Ing. Andrew Gayo Kasembe, vedoucí odboru rozvoj společnosti ČEPS, a. s. All for Power, 4(3), pp. 58-60.

Cílek, V. (2008). Energetická bezpečnost České republiky - Rizika a výhledy. Vesmír, 87(9), pp. 582-588.

Černoch, F. (2008). Energetická politika EU: pozice na půli cesty. In Waisová, Š. (Ed.), Evropská energetická bezpečnost (pp. 65-84). Plzeň: Aleš Čeněk, s. r. o. 
Černoch, F. (2010). Energetická politika. In Balík, S., \& Císař, O., \& Fiala, P., \& kol. (Eds.), Veřejné politiky v České republice v letech 1989-2009 (pp. 141-167). Brno: Centrum pro studium demokracie a kultury.

Černoch, F. (2011). Energetická politika ČR a Energetické zájmy EU (Dizertační práce, nepublikováno). Masarykova univerzita, Brno.

Černoch, F. \& Dančák, B. \& Kod’ousková, H. \& Leshchenko, A. \& Ocelík, P. \& Osička, J. \& Šebek, V. \& Vlček, T. \& Zapletalová, V. (2012). The Future of the Druzhba Pipeline as a Strategic Challenge for the Czech Republic and Poland. Brno: Mezinárodní politologický ústav.

Černoch, F. \& Dančák, B. \& Kovačovská, J. \& Ocelík, P. \& Osička, J. \& Vlček, T. \& Zapletalová, V. (2011). The Future of Natural Gas Security in the V4 Countries: A Scenario Analysis and the EU Dimension. Brno: Mezinárodní politologický ústav.

Česká energetika na začátku roku 1995. (1995). Energetika, 1995(1), pp. 1-2.

ČEZ, a. s. (2003). Encyklopedie energetiky. Praha: С̆EZ, a. s.

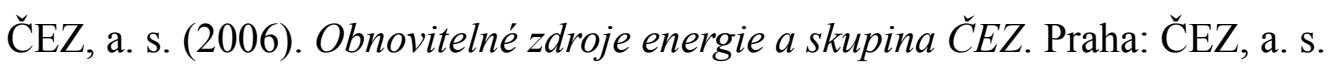

ČEZ, a. s. (2010b). Jaderné elektrárny v roce 2009. Praha: ČEZ, a. s.

ČEZ popírá, že Temelín bude dvakrát dražší. (1994, February 16). Rudé právo, 1994, p. 2.

Doubek, J. (2006). Nové a ještě novější. Třetí pól, 2006(4), pp. 6-7.

Druzhba Pipeline. (2009). Pipelines International 1(1), pp. 56-57.

Duda, V. (2002). Ekonomické aspekty koncepce nakládání s RAO a VJP. Česká energetika, 2002(1), pp. 46-47.

Dufková, M. (2005). Z čeho se skládá cena elektřiny? Třetí pól, 2005(12), p. 2.

Dvoř́čck, J. (2001). Present State of Hard Coal Underground Mining in the Czech Republic. In IMCET, Proceedings of the Seventeenth International Mining Congress and Exhibition of Turkey. Ankara: The Chamber of Mining Engineers of Turkey.

Eckertová, L. (1996). Získávání sluneční energie. Doprovodný metodický text k videokazetě v rámci vzdělávacího programu Energie pro každého. Praha: ČEZ, a. s.

Elektřina a pára - trvalé spojenectví. (2006). Třetí pól, 2006(2), pp. 14-15.

Energetické hospodářství České republiky. (1999). Energetika, 1999(11).

Energetické hospodářství ČR v analýze MPO. (2003). Energetika, 2003(5).

Energetický regulační úřad. (2011d). Výsledky provozu ES ČR za prosinec 2011. Energetika, 61(3), p. 152.

Erban, P. (1999). Jednotky používané v energetice. Energetika, 1999 (10), pp. 326-327.

Ethik $\square$ Kommission Sichere Energieversorgung. (2011). Deutschlands Energiewende - Ein Gemeinschaftswerk für die Zukunft. Berlin.

Farský, M., \& Neruda, M. (2004). Konec těžby uranu v horním povodí Ploučnice - O jednom „ekologickém dědictví". Vesmír, 83(6), pp. 326-329, 332-333.

Ferguson, E. S. (1988). Review: Edison's Electric Light: Biography of an Invention by Robert Friedel; Paul Israel; Bernard S. Finn. Technology and Culture, 29 (1), pp. 153-155. 
FNM bojuje s důlními giganty a ČSSD. (1998, March 9). Lidové noviny, 1998, p. 15.

Fousek, Z. (1998, October 29). Česká energetika před vstupem do EU. Ekonom, 1998, p. 4.

Gavor, J. (2010). Jak přežít s limity - Bolavé místo české energetiky čas nezhojí. Přežijí ti lépe připravení. Pro-Energy magazín, 2010(3), pp. 14-17.

General Secretariat of the Council of the European Union. (2010, January 14). Proposal for a Regulation of the European Parliament and of the Council concerning measures to safeguard security of gas supply and repealing Directive 2004/67/EC. Brussels: Council of the European Union.

Geussová, F. (2001, December 6). Privatizační horečka stoupá. Ekonom, 2001, p. 17.

Geussová, M. (2000a, July 20). Temelínská mela. Ekonom, 2000, p. 10.

Geussová, M. (2000b, May 11). Nedovařená lahůdka. Ekonom, XLIV(19), pp. 28-29.

Geussová, M. (2002, January 10). Elektrické napětí. Ekonom, 2002, p. 18.

Geussová, M. (2010). Zavřít, nebo nechat předělat? Pro-Energy magazín, 2010(1), pp. 26-28.

Gruner, M. (1992, June 29). Bitva u Temelína. Respekt, 1992, p. 5.

Hermann, P., Noskievič, P. \& Kolat, P.(1998). Palivové články v uhelné energetice. Acta Montanistica Slovaca, 3, pp. 301-306.

Hladíková, S. (2009). Společnost RWE Energie zahájila. Plyn, LXXXIX(9), pp. 202-203.

Hlubinný důl Centrum prodloužil činnost do roku 2012. (2009). Vesmír, 6, p. 412.

Hnilica, F. (1946). Vývoj elektrisace východní a severní Moravy. Olomouc: Obchodní a živnostenská komora v Olomouci.

Holec, P. (2010). Černá díra Jiřetín - Jaké jsou skutečné názory Jiřího Paroubka na těžební limity? Reflex, 7, p. 16.

Holub, L., Švaigl, O., Nevosad, M., Soukup, A., \& Kopal, R. (2005). Století benzínu - Historie rafinérského průmyslu v českých zemích. Praha: Asco - vydavatelství spol. s r. o. pro Českou rafinérskou, a. s.

Honěk, J. (2005). Hodnocení uhlí a uhelných zásob v České republice podle mezinárodních klasifikací. In Sbornik věd. prací VŠB-TU Ostrava, řada hornicko-geologická (pp. 373 - 380).

Honěk, J., Staněk, F., Hoňková, K., \& Jelínek, J. (2009). Uhelné sloje v jihomoravském lignitovém revíru. Acta Montanistica Slovaca, 1, pp. 43-54.

Horáček, P. (1993). Vztahy energetické a ekologické politiky. Energetika, 1989(12), pp. 395-397.

Horáček, P. (1999). Čistší ovzduší i doma. Vesmír, 78(5), pp. 272-273.

Horák, K. (1975). Československá energetika 1945-1975. Historická geografie, 1975(13), pp. 35-43.

Horová, J. (2009, listopad). Elektrická energie - obchodování na burze. Prezentace PXE, a. s., Burza cenných papírů Praha, a. s., Praha.

Horská, \& Vrbová, P. (1961). Počátky elektrisace v českých zemích. Rozpravy Československé akademie věd, Řada společenských věd, 71(sešit 13). Praha: Nakladatelství Československé akademie věd.

Hudema, M. (2005, February 28). Koláček na mostě. Respekt, 2005, p. 3. 
Hutnictví železa, a. s. (2007, December). SITUAČNÍ ZPRÁVA: Úvaha dalšího vývoje ocelářského průmyslu České republiky. Určeno pro Konzultativní tým MPO a OS KOVO.

Chemišinec, I., Marvan, M., Nečesaný, J., Sýkora, T., \& Tůma, J. (2010). Obchod s elektřinou. Praha: CONTE spol. s r.o.

Invicta Bohemica. (1999). Analýzy energetického komplexu $\check{C} R$. Praha: Invicta Bohemica.

International Energy Agency. (2005). Energy Policies of IEA Countries - The Czech Republic 2005 Review. Paris: IEA Publications.

International Energy Agency (2009a). CO2 Emissions from Fuel Combustion 2009. Paris: IEA Publications. International Energy Agency. (2009b). Coal Information 2009. Paris: IEA Publications.

International Energy Agency. (2009c). Energy balances of OECD countries. Paris: IEA Publications.

International Energy Agency. (2009d). Energy Statistics of OECD Countries 2009. Paris: IEA Publications. International Energy Agency. (2009e). Electricity Information 2009. Paris: IEA Publications.

International Energy Agency. (2009f). Natural Gas Information 2009. Paris: IEA Publications.

International Energy Agency. (2009g). Oil Information 2009. Paris: IEA Publications 2009.

International Energy Agency. (2009h). Renewables Information 2009. Paris: IEA Publications.

International Energy Agency. (2009i). World Energy Outlook. Paris: IEA Publications.

Jabůrková, J. (2010). Jak se neocitnout ve tmě. Pro-Energy magazín, 2010(1), pp. 36-39.

Jabůrková, J. (2010). Obnovitelná elektřina není černý pasažér. Vesmír, 89(5), pp. 320-321.

Jevič, P. (2010). Motorová biopaliva - otázky a odpovědi. Energie 21, 2010(3), pp. 22-25.

K aktualizaci státní energetické koncepce. (2003a). Energetika, 2003(2), p. 39.

Kafka, J. a kol. (2003). Rudné a uranové hornictvi České republiky. Ostrava: Anagram ve spolupráci s Diamo s.p.

Kaniok, P. (2010). České předsednictví Rady EU - most přes minulost. Munipress: Brno.

Kavina, P. (2009). Surovinové zdroje. In Potůček, M., \& Mašková, M. (2009, Eds.), Česká republika trendy, ohrožení, př́ležitosti (pp. 307-330). Praha: Karolinum.

Kindl, V., \& Spilková, T., \& Vaňousek, I., \& Stehlík, J. (1996). Ekologizace uhelných elektráren ČEZ, a. s., na postupu. Energetika, 1996(9), pp. 284-286.

Kocourek, M. (2011). Potřebujeme vyvážený mix energetických zdrojů. Hospodářské noviny, Energetika - Průvodce světem energii a jejich úspor, pp. 10-12.

Kolat, P. \& Roubíček, V., \& Kozaczka, J. (2008). Pokročilé energetické technologie. Skripta pro Katedru energetiky Fakulty strojní, Vysoká škola báňská - Technická univerzita Ostrava.

Kolektiv autorů. (1985). Uhelné hornictví v ČSSR. Ostrava: Profil.

Kopačka, L. (1980). Energetická základna v hospodářském vývoji ČSSR po roce 1945. Hospodářské dějiny, 1980 (6), pp. 147-226. 
Kopačka, L. (1982). Elektroenergetika ve vývoji československého hospodářství po roce 1945. Historická geografie, 1982(20), pp. 203-247.

Korbel, P., \& Kostka, V. (2011, May 5-11). Nová práce pro Řež. Ekonom, roč. LV(18), p. 30.

Koutský, B., Malecha, J., Buryan, P., \& Najsr, J. (2000). Využití zplyňování dřevin a odpadů pro výrobu energie. In Kolektiv autorů. (Eds.), Energetika a životní prostředí IX. - Paliva pro 21. století a 3. Tisíciletí (pp. 61-67). Ústí nad Labem: Dům techniky Ústí, s. r. o.

Kovačovská, L. (2011). Dlouhodobá strategie přenosové soustavy. Energetika - Prưvodce světem energií a jejich úspor, 2011(5), pp. 26-27.

Kratochvíl, P. (2010). Národní zájem a jeho legitimita. In Drulák, P. \& Střítecký V. (eds.): Hledání českých zájmů. Mezinárodní bezpečnost. (pp. 17 - 30). Praha: Ústav mezinárodních vztahů.

Křepel, J. (2001a). Proč je radioaktivní? Třetí pól, 2001(12), pp. 8-9.

Křepel, J. (2001b). Vyhořelé jaderné palivo - surovina nebo odpad? Třetí pól, roč. 2001(11), pp. 4-5.

Kubín, M. (1989). 100 let veřejné energetiky v ČSSR. Energetika, 1989(10), pp. 362-367.

Kubín, M. (2003). Energetika: Perspektiva - Strategie - Inovace v kontextu evropského vývoje. Brno: Jihomoravská energetika, a. s.

Kubín, M. (2009). Proměny české energetiky. Praha: Český svaz zaměstnavatelů v energetice.

Kubín, M. a kol. (1993). Rozvoj energetiky jižní Moravy. Brno: JMEP s.p.

Kubizňák, J. (2011). Komunikace s Jiřím Kubizňákem, Manažerem vyhodnocení a vypořádání odchylek elektřiny, OTE, a. s.

Kučera, D. (2009). Pád společnosti Moravia Energo - aneb jaká rizika jsou spjata s obchodováním s elektrickou energií. Pro-Energy magazín, 2009(3), pp. 20-22.

Kučera, D.(2010). Sázka na budoucnost. Pro-Energy magazín, 2010 (1), pp. 24-25.

Kučera, J. (1999, February 18). Svobodné elektrony. Ekonom, 1999, p. 38.

Kundra, O. (2010). Nejsem politik S ministrem Janem Dusíkem o důvodech jeho nečekané rezignace. Respekt, XXI(12), p. 15.

Kundra, O. (2010). Překvapení v kauze Bursík. Respekt, XXI(6), pp. 22-23.

Kvaček, R. a kol. (1990). Dějiny Československa II - 1648-1918. Praha: SPN.

Kysilka, H. (2009). Jak posílit bezpečnost dodávek plynu. Vesmír, 88(3), pp. 176-177.

Laciok, A., Marková, L., \& Vokál, A. (2000). Co s vyhořelým palivem? Bez hlubinného úložiště se neobejdeme. Vesmír 79(4), pp. 190-195.

Lázňovský, M. (2010). Krátký uhelný oddych. Ekonom, LIV(24), pp. 46-49.

Loucká, P. (2004). Počátky těžby uranu v českých zemích. Vesmír, 83(6), pp. 330-331.

Majer, J. (2004). Rudné hornictví v Čechách, na Moravě a ve Slezsku: Obrazy z dějin těžby a zpracování. Praha: Libri.

Marek, J. (2007). Radioaktivní odpady: čemu věřit. Třetí pól, 2007(5), pp. 4-5. 
Marek, T. \& Zlémalová, L. \& Fiala, M. (1998, April 25). Stát prohrál boj o vliv v Mostecké uhelné, Mladá fronta DNES, 1998, p. 14.

Marková, L. (1996). Čeho se bojíme: skladování a transportu vyhořelého jaderného paliva? Vesmír, roč. 75(11), pp. 626-629.

Martinec, P.(2009). Landek a geologie hornoslezské pánve - význam těžební lokality pro poznání kraje. Vesmir, 88(6), pp. 396-397.

Mařík, M. (2011). Biomasu kočírujeme. Ekonom, LV (1), p. 13.

Máslo, K., \& Švejnar, P. (2007). Stabilita elektrizační soustavy. Vesmír, 8 (1), pp. 30-32.

Mikeš, L., \& Mikšovský, T. (2008). Paramo Pardubice: Česká rafinérie s nejdelší tradicí. Magazín PETROL, 2008(1), pp. 16-18.

Mikšovský, T. (2003). Stále dokonalejší rafinerie - Vývoj zpracování ropy v českých zemích. Magazín PETROL, 2003(5), pp. 14-18.

Mikšovský, T. (2008). Tomáš Hüner „Domnívám se, že ČEPRO na rozdíl od společnosti MERO ČR je blíž případně možné privatizaci. Magazín PETROL, 2008(4), pp. 20-23.

Ministerstvo průmyslu a obchodu. (2010e). Návrh věcného záměru zákona o Státním fondu povinných zásob ropy a ropných produkt. Praha: MPO.

Ministerstvo průmyslu a obchodu. (2012). Aktualizace Státní energetické koncepce České republiky-srpen 2012. Praha: MPO.

Ministerstvo životního prostředí / Česká geologická služba - Geofond. (2009). Surovinové zdroje České republiky - nerostné suroviny (stav 2008). Praha: Česká geologická služba - Geofond.

Ministerstvo životního prostředí / Česká geologická služba - Geofond. (2010). Surovinové zdroje České republiky - nerostné suroviny (Statistické údaje do roku 2009). Praha: Česká geologická služba - Geofond.

Müller, J. (2002). Operátor trhu s elektřinou, a. s. Česká energetika, 2002(1), pp. 53-55.

Mužík, O., \& Kára, J. (2008). Možnosti výroby a využití bioplynu v ČR. Energie 21, 2008 (1), pp. 22-25.

Myslil, V. (2008a). Možnosti využití geotermální energie v České republice - 1. Energie 21, 2008(3), pp. 32-33.

Myslil, V. (2008b). Možnosti využití geotermální energie v České republice - 2. Energie 21, 2008(4), pp. 32-33.

Myslil, V., Kukal, Z., Pošmourný, K., \& Frydrych, V. (2007). Geotermální energie: ekologická energie z hlubin Země - současné možnosti využívání. Planeta, XV, 2007(4).

Nachmilner, L. (2002). Ukládání jaderného paliva doma a ve světě. Česká energetika, 2002(4), pp. 12-15.

Nečas, P. (2011). Chceme silnou a soběstačnou energetiku, Záznam projevu předsedy vlády Petra Nečase na 11. energetickém kongresu ČR s názvem Energetika čistá a bezpečná dne 29. března. Energetika, 61(4), p. 199-200.

Němeček, T. (1998, May 4). Privatizace? Už byla... Respekt, 1998, p. 6.

Neužil, J. (1995). Česká energetika na začátku roku 1995. Energetika, 1995 (1). 
Noskievič, P. (1995a). Energetické využití černého uhlí a emise škodlivin. Energetika, 1995(2), pp. 55-57.

Noskievič, P. (1995b). K dalšímu vývoji uhelné energetiky. Energetika, 1995(11), pp. 339-341.

Noskievič, P. (1996). Problémy uhelné energetiky. Energetika, 1996(2), pp. 37-40.

Noskievič, P. (2000). Vývojové trendy uhelné energetiky. Magazín Energie, 2000(7-8), pp. 60-63.

Nuclear Energy Agency, \& Organisation for Economic Co-operation and Development: Nuclear Energy Data 2009. (2009). Paris: OECD Publishing.

Obchodování s elektřinou v ČR, zkušenosti, strategie a doporučení. (2002). Česká energetika, 2002 (4), pp. 40-42.

Odborná pracovní skupina pro energetickou bezpečnost Výboru pro koordinaci zahraniční bezpečnostní politiky. (2006, 1. listopad). Zajištění energetické bezpečnosti ČR, stav a riziko realizace hrozeb. Materiál pro Bezpečnostní radu státu.

Organisation for Economic Co-operation and Development. (2009). OECD Economic Outlook, 2009(2). Paris: OECD Publishing.

Organisation for Economic Co-operation and Development Nuclear Energy Agency. (2009). Nuclear Energy Data 2009. Paris: OECD Publications.

Organisation for Economic Co-operation and Development Nuclear Energy Agency / IEAE. (2008). Uranium 2007: Resources, Production and Demand. Paris: OECD Publications.

Organisation for Economic Co-operation and Development /International Energy Agency (2009a). Coal information 2009. Paris: IEA Publications.

Organisation for Economic Co-operation and Development / International Energy Agency. (2009b). Renewables information 2009. Paris: IEA Publications.

Organisation for Economic Co-operation and Development / International Energy Agency. (2010). Energy Policies of IEA Countries - The Czech Republic - 2010 Review. Paris: IEA Publications.

Otčenášek, P. (2005). Odpady z palivového cyklu jaderných elektráren - Zdokonalování technologií, zpř́isňování dozoru a osvěta. Vesmír, 84(9), pp. 536-540.

Otčenášek, P. (2011). Fukušima Daiichi po nadprojektové havárii (odhad). Energetika, 61 (5), pp. 271-272.

Paprskář, J. (2004). Před 85 lety byl schválen první československý energetický zákon. Energetika 2004(10), pp. 313-315.

Petrlík, J. (1991, September 9). Na palubě s Temelínem. Respekt, 1991, p. 8.

Petržilka, O. (2009b, November 19). Proč se nás nedotkla krize dodávek plynu přes Ukrajinu aneb Nebyla to náhoda! Přednáška Ing. Oldřicha Petržilky, prezidenta Česká plynárenská unie, Fakulta Sociálních Studií Masarykovy Univerzity, Brno.

Petržilka, O., \& Kastl, J. (2009). Jaký vliv bude mít „plynová krize“ a ekonomická recese na budoucnost dodávek zemního plynu pro Českou republiku? Pro-Energy magazín, 2009(3), pp. 26-30.

Petržilka, O., \& Kastl, J. (n.d.). Plyn v energetickém hospodářství ČR: Může „plynová krize“ ovlivnit úlohu zemního plynu? Vesmír, 88(3), pp. 160-163. 
Píha, M. (1994). K otázce dezintegrace elektrizační soustavy a vnitřního trhu s elektřinou. Energetika, 1994(3), pp. 69-70.

Píha, M. (1998). Jak dál s privatizací energetiky. Energetika, 1998(7-8), pp. 236 - 237.

Podporuji využívání alternativních zdrojů. (2008). Energie 21, 2008 (2), pp. 8-9.

Pokorný, M. (2003, December 1). Jak se manipuluje za Špidly. Respekt, 2003, p. 8.

Pokorný, M. (2004, November 15). OKD má nového uhlobarona, Respekt, 2004, p. 12.

Poková, E. (1995). Historie jáchymovského uranu. Vesmír, 74(9), p. 504-506.

Porovnání elektráren z hlediska vlivu na životní prostředí.(2007). Třetí pól, 2007(10), p. 14.

Pravda, P. (2011, October 17). Novela energetického zákona. Právo, 2011, p. 39.

Pravec, J. (2011, April 21-27). Nadšení pro jádro slábne. Ekonom, LV(16), pp. 42-45.

Privatizace hnědouhelných firem má být do konce roku, OKD ještě počká. (1997, November 13). Hospodárské noviny, 1997, p. 1.

Prokop, L. (1997). Bude odsiřování účinnější? Vesmír, 76(7), p. 394.

Roškanin, M. (2006). Ropovod IKL nebude otočen. Magazín PETROL, 2006(6), p. 6.

Roškanin, M. (2007a). Na polské geofyziky jsou jen stížnosti: Zlobí se na ně nejen ekologové, ale i Jihomoravané. Magazín PETROL, 2007(2), p. 9.

Roškanin, M. (2007b). Uzavře Rusko ropovod Družba? Česko by mělo problém, odkud ropu brát. Magazín PETROL, 2007(4), pp. 8-9.

Roškanin, M. (2008a). Cenná závislost: Poučí Česko zkušenost s přiškrcením dodávek ropy Družbou? Magazín PETROL, 2008(5), p. 9.

Roškanin, M. (2008b). MND chtějí nová ložiska na Moravě. Magazín PETROL, 2008(2), p. 6.

Roškanin, M. (2008c). MND mají v Rusku problém s ropou. Magazín PETROL, 2008(2), p. 6.

Roškanin, M. (2008d). Slováci chtějí otočit tok v Družbě - Hrozí ukončení přepravy starým ropovodem. Magazín PETROL, 2008(3), p. 7.

Roškanin, M. (2009). Dodávky ropy budou plynulejší - Mero uzavřelo dohodu s ruským přepravcem ropy. Magazín PETROL, 2009(4), p. 6.

Rytír, L. (2008). Kdy nám dojdou zásoby uranu? Třetí pól, 2008(12), pp. 16-17.

Řehoř, M. (2009). Rejstř́ík obchodování s povolenkami na emise skleníkových plynů v roce 2008. Pro-Energy magazín, 2009(1), pp. 61-67.

Sacher, T. (2010). Bude to naše dědictví. Respekt, XXI(7), pp. 36-39.

Sacher, T., Spurný, J. (2009a). Otevřete, jste obklíčeni. Respekt, XX(49), pp. 20-21.

Sacher, T., Spurný, J. (2009b). Zlatý důl od ČEZ. Respekt, XX(51), pp. 18-21.

Sedlák, M. (2009). Za škody ručíme. S omezením. Sedmá generace, XVIII(3), p. 31.

Skřivan, P. (2000). Emise CO2 a Temelín. Vesmír, 12, p. 669. 
Sladký, V. (2009). Efektivní spalování biomasy v kotlích na uhlí a koks. Energie 21, 2009(6), pp. 20-23.

Slezák, J. (2001). Historie těžby uranu v oblasti Stráže pod Ralskem v severočeské křídě a hydrogeologie. In Sborník geologických věd, Hydrogeologie a inženýrská geologie 2001(21) (pp. 5-36), Praha: Český geologický ústav.

Slouka, P. (1995). Výroba a využití technologie zplyňování uhlí pro výrobu elektrické energie. Energetika, 1995(4), pp. 123-125.

Spilka, P., \& Sucharda, J. (2010). Jaderná elektrárna Dukovany včera dnes a zitra. Praha: ČEZ, a. s.

Spurný, J. (2009). Za limity! Respekt, 2009(26).

Spurný, J. \& Kundra, O. (2011, November 20). Jak se kradly doly. Respekt, 2011.

Stabilizace dodávek větrné energie v Německu. Energetika - Průvodce světem energii a jejich úspor, 2011(4), p. 6.

Stehlík, J. (2000). Komentář k Energetické politice ČR. Energetika, 2000(5), pp. 152-156.

Straka, P. (2009). Co je uhlí? Znalost chemické struktury - základ pro dobré využití. Vesmír, 88(6), pp. 404-405.

Strašil, Z., \& Šimon, J. (2008). Využití rostlinné biomasy v energetice ČR. Energie 2, 2008, (3), p. 6-10.

Strašil, Z., \& Šimon, J. (2008). Využití rostlinné biomasy v energetice ČR - 2. Energie 21, 2008 (4), p. 14-15.

Strnad, J., Veselský, P., \& Cahyna, F. (2007). Zahraniční spolupráce elektrizační přenosové soustavy ČR. Vesmír, 86(10), pp. 646-647.

Stupavský, V. (2009, ed.). Biomasa \& Energetika 2009: Energetické a průmyslové rostliny XIV. - Sborník referátů. Praha: Česká zemědělská univerzita v Praze.

Suchý, J. (2007). Emisní obchodování v České republice: novinky z projednávání Národního alokačního plánu II aneb co s povolenkou. Pro-Energy magazín,2007(2), pp. 60-64.

Svoboda, J., \& Svobodová, J. (2008). Uhlíková daň - Podceňovaný nástroj boje proti globální změně klimatu. Vesmír, 87(9), pp. 616-621.

Šafařík, M. (2000). Konkurenceschopnost obnovitelných přírodních zdrojů v nedohlednu? - I. část. Magazín Energie, 2000(5), pp. 62-65.

Šafařík, M. (2000). Konkurenceschopnost obnovitelných přírodních zdrojů v nedohlednu? - II. část. Magazín Energie, 2000(6), pp. 58-61.

Šafaříková, K. \& Němeček, T. (2003, December 22). Šest bohatých pokrytců, polízanice s doly, za Robertem Bartleyem. Respekt, 2003, p. 9.

Šafářová, M. (2009). Uhlí patř́ mezi energetické zdroje budoucnosti. All for power, 3, pp. 73-75.

Šálek, F. (1996). Opatření Státní politiky životního prostředí pro sektor energetiky k minimalizaci negativního vlivu na životní prostředí. Energetika, 1996(3), pp. 73-75.

Š́lek, M. (2004). Rozpočet není Mikuláš. Respekt, 2004, p. 4.

Šindler, P. (2006). Energetické právo v České republice (Nepublikovaná rigorózní práce). Masarykova univerzita. Brno. 
Šolc, P. (2008b). Smíme všichni naráz zhasnout světlo? Vliv spotřebitele na elektrizační soustavu. Vesmír, 87(4), pp. 250-251.

Šrámek, D.(2010). Prolomte těžební limity - David Vodrážka jako zmatený ekologista ODS. Reflex,7, p. 17.

Štěpánek, Z. (1998). Energetika, ekonomika a ochrana ovzduší. Energetika, 1998(1), pp. 7-10.

Štochl, M., \& Čižmář, Z. (2008). Benzina v proměnách času. Praha: Benzina, s. r. o.

Švec, P. (2010, May 14). Lidé v Bohnicích uspěli. Elektrárna se stavět nebude. Mladá Fronta DNES, p. 1.

Švehla, M. (1999a, March 22). Třetí premiér na tahu. Respekt, 1999a, p. 6.

Švehla, M. (1999b, March 29). Jak žít bez Temelína. Respekt, 1999b, p. 5.

Švehla, M. (1999c, May 17). Důchodci za atomové jistoty. Respekt, 1999c, p. 4.

Švehla, M. (2010). Prubírský Prunéřov. Respekt, XXI(3), p. 23.

Teplý, J., Čapská, K. (2004). Odsíření elektrárny Chvaletice. Třetí pól, 2004(4), p. 12.

Těšínská, E., \& Kunz, E. (2006). Státní ústav radiační ochrany a jeho předchůdci. Pohled do historie radiační ochrany v českých zemích. In Drábková, A.(Ed.), Historie radiačni ochrany v ČR. 10 let Státního ústavu radiačni ochrany 1995-2005 (pp. 9-52). Praha: Státní ústav radiační ochrany.

Teyssler, J. (1997). Budoucnost českého hnědého uhlí. Energetika, 1997(5), p. 168.

Toušek, Václav a kol. (2005). Česká republika - portréty krajů. Praha: Ministerstvo pro místní rozvoj ČR.

Trnavský, J. (2008a). Nedostatek potravin nelze svádět jen na biopaliva. Energie 21, 2008(3), pp. 24-25.

Trnavský, J. (2008b). Teplo z obnovitelných zdrojů. Energie 21, 2008 (6), pp. 42-43.

Trnavský, J. (2010). Hlavní rozdíly mezi zemědělskou a komunální bioplynovou stanicí. Energie 21, 2010 (3), pp. $14-15$

Úrad vlády ČR, \& Nezávislá energetická komise. (2008, September 30). Zpráva Nezávislé odborné komise pro posouzeni energetických potřeb České republiky v dlouhodobém časovém horizontu. Praha.

Vaculík, P., Novotný, J., \& Kaláb, M. (2011). Výroba a ř́zení elektrického výkonu z decentrálních obnovitelných zdrojů. Energetika, 61 (5), pp. 287-293.

Valášek, V. (2000a). Hnědé uhlí může plnit úlohu nosného primárního zdroje pro výrobu elektřiny i v dlouhodobé perspektivě - I. Část. Magazin Energie, 2000(9), pp. 61-65.

Valášek, V. (2000b). Hnědé uhlí může plnit úlohu nosného primárního zdroje pro výrobu elektřiny i v dlouhodobé perspektivě - II. Část. Magazín Energie, 2000(10), pp. 49-51.

Valášek, V. (2000c). Úloha uhlí ve struktuře primárních energetických zdrojů v České republice pro rozvoj elektroenergetiky a teplárenství. In Kolektiv autorů, Energetika a životni prostředí IX. - Paliva pro 21. století a 3. Tisíciletí (pp. 10-35). Ústí nad Labem: Dům techniky Ústí, s. r. o.

Vazač, V. (1993a). Energetické hospodářství Československa na začátku 90. Let. Energetika, 1993(5), pp. 153-157.

Vazač, V. (1993b). Př́íspěvek k diskusi o míře nasycenosti Československa 80. let elektrickou energií. Energetika, 1993(6), pp. 194-197. 
Vítek, M. (1994). Útlum, nebo racionalizace těžby uhlí? Energetika, 1994(12), p. 382.

Vlček, T., \& Černoch, F. (2013). Aktuální vývoj ve vybraných hnědouhelných kontraktech v České republice. Energetika, 2013(7), pp. 466-467.

Vlk, V. (2008). Obnovitelné zdroje energie. PRO-ENERGY magazín, 2008(3), pp. 18-21.

Vnouček, S. (2010). Čtyři miliardy ročně? Pokud úřady dovolí - Rozvoj české přenosové soustavy do roku 2020 musí zajistit připojení nových energetických zdrojů včetně obnovitelných. Pro-Energy magazín, 2010(3), pp. 30-33.

Vnouček, S., \& Kasembe, A. G. (2010). Plán rozvoje přenosové soustavy ČR. All for Power, 4(2), pp. 2-3.

Vokroj, J. (2011). Jak je to se zvyšováním hladiny moří - jednoduchý výpočet. Energetika,61(7), p. 445.

Vondráš, J. (2010). Štěpka nebo plyn uhlí nenahradí - Může české teplárenství existovat po roce 2012 bez hnědého uhlí za limity nebo najde nová vláda odvahu řešit blížící se nedostatek tohoto paliva? Pro-Energy magazín, 2010(2), pp. 37-39.

Vrba, M. (1994). Podnikatelské záměry ČEZ, a. s., do roku 2000. Energetika,1994(6), pp. 172-174.

Wanke, R. (1993, February 11). Postavit Temelín je nejhospodárnější varianta. Rudé právo, 1993, p. 8.

Weger, J. (2008). Biomasa jako zdroj energie. Energie 21, 2008(1), pp. 9-11.

Weishauptová, Z.(2008). Uhlí jako úložiště a zdroj plynů. Vesmír, 87(9), pp. 622-623.

Zabo, L. (2008). Nouzové zásoby ropy a ropných produktů zaručují bezpečnost státu. Magazín Pro-Energy, 2008(4), pp. 75-77.

Zajíček, M. (2001a, March 19). Vorlíčkovy velké oči. Respekt, 2001, p. 12.

Zajíček, M. (2001b, October 1). Před skokem do tmy. Respekt, 2001, p. 8.

Zajíček, M. (2001c, October 8). Transgas není ČEZ, Respekt, 2001, p. 9.

Zajíček, M. (2002a, February 11). Víc štěstí než rozumu. Respekt, 2002(7).

Zajíček, M. (2002b, May 13). ČEZ ke štěstí přišel. Respekt, 2002, p. 9.

Zajíček, M. (2003, October 27). Pan SuperČEZ padl. Respekt, 2003, p. 8.

Zajíček, M. (2005, May 16). Čas ukázal, že prodej OKD byl fiaskem. Respekt, 2005, p. 8.

Zajíček, M. (2010). Účet za 700 miliard korun - Ekonomické dopady současného systému podpory fotovoltaických elektráren. Pro-Energy magazín, 2010(3), pp. 62-68.

Zajíček, M., \& Zeman, K. (2010, August). Energie z odpadi̊-(zatím) nevyužitý potenciál. Praha: Oeconomica.

Závěšický, J. (2005). Smlouva o nešíření jaderných zbraní (NPT). In Kuchyňková, P., \& Suchý, P.(Eds.), Vývoj a výsledky procesů kontroly zbrojení a odzbrojování - Marnost nad marnost? (pp. 131-162). Brno: MPÚ.

Zelenka, R. (2011, February 24 - March 2). Temelín si dává načas. Ekonom, LV (8), p. 28.

Zelenka, R., \& Mařík, M. (2011). Další průšvih na obzoru. Ekonom, LV (1), pp. 10-15. 
Zeman, J. (2000). Problémy zavádění trhu s elektřinou a zemním plynem. Magazín Energie, 2000(10), pp. 14-17.

Zeman, J. (2011). Kudy z krize využívání obnovitelných zdrojů energie? Energetika, 61(1), pp. 44-48.

Zlámalová, L. (2003a, June 30). Stát musí být soběstačný. Respekt, 2003, p. 9.

Zlámalová, L. (2003b, October 20). Když levice prodává důl. Respekt, 2003b, p. 3.

Zlámalová, L. \& Němeček, T. (2003, August 4). České doly Čechům, důkazy o koženém a bázlivci proti Nomuře. Respekt, 2003, p. 9.

Žák, V. (2003, August 14). Má to Antonín Koláček jisté? Ekonom, 2003, p. 36.

\section{Electronic Sources}

Adámková, A. (2010b). Jak zabezpečit dodávky zemního plynu? E15 speciál - Energetika, s. II-IV. Retrieved from http://file.mf.cz/748/special-energetika-05-03-10.pdf

Adámková, A. (2010c). Oldřich Petržilka: V Evropě je pro plyn př́znivá situace. E15 speciál - Energeti$k a$, s. 5-6. Retrieved from http://file.mf.cz/748/special-energetika-05-03-10.pdf

Akrman, L. (2009, 12. listopad). Česko je připraveno na plynovou krizi. Zásobníky jsou plné a plné i zůstanou. Hospodářské noviny. Retrieved from http://ekonomika.ihned.cz/c1-39053530-cesko-je-pripravenona-plynovou-krizi-zasobniky-jsou-plne-a-plne-i-zustanou

Anketa Ropák \& Zelená perla. (n.d.). Retrieved from http://www.ropak.detizeme.cz/

AREVA. (2011). 2010 Reference document. Retrieved from http://www.areva.com/mediatheque/liblocal/ docs/pdf/groupe/pdf-doc-ref-10-va.pdf

Baroch, P. (2011a, March 3). Stát chce přestat chránit obce za těžebními limity. Aktuálně.cz. Retrieved from http://aktualne.centrum.cz/

Baroch, P. (2011b, March 10). Zbourat vsi kvůli uhlí? Státní komise měla jasno předem. Aktuálně.cz. Retrieved from http://aktualne.centrum.cz/

Bártek, P. (2010, June). Makroekonomický pohled na současný stav těžebního průmyslu ČR. Prezentace na konferenci Těžba uhlí v ČR: alternativy budoucího vývoje, Praha. Retrieved from http://www.ivd.cz/ cs/energeticka_bezpecnost_cr/tezba_uhli_cr_alternativy_budouciho_vyvoje

Bartuška: Plynové elektrárny jen zvyšují závislost na Rusku. (2010, March 23). Lidovky.cz. Retrieved from http://byznys.lidovky.cz/bartuska-plynove-elektrarny-jen-zvysuji-zavislost-na-rusku-p51-/statni-pokladna.asp?c=A100323_154216_statni-pokladna_nev

Bednář, P., Bufka, A., \& Rosecký, D. (2010, April). Kombinovaná výroba elektřiny a tepla v roce 2008: výsledky statistického zjištování. Retrieved from http://download.mpo.cz/get/41312/46101/555531/priloha001.pdf

Beneš, I. a kol. (2007). Energetická bezpečnost - informační př́íručka. Projekt Ministerstva průmyslu a obchodu 2A-1TP1/065. Retrieved from www.cityplan.cz/index.php?id_document=963

BENZINA, s. r. o. Retrieved from http://www.benzinaplus.cz/ 
Beran, A. (2006). Tuhá paliva. Retrieved from http://download.mpo.cz/get/26709/27922/308625/priloha001.pdf

Bez zisku vydržíme i deset let řiká spolumajitel Czech Coalu. (2012a, March 22). Ekonom. Retrieved from http://byznys.ihned.cz/c1-55152640-bez-zisku-vydrzime-i-deset-let

Bilance elektrické energie v letech 1993 až 2007 v GWh. (n.d.). Retrieved from http://notes3.czso.cz/ csu/2008edicniplan.nsf/t/A3002DE59D/\$File/81100801.pdf

Bochníček, Z. (2006). Jaderná energetika: rizika a alternativy. Retrieved from http://sf.zcu.cz/rocnik06/ cislozv/bochnic.html

Bratislava-Schwechat pipeline drafts. (2011, May 30). The Slovak Spectator. Retrieved from http://spectator.sme.sk/

Brusel udělil EPH pokutu ve výši 60 milionů korun. (2012, March 28). Týden. Retrieved from http://www. tyden.cz/rubriky/byznys/cesko/brusel-udelil-eph-pokutu-ve-vysi-60-milionu-korun_229534.html

Břešt’an, R. (2007, April 23). Atom, či zelená energie? Vládě napoví komise. Hospodářské noviny. Retrieved from http://hn.ihned.cz/index.php?p=500000_d\&article[id] $=20966620$

Burza cenných papírů Praha, a. s. (2011). Ročenka 2010 / Fact Book 2010 - Power Exchange Central Europe, a. s., s. 34-43. Retrieved from http://www.pxe.cz/pxe_downloads/Statistics/Year/fb2010.pdf

Business Monitor Online. (2010). Gassco To Upgrade Kårstø Gas Plant. Retrieved from http://www.allbusiness.com/energy-utilities/oil-gas-industry-oil-processing/14308722-1.html

Ciarreta, A., \& Nasirov, S.(2010). Impact of Azerbaijan's Energy Policy on the Development of the Oil Sector. International Association for Energy Economics, 2010, Fourth Quarter, pp. 43-46. Retrieved from $\mathrm{http}: / / \mathrm{www}$. iaee.org/en/publications/newsletterdl.aspx?id=118

Cieslar, S. (2008a, June 4). Centrální tankoviště ropy v Nelahozevsi rozšíŕily dva obří zásobníky ropy. Konstrukce - Odborný časopis pro stavebnictví a strojírenství. Retrieved from http://www.konstrukce.cz/

Cieslar, S. (2008b, November 30). Teplárenské sdružení chce prolomit těžební limity na hnědé uhlí. All for Power. Retrieved from http://www.allforpower.cz/clanek/teplarenske-sdruzeni-chce-prolomit-tezebni-limity-na-hnede-uhli/

Cieslar, S. (2009, June 18). Do elektrizační sítě ČR přiteče do roku 2020 kolem 180 miliard korun. All for Power. Retrieved from http://www.allforpower.cz/clanek/do-elektrizacni-site-cr-pritece-do-roku-2020kolem-180-miliard-korun/

Cieslar, S. (2010b, September 27). „Mezi lety 2013 až 2020 se bude jedna třetina povolenek některým společnostem přidělovat zdarma“" uvedl v rozhovoru pro časopis All for Power Mgr. Pavel Drobil, ministr životního prostředí ČR (MŽP). All for Power. Retrieved from http://www.allforpower.cz/clanek/mezi-lety-2013-az-2020-se-bude-jedna-tretina-povolenek-nekterym-spolecnostem-pridelovat-zdarma/

Cieslar, S. (2010c, April 9). „Problém s integrací obnovitelných zdrojů mají i jinde. Snižují se dotace, sluneční a větrné elektrárny se vypojují ze sítě“ uvedl v rozhovoru pro časopis All for Power Ing. Petr Zeman, předseda představenstva a generální ředitel ČEPS, a. s. All for Power. Retrieved from http://www. allforpower.cz/clanek/problem-s-integraci-obnovitelnych-zdroju-maji-i-jinde-snizuji-se-dotace-slunecni-a-vetrne-elektrarny-se-vypojuji-ze-site/

Cieslar, S. (2010d, May 26). RWE Gas Storage zahájila práce na rozšíření zásobníku. All for Power. Retrieved from http://www.allforpower.cz/clanek/rwe-gas-storage-zahajila-prace-na-rozsireni-zasobniku/ 
Cieslar, S. (2010e, August 19). „Zlepšujeme využití jaderného paliva,“ uvedl v rozhovoru pro časopis All for Power Ing. Tomáš Žák, ředitel Jaderné elektrárny Dukovany. All for Power. Retrieved from http:// www.allforpower.cz/clanek/zlepsujeme-vyuziti-jaderneho-paliva/

Cook, J. (2010). Vědecký průvodce skepticismem vi̊či globálnímu oteplování. Retrieved from http://www. skepticalscience.com/docs/Guide_Skepticism_Czech.pdf

Commission of the European Communities. (1995, May 3). White Paper on Preparation of the Associated Countries of Central and Eastern Europe for Integration into the Internal Market of the Union. Retrieved from http://aei.pitt.edu/1120/1/east_enlarg_wp_COM_95_163.pdf

Co stoji za razií, za kterou zaplatí EPH pokutu? Válka o uhlí mezi ČEZ a Tykačem. (2012, March 28). Hospodárské noviny. Retrieved from http://byznys.ihned.cz/zpravodajstvi-cesko/c1-55207540-costoji-za-razii-za-kterou-zaplati-eph-pokutu-valka-o-uhli-mezi-cez-a-tykacem

Council Directive 2004/67/EC of 26 April 2004 concerning measures to safeguard security of natural gas supply. Retrieved from http://eur-lex.europa.eu/smartapi/cgi/sga_doc?smartapi!celexplus!prod!DocNumber\&lg $=$ en\&type_doc $=$ Directive\&an_doc $=2004 \& n u \_d o c=67$

Czech Republic: Oil pipeline to Vienna-Schwechat? (2010, August 19). wieninternational.at. Retrieved from http://www.wieninternational.at/en

Czech Coal Group. Retrieved from http:/www.czechcoal.cz/cs/index.html

Czech Coal Group. (2012). Roční zpráva skupiny Czech Coal: Hospodaření a udržitelný rozvoj v roce 2011. Available at http://www.czechcoal.cz/

Czech Coal poskytl Evropské komisi podklady pro vyšetřováni ČEZ. (2011, August 9). Hospodářské noviny. Retrieved from http://byznys.ihned.cz/zpravodajstvi-evropa/c1-52539110-czech-coal-poskytl-evropske-komisi-podklady-pro-vysetrovani-cez

Čarek, M. (2009, October 26). Lukoil chce koupit rafinerie v Německu a produkty prodávat do Polska. Mediafax.cz. Retrieved from http://www.mediafax.cz/ekonomika/2947685-Lukoil-chce-koupit-rafinerie-v-Nemecku-a-produkty-prodavat-do-Polska

Čech, M., \& Tichý, T. (2001). 30 úspěšných let: Transgas 1971-2001. Plyn, 2001(3). Retrieved from http://www.energetik.cz/hlavni3.html?m1=/clanky/pl_2001_3_2.html

ČEPRO, a. s. Retrieved from http://www.ceproas.cz/

ČEPRO, a. s. (n.d.). Produktovodní sít’ a střediska. Retrieved from http://www.ceproas.cz/

ČEPRO, a. s. (2010). Výroční zpráva 2009. Retrieved from http://www.ceproas.cz/

ČEPRO, a. s. (2011). Výroční zpráva 2010. Retrieved from http://www.ceproas.cz/

ČEPS, a. s. Retrieved from http://www.ceps.cz/

ČEPS, a. s. (n.d.) Většina akcií společnosti ČEPS převedena na MPO. Retrieved from http://www.ceps.cz/ $\mathrm{cz} /$ zpravy/zobrazTSK.asp?ID $=318$

ČEPS, a. s. (2009). Schéma přenosové soustavy ČR, stav k 1. 1. 2009. Retrieved from http://www.ceps.cz/ doc/soubory/Internet_16_10_2008/schema_siti_1_1_2009.pdf

ČEPS, a. s. (2010a). Podpůrné služby. Retrieved from http://www.ceps.cz/detail.asp?cepsmenu=4\&ID$\mathrm{P}=43 \& \mathrm{PDM} 2=209 \& \mathrm{PDM} 3=0 \& \mathrm{PDM} 4=0$ 
ČEPS, a. s. (2010b). Provoz a ř́zení - Údaje o PS. Retrieved from http://www.ceps.cz/detail.asp?ceps$\mathrm{menu}=3 \& \mathrm{IDP}=32 \& \mathrm{PDM} 2=0 \& \mathrm{PDM} 3=0 \& \mathrm{PDM} 4=0$

ČEPS, a. s. (2010c). Roční př́prava provozu na rok 2011. Retrieved from http://www.ceps.cz/doc/soubory/20101203/RPP_2011.pdf

ČEPS, a. s. (2010d). Výroční zpráva 2009. Retrieved from http://www.ceps.cz/doc/soubory/20100514/ CEPS_Vyrocni_zprava_\%202009.pdf

ČEPS, a. s. (2011). Kodex přenosové soustavy (Revize 11 ve znění schváleném ERÚ k 1.1.2011). Retrieved from http://www.ceps.cz/detail.asp?IDP=61\&PDM4=0\&PDM3=0\&PDM2=0\&cepsmenu=5

ČEPS, a. s. (2013). Roční př́prava provozu na rok 2013. Retrieved from http://www.ceps.cz/CZE/Cinnosti/Dispecerske_rizeni/Priprava_provozu/Documents/RPP_2013.pdf

ČEZ, a. s. (n.d.). 90. léta - program ,vyčištěni" uhelných zdrojů. Retrieved from http://www.cez.cz/cs/ vyroba-elektriny/uhelne-elektrarny/strategie-a-aktivity-cez-v-oblasti-ue.html

$\check{C} E Z$, a.s. (n.d.). Energetika $v \check{C} R$. Retrieved from http://www.cez.cz/cs/pro-media/cisla-a-statistiky/energetika-v-cr.html

ČEZ, a.s. (2011a): Zátěžové testy JE - ČEZ, a.s., Ocenění bezpečnosti a bezpečnostních rezerv JE Dukovany (z pohledu skutečností havárie na JE Fukushima). Retrieved from http://www.cez.cz/edee/content/ file/energie-a-zivotni-prostredi/dukovany/zaverecna-zprava-zt-edu.pdf

ČEZ, a.s. (2011b): Zátěžové testy JE - ČEZ, a.s., Ocenění bezpečnosti a bezpečnostních rezerv JE Temelín (z pohledu skutečností havárie na JE Fukushima). Retrieved from http://www.cez.cz/edee/content/ file/energie-a-zivotni-prostredi/temelin/zaverecna-zprava-zt-ete.pdf

ČEZ vyřadil Arevu z tendru na Temelín. Elektrárnu dostaví Rusové nebo Američané. (2012, October 5) iHned.cz. Retrieved from http://byznys.ihned.cz/c1-57777360-cez-vyradil-arevu-z-tendru-na-temelin-elektrarnu-dostavi-rusove-nebo-americane

Černoch, F. (2011). Energetická politika EU a energetické zájmy ČR (Unpublished dissertation). Masarykova univerzita. Brno.

Černoch, F. \& Kovačovská, J. \& Ocelík, P. \& Osička, J. \& Vlček, T. \& Zapletalová, V. (2010). Energetická bezpečnost ČR a budoucnost energetické politiky EU. Retrieved from http://www.mzv.cz/file/652093/ Studie_RM01_02_10.pdf

Černoch, F. \& Zapletalová, V., \& Vlček, T. (2010). Energetická politika ČR v rozhodování politických stran: agregace a artikulace zájmů z hlediska jejich intenzity a konzistence. SEPS - Středoevropské politické studie, 12(4), pp. 255-284. Retrieved from http://www.cepsr.com/

Česenek, V. (2007, November). Porovnání jednotlivých obnovitelných zdrojů energie ve vztahu k elektrické síti. In Sborník konference ČK CIRED 2007, Tábor 6, pp. 1-10. Retrieved from http://www.litovany.ic.cz/index_soubory/down/s4_03.pdf

Česká asociace petrolejářského průmyslu a obchodu. (2010). Výroční zpráva 2009. Retrieved from http:// www.cappo.cz/

Česká geologická služba. Retrieved from http://www.geology.cz/

Česká informační agentura životního prostředí. (2011, November 8). Produkce a nakládání s komunálním odpadem - vyhodnocení indikátoru. Retrieved from http://issar.cenia.cz/issar/page.php?id=1612 
Česká plynárenská unie posiluje svůj vliv. (2010, April 22). E15.cz. Retrieved from http://www.e15.cz/ Česká plynárenská unie. Retrieved from http://www.cpu.cz/

Česká plynárenská unie. (n.d.). Využívání zemního plynu v dopravě. Retrieved from http://www.cpu.cz/ Česká plynárenská unie. (2006). Informační materiál - Zemní plyn pro Českou republiku. Retrieved from http://www.cpu.cz/

Česká plynárenská unie. (2007). Zemní plyn - bezpečnost a spolehlivost dodávek. Retrieved from http:// www.cpu.cz/

Česká plynárenská unie. (2009a). Plynové zásobniky máme plné. Retrieved from http://www.cpu.cz/

Česká plynárenská unie. (2009b). Zásobníky plynu by do roku 2013 měly pokrýt polovinu spotřeby ČR. Retrieved from http://www.cpu.cz/

Česká plynárenská unie. (2010a). EU přidělila dotaci na rozšǐreni zásobnikůa a výstavbu plynovodi̊ v České republice. Retrieved from http://www.cpu.cz/

Česká plynárenská unie. (2010b). Spotreba zemního plynu v roce 2009 klesla jen o 6 procent. Retrieved from http://www.cpu.cz/

Česká plynárenská unie. (2010c). Vemex s desetinou trhu se stal členem České plynárenské unie. Retrieved from http://www.cpu.cz/

Česká plynárenská, a. s. Retrieved from http://www.ceskaplynarenska.cz/

Česká rafinérská, a. s. Retrieved from http://www.ceskarafinerska.cz/

Česká rafinérská, a. s. (n.d.). Přepracovací rafinérie. Retrieved from http://www.ceskarafinerska.cz/cz/ index.aspx

Česká rafinérská vypověděla smlouvu o přepravě ropy firmě MERO. (2009, December 11). Svět průmys$l u$. Retrieved from http://www.svetprumyslu.cz/ceska-rafinerska-vypovedela-smlouvu-o-preprave-ropy-firme-mero-ah641/

Česká rafinérská, a. s. (2009). Výroční zpráva 2008. Retrieved from http://www.ceskarafinerska.cz/cz/ index.aspx

Česká rafinérská, a. s. (2010). Výroční zpráva 2009. Retrieved from http://www.ceskarafinerska.cz/cz/ index.aspx

Česká rafinérská, a. s. (2011). Výroční zpráva 2010. Retrieved from http://www.ceskarafinerska.cz/cz/ index.aspx

Česká republika - Státní energetická inspekce. Retrieved from http://www.cr-sei.cz/

Česká republika zatím Kjótský protokol plní s rezervou. (2009, December 7). České noviny - zpravodajský server $\check{C} T K$. Retrieved from http://www.ceskenoviny.cz/zpravy/ceska-republika-zatim-kjotsky-protokol-plni-s-rezervou/410282

Česká společnost pro větrnou energii. (2011). Aktuální instalace. Retrieved from http://www.csve.cz/ clanky/aktualni-instalace-vte-cr/120

Česko vyvezlo rekordně elektřiny. (2010, December 16). Hospodářské noviny. Retrieved from http:// hn.ihned.cz/c1-40569650-cesko-vyvezlo-rekordne-elektriny 
Českomoravská komoditní burza Kladno. Retrieved from http://www.cmkbk.cz/

Český hydrometeorologický ústav. Retrieved from http://www.chmi.cz/

Český hydrometeorologický ústav. (2010). Emise hlavnich znečištujících látekv České republice podle krajů, REZZO 1-4 2007 souhrnně. Retrieved from http://90.183.101.73/uoco/emise/embil/07embil/07r14.html

Český plynárenský svaz. Retrieved from http://www.cgoa.cz/cs/

Český statistický úřad. Retrieved from http://www.czso.cz/

Český statistický úřad. (2008). Spotřeba paliv a energií v členění podle odvětví. Retrieved from http://vdb. czso.cz/vdbvo/tabparam.jsp?voa=tabulka\&cislotab=ENE0030UU\&\&kapitola_id=34

Český statistický úřad. (2009). Tab. 1A Bilance zdrojové části zpracování ropy v ČR - od počátku roku 2006, 2007 a 2008. Retrieved from http://www.czso.cz/csu/2009edicniplan.nsf/t/6A00335486/\$File/81121201a.xls

Český statistický úřad. (2011a). Primární produkce uhlí a lignitu. Retrieved from http://apl.czso.cz/ode/ tab/ten00077.htm

Český statistický úřad. (2011b, September 30). Transformační procesy v energetice v roce 2010. Retrieved from http://www.czso.cz/csu/2011edicniplan.nsf/p/8110-11

ČEZ, a. s. (n.d.a). Jaderné elektrárny ČEZ. Retrieved from www.cez.cz

ČEZ, a. s., (n.d.b). JE Temelín - Hlavní technické údaje. Retrieved from http://www.cez.cz/

ČEZ, a. s. (n.d.c). Program ekologizace. Retrieved from www.cez.cz

ČEZ, a. s. (n.d.d). Správa vyhořelého jaderného paliva. Retrieved from www.cez.cz

ČEZ, a. s. (n.d.e). Uhelné elektrárny v ČR. Retrieved from www.cez.cz

ČEZ, a. s. (n.d.f). Výroční zpráva Skupiny ČEZ za rok 2008. (2009). Retrieved from http://www.cez.cz

ČEZ, a. s. (n.d.g). Významná data z historie české elektroenergetiky. Retrieved from http://www.cez.cz/cs/ vyzkum-a-vzdelavani/pro-zajemce-o-informace/historie-a-soucasnost/vyznamna-data.html

ČEZ, a. s. (n.d.h). Aktivity a strategie Skupiny ČEZ. 90. léta - program „vyčištěni“ “ uhelných zdrojů. Retrieved from http://www.cez.cz/cs/vyroba-elektriny/uhelne-elektrarny/strategie-a-aktivity-cez-v-oblasti-ue.html

ČEZ, a. s. (n.d.i.). Historie a současnost Elektrárny Temelín. Retrieved from http://www.cez.cz/cs/vyroba-elektriny/jaderna-energetika/jaderne-elektrarny-cez/ete/historie-a-soucasnost.html

ČEZ, a. s. (n.d.j.). Profil společnosti Severočeské doly, a. s. Retrieved from http://www.cez.cz/cs/o-spolecnosti/skupina-cez/spolecnosti-skupiny-cez-v-cr/severoceske-doly.html

ČEZ, a. s. (2005, March 11). Vnitřní informace. Retrieved from http://www.cez.cz/cs/pro-investory/informacni-povinnost/793.html

ČEZ, a. s. (2009a). ČEZ zahájil veřejnou zakázku na dodavatele jaderných bloki̊. Retrieved from http:// www.cez.cz/cs/pro-investory/informacni-povinnost/1243.html

ČEZ, a. s. (2009b, February 25). Severočeské doly a skupina J\&T podepsaly smlouvu o akvizici dolů MIBRAG. Retrieved from http://www.cez.cz/cs/pro-investory/informacni-povinnost/1188.html 
ČEZ, a. s. (2010b). Struktura akcionářů. Retrieved from http://www.cez.cz

ČEZ, a. s. (2011a). Fotovoltaické elektrárny ČEZ Obnovitelné zdroje. Retrieved from http://www.cez. cz/cs/o-spolecnosti/skupina-cez/spolecnosti-skupiny-cez-v-cr/cez-obnovitelne-zdroje/fotovoltaicke-elektrarny.html

ČEZ, a. s. (2011b). Jak funguje jaderná elektrárna. Retrieved from www.cez.cz

ČEZ, a. s. (2011c). Připravované projekty paroplynových elektráren ČEZ. Retrieved from http://www.cez.cz ČSSD. (2002). Volební program ČSSD 2002. Retrieved from http://www.cssd.cz/data/files/volebni_program_cssd_2002.pdf

ČSSD. (2006). Volební program ČSSD pro volby 2006 - Jistoty a prosperita. Retrieved from http://www. volby-2006.cz/pdf/volebni_program_CSSD.pdf

ČSSD. (2007). Topolánkova vláda tápe v energetické politice. Retrieved from http://www.cssd.cz/media/ tiskove-zpravy/2007-03-15-topolankova-vlada-tape-v-energeticke-politice-pdf/

ČSSD. (2009a). ČSSD vyzývá vládu k urychlenému řešení energetické bezpečnosti ČR. Retrieved from http://www.cssd.cz/media/tiskove-zpravy/2009-01-30-cssd-vyzyva-vladu-k-urychlenemu-reseni-energeticke-bezpecnosti-cr-pdf/

ČSSD. (2009b). Jistota - program pro rok 2009. Retrieved from http://www.cssd.cz/data/files/programova_brozura_el.verze-2009.pdf

ČSSD. (2010). Velký volební program ČSSD pro volby 2010 - Program změny a naděje. Retrieved from http://www.cssd.cz/soubory/ke-stazeni/dokumenty/velky_volebni_program.pdf

ČT24. (2009, February 18). Bursík hrozi odchodem z koalice, poslanci mu neschválili novelu. Retrieved from http://www.ceskatelevize.cz/ct24/domaci/45941-bursik-hrozi-odchodem-z-koalice-poslanci-mu-neschvalili-novelu/

ČT24. (2010, July 14). Interview s Martinem Kocourkem. Retrieved from http://www.mpo.cz/dokument76633.html

ČT24. (2012, January 29) Česko loni vyvezlo rekordní množství elektřiny. Retrieved from http://www. ceskatelevize.cz/ct24/ekonomika/162458-cesko-loni-vyvezlo-rekordni-mnozstvi-elektriny/

ČTK. (2011a, May 23). LN: Zátěžové testy jaderných elektráren si ČR udělá sama. Finanční noviny.cz. Retrieved from http://www.financninoviny.cz/

ČTK. (2011b, December 3). Moje vláda prolamovat limity těžby hnědého uhlí nebude, slíbil Nečas. Hospodář́sé noviny. Retrieved from http://byznys.ihned.cz/

Daniel, P. (2010, November 30). NWR převzetí polského dolu Bogdanka nevyšlo. E15.cz. Retrieved from http://www.e15.cz/

Dejmal, I., \& Říha, M., \& Marek, J. \& Pakosta, P. (2005). Rekapitulace a závěr. In Říha, M. a kol. (Eds.), Územni ekologické limity těžby v SHP je třeba zachovat jako trvalé a uchránit zbytek sídel a krajiny i obyvatelstvo před dalši devastací aneb z krajiny těžby vytvořme znovu krajinu domova (pp. 45-51). Retrieved from http://files.koreny.cz/200000838-e04c8e146a/Kniha_limity_2005.pdf

DIAMO, státní podnik Stráž pod Ralskem. Retrieved from http://www.diamo.cz/

DIAMO s. p. (2010). DIAMO, státni podnik výroční zpráva 2009. Retrieved from http://www.diamo.cz/ 
Directive 2001/77/EC of the European Parliament and of the Council of 27 September 2001 on the promotion of electricity produced from renewable energy sources in the internal electricity market. Retrieved from http://eur-lex.europa.eu/LexUriServ/LexUriServ.do?uri=CELEX:32001L0077:EN:HTML

Directive 2003/30/EC of the European Parliament and of the Council of 8 May 2003 on the promotion of the use of biofuels or other renewable fuels for transport. Retrieved from http://eur-lex.europa.eu/LexUriServ/LexUriServ.do?uri=CELEX:32003L0030:EN:HTML

Directive 2003/54/EC of the European Parliament and of the Council of 26 June 2003 concerning common rules for the internal market in electricity and repealing Directive 96/92/EC. (2003, July 15). Retrieved from http://eur-lex.europa.eu/LexUriServ/LexUriServ.do?uri=CELEX:32003L0054:EN:HTML

Directive 2003/55/EC of the European Parliament and of the Council of 26 June 2003 concerning common rules for the internal market in natural gas and repealing Directive 98/30/EC. Retrieved from http:// eur-lex.europa.eu/LexUriServ/LexUriServ.do?uri=CELEX:32003L0055:en:NOT

Directive 2006/32/EC of the European Parliament and of the Council of 5 April 2006 on energy end-use efficiency and energy services and repealing Council Directive 93/76/EEC. Retrieved from http://eur-lex. europa.eu/LexUriServ/LexUriServ.do?uri=OJ:L:2006:114:0064:0064:en:pdf

Directive 2009/28/EC of the European Parliament and of the Council of 23 April 2009 on the promotion of the use of energy from renewable sources and amending and subsequently repealing Directives 2001/77/EC and 2003/30/EC. Retrieved from http://eur-lex.europa.eu/LexUriServ/LexUriServ.do?uri=O$\mathrm{J}: \mathrm{L}: 2009: 140: 0016: 01: \mathrm{EN}: H T M L$

Directive 2009/73/EC of the European Parliament and of the Council of 13 July 2009 concerning common rules for the internal market in natural gas and repealing Directive 2003/55/EC. Retrieved from http:// eur-lex.europa.eu/LexUriServ/LexUriServ.do?uri=OJ:L:2009:211:0094:0136:EN:PDF

Directive 96/92/EC of the European Parliament and of the Council of 19 December 1996 concerning common rules for the internal market in electricity. (1997, January 30). Retrieved from http://eur-lex.europa. eu/LexUriServ/LexUriServ.do?uri=CELEX:31996L0092:EN:HTML

Directive 98/30/EC of the European Parliament and of the Council of 22 June 1998 concerning common rules for the internal market in natural gas, Official Journal L 204, 21/07/1998, P. 0001 - 0012. Retrieved from http://eur-lex.europa.eu/LexUriServ/LexUriServ.do?uri=CELEX:31998L0030:EN:HTML

Dohoda EU o klimatu je ohrožena. (2008, October 15). Hospodářské noviny. Retrieved from http://ekonomika.ihned.cz/c1-29044810-dohoda-eu-o-klimatu-je-ohrozena

Dolejší, V. Frouzová, K. (2011, January 11). Nový ministr Chalupa: puntičkář a klausovec, který ekologii neholduje. Zprávy.idnes.cz. Retrieved from http://zpravy.idnes.cz/novy-ministr-chalupa-puntickar-aklausovec-ktery-ekologii-neholduje-1jl-/domaci.aspx?c=A110111_1512479_domaci_jj

Doprava a skladování ropy. (n.d.). Petroleum.cz. Retrieved from http://www.petroleum.cz/index.aspx

Dufková, M. (2010). Co ten Prunéřov? Kouří? Kouřri? Retrieved from http://www.tretipol.cz/877-co-tenprunerov-kouri-kouri

E.ON Česká republika, s. r. o. Retrieved from http://www.eon.cz/

E.ON. (n.d.a). Jak funguje elektrárna na biomasu. Retrieved from http://www.eon.cz/file/cs/info/el_power/E.ON-biomasa.pdf 
E.ON. (n.d.b). Jak funguje plynová elektrárna. Retrieved from http://www.eon.cz/file/cs/info/el_power/E. ON-plynova_elektrarna.pdf

Economic Recovery: Second batch of 4-billion-euro package goes to 43 pipeline and electricity projects. (2010, March 4). Retrieved from http://www.rwe-gasstorage.cz/cs/media/EEPR_en.pdf

Economy Watch. Retrieved from http://www.economywatch.com/

EČS a ČEPS podepsaly smlouvu o budoucím připojení plánované elektrárny k přenosové soustavě. (2011, January 20). Retrieved from http://www.rwe.cz/cs/tiskove-zpravy-8896/

Egger, R., \& Schweiger, G. (2011, May 12). Česká republika nechce jednotné zátěžové testy pro jaderné elektrány. Econnect zpravodajství. Retrieved from http://zpravodajstvi.ecn.cz/index.stm

Elektrárna Vřesová bude pojistkou proti blackoutu. (n.d.). Retrieved from http://www.suas.cz/article/ show/id/155

Elektroenergetika. Studijní text kurzu Základy elektroinženýrství Fakulty elektrotechnické Západočeské univerzity v Plzni. Retrieved from http://zcu.yc.cz/TD/ZEI.doc/

Elektroenergetika I (n.d.). Retrieved from http://www.vpicha.cz/sites/default/files/Elektroenergetika \%20I.pdf

Emisní povolenky pro ČEZ zdarma? Rozhodne sněmovna. (2009, June 10). Hospodářské noviny. Retrieved from http://byznys.ihned.cz/c1-37401840-emisni-povolenky-pro-cez-zdarma-rozhodne-snemovna

Energetická politika České republiky (schválená usnesením vlády České republiky ze dne 12. ledna 2000 c. 50). Retrieved from http://biom.cz/leg/Energeticka_politika.doc

Energetický a průmyslový holding nejspíš získá polský důl Silesia. (2010, May 28). ČT24. Retrieved from http://www.ct24.cz/

Energetický a prưmyslový holding. Retrieved from http://www.epholding.cz/ep-energy

ENERGETICKÝ A PRŮMYSLOVÝ HOLDING. (2010, December 9). ENERGETICKÝ A PRU゚MYSLOVÝ HOLDING převzal důl Silesia v Polsku. Retrieved from http://www.epholding.cz/energeticky-a-prumyslovy-holding-prevzal-dul-silesia-v-polsku

Energetický a průmyslový holding se zajímá o další velkou polskou firmu. (2011, February 1). Retrieved from http://www.motejlek.com/page/3?s=eph\&search_x=0\&search_y $=0$

Energetický regulační úřad. (2005). Zpráva o postupu stanovení základních parametrů regulačního vzorce pro II. regulačni období. Retrieved from http://www.eru.cz/user_data/files/matodika \%20regulace/elektro/Zpr \%C3 \%A1va \%20II \%20RO_\%20E.pdf

Energetický regulační úřad. (2008). Charakteristika plynárenství v České republice. Retrieved from http:// www.eru.cz/user_data/files/plyn/40_statistika/charakteristika.pdf

Energetický regulační úřad. (2009a). Bilance elektřiny ES ČR za leden až prosinec [GWh]. Retrieved from http://www.eru.cz/user_data/files/statistika_elektro/rocni_zprava/2008/energie/4.htm

Energetický regulační úřad. (2009b). Roční zpráva o provozu ES ČR za rok 2008. Retrieved from http:// www.eru.cz/user_data/files/statistika_elektro/rocni_zprava/2008/index.htm 
Energetický regulační úruad. (2009c). Závěrečná zpráva ERÚ o metodice regulace III. regulačního obdobi. Retrieved from http://www.eru.cz/user_data/files/prezentace_III_RO/Zaverecna_zprava_o_metodice_\%20III_RO.pdf

Energetický regulační úr̆ad. Retrieved from http://www.eru.cz/

Energetický regulační úr̆ad. (2010a). Cenové rozhodnutí Energetického regulačního úřadu č. 2/2010 ze dne 8. listopadu 2010, kterým se stanovuje podpora pro výrobu elektřiny z obnovitelných zdroju energie, kombinované výroby elektřiny a tepla a druhotných energetických zdroj. Retrieved from http://www.eru. cz/user_data/files/cenova \%20rozhodnuti/CR \%20elektro/2_2010_OZE-KVET-DZ \%20final.pdf

Energetický regulační úřad. (2010b). Roční zpráva o provozu ES ČR 2009 - ERÚ. Retrieved from http:// www.eru.cz/user_data/files/statistika_elektro/rocni_zprava/2009/index.htm

Energetický regulační úr̆ad. (2010c). Vyhodnocení celkové dodávky ze zdrojů zemního plynu v ČR v jednotlivých letech. Retrieved from http://www.eru.cz/dias-read_article.php?articleId=893

Energetický regulační úřad. (2011a). Měsiční zpráva o provozu - prosinec 2010. Retrieved from http:// www.eru.cz/user_data/files/statistika_elektro/mesicni_zpravy/2010/prosinec/obsah.htm

Energetický regulační úřad. (2011b). Oznámení o vyhodnocení podílu výroby elektřiny z obnovitelných zdrojů na hrubé spotřebě elektřiny a o očekávaném dopadu podpory výroby elektřiny z obnovitelných zdroji̊ na celkovou cenu elektřiny pro konečné zákazniky. Retrieved from http://eru.cz/user_data/files/ sdeleni_elektro2/Podil \%20OZE \%202010_final.pdf

Energetický regulační úřad. (2011c). Působnost ERÚv čase. Retrieved from http://www.eru.cz/dias-read article.php?articleId=12

Energetický regulační úřad. (2011e). Vyhodnocení cen tepelné energie $k$ 1. lednu 2011. Retrieved from http://www.eru.cz/user_data/files/Statistika \%20teplo/vyhodnoceni \%20cen/Vyhodnoceni \%20cen \%20 TE \%20k\%201_1_2011.pdf

Energetický regulační úřad. (2011f). Roční zpráva o provozu ES ČR za rok 2010. Retrieved from http:// eru.cz/user_data/files/statistika_elektro/rocni_zprava/2010/rz/index.htm

Energetický regulační úřad. (2012). Roční zpráva o provozu ES ČR za rok 2011. Retrieved from http:// www.eru.cz/user_data/files/statistika_elektro/rocni_zprava/2011/Rocni_zprava_ES_CR_FINAL.pdf

Energetický regulační úřad. (2013). Roční zpráva o provozu ES ČR 2012. Praha: Oddělení statistik ERÚ. Retrieved from http://www.eru.cz/user_data/files/statistika_elektro/rocni_zprava/2012/RZ_elektro_2012_v1.pdf

Energetický regulační úřad / Operátor trhu s elektřinou. (2012). Roční zpráva o dodávkách a spotřebách zemního plynu v plynárenské soustavě ČR: leden - prosinec 2011. Retrieved from http://www.eru.cz/ user_data/files/plyn/40_statistika/vyhodnoceni/Plyn \%202011.pdf

Energetický regulační úřad. (n.d.a). FAQ - Často kladené dotazy v teplárenství. Retrieved from http:// www.eru.cz/dias-read_article.php?articleId=879

Energetický regulační úřad. (n.d.b). Počet změn dodavatele plynu v ČR na odběrné místo. Retrieved from http://eru.cz/user_data/files/plyn/40_statistika/vyhodnoceni/Zmena dodavatele.XLS

Energostat. (2011). Hrozba nedostatku uhlí pro teplárny. Retrieved from http://www.energostat.cz/

Energostat. (n.d.). Teplárenství $\check{C} R$. Retrieved from http://energostat.cz/teplarenstvi-cr.html 
Energy Charter. Retrieved from http://www.encharter.org/

Energy Information Administration. (2010). Germany Energy Profile. Retrieved from http://www.eia.gov/ Eni Česká republika, s. r. o. Retrieved from http://www.agip.cz

ENTSOG - Capacity map - information by cross-border point (version: June 2010). (2010a). Retrieved from http://www.entsog.eu/

ENTSOG - The European Natural Gas Grid Map (January 2010). (2010b). Retrieved from http://www. entsog.eu/

ENTSOG - The European Natural Gas Network Capacity Map - Capacities at cross-border points on the primary market (version: January 2010). (2010c). Retrieved from http://www.entsog.eu/

ENVIROS, s. r. o. (2009). Energy Efficiency Policies and Measures in the Czech Republic in 2007: Monitoring of Energy Efficiency in EU 27, Norway and Croatia (ODYSSEE-MURE). Retrieved from http:// www.odyssee-indicators.org/publications/PDF/czech_nr.pdf

EU a energetika. (n.d.). Legislativa EU k energetice. Retrieved from http://www.energetika-eu.cz/

EU má prý dohodu o energiích. Češi o ní neví. (2007, March 8). Lidové noviny. Retrieved from

EU Emissions Trading Scheme. (2007, January 22). EurActiv.com. Retrieved from http://www.euractiv. $\mathrm{com} / \mathrm{en}$

EUR-Lex - Přistup k právu Evropské unie. Retrieved from http://eur-lex.europa.eu/

European Association for Coal and Lignite. Retrieved from http://www.euracoal.org/

European Atomic Energy Community. Retrieved from http://www.euratom.org/

European Commission, \& Joint Research Centre (n.d.). PVGIS Solar Irradiation Data. Retrieved from http://re.jrc.ec.europa.eu/pvgis/apps/radmonth.php?en=\&europe

EurActive. (2009, January 19). Rusové a Ukrajinci se dohodli, ted' snad už doopravdy. Retrieved from http://www.euractiv.cz/energetika/clanek/rusove-a-ukrajinci-se-dohodli-ted-snad-uz-doopravdy-005512

EurActive. (2009, May 11). Turecko kývlo na Nabucco. Kdo ho zaplatí? Retrieved from http://www.euractiv.cz/energetika/clanek/turecko-kyvlo-na-nabucco-kdo-ho-zaplati-005976

EurActive. (2009, May 29). Na Slovensku vyroste novájaderná elektrárna, postavíji ČEZ. Retrieved from http:// www.euractiv.cz/energetika/clanek/na-slovensku-vyroste-nova-jaderna-elektrarna-postavi-ji-cez-006059

EurActive. (2009, July 16). Výsledky českého předsednictví v energetice. Retrieved from http://www. euractiv.cz/energetika/link-dossier/vysledky-ceskeho-predsednictvi-v-energetice-000054

Eurostat. Retrieved from http://epp.eurostat.ec.europa.eu/portal/page/portal/eurostat/home/

Evropská komise. (1998). Pravidelná zpráva o ČR 1998. Retrieved from http://ec.europa.eu/ceskarepublika/pdf/pravzpravacr1998.pdf

Evropská komise. (2005). Zelená kniha o energetické účinnosti. Retrieved from http://ec.europa.eu/ceskarepublika/pdf/press/ks6_ek_geen_paper.pdf

Evropská komise. (2006a). Národní alokační plán České republiky 2008 až 2012. Retrieved from http:// www.mzp.cz/C1257458002F0DC7/cz/narodni_alokacni_plan/\$FILE/OZK-NAP_2-20081008.pdf 
Evropská komise. (2006b). Akční plán pro energetickou účinnost: využití možností. Retrieved from http:// eur-lex.europa.eu/LexUriServ/LexUriServ.do?uri=COM:2006:0545:FIN:CS:PDF

Evropská komise. (2006c). Zelená kniha Evropská strategie pro udržitelnou, konkurenceschopnou a bezpečnou energii. Retrieved from http://ec.europa.eu/energy/green-paper-energy/doc/2006_03_08_gp_document_cs.pdf

Evropská komise. (2007). Boj proti změně klimatu. Vưdčí úloha EU. Retrieved from http://ec.europa.eu/ publications/booklets/move/70/cs.pdf

Evropská unie. (2010). Priority energetických infrastruktur do roku 2020 a na další období - návrh na integrovanou evropskou energetickou sit'. Retrieved from http://eur-lex.europa.eu/LexUriServ/LexUriServ. do?uri=COM:2010:0677:FIN:CS:PDF

Evropské sitě čeká jen do roku 2015 investice 28 miliard eur. (2010, March 2). Euraktiv. Retrieved from http://www.euractiv.cz/energetika/clanek/evropske-site-ceka-jen-do-roku-2015-investice-28-miliardeur-007160

Evropský parlament. (2008, December 17). Parlament stvrdil klimaticko-energetický balíček. Retrieved from http://www.europarl.europa.eu/sides/getDoc.do?pubRef=-//EP//TEXT+IM-PRESS+20081216IPR44857+0+$\mathrm{DOC}+\mathrm{XML}+\mathrm{V} 0 / / \mathrm{CS}$

Fabián, J. (2010, June). Zisková hlubinná těžba uhlí v Evropě - fikce nebo realita? Prezentace na konferenci Těžba uhlí v ČR: alternativy budoucího vývoje, Praha. Retrieved from http://www.ivd.cz/cs/energeticka_bezpecnost_cr/tezba_uhli_cr_alternativy_budouciho_vyvoje

Faltýnek, V. (2008, December 15). Bursík: Česko pomohlo vyjednat klimaticko-energetický balíček. Rádio Praha-Český rozhlas 7. Retrieved from http://m.radio.cz/cz/rubrika/udalosti/bursik-cesko-pomohlo-vyjednat-klimaticko-energeticky-balicek

Final Report diskusnich setkání: Je zaručený př́sun energií samozřejmostí? týdeníku Ekonom, IVD Institutu pro veřejnou diskusi a Mezinárodního politologického ústavu Masarykovy univerzity, Praha. Retrieved from http://www.ivd.cz/download/Final_Report_IVD_EB.pdf

Fischer by rád, kdyby Miko zůstal. Ministr odmítá. (2009, October 19). Aktualne.cz. Retrieved from http:// aktualne.centrum.cz/domaci/politika/clanek.phtml?id=650546

Fotovoltaika. (n.d.). Nazeleno.cz. Retrieved from http://www.nazeleno.cz/

Fránek, T. (2010, March 11). Ruská nespolehlivost straší, na Moravě roste plynovod. Aktuálně.cz. Retrieved from http://aktualne.centrum.cz/

Fyzikální aspekty zátěží životního prostředí (2008). Studijní text pro kurz Fyzikální aspekty zátěží životního prostředí, Katedra fyziky Přírodovědecké fakulty Ostravské univerzity. Retrieved from http://artemis.osu.cz:8080/artemis/uploaded/212_FAEZP \%20v10 \%20k \%209.12.08.pdf

Gas Infrastructure Europe. Retrieved from http://www.gie.eu/

GAS, s. r. o. Zemní plyn. Informační stránky společnosti. Retrieved from http://www.zemniplyn.cz/

Gavenda, M. (2006). Podzemní zásobníky plynu-důležitý článek v plynárenské soustavě. Retrieved from http://slon.diamo.cz/hpvt/2006/stavby/P11.htm

Gavor, J. (2007). Ceny zemního plynu - co nového v roce 2007. Pro-Energy magazín, 2007(2), pp. 28-30.

Retrieved from http://pro-energy.cz/clanky2/2.pdf 
Gavor, J. (2008). Ceny zemního plynu - co nového v roce 2008. Pro-Energy magazín, 2008(2), pp. 24-27. Retrieved from http://pro-energy.cz/clanky6/3.pdf

Gazprom in questions and answers. Retrieved from http://eng.gazpromquestions.ru/

Gazprom zvažuje zvýšení kapacity plynovodu South Stream. (2005, January 28). Finančnik. Retrieved from http://www.financnik.sk/financie.php?did=54\&messagefr=ZA\&messageid=749166\&messagetitle $=$ Gazprom + Zva $\% 9$ Euje + Zv $\%$ FD \%9Aen \%ED+kapacity + plynovodu+South + Stream\&date $=20090129092239 \&$ lid $=79 \&$ page_messages $=\&$ category $=\&$ which $=\& \mathrm{dt}=\&$ text $=\& \mathrm{kriza}=$

Geotermálni energie. (n.d.). Retrieved from http://www.mzp.cz/cz/geotermalni_energie

Geussová, M. (2010). Na třetí balíček EU máme rok na implementaci. Pro-Energy magazín, 2010(1), pp. 12-13. Retrieved from http://pro-energy.cz/clanky13/1.pdf

Geussová, M., \& Pravec, J. (2008, June 19). Bliží se doba plynová. Ekonom. Retrieved from http://ekonom. ihned.cz/c1-25588020-blizi-se-doba-plynova

Gigantické nádrže na ropu chrání strategické zásoby. (2008, October 9). Enviweb. Retrieved from http:// www.enviweb.cz/

Götz, R. (2005). Russia and the Energy Supply of Europe - The Russian Energy Strategy to 2020. Retrieved from http://www.swp-berlin.org/common/get_document.php?asset_id=2476

Graham, P. (2007, October 18). Poland's PKN Orlen or unit could buy stake in Trieste-Germany pipeline. AFX News Limited, Forbes. Retrieved from http://www.forbes.com/

GSE Storage Map - information by point (version: August 2010). Retrieved from http://www.gie.eu.com/ maps_data/downloads/GSE_STOR_August2010.pdf

Hlinomaz, P. (2009, August 13). Ovlivňuje ČEZ politiky nebo naopak? Hospodářské noviny. Retrieved from http://hn.ihned.cz/c1-38046290-ovlivnuje-cez-politiky-nebo-naopak

Hnutí DUHA. (2010). Státní energetická koncepce: uhlí versus hi-tech. Retrieved from http://www.hnutiduha.cz/publikace/SEK_uhli_versus_hi-tech.pdf

Holub, P., Mikeska, M., \& Kotecký, Vojtěch (2006). Obnovitelné zdroje energie. Brno: Hnutí DUHA. Retrieved from www.hnutiduha.cz/publikace/obnovitelne_zdroje_energie.pdf

Horáček, F. (2009, June 25). V Česku bude první velká paroplynová elektrárna, ČEZ vyjde na 20 miliard. iDnes.cz. http://www.idnes.cz/

Horčík, J. (2009, December 7). Česká republika zvýší podíl biopaliv v benzinu a naftě. Hybrid.cz. Retrieved from http://www.hybrid.cz/

Horčík, J. (2010, March 18). Podíl biopaliv v benzinu a naftě se v ČR zvýší. Hybrid.cz. Retrieved from http://www.hybrid.cz/

Horník, T. (2010). Regulace cen odvětví elektroenergetiky v ČR. Ekonomika a Management, 2010(3). Retrieved from http://www.ekonomikaamanagement.cz/cz/clanek-regulace-cen-odvetvi-elektroenergetiky-v-cr.html

Horník, T., \& Drahovzal, O. (2008). Nová rizika v energetice - velkoobchodní trh s elektřinou. Ekonomika a Management, 2008(3). Retrieved from http://www.ekonomikaamanagement.cz/cz/clanek-nova-rizika-v-energetice-velkoobchodni-trh-s-elektrinou.html 
Hoši z Motoinvestu roztáčeji kola uhelné války. (2012b, March 22). Ekonom. Retrieved from http:// ekonom.ihned.cz/c1-55116420-hosi-z-motoinvestu-roztaceji-kola-uhelne-valky

Höth, H., \& Drábová, D. (2006). Rizika přesahující hranice - Případ Temelín. Retrieved from http://www. csvts.cz/cns/news06/temcase.pdf

Hovet, J. (2008, May 7). Czech Republic negotiating for 2 pct stake in Tal oil pipeline. Thomson Financial News, Forbes. Retrieved from http://www.forbes.com/

Hradilek, L. (2011, June 6). Václav Klaus na korečkovém bagru. Prezident křtil rypadlo Severočeských dolů. Aktuálně.cz. Retrieved from http://aktualne.centrum.cz/

HRAPRAKO Komoditní burza. Retrieved from http://www.hraprako.cz/

Hruban, R. (2007/2011). Energetické suroviny v oblasti moravských Karpat. Retrieved from http:// moravske-karpaty.cz/priroda_soubory/suroviny/energeticke_suroviny.htm

Hrubý, Z. (1999, February 28). Závěrečná zpráva expertního týmu pro nezávislé posouzení projektu dostavby Jaderné elektrárny Temelín. Retrieved from http://new.ecn.cz/doc/old/Enviro/energetika/Texts/ zprava_komise.htm

Hruška, B. (2007, May 15). Blokády a Temelín? Schwarzenberg se zlobí. Aktuálně.cz. Retrieved from http://aktualne.centrum.cz/

Hui, L. (2011, January 6). China aims to expand thermal power capacity by $80 \mathrm{mln} \mathrm{kw}$ in 2011. xinhuanet. com. Retrieved from http://www.xinhuanet.com/english2010/

Charakteristika sítí ES ČR. (n.d). Fakulta elektrotechnická Západočeské univerzity v Plzni. Retrieved from http://stag.zcu.cz/fel/kee/PE-Průmyslová_energetika/CharakteristikaES.pdf/

Ihned. (2009, January 12). Shrnutí: den, kdy skončila plynová krize. Retrieved from http://byznys.ihned. cz/c1-32621600-shrnuti-den-kdy-skoncila-plynova-krize

Index Mundi. Retrieved from http://www.indexmundi.com/

Institut energetických informací. (2011). Bilance hnědého uhlí v letech 2013 - 2020 a územni ekologické limity. Retrieved from http://www.inergin.cz/file/3/studie-inergin---nedostatek-uhli.pdf

Institut pro veřejnou diskuzi. (2010). FINAL REPORT 2010 Energetická bezpečnost ČR. Retrieved from http://www.ivd.cz/download/Final_Report_IVD_EB.pdf

International Atomic Energy Agency. Retrieved from http://www.iaea.org/

International Energy Agency. (n.d.). Selected 2007 Indicators for Czech Republic. Retrieved from http:// www.iea.org/index.asp

International Energy Agency. (2010a). 2007 Energy Balance for Czech Republic. Retrieved from http:// www.iea.org/stats/balancetable.asp?COUNTRY_CODE=CZ

International Energy Agency.(2010b). Monthly natural gas survey - February 2010. Retrieved from http:// www.iea.org/stats/surveys/natgas.pdf

Jaderná elektrárna versus elektrárna uhelná. Retrieved from http://www.vodni-tepelne-elektrarny.cz/jaderna-uhelna-elektrarna.htm 
Jahnátek: Spojit' Schwechat s ropovodom Družba je potrebné. (2009, December 29). ekonomika.sme.sl. Retrieved from http://ekonomika.sme.sk/

Januszek, T. (2010, July 1). OKD zatím na polské straně těžit nebude. Deník.cz. Retrieved from http:// www.denik.cz/

Jihočeské matky. (2007). Otevřený dopis představenstvu a dozorčí radě společnosti ČEZ. Retrieved from http://www.jihoceskematky.cz/

Jihočeské matky. (2011). Společná tisková zpráva: Rozdrtí ekonomická analýza atomové sny? Retrieved from http://www.jihoceskematky.cz/

Jirásek, J., \& Vavro, M. (2008). Nerostné suroviny a jejich využití. Studijní materiál Ministerstva školství, mládeže a tělovýchovy ČR \& Vysoké školy báňské - Technické univerzity Ostrava. Retrieved from http:// geologie.vsb.cz/loziska/suroviny/index.html

Jones, T. (2010, November 27). Czechs up access to ‘emergency’ Western oil on Russia’s warning. CzechPosition.com. Retrieved from http://www.ceskapozice.cz/en

Kabele, K. (2010, August 30). Revize evropské směrnice 2002/91/ES o energetické náročnosti budov. Retrieved from http://www.tzb-info.cz/hodnoceni-energeticke-narocnosti-budov/6739-revize-evropske-smernice-2002-91-es-o-energeticke-narocnosti-budov

Karafiát, J. (2001, December). Teplárenství. Retrieved from http://k315.feld.cvut.cz/download/tep/teplarenstvi.pdf

Karafiát, J. a kol. (2006, October). Sbornik technických řešení zdrojů s kombinovanou výrobou elektřiny a tepla. Retrieved from http://www.mpo-efekt.cz/dokument/15.pdf

Kastl, J. (2008). Zemní plyn - zajištění bezpečnosti a spolehlivosti dodávek. Prosperita, 10(1), p. 25. Retrieved from http://www.prosperita.info/dwn/casopis/2008-01_issue.pdf

Kaufmann, P. (2007). Vývoj teplárenství v České republice. Pro-Energy magazín, 2007(4), pp. 18-21. Retrieved from http://www.pro-energy.cz/clanky4/pe_cislo4.pdf

Kavina, P. (2010, červen). Lze uhlí jako významný a průmyslový zdroj $\check{C} R$ zcela nahradit? Prezentace na konferenci Těžba uhlí v ČR: alternativy budoucího vývoje, Praha. Retrieved from http://www.ivd.cz/ cs/energeticka_bezpecnost_cr/tezba_uhli_cr_alternativy_budouciho_vyvoje

KDU-ČSL. (2002). Programové prohlášení koalice. Retrieved from http://www.kdu.cz/clanek.as$\mathrm{p} ? \mathrm{id}=1853 \#$

KDU-ČSL. (2006). KDU-ČSL Volební program: volby 2006 - klidná síla. Retrieved from http://www.kdu. cz/getattachment/Dokumenty/Volby/2006/Volby-do-PSP-CR/Volebni-program-KDU-CSL-2006---2010/ Volebni_program_KDU-CSL_2006_-_2010_pdf.pdf.aspx

KDU-ČSL. (2009). Volební program pro volby do Evropského parlamentu 2009-2014. Retrieved from http://www.roithova.cz/soubory/Volebni_program_KDU-CSL_do_EP_2009-2014.pdf?fid=1241961694

KDU-ČSL. (2010). KDU-ČSL Volební program 2010-2014 - to lepší v nás. Retrieved from http://www. kdu.cz/Kdu/media/Kdu/Volby/KDU_program.pdf

Klímová, J. (2010, March 19). Českou naftu z nouzových zásob uskladní Němci. iDNES.cz. Retrieved from http://www.idnes.cz/ 
Klímová, J. (2013, March 19). Obchod za miliardy -Tykač prodal důl, který zásobuje české teplárny. iDNES.cz. Retrieved from http://www.idnes.cz/

Kocourek: cenu uhlí určí nejlevnějši u těžařu. (2011, May 13). E15. Retrieved from http://zpravy.e15.cz/ byznys/prumysl-a-energetika/kocourek-cenu-uhli-urci-nejlevnejsi-z-tezaru-600545.

Kocourek: stát by neměl těžbu za limity brzdit. (2011, March 11). Hospodářské noviny. Retrieved from http://hn.ihned.cz/c1-51085480-kocourek-stat-by-nemel-tezbu-za-limity-brzdit

Komise Evropských společenství. (2009, July 16). Návrh Nařízení Evropského parlamentu a rady o opatřeních na zabezpečení dodávek zemního plynu a o zrušení směrnice 2004/67/ES. Retrieved from http://eur-lex.europa.eu/LexUriServ/LexUriServ.do?uri=COM:2009:0363:FIN:CS:PDF

Komise pro životní prostředí Akademie věd ČR. (2010, March 3). Stanovisko Komise pro životní prostředí Akademie věd ČR k problematice tzv. ,územnich ekologických limitů těžby“ "v Severočeské hnědouhelné pánvi (SHP). Retrieved from http://press.avcr.cz/miranda2/export/sitesavcr/data.avcr.cz/press/UserFiles/ file/aktuality_pdf/Komise_pro_zivot_prostredi_AV_CR_limity_uhli_nesouhlas_3_3_10.pdf

Komise vitá prijetí klimaticko-energetického balícku. (2009, April 23). Retrieved from http://europa. $\mathrm{eu} / \mathrm{rapid} /$ pressReleasesAction.do?reference $=\mathrm{IP} / 09 / 628 \&$ format $=$ HTML\&aged $=0 \&$ language $=$ CS\&guiLanguage $=$ en

Konec ,zelené“ Benziny. (2001). Magazín Petrol 2001(3). Retrieved from http://www.petrol.cz/magazin/

Kopecký, J. Št’astný, J. (2011, November 15). Ministrem průmyslu bude Martin Kuba. Nečas ho nechtěl do vedení ODS. Idnes.cz. Retrieved from http://zpravy.idnes.cz/ministrem-prumyslu-bude-martin-kubanecas-ho-nechtel-do-vedeni-ods-10k-/domaci.aspx?c=A111115_150709_domaci_kop

Košt’ál, J. (2010). Elektromobilita - budoucnost již začala. Časopis Elektro, 2010(10), pp. 6-10. Retrieved from http://www.odbornecasopisy.cz/pdfclick.php?id=42017

Kotora, B. (2009, June 1). Energetická budoucnost: virtuální elektrárny a inteligentní sítě. Hospodářské noviny. Retrieved from http://technik.ihned.cz/

Krajíček, L., \& Rothbauer, I. (2004, Eds.). Územní prognóza území dotčeného těžbou hnědého uhlí na Sokolovsku - Návrh. Retrieved from www.medard-lake.eu/file_download/78

Kreusch, J., Neumann, W., Appel, D., \& Diehl, P. (2006). Jaderný palivový cyklus. Nuclear Issues Paper (3). Retrieved from http://www.boell.de/downloads/oekologie/3_Jaderny_palivovy_cyklus_Oekologie.pdf

Krpec, O. (2009). Národní zájmy v moderní demokracii - Česká republika. Retrieved from http://www. kas.de/wf/doc/kas_16253-1522-2-30.pdf?110210162602

KSČM. (2006). Program KSČM do Poslanecké sněmovny PČR 2006. Retrieved from http://www.kscm. cz/viewDocument.asp?document $=4028$

KSČM. (2009). Otevřený volební program KSČM pro volby do Evropského parlamentu 2009. Retrieved from http://www.kscm.cz/volby-a-akce/volby-do-ep-2009/volebni-program

KSČM. (2010). Otevřený volební program KSČM pro volby do PS PČR 2010. Retrieved from http:// www.kscm.cz/index.asp?thema $=4393 \&$ category $=$

KSČM. (2010, April 17). Stanovisko k prolomení limitů těžby uhlí v Ústeckém kraji. Retrieved from $\mathrm{http}: / /$ www.kscm.cz/article.asp?thema=2730\&item=47716\&category= 
Kuba je proti trvalé garanci výkupních cen pro nový Temelín. (2013, February 18). E15.cz. Retrieved from http://zpravy.e15.cz/byznys/prumysl-a-energetika/kuba-je-proti-trvale-garanci-vykupnich-cen-pro-novy-temelin-958157

Kubátová, Z. (2010, February 16). Kauza Ostramo: Spor o miliardy už vynesl slušné zisky. Hospodářské noviny. Retrieved from http://ekonomika.ihned.cz/c1-40574040-spor-o-miliardy-uz-vynesl-slusne-zisky

Kubátová, Z. (2009, October 15). Vladimír Tošovský: Jednou to uhlí bude potřeba vytěžit. Hospodářské noviny. Retrieved from http://hn.ihned.cz/c1-38658610-vladimir-tosovsky-jednou-to-uhli-bude-potreba-vytezit

Kubátová, Z. (2012, February 9). RWE prodává české plynovody. Za dceřinou Net4Gas může dostat až 50 miliard. Hospodářské noviny. Retrieved from http://byznys.ihned.cz/c1-54657010-rwe-prodava-ceskeplynovody-za-dcerinou-net4gas-muze-dostat-az-50-miliard

Kukliš, L. (2007, January 30). Abdusamatov: Za změny podnebí může Slunce, čeká nás ochlazení. Gnosis9.net. Retrieved from http://gnosis9.net/view.php?cisloclanku=2007010011

Kukliš, L. (2008, February 4). Abdusamatov: Slunce ochlazuje Zemi, čeká nás malá doba ledová. Gnosis9.net. Retrieved from http://gnosis9.net/view.php?cisloclanku=2008020001

Kysilka, H. (2007). Plyn, strategické partnerstvi prověrené desetiletími. Pro-Energy magazín, 2007(3), pp. 22-28. Retrieved from http://pro-energy.cz/clanky3/2.pdf

Landscheidt, T. (1998). Solar Activity: A Dominant Factor in Climate Dynamic. Retrieved from http:// www.john-daly.com/solar/solar.htm

Lebedev, K. (2010). Fears that Russia might lose European market ungrounded. Institute for Financial Studies. Retrieved from http://www.ifs.ru/upload/250110-gas_en.pdf

Léko, I. (2011a, July 20). Šéfkou ERÚ je plynová královna Alena Vitásková. Česká pozice. Retrieved from http://www.ceskapozice.cz/domov/politika/sefkou-eru-je-plynova-kralovna-alena-vitaskova

Léko, I. (2011b, November 30). Jak Tošovského vláda selhala. Svědectví o kritickém dni v historii Mostecké uhelné. Českápozice.cz. Retrieved from: http://www.ceskapozice.cz/domov/pravo-bezpecnost/ jak-tosovskeho-vlada-selhala-svedectvi-o-kritickem-dni-v-historii-mostecke-uh

Liberalising the EU energy sector. (2008, May 5). EurActiv. Retrieved from http://www.euractiv.com/ energy/liberalising-eu-energy-sector-linksdossier-188362

Libra, M. (n.d.). 9. Jaderná energie. Studijní text Technické fakulty České zemědělské univerzity v Praze. Retrieved from http://etext.czu.cz/img/skripta/64/tf_4410-1.pdf

Lukáč, P. (2011, November 2). Energetická koncepce státu je mimo realitu, shodují se experti. Hospodářské noviny. Retrieved from http://byznys.ihned.cz/zpravodajstvi-cesko/c1-53471450-energeticka-koncepce-statu-je-mimo-realitu-shoduji-se-experti

LUKOIL Czech Republic, s. r. o. Retrieved from http://www.lukoil.cz/

Macková, K. (2011, May 19). Nečas: Zátěžové testy jaderných elektráren by neměly řešit teroristické útoky. EuroZpravy.cz. Retrieved from http://domaci.eurozpravy.cz/politika/27890-necas-zatezove-testy-jadernych-elektraren-by-nemely-resit-teroristicke-utoky/ 
Máslo, K. (n.d.). Řizení frekvence - bilance činných výkonů v ES. Přednáška k předmětu Ř́zení ES, Vysoká škola báňská - Technická uiverzita Ostrava, Fakulta elektrotechniky a informatiky, Katedra elektroenergetiky. Retrieved from http://fei1.vsb.cz/kat410/studium/studijni_materialy/res/Prednaska_Rizeni_ frekvence3_Maslo.pdf

Masopustová, V., Táborská, M. (2010, February 11). O energetické koncepci by nově mohla rozhodovat sněmovna. Český rozhlas. Retrieved from http://www.rozhlas.cz/zpravy/politika/_zprava/o-energeticke-koncepci-by-nove-mohla-rozhodovat-snemovna--693572

Maštálka, J. (2009, July 21). České předsednictví zklamalo. Haló noviny. Retrieved from http://www. halonoviny.cz/index.php?id=81781

Matocha, P. (2010). Pět plynovodů k energetické bezpečnosti Česka. Retrieved from http://www.euro.cz/ detail.jsp?id=20630

Mayer, B. (2009, June 5). ČEZ nekoupí polský důl Bogdanka. Euro.cz. Retrieved from http://www.euro.

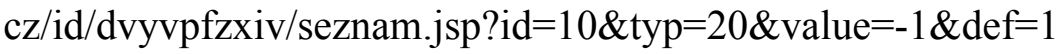

Medek, T. (2010, April 14). Část strategických zásob nafty bude ČR skladovat v Německu. Český rozhlas. Retrieved from http://www.rozhlas.cz/zpravy/portal

Mejstř́k, M., \& Marková, K. (2010). Zajištěni energetické bezpečnosti v oblasti dodávek zemního plynu. Přednáška v rámci cyklu Ekonomická bezpečnost ČR Vysoká škola ekonomická v Praze. Retrieved from http://mochovmistoprozivot.cz/media/Zdroje \%20informaci/Energeticka \%20bezpecnost \%20VSE \%20 $20100408 \% 20$ Plyn.pdf

Memorandum o porozumeni medzi Ministrom hospodárstva Slovenskej republiky a Spolkovým ministrom hospodárstva, rodiny a mládeže Rakůskej republiky o spolupráci v energetickom sektore. (2009, 16. ř́jen). Retrieved from http://www.nrsr.sk/appbin/Tmp/odpoved_14_1298.pdf

MERO $\check{C} R$, a. s. Retrieved from http://www.mero.cz/

MERO ČR, a. s. (2008). Historie MERO ČR. Retrieved from http://www.mero.cz/

MERO ČR, a. s. (2010, May 6). Dohoda z Minsku zvýší bezpečnost dodávek ropy. Retrieved from http:// www.mero.cz/

MfD: Č́st státních nouzových zásob nafty bude skladována u soukromé firmy v Německu. (2010, March 19). Patria Online. Retrieved from http://www.patria.cz/Zpravodajstvi/1588183/mfd-cast-statnich-nouzovych-zasob-nafty-bude-skladovana-u-soukrome-firmy-v-nemecku.html).

Ministerstvo dopravy České republiky. (2005). Dopravní politika České republiky pro léta 2005 - 2013. Retrieved from http://www.mdcr.cz/NR/rdonlyres/652F57DA-5359-4AC6-AC42-95388FED4032/0/ MDCR_DPCR20052013_UZweb.pdf

Ministerstvo dopravy České republiky. (2008). Ročenka dopravy 2007. Retrieved from https://www.sydos. cz/cs/rocenka-2007/index.html

Ministerstvo průmyslu a obchodu. (1999, December 13). Surovinová politika v oblasti nerostných surovin a jejich zdrojů. Retrieved from http://download.mpo.cz/get/26649/44033/533470/priloha002.doc

Ministerstvo průmyslu a obchodu. (2004). Státní energetická koncepce České republiky. Retrieved from http://www.mpo.cz/dokument5903.html 
Ministerstvo průmyslu a obchodu. (2008). Národní zpráva České republiky o elektroenergetice a plynárenství za rok 2007. Retrieved from http://download.mpo.cz/get/35309/39712/465451/priloha001.doc

Ministerstvo průmyslu a obchodu. (2009a, October). Aktualizace Státní energetické koncepce České republiky - ř́ljen 2009. Retrieved from www.mpo.cz/kalendar/download/71707/priloha002.pdf

Ministerstvo průmyslu a obchodu. (2009b). Národní zpráva České republiky o elektroenergetice a plynárenství za rok 2008. Retrieved from http://www.energy-regulators.eu/portal/page/portal/EER_HOME/EER_PUBLICATIONS/NATIONAL_REPORTS/National \%20Reporting \%202009/NR_nl/E09_NR_CzechRep-LL.pdf

Ministerstvo průmyslu a obchodu. (2009c). Ropa a ropné produkty za 1. až 3. čtvrtletí 2009. Retrieved from http://download.mpo.cz/get/40317/44861/547185/priloha001.pdf

Ministerstvo průmyslu a obchodu. (2009d). Ropa a ropné produkty za rok 2008. Retrieved from http:// download.mpo.cz/get/38128/42518/509862/priloha001.pdf

Ministerstvo průmyslu a obchodu. (2009e). Surovinová politika v oblasti nerostných surovin a jejich zdrojio. Retrieved from http://download.mpo.cz/get/26649/44033/533470/priloha002.doc

Ministerstvo průmyslu a obchodu. (2010a). Aktualizace Státní energetické koncepce České republiky únor 2010. Retrieved from http://download.mpo.cz/get/26650/45632/552383/priloha001.pdf

Ministerstvo průmyslu a obchodu. (2010b). Působnost ministerstva. Retrieved from http://www.mpo.cz/ dokument1926.html

Ministerstvo průmyslu a obchodu. (2010c). Kombinovaná výroba elektřiny a tepla v roce 2008 - Výsledky statistického zjištování. Retrieved from http://download.mpo.cz/get/41312/46101/555531/priloha001.pdf

Ministerstvo průmyslu a obchodu. (2010d). Národni akční plán České republiky pro energii z obnovitelných zdrojü. Retrieved from http://download.mpo.cz/get/42577/47632/568798/priloha001.pdf

Ministerstvo průmyslu a obchodu. (2010e). Národní zpráva České republikyo elektroenergetice a plynárenství za rok 2009. Retrieved from http://download.mpo.cz/get/35250/46994/562257/priloha001.doc

Ministerstvo průmyslu a obchodu. (2010f). Produkce tuhých fosilnich paliv za rok 2009. Retrieved from http://download.mpo.cz/get/40817/45537/551686/priloha001.pdf

Ministerstvo průmyslu a obchodu ČR. (2010g). Zpráva o bezpečnosti dodávek zemního plynu za rok 2009. Retrieved from http://download.mpo.cz/get/42075/46995/562260/priloha001.doc

Ministerstvo průmyslu a obchodu ČR. (2010h). Státní energetická koncepce $\check{C} R$. Retrieved from http:// www.mpo.cz/dokument5903.html

Ministerstvo průmyslu a obchodu. (2011a). Ropa a ropné produkty za rok 2010. Retrieved from http:// download.mpo.cz/get/43767/49122/576190/priloha001.pdf

Ministerstvo průmyslu a obchodu. (2011b, March 24). Závěry pracovní komise pro teplárenství. Retrieved from http://www.mpo.cz/dokument85493.html

Ministerstvo životního prostředí / Česká geologická služba - Geofond. (2000). Surovinové zdroje České republiky - Geofond České republiky - červen 2000. Retrieved from http://www.geofond.cz/dokumenty/ nersur_rocenky/rocenkanerudy99/start.htm

Ministerstvo životního prostředí / Česká geologická služba - Geofond. (2001). Surovinové zdroje České republiky - Geofond České republiky - červen 2001. Retrieved from http://www.geofond.cz/dokumenty/ nersur_rocenky/rocenkanerudy00/start.htm 
Ministerstvo životního prostředí / Česká geologická služba - Geofond. (2012). Surovinové zdroje České republiky - nerostné suroviny (Statistické údaje do roku 2011). Praha: Česká geologická služba Geofond. Retrieved from http://www.geology.cz/extranet/publikace/online/surovinove-zdroje/SUROVINOVE-ZDROJE-CESKE-REPUBLIKY-2012.pdf

Ministr Kocourek rezignoval, premiér jeho demisi přijal. (2011, November 9). Hospodářské noviny. Retrieved from http://zpravy.ihned.cz/c1-53586810-ministr-kocourek-rezignoval-premier-jeho-demisi-prijal

MND a Gazprom chtějí v Česku stavět zásobník na plyn. (2008, December 22). Hospodářské noviny. Retrieved from http://www.irucz.ru/cz/zpravy/1-/102000000000-ceska-republika/000-/102000001000jihomoravsky-kraj/302-energetika/15677-mnd-a-gazprom-chteji-v-cesku-stavet-zasobnik-na-plyn/

Morávek, D. (2009, January 19). Fotoreportáž: Na návštěvě podzemního zásobníku plynu. Podnikatel.cz. Retrieved from http://www.podnikatel.cz/clanky/na-navsteve-podzemniho-plynoveho-zasobniku/

Motejlek, M. (2013, March 18). Klíčové parametry smlouvy o dodávkách uhlí mezi ČEZ a Vršanskou uhelnou/Czech Coalem (upřesnění). Motejlek.com. Retrieved from http://www.motejlek.com/

Motlík, J. a kol. (2003). Obnovitelné zdroje energie a možnosti jejich uplatnění v České republice - Studie analyzujicí současný stav, předpoklady rozvoje do r. 2010 a výhled vzdálenějšího horizontu. Retrieved from http://www.cez.cz/edee/content/file/o-spolecnosti/oze-cr-all-17-01-obalka-in.pdf

MPO: (2004). SEK 2004 - Státní energetická koncepce ČR. Retrieved from http:/www.europeangreencities.com/pdf/activities/ConfJun2005/Czech/2. \%20ST \%C3 \%81TN \%C3 \%8D \%20ENERGETICK \%C3 \%81 \%20KONCEPCE.pdf

MPO: (2009). SEK 2009 - Státní energetická koncepce ČR. Retrieved from http://download.mpo.cz/ get/26650/46323/556503/priloha003.doc

MPO: (2010). SEK 2010 - Státní energetická koncepce ČR. Retrieved from http://download.mpo.cz/ get/26650/46323/556505/priloha001.pdf

Mrazivé počasí severočeské elektrárny nezaskočilo. (2010, January 27). regionycr.cz. Retrieved from http://www.regionycr.cz/view.php?hlasovani=3\&cisloclanku=2010010871\&rstema=\&rsstat=\&rskra$\mathrm{j}=\&$ rsregion $=$

Murtinger, K. (2008, July 17). Solární energie - kolik kWh lze získat? Výhody a nevýhody. Nazeleno.cz Retrieved from http://www.nazeleno.cz/

$\mathrm{Na}$ Českomoravské komoditní burze Kladno se prodalo tříděné hnědé uhlí v objemu 8.850 tun. (2009, May 28). All for Power. Retrieved from http://www.allforpower.cz/clanek/na-ceskomoravske-komoditniburze-kladno-se-prodalo-tridene-hnede-uhli-v-objemu-8-850-tun/

Na vytýčení novej trasy ropovodu Bratislava-Schwechat sa stále pracuje. (2008, July 26). ekonomika.sme. $s l$. Retrieved from http://ekonomika.sme.sk/

Nachtmannová, I. (2005, March 21). Geotermální energie v ČR - Zapomenuté teplo z hlubin. Ekolist.cz. Retrieved from http://ekolist.cz/

Národní alokační plán České republiky 2008 až 2012. (2006, November 30). Retrieved from http://ec.europa.eu/environment/climat/pdf/nap_czech_final.pdf

Národní alokační plán České republiky na roky 2005 až 2007. (2005, August) Retrieved from http://portal. gov.cz/wps/dokumenty/NAP \%20final \%20varianta \%20III.pdf 
Nařizeni Evropského parlamentu a rady (ES) č. 715/2009 ze dne 13. července 2009 o podmínkách př́stupu k plynárenským přepravním soustavám a o zrušení nařizení č. 1775/2005 (ze dne 28. zář́i 2009). Retrieved from http://www.eru.cz/user_data/files/legislativa/legislativa_EU/narizeni/715_2009.pdf

Návrh směrnice Radyo bezpečném nakládánís vyhořelým palivem a s radioaktivním odpadem. (2010, November 3). Retrieved from http://eur-lex.europa.eu/LexUriServ/LexUriServ.do?uri=COM:2010:0618:FIN:CS:PDF

Nečas podpořil návrh Kocourka o těžebních limitech. (2011, March 29). Aktuálně.cz. Retrieved from http://aktualne.centrum.cz/

Největší solární elektrárny v ČR. (2010, October 10). Usporim.cz. Retrieved from http://www.usporim.cz/

Němeček, J. (2010). KBC: Ropný sektor v CEE pod tlakem marží a makra. Unipetrol je př́liš drahý, ale začne vyplácet dividendu, analýza ČSOB, 4. 11. 2010, on-line text (http://www.csob.cz/cz/SME/Trhy/ Investicni-okenko/Stranky/hzdetail.aspx?Info=35535).

Němeček, J. (2013, April 8). Šéf ČEZ Beneš: Smlouva s Czech Coal je nejvyšší měrou nedůvěry, jakou jsem v branži zažil. Patria.cz. Retrieved from http://www.patria.cz/

NET4GAS, s. r. o. (2009). Sazebník tarifních služeb č. 3/2009. Retrieved from http://www.net4gas.cz/cs/ media/tarify-ceny/TranzitPriceList_CJ_od11.pdf

NET4GAS, s. r. o. (2010a). Historické měsíčni využití kapacit a průměrné roční prütoky pro vstupní a výstupni body. Retrieved from http://www.net4gas.cz/cs/media/provozni-data/Historicke \%20vyuziti \%20kapacit \%20toky.pdf

NET4GAS, s. r. o. (2010b). Velký zájem v Rakousku - Česká přepravni kapacita. Retrieved from http:// www.net4gas.cz/cs/media/tiskove-zpravy/TZ_LBL_N4G_OMV_CZ_final.doc

Neuerer, D. (2011, April 16). „Deutschland muss Energie-Trendsetter werden“. Handelsblatt. Retrieved from http://www.handelsblatt.com/politik/deutschland/deutschland-muss-energie-trendsetter-werden/4067412.html

Next Finance. (2007). Trh s elektrickou energii v Evropě. Retrieved from http://www.pxe.cz/pxe_downloads/Info/pxe_analyza.pdf

Nezhyba, J., \& Kotecký, V. (2006, May). Návrhy na změnu územních ekologických limitů těžby uhlí: analýza právních argumentů a implikací. Retrieved from www.hnutiduha.cz/publikace/UEL_pravni_analyza.pdf

A New Incandescent Light. (1882, April 30). The New York Times. Retrieved from http://query.nytimes. $\mathrm{com} / \mathrm{mem} /$ archive-free/pdf?res=9401E6D9113EE433A25753C3A9629C94639FD7CF

Novák, J.(n.d.).Výhřevnosti paliv. Retrieved fromhttp://vytapeni.tzb-info.cz/tabulky-a-vypocty/11-vyhrevnosti-paliv

Nowak, O., \& Hnilica, J. (2010). Rafinérský průmysl v České republice a energetická bezpečnost v oblasti dodávek ropy. Ekonomika a Management, 2010 (3). Retrieved from http://www.ekonomikaamanagement.cz/cz/

O prodeji tř́́děného uhlí z Litvínovské uhelné rozhodnuto. (2009, January 16). Českomoravská komoditní burza Kladno. Retrieved from http:/www.cmkbk.cz/cmkbk/portal/media-type/html/user/anon/ page $/$ default.psml/js_pane/statistiky?ksid $=68 \&$ docs.stk_npage $=1 \& \mathrm{ksidparr}=3 \% 2 \mathrm{C} 68 \&$ docs.stk_pageSize $=50 \&$ docs. .stk_page $=0 \&$ paging $=50 \&$ docid $=4836$

OAO Gazprom. Retrieved from http://gazprom.ru/ 
Obnovitelné zdroje nás nespasí a jádru se nevyhneme. (2008, April 1). Hospodářrské noviny. Retrieved from http://hn.ihned.cz/c1-23710760-obnovitelne-zdroje-nas-nespasi-a-jadru-se-nevyhneme

ODS. (2002). Volební desatero - Volební program pro volby do Poslanecké sněmovny 2002. Retrieved from http://www.ods.cz/docs/programy/program_2002.pdf

ODS. (2004). Volební program ODS pro volby do Evropského parlamentu. Retrieved from http://www. ods.cz/docs/programy/program_2004e.pdf

ODS. (2006). Podrobný volební program ODS pro volby 2006 - Společně pro lepší život. Retrieved from https://www.ods.cz/volby/weby/2006/download/docs/volebni_program_ODS.pdf

ODS. (2009a). České předsednictví Evropské unii končí úspěšně. Retrieved from http://virtually.cz/archiv.php?art=18845

ODS. (2009b). Volební program ODS pro volby do Evropského parlamentu 2009. Retrieved from http:// www.ods.cz/docs/programy/program_2009ep.pdf

ODS. (2010). Podrobný volební program ODS pro volby 2010 - Řešení, která pomáhají. Retrieved from http://www.ods.cz/volby2010/dokumenty/182/volebni-program-velky.pdf

Oil transit company Mero extends contract with TAL. (2010, November 24). Prague Daily Monitor. Retrieved from http://praguemonitor.com/

$O K D$, a. s. Retrieved from http://www.okd.cz/

OKD. (n.d.a.) OKD po roce 1990. Retrieved from http://www.okd.cz/cz/o-nas/strucna-historie-okd/okdpo-roce-1990/

OKD. (n.d.b). Historie těžby uhlí. Retrieved from http://www.okd.cz/cz/tezime-uhli/historie-tezby-uhli/?PHPSESSID=27dd99b2f6edb9e162c53c8f05fb4c75

OKD, a. s. (2010). Výroční zpráva 2009. Retrieved from http://www.okd.cz/dokums_presskit/okd_vz_cz_ ok_3687.pdf

Olinger, D. (1996, July 29). Cool to the Warnings of Global Warming's Dangers. St. Petersburg Times. Retrieved from http://mailman.lbo-talk.org/2001/2001-April/006382.html

OMV Česká republika, s. r. o. Retrieved from http://www.omv.cz/

OMV Česká republika, s. r. o. (2009). Výroční zpráva 2008. Retrieved from http://www.omv.cz/portal/01/ $\mathrm{cz} /$ private

OMV prosazuje rychlé vybudování ropovodu Bratislava - Schwechat. (2009, October 19). Periskop. Retrieved from http://www.periskop.cz/cz/clanky/omv-prosazuje-rychle-vybudovani-ropovodu-bratislava-schwechat

Otázky Václava Moravce. (2011, May 15). ČT24. Retrieved from http://www.ceskatelevize.cz/ct24/

Otázky Václava Moravce. (2009, November 8). ČT24. Retrieved from http://www.ceskatelevize.cz/ct24/

OTE, a. s. Retrieved from http://www.ote-cr.cz/

OTE, a. s. (2010a). Technická zpráva 2009. Retrieved from http://www.ote-cr.cz/

OTE, a. s. (2010c). Technická zpráva 2010. Retrieved from http://www.ote-cr.cz/ 
OTE, a. s. (2010b). Výroční zpráva 2009. Retrieved from http://www.ote-cr.cz/

OTE, a. s. (2011). Zpráva o očekávané rovnováze mezi nabídkou a poptávkou elektřiny a plynu. http:// www.ote-cr.cz/statistika/files-dlouhodobe-bilance/Zprava_o_ocekavane_rovnovaze_mezi_nabidkou_a_ poptavkou_elektriny_a_plynu.pdf).

OTE, a. s. (2013). Technická zpráva 2011. Retrieved from http://www.ote-cr.cz/o-spolecnosti/soubory-vyrocni-zprava-ote/vyrocni-zprava-2011.pdf

Paramo, a. s. Retrieved from http://www.paramo.cz/

Paramo, a. s. (2010). Výroční zpráva 2009. Retrieved from http://www.paramo.cz/

Paramo, a. s. (2011). Výroční zpráva 2010. Retrieved from http://www.paramo.cz/

Parlament stvrdil klimaticko-energetický baliček. (2008, December 17). Retrieved from http://www. europarl.europa.eu/sides/getDoc.do?pubRef=-//EP//TEXT+IM-PRESS+20081216IPR44857+0+$\mathrm{DOC}+\mathrm{XML}+\mathrm{V} 0 / / \mathrm{CS}$

Pavlovič, R. (2008, June 30). Bursík zpochybnil práci Pačesovy energetické komise. Český rozhlas. Retrieved from http://www.rozhlas.cz/zpravy/domaci/_zprava/470530

Peterková, P. (2007, Leden). Loni vyrobená elektřina by stačila 5,5 roku pro jižní Čechy. Temelínky, 2007(1), s. 5. Retrieved from http://www.cez.cz/edee/content/file/energie-a-zivotni-prostredi/temelinky-2007-01.pdf

Petr, M. (2011, April 7). Orel na zkoušku. Benzina přemalovala první pumpy na Orlen a Star. Hospodářské noviny. Retrieved from http://ihned.cz/

Petržílek, P. (2009, February 3). Říman se svým návrhem energetické koncepce ujel do minulého století. Petrzilek.blog.iDNES.cz. Retrieved from http://petrzilek.blog.idnes.cz/c/68498/Riman-se-svym-navrhemenergeticke-koncepce-ujel-do-minuleho-stoleti.html

Petržilka, O. (2009a). Proč „,plynová krize“ nenarušila v České republice dodávky plynu? Nebyla to náhoda! Technický týdeník, 2009(8). Retrieved from http://www.techtydenik.cz/index.php

Petrŕíček, M. (2009, March 5). Thomas Kleefuss: Nová plynová krize? Může být horší než v lednu. Hospodářské noviny. Retrieved from http://hn.ihned.cz/c1-35256670-nova-plynova-krize-muze-byt-horsi-nez-v-lednu

Plán na dalši sniženi emisí průmyslníky vyděsil. Je absurdní a naivní, tvrdí. (2010, July 19). Hospodářské noviny. Retrieved from http://ekonomika.ihned.cz/c1-45009220-plan-na-vyssi-snizeni-emisi-vydesilprumyslniky

Pluskal, O. (n.d.). Poválečná historie jáchymovského uranu. Retrieved from http://www.hornictvi.info/ histhor/lokality/jachym/JACHYM2.htm

Pokorný, M. (2011, November 25). Kauza Mostecká uhelná: Stát tak dlouho váhal, až může být promlčená. Hospodářské noviny. Retrieved from http://byznys.ihned.cz/c1-53808650-kauza-mostecka-uhelnastat-tak-dlouho-vahal-az-muze-byt-promlcena

Polanecký, K., \& Sedlák, M. (2010). Př́liš drahý atom - Potíže účastníků temelínského tendru. Retrieved from http://hnutiduha.cz/uploads/media/drahy_atom_www_01.pdf

Polanecký, K., Rovenský, J., Sequens, E., Sedlák, M. \& Kotecký, V. (2009). Čisté teplo. Brno: Hnutí DUHA se sdružením Calla, Greenpeace ČR a Centrem pro dopravu a energetiku. Retrieved from www. hnutiduha.cz/publikace/ciste_teplo.pdf 
Poncarová, J. (2008, November 24). Větrná energie a její využití v České republice. Nazeleno.cz. Retrieved from http://www.nazeleno.cz/

Posudek Komise k žádosti České republiky o přijetí do Evropské unie. (1997). Retrieved from http:// ec.europa.eu/ceskarepublika/pdf/posudek97.pdf

Power Exchange Central Europe, a. s. Retrieved from http://www.pxe.cz/

Power Exchange Central Europe, a. s. (2010). Burzovní řád - pravidla účastnictví. Retrieved from http:// www.pxe.cz/pxe_downloads/Rules_Regulation/Cz/PXE_pravidla_ucastnictvi.pdf

Power Exchange Central Europe, a. s. (2011a). Burzovní pravidla - pravidla obchodování. Retrieved from http://www.pxe.cz/pxe_downloads/Rules_Regulation/Cz/PXE_pravidla_obchodovani.pdf

Power Exchange Central Europe, a. s. (2011b). Účastníci obchodování. Retrieved from http://www.pxe.cz/ Pracovní program českého předsednictví - Evropa bez bariér. (2009). Euroskop. Retrieved from http:// www.euroskop.cz/gallery/38/11622-pracovni_program_ceskeho_predsednictvi_evropa_bez_barier.pdf

Pravec, J. (2012, February 1). EKONOM: Uhlí bude o polovinu dražší kvůli nové dani z dílny ministra Kalouska. Hospodářské noviny. cz. Retrieved from http://byznys.ihned.cz/

Princip tepelné elektrárny. Retrieved from http://www.vodni-tepelne-elektrarny.cz/princip-tepelne-elektrarny.htm

Premiéři V4 chtěji být solidární v řšeni klimatického baličku EU. (2008, November 5). Rozhlas.cz. Retrieved from http://www.radio.cz/cz/rubrika/zpravy/zpravy-2008-11-05\#11

Programové prohlášení vlády. (2010, August 4). Retrieved from http://www.vlada.cz/assets/media-centrum/dulezite-dokumenty/Programove_prohlaseni_vlady.pdf

Protokoll der Verhandlungen zwischen den Regierungen der Tschechischen Republik und der Republik Österreich, geführt von Ministerpräsident Zeman und Bundeskanzler Schüssel im Beisein von EU-Kommissar Verheugen. (2000, December 12). Retrieved from http://www.umweltbundesamt.at/fileadmin/site/ umweltthemen/kernenergie/temelin/Melk/melk_prot_de.pdf

Prugh, T., \& Assadourian, E. (2003). What Is Sustainability, Anyway? Retrieved from http://www. worldwatch.org/system/files/EP165A.pdf

První soukromý ropovod v Čechách. (2003). Retrieved from http://www.petrol.cz/

Přehled cen uhlí a koksu. (2011, March). TZBinfo. Retrieved from http://www.tzb-info.cz/prehled-cenuhli-a-koksu

Rafaelová, L. (2009, November 13). Stát chce dostavbu Temelína ovlivnit speciálním zákonem. Český rozhlas Rádio Česko. Retrieved from http://www.rozhlas.cz/portal/portal

Rada EU. (2008). Společný program Francie, České republiky a Švédska. Retrieved from http://www.eu2009. cz/assets/czech-presidency/pesidency-trio/spolecny-program-francie--ceske-republiky-a-svedska.PDF

Rejstř́k obchodováni s povolenkami OTE, a. s. Retrieved from https://www.povolenky.cz/

Report of the Conference of the Parties on its Third Session, Held at Kyoto, from 1 to 11 December 1997, Addendum, Part Two: Action Taken by the Conference of the Parties at its Third Session. Retrieved from http://www.unfccc.de/resource/docs/cop3/07a01.pdf 
A Review of the Henry Goebel Defense of 1893. (n.d.). Retrieved from http://home.frognet.net/ ejcov/ hgoebel.html

RoBiN OIL, s. r. o. Retrieved from http://www.robinoil.cz/

Ropovod Bratislava - Schwechat by mali začat' stavat' 2012. (2009, October 16). O peniazoch. Retrieved from http://openiazoch.zoznam.sk/info/zpravy/zprava.asp?NewsID=84937

Rusko hrozí Evropě, že přeruší dodávky ropy, dohoda se ale blíží. (2009, December 28). ČT24. Retrieved from http://www.ct24.cz/

Růžička, V. (2009, December 17). (Ne)jaderné elektrárny v elektrizační síti a jejich provoz. Přednáška na FEL ZČU Plzeň. Retrieved from http://vyuka.fel.zcu.cz/kee/JE-nuclear/JADRne_ELEKTRRNY-ruzicka.pdf

RWE Transgas Net, s. r. o. (2009a). Pružnější preshraniční přeprava plynu v Evropě. Retrieved from http://www.net4gas.cz/

RWE Transgas Net, s. r. o. (2009b). RWE Transgas Net a GAZ System plánuji propojení plynovodů. Retrieved from http://www.net4gas.cz/

RWE. (2011, January 20). EČS a ČEPS podepsaly smlouvu o budoucím připojení plánované elektrárny k prenosové soustavě. Dostupné http://www.rwe.cz/

Ryvolová, I. (2006). Ekonomické souvislosti využivání větrné energie v ČR. Dílčí případová studia projektu GAČR 402/06/1784 „Negativní důsledky regulace sít’ových odvětví a vliv změny regulačního paradigmatu“. Retrieved from http://vse.iskola.cz/gacr.pdf

Říman: Odmítáním výsledků Pačesovy komise zelení rozbíjejí koalici. (2008, July 6). Novinky.cz. Retrieved from http://www.novinky.cz/domaci/144267-riman-odmitanim-vysledku-pacesovy-komise-zeleni-rozbijeji-koalici.html

Sedláčková, V., \& Adámková, A. (2009, August 20). ČEZ má spor s Ústeckým krajem kvůli nové paroplynové elektrárně v Počeradech. Český rozhlas. Retrieved from http://www.rozhlas.cz/zpravy/portal

Sedlák, M., Sequens, E., \& Humlíčková, P. (2010). Novela zákona o obnovitelných zdrojích energie (tisk 968). Retrieved from http://hnutiduha.cz/publikace/solarni_elektrina_zakon.pdf

Severočeské doly, a. s. (2010). Výroční zpráva 2009. Retrieved from http://www.sdas.cz/showdoc.do?docid=523

Shell Czech Republic, a. s. Retrieved from http://www.shell.cz/

Shell Czech Republic, a. s.(n.d.). Biopaliva. Retrieved from http://www.shell.cz/

Skupina Czech Coal. Retrieved from http://www.czechcoal.cz/

Skupina Czech Coal. (2010). Roční zpráva skupiny Czech Coal: Hospodaření a udržitelný rozvoj v roce 2009. Retrieved from http://www.czechcoal.cz/cs/ur/zprava/ur2009cz.pdf

Skupina Energy 21. Retrieved from http://www.energy21.cz/

Slivka, V. a kol. (2011, February 11). Studie stavu teplárenství. Retrieved from http://download.mpo.cz/ get/43593/48917/575386/priloha002.pdf

Směrnice Rady 2004/74/ES ze dne 29. dubna 2004, kterou se mění směrnice 2003/96/ES, pokud jde o možnost některých členských států uplatňovat u energetických produktů a elektřiny dočasné osvobození od daně nebo sniženou úroveň zdanění. Retrieved from http://eur-lex.europa.eu/LexUriServ/LexUriServ. do?uri=CELEX:32004L0074:CS:HTML 
Smrček, O. (2007). Úloha ERÚ na liberalizovaném trhu s plynem. Plyn, 2007(6). Retrieved from http:// www.energetik.cz/hlavni3.html?ml=/clanky/pl_2007_06.html

Sokanský, K. a kol. (2007). Dominantní vlivy ovlivňující spotřebu elektrické energie osvětlovacích soustav. Retrieved from http://www.mpo-efekt.cz/upload/7799f3fd595eeeelfa66875530f33e8a/Dominantn__vlivy_ovliv_uj_c_ssot_ebu_elektrick_energie_osv_tlovac_ch_soustav.pdf

Sokolovská uhelná. Retrieved from http://www.suas.cz/

Sokolovská uhelná, právní nástupce, a. s. (2010). Zpráva o hospodaření za rok 2009. Retrieved from http://www.suas.cz/uploads/13935888694c0fe11c33e41_SU_Zprava_o_hospodareni_za_rok_2009.pdf

Sokolovská uhelná. (n.d.). Elektrárna Vřesová bude pojistkou proti blackoutu. Retrieved from http://www.suas.cz/

Southern Corridor Summit Declaration. (2009, August 5). Retrieved from http://www.eu2009. $\mathrm{cz} / \mathrm{en} /$ news-and-documents/press-releases/declaration---prague-summit--southern-corridor-may-8--2009-21533/

Spory podnikatele Andreje Babiše s PKN Orlen. (2009, July 1). Retrieved from http://hn.ihned.cz/c137646280-spory-podnikatele-andreje-babise-s-pkn-orlen

Správa státních hmotných rezerv $\check{C} R$. Retrieved from http://www.sshr.cz/

Správa státních hmotných rezerv. (2009). Analýza možného zapojení podnikatelské sféry do skladování nouzových zásob ropy a ropných produktů s cílem realizovat požadované navýšení nouzových zásob ropy a ropných produktů na úroveň pokrytí 120 dnů. Retrieved from http://download.mpo.cz/ get/38815/43188/516133/priloha005.doc

Správa úložišt’ radioaktivnich odpadů. Retrieved from http://www.rawra.cz/

Stálá mise České republiky ve Vídni. (2010). MAAE - Mezinárodní agentura pro atomovou energii. Retrieved from http://www.mzv.cz/mission.vienna/cz/index.html

Stanovisko prezidenta, jímž vrátil Poslanecké sněmovně zákon o podporovaných zdrojích energie a o změně některých zákoni̊. Retrieved from http://www.platforma-oze.cz/media/188.pdf

Stát se musí do sporu vložit. (2012c, March 22). Ekonom. Retrieved from http://ekonom.ihned.cz/c1-55121640

Státní báňská správa České republiky. Retrieved from http://www.cbusbs.cz/

Státní energetická inspekce - ČR SEI. (n.d.). Retrieved from http://www.mojeenergie.cz/cz/teplarenstvi-uloha-statu\#SEI

Státní energetická koncepce České republiky (schválená usnesením vlády České republiky č. 211 ze dne 10. března 2004). Dostupné http://download.mpo.cz/get/26650/45632/552381/priloha003.doc

Státní úřad pro jadernou bezpečnost. Retrieved from http://www.sujb.cz

Státní úřad pro jadernou bezpečnost. (n.d.a). ČR přistoupila $k$ trojstranným zárukovým dohodám. Retrieved from http://www.sujb.cz/

Státní úřad pro jadernou bezpečnost. (n.d.b). Hodnotici konference ve Vidni potvrdila vysokou úroveň jaderné bezpečnosti v ČR. Retrieved from http://www.sujb.cz/

Státní úr̆ad pro jadernou bezpečnost. (2011). Výroční zpráva SÚJB 2010. Retrieved from http://www.sujb.cz

Státní ústav radiační ochrany, v. v. i. Retrieved from http://www.suro.cz/ 
Statoil Allmennaksjeselskap. Retrieved from http://www.statoil.com/

Statoil. (2007). Kårstø processing plant. Retrieved from http://www.statoil.com/en/Pages/default.aspx

Stejskal, J. (2009, January 13). Klimaticko-energetický balíček EU: Co vlastně obsahuje? A jak o něm hlasovali Češi? Ekolist.cz. Retrieved from http://ekolist.cz/

Stopp, J., Völtz, J., \& Lother, W. (2005, December). Single-source responsibility: KROHNE Flowmetering stations for custody transfer. Oil Gas European Magazine, International Edition of Erdöl Erdgas Kohle, 9,(12), pp. 2-4. Retrieved from http://www.krohne.com/fileadmin/media-lounge/PDF-Download/ Oil_and_Gas/Reprint_TAL_e.pdf

Strana zelených. (2006). Volební program Strany zelených „Kvalita života“ pro volby do Poslanecké sněmovny 2006. Retrieved from http://strana.zeleni.cz/247/86/file/

Strana zelených. (2009). Program Strany zelených pro volby do Evropského parlamentu. Retrieved from http://euvolby.zeleni.cz/data/Program_EP2009.pdf

Strana zelených. (2010). Program Strany zelených pro volby do Poslanecké sněmovny 2010. Retrieved from http://www.zeleni.cz/underwood/download/files/sz-volebni-program-2010.pdf

Strašíková, L. (2009, January 9). Norský plyn má Česko od roku 1997. ČT24.Retrieved from http://www. ct24.cz/

Sušanka, F. (2010, 2. srpen). Třetí ropovod do ČR by mohl vést z Rakouska, nebo Německa. Mediafax. Retrieved from http://zpravy.kurzy.cz/237137-e15-cesko-zvazuje-treti-ropovod/

Sutlovičová, K., \& Kotecký, V. (2006). Národní alokační plán 2008-2012: Připomínky ekologických organizaci k návrhu (MŽP a MPO, 30. ř́ijna 2006). Retrieved from http://www.hnutiduha.cz/publikace/ NAP_2008-12_pripominky.pdf

Sviták, M. (2010). Jaderná elektrárna Temelín si prípomíná 10 let provozu. Informační podklad pro novináře. Retrieved from http://www.csvts.cz/cns/news10/ete10.pdf

Swinoujscie LNG Gas Terminal, Baltic Coast, Poland. (n.d.). Hydrocarbons-technology.com. Retrieved from http://www.hydrocarbons-technology.com/

Šebor, G. (2007, November 3). Rafinérie a ropovody ve střední Evropě. Ekonom. Retrieved from http:// www.enviweb.czl

Šedivý, J. (2003, October 30). Nenažrané spotřebiče aneb kolik nás stojí. Penize.cz. Retrieved from http:// www.penize.cz/

Školiace a konzultačné stredisko Piešt’any. (2007). Něco málo o ropě a zemním plynu. Retrieved from http://www.netesnosti.informacie.sk/files/tech_info_02.pdf

Šobr, M. (2004). Energetika. In Krajiček, L., \& Rothbauer, I.M. (2004, Eds.), Územní prognóza území dotčeného těžbou hnědého uhlí na Sokolovsku - Návrh (pp. 40-52). Retrieved from www.medard-lake.eu/ file_download/78

Šolc, P. (2008a, May 13). Možnosti vytváření společného trhu s elektřinou mezi Českou a Slovenskou republikou. Hospodář́ské noviny. Retrieved from http://www.datex.cz/clanek_080513_4.htm

Šrámek, P. (2009, January 15). Ministerstvo životního prostředí překvapivě nežádá vyškrtnutí jádra z energetické koncepce. ČT24. Retrieved from http://www.ct24.cz/ekonomika/41757-ministerstvo-zivotniho-prostredi-prekvapive-nezada-vyskrtnuti-jadra-z-energeticke-koncepce/ 
Štěrba, M. (2006). Simulační model energetické soustavy ČR. Retrieved from http://proatom.luksoft.cz/ view.php?cisloclanku=2006071001

Tajné nahrávky: Jak chtěl Drobiluv poradce černé peníze. (2010, December 15). Aktualne.cz. Retrieved from http://aktualne.centrum.cz/domaci/kauzy/clanek.phtml?id=685723

Temelín - termín dostavby neznámý. (1998, February 9). Ekolist. Retrieved from http://ekolist.cz/cz/zpravodajstvi/zpravy/temelin-termin-dostavby-neznamy

Teplárenské sdružení České republiky (n.d.a). Podíly paliv pro výrobu tepelné energie v krajích v roce 2009. Retrieved from http://www.tscr.cz/index.php?ta=115\&pg=0355

Teplárenské sdružení České republiky. (n.d.b). Soustava zásobování teplem. Retrieved from http://www. tscr.cz/schema/?ids $=10 \& \mathrm{~h}=550 \& \mathrm{x}=611060$

Teplárenské sdružení nadále odmitá cenové požadavky Czech Coalu. (2011, December 14). Allforpower. Retrieved from http://www.allforpower.cz/clanek/teplarenske-sdruzeni-nadale-odmita-cenove-pozadavky-czech-coalu/

Teplárenství-Obchod a trh (n.d.). Retrieved from http://www.mojeenergie.cz/cz/teplarenstvi-obchod-a-trh Teplárny si v Bruselu stěžuji na předražené uhli od Czech Coalu. (2012, March 6). Hospodářské noviny. Retrieved from http://hn.ihned.cz/c1-54934200-teplarny-si-v-bruselu-stezuji-na-predrazene-uhli-od-czech-coalu

Tezner, K. (n.d.a). Emisní povolenky jako vážný problém energetiky v ČR: vláda schválila derogace teplárny budou schopny investovat do ekologie. Retrieved from http://energostat.cz/emisni-povolenky-jako-vazny-problem-energetiky-v-cr.html

Tezner, K. (n.d.b). Těžební společnost Czech Coal na prahu odbytové krize: Czech Coal zatím na obdobi po roce 2012 prodal jen minimum uhli. Retrieved from http://energostat.cz/tezebni-spolecnost-czech-coal-na-prahu-odbytove-krize.html

Těžebni limity nesmíme nechat prolomit. (n.d.). Retrieved from http://www.veciverejne.cz/veci-verejne/ clanky/tezebni-limity-nesmime-nechat-prolomit.html

The Commission proposes $€ 5$ billion new investment in energy and Internet broadband infrastructure in 2009-2010, in support of the EU recovery plan. (2009, January 28). Retrieved from http://europa.eu/rapid/ pressReleasesAction.do?reference $=\mathrm{IP} / 09 / 142$

The EU ETS, a system based on the „,cap and trade“ principle. (n.d.). Retrieved from http://ec.europa.eu/ environment/climat/emission/index_en.htm

The European Network of Transmission System Operators for Electricity. Retrieved from https://www. entsoe.eu/

The European Nuclear Safety Regulators Group. Retrieved from http://www.ensreg.org/

The Leipzig Declaration on Global Climate Change. (1995, November). Retrieved from http://sovereignty.net/p/clim/leipzig97.htm

The Transalpine Pipeline. Retrieved from http://www.tal-oil.com/

The Ux Consulting Company, LLC. Retrieved from http://www.uxc.com/

The World Bank. Retrieved from http://www.worldbank.org/ 
Tomek, P. (2000). Československý uran 1945 - 1989. Těžba a prodej československého uranu v éře komunismu. Retrieved from http://aplikace.mvcr.cz/archiv2008/policie/udv/sesity/sesit1/sesit1.doc

Topolánek: Jižní koridor by měl být moderní obdobou „,hedvábné stezky“. (2011, August 16). Retrieved from http://www.eu2009.cz/cz/news-and-documents/press-releases/topolanek-jizni-koridor-by-mel-bytmoderni-obdobou-_hedvabne-stezky_-21594/index.html

Tramba, D. (2011, July 7). Moravu protne nový plynovod, spojí zemi s Nabuccem. Lidovky.cz. Retrieved from http://byznys.lidovky.cz/

Třanovický zásobník plynu zvýší energetickou bezpečnost Česka. (2010, May 27). ČT24. Retrieved from http://www.ct24.cz/

Třetí liberalizační balíček v energetice. (2009, July 21). EurActiv.cz. Retrieved from http://www.euractiv. cz/energetika/link-dossier/liberalizace-unijni-energetiky-000055

Tvarůžková, L. (2008, March 27). Ransdorf, nový spojenec ČEZ. Hospodářské noviny. Retrieved from http://hn.ihned.cz/c1-23592740-ransdorf-novy-spojenec-cez

U.S. Energy Information Administration. (2010). Country Analysis Briefs - Russia. Retrieved from http:// www.eia.gov/

Údaje o Temelínu. (n.d.). Econnect. Retrieved from http://www.ecn.cz/ENV/Temelin/UVOD.HTM

Uhlazený akumulátor Daniel Křetínský. (2012, January 19). Ekonom. Retrieved from http://ekonom.ihned.cz/index.php?p=400000_d\&\&article[id] $=54461240$

Unie uvažuje o zachováni dotací na těžbu uhlído roku 2018. (2010, December 9). Euraktiv. Retrieved from http:// www.euractiv.cz/energetika/clanek/unie-uvazuje-o-zachovani-dotaci-na-tezbu-uhli-do-roku-2018-008209

Unipetrol, a. s. Retrieved from http://www.unipetrol.cz/

Unipetrol, a. s. (2010a). 2009 v čislech - Stabilni partner v nestabilním prostředí. Retrieved from http:// www.unipetrol.cz/miranda2/export/sites/intranet/cs/sys/galerie-download/2009_v_cislech_1.pdf

Unipetrol, a. s. (2010b). Výroční zpráva 2009. Retrieved from http://www.unipetrol.cz/cs/index.html

United Nations Statistics Division. (2010). Carbon dioxide emissions (CO2), thousand metric tons of CO2 (CDIAC. Retrieved from http://mdgs.un.org/unsd/mdg/SeriesDetail.aspx?srid=749\&crid=

Úplné znění zákona č. 235/2004 Sb., o dani z přidané hodnoty, jak vyplývá z pozdějšich změn. Retrieved from www.mvcr.cz/soubor/sb012-10-pdf.aspx

UraniumMiner. Retrieved from http://www.uraniumminer.net/

Úřad vlády ČR, \& Nezávislá energetická komise. (2008, September 30). Zpráva Nezávislé odborné komise pro posouzení energetických potreb České republiky v dlouhodobém časovém horizontu. Retrieved from http://www.vlada.cz/assets/ppov/nezavisla-energeticka-komise/aktuality/zpravanek081122.pdf

Úřad vlády ČR, \& Oponentní rada. (2008, October 31). Oponentni posudek ke Zprávě Nezávislé odborné komise pro posouzeni energetických potřeb České republiky v dlouhodobém časovém horizontu. Retrieved from http://www.vlada.cz/assets/ppov/nezavisla-energeticka-komise/aktuality/Posudek-oponentni-rady.pdf

Úřad pro technickou normalizaci, metrologii a státní zkušebnictví. Retrieved from http://www.unmz.cz/ 
Usneseni Vlády České republiky ze dne 19. ř́jna 2009 č. 1300 ke Zprávě o prípravenosti České republiky na možnou dalši plynovou krizi. Retrieved from http://www.google.cz/url?sa=t\&source $=$ web $\& \mathrm{ct}=$ res $\& \mathrm{~cd}=2 \&$ ved $=0 \mathrm{CBs} Q \mathrm{FjAB} \&$ url $=\mathrm{http} \% 3 \mathrm{~A} \% 2 \mathrm{~F} \% 2 \mathrm{Fracek}$.vlada.cz $\% 2 \mathrm{Fus}-$ neseni \%2Fusneseni_webtest.nsf \%2Fweb_file \%2Fuv091019.1300.doc \%2F \%24File \%2Fuv091019.13 00.doc\&ei=U0QCTJiuA4mWOLrNtdYE\&usg=AFQjCNHVkTLyeMvzBYbg9qU-jP5BPmBz6A

UVR Mnišsek pod Brdy, a. s. Retrieved from http://www.uvr.cz/

V Rožné vznikne největší evropský podzemní zásobník na plyn. (2010, August 3). Finanční noviny. Retrieved from http://www.financninoviny.cz/

Veleba, L. (2007). Podzemní zásobníky plynu skupiny RWE v České republice: Současnost a budoucnost. Prezentace při př́ležitosti Podzimní plynárenské konference 2007. Retrieved from http://www.cgoa.cz/cs/ download/2007-presentace-lubor-veleba.pdf

VEMEX, s. r. o. Retrieved from http://www.vemex.cz/

Veselovský, M. (2008, March 13). Václav Bartuška - velvyslanec České republiky pro energetickou bezpečnost. [Záznam rozhovoru Radiožurnálu Český rozhlas 1]. Retrieved from http://www.rozhlas.cz/radiozurnal/publicistika/_zprava/434047

Vinšová, H. (2009, July 21). Solární park Velká nad Veličkou už dodává do sítě. Hospodářské noviny. Retrieved from http://stavitel.ihned.cz/

Vláda České republiky. (1991). Usneseni vlády České republiky ze dne 30. řijna 1991 č. 444 ke zprávě o územních ekologických limitech těžby hnědého uhli a energetiky $v$ Severočeské hnědouhelné pánvi. Retrieved from http://kormoran.vlada.cz/usneseni/usneseni_webtest.nsf/WebGovRes/7DCED4838DD30F36C12571B6006B9ABD?OpenDocument

Vláda České republiky. (2006, September 27). Programové prohlášeni vlády 2006. Retrieved from http:// www.vlada.cz/assets/clenove-vlady/historie-minulych-vlad/prehled-vlad-cr/1993-2007-cr/mirek-topolanek-1/Programove-prohlaseni-vlady.pdf

Vláda České republiky. (2007, January 17). Programové prohlášení vlády 2007. Retrieved from http:// www.vlada.cz/assets/clenove-vlady/historie-minulych-vlad/prehled-vlad-cr/1993-2007-cr/mirek-topolanek-2/Programove-prohlaseni-vlady_1.pdf

Vláda České republiky. (2009a). Pracovni program českého předsednictví, Evropa bez bariér 1. ledna - 30. června 2009. Retrieved from http://www.eu2009.cz/assets/news-and-documents/news/cz-pres_programme_cs.pdf

Vláda České republiky. (2009b). Výsledky českého předsednictví v Radě EU-Evropa bez bariér 1.1.2009 - 30.6.2009. Retrieved from http://www.eu2009.cz/assets/czech-presidency/programme-and-priorities/ achievements/cz-pres_vysledky_cs_2.pdf

Vláda České republiky. (2010a, August 4). Programové prohlášení vlády. Retrieved from http://www. vlada.cz/

Vláda České republiky. (2010b). Programové prohlášeni vlády 2010. Retrieved from http://www.vlada.cz/ assets/media-centrum/dulezite-dokumenty/Programove_prohlaseni_vlady.pdf

Vláda schválila energetickou koncepci se změnami v těžbě uhlí. (2004, March 10). Hospodářské noviny. Retrieved from http://byznys.ihned.cz/c1-14084690 
Vlček, T. \& Černoch, F. (2013). Aktuální témata a projekty v oblasti skladování a dopravy ropy do ČR. Paliva, 5(1), pp. 1-6. Retrieved from http://paliva.vscht.cz/

Vodní elektrárny v $\check{C} R$. Retrieved from http://www.vodni-tepelne-elektrarny.cz/vodni-elektrarny-cr.htm

Vrána, V., \& Kolář, V. (2000). Dimenzování a jištění elektrických vedení. Studijní text Fakulty strojní Katedry obecné elektrotechniky VŠB-TU Ostrava. Retrieved from http://feil.vsb.cz/kat420/vyuka/Bakalarske_FS/prednasky/sylab_dimenz_bc \%20FS.pdf

Vyhláška ERÚ č. 673 ze dne 21. prosince 2004, kterou se stanoví pravidla pro organizování trhu s plynem, dostupné on-line (http://www.energetik.cz/hlavni3.html?m1=/zakony/673_2004.html).

Vyhláška ERÚ č. 140/2009 Sb. ze dne 11. května 2009 o způsobu regulace cen v energetických odvětvích a postupech pro regulaci cen. Retrieved from http://www.eru.cz/user_data/files/legislativa/legislativa CR/navrh \%20vyhlasek/Vyhlaska_140_16_06_2010.pdf

Vyhláška ze dne 17. července 2007, kterou se stanoví podrobnosti účinnosti užití energie při rozvodu tepelné energie a vnitřním rozvodu tepelné energie a chladu. Retrieved from http://portal.gov.cz/zakon/193/2007

Výlupek, L. (2003, May 7). Elektroenergetika a plynárenství v ČR. Hospodářské noviny. Retrieved from http://hn.ihned.cz/c1-12751870-elektroenergetika-a-plynarenstvi-v

Výpadky ropovodu Družba pojistí ropovod z Německa. (2010, November 23). BusinnessInfo.cz. Retrieved from http://www.businessinfo.cz/cz/

Výzkumný ústav pro hnědé uhlí, a. s. Retrieved from http://www.vuhu.cz/

Waisová, Ц̌s. (2008). Úvodem. Energetická bezpečnost v evropském prostoru: současný stav a střednědobé perspektivy. In Waisová, Š. (Ed.), Evropská energetická bezpečnost (pp. 9-40). Plzeň: Aleš Čeněk, s. r. o.

Zajíček, M. (1999). Liberalizace elektroenergetického trhu v České republice. Czech Business and Trade,1999(3). Retrieved from http://elektrina.ecn.cz/dokumenty/liberalizace.html

Zákon 222/1994 ze dne 2. listopadu 1994 o podmínkách podnikání a o výkonu státní správy v energetických odvětvích a o Státní energetické inspekci. Retrieved from http://www.lexdata.cz/web/sb_free. nsf/c12571d20046a0b2c12566af007f1a09/c12571d20046a0b2c12566d400743622?OpenDocument

Zákon 406/2000 ze dne 25. ř́inna 2000 o hospodaření energií. Retrieved from http://portal.gov.cz/wps/ WPS_PA_2001/jsp/download.jsp?s=1\&l=406\%2F2000

Zákon 458/2000 ze dne ze dne 28. listopadu 2000 o podmínkách podnikání a o výkonu státní správy v energetických odvětvích a o změně některých zákonů (energetický zákon). Retrieved from http://portal.gov. cz/wps/WPS_PA_2001/jsp/download.jsp?s=1\&l=458\%2F2000

Zákon 79/1957 ze dne 19. prosince 1957 o výrobě, rozvodu a spotřebě elektřiny (elektrisační zákon). Retrieved from http://www.lexdata.cz/lexdata/sb_free.nsf/c12571cc00341df10000000000000000/ c12571cc00341df1c12566d40071d0ae?OpenDocument

Zákon č. 44/1988 Sb., o ochraně a využití nerostného bohatství (horní zákon) jehož úplné znění bylo uveřejněno v zákoně č. 439/1992 Sb., ve znění pozdějších změn provedených zákonem č. 10/1993 Sb., zákonem č. 168/1993 Sb., zákonem č. 366/2000 Sb., zákonem č. 132/2000 Sb., zákonem č. 258/2000 Sb., zákonem č. 315/2001 Sb., zákonem č. 61/2002 Sb., zákonem č. 320/2002 Sb., zákonem č. 150/2003 Sb., zákonem č. 3/2005 Sb., zákonem č. 386/2005 Sb. a zákonem č. 313/2006 Sb. Retrieved from ttp://www. cbusbs.cz/docs/zakon1988-044.doc 
Zákon č. 526/1990 Sb. ze dne 27. listopadu 1990 o cenách. Retrieved from http://www.mfcr.cz/cps/rde/ xchg/mfcr/xsl/cenova_politika_19240.html

Zákon č. 17/1992 Sb., o životním prostředí, ve znění pozdějších předpisů. Retrieved from http://www. mzp.cz/www/platnalegislativa.nsf/d79c09c54250df0dc1256e8900296e32/5b17dd457274213ec12572f3002827de?OpenDocument

Zákon č. 158/2001 Sb., o odpadech a o změně některých dalších zákonü. Retrieved from http://www. mzp.cz/www/platnalegislativa.nsf/d79c09c54250df0dc1256e8900296e32/8FC3E5C15334AB9DC125727B00339581/\$file/185-01 \%20- \%20odpady.pdf

Zákon č. 180/2005 Sb., o podpoře výroby elektřiny z obnovitelných zdrojů energie a o změně některých zákonů (zákon o podpoře využívání obnovitelných zdrojů). Retrieved from http://www.tzb-info.cz/ pravni-predpisy/zakon-c-180-2005-sb-o-podpore-vyroby-elektriny-z-obnovitelnych-zdroju-energie-a-ozmene-nekterych-zakonu-zakon-o-podpore-vyuzivani-obnovitelnych-zdroju

Zákon č. 261/2007 Sb. o stabilizaci veřejných rozpočtů. Retrieved from http://portal.gov.cz/wps/portal/_s $.155 / 701$ ?kam=zakon\&c=261/2007

Zákon č. 157/2009 Sb., o nakládání s těžebním odpadem a o změně některých zákonů. Retrieved from http://www.cbusbs.cz/docs/zakon2009-157.doc

Zákon č. 146/2010 Sb., o označování a sledovatelnosti výbušnin pro civilní použití. Retrieved from http:// www.sbirka.cz/POSL4TYD/NOVE/10-146.htm

Zákon č. 370/2011 Sb. ze dne 6. listopadu 2011, kterým se mění zákon č. 235/2004 Sb., o dani z přidané hodnoty, ve znění pozdějších předpisů, a další související zákony. Retrieved from aplikace.mvcr.cz/sbirka-zakonu/ViewFile.aspx?type $=$ z\&id=23466

Zákon ČNR č. 61/1988 Sb., o hornické činnosti, výbušninách a o státní báňské správě, ve znění zákona ČNR č. 425/1990 Sb., zákona ČNR č. 542/1991 Sb., zákona č. 169/1993 Sb., zákona č. 128/1999 Sb., zákona č. 71/2000 Sb., zákona č. 124/2000 Sb., zákona č. 315/2001 Sb., zákona č. 206/2002 Sb., zákona č. 320/2002 Sb., [úplné znění č. 408/2002 Sb.], zákona č. 150/2003 Sb., zákona č. 226/2003 Sb., zákona č. 227/2003 Sb., zákona č. 3/2005 Sb., zákona č. 386/2005 Sb., zákona č. 186/2006 Sb., zákona č. 313/2006 Sb., zákona č. 342/2006 Sb, zákona č. 296/2007 Sb., zákona č. 376/2007 Sb., zákona č. 124/2008 Sb., zákona č. 189/2008 Sb. a zákona č. 274/2008 Sb., zákona č. 223/2009 Sb., zákona č. 227/2009 Sb., zákona č. 281/2009 Sb. a zákona č. 155/2010 Sb. Retrieved from http://www.cbusbs.cz/docs/zakon1988-061.doc

Zákon ČNR č. 552/1991 Sb. ze dne 6. prosince 1991 o státní kontrole. Retrieved from http://aplikace. mvcr.cz/archiv2008/sbirka/1991/sb104-91.pdf

Zákon ze dne 24. ledna 1997 o mírovém využívání jaderné energie a ionizujícího záření (atomový zákon) a o změně a doplnění některých zákonů. Retrieved from http://www.epravo.cz/top/zakony/sbirka-zakonu/ zakon-o-mirovem-vyuzivani-jaderne-energie-a-ionizujiciho-zareni-atomovy-zakon-a-o-zmene-a-doplneni-nekterych-zakonu-13694.html

Zákon ze dne 31. ledna 2012 o podporovaných zdrojích energie a o změně některých zákonů. Retrieved from http://ftp.aspi.cz/opispdf/2012/059-2012.pdf

Zaměstnavatelskýs svaz důlního a naftového průmyslu Společenstvo těžař̃u ČR. Retrieved from http://www. zsdnp.cz/

Zámyslický, P. (2009). Politika ochrany klimatu v České republice. Časopis Ochrana př́rody, 2009(zvláštní číslo). Retrieved from http://www.casopis.ochranaprirody.cz/ 
Zaplatílek, J. (2007). Zásobování České republiky ropou. Pro-Energy magazín, 2007(2), pp. 68-71. Retrieved from http://www.pro-energy.cz/clanky2/4.pdf

Zaplatílek, J. (2008). Bezpečnost a spolehlivost dodávek zemního plynu, ropy a ropných produktio. Retrieved from www.aem.cz/svse/ae080327/mpo_zaplatilek.ppt

Zaplatílek, J. (2009). České plynárenství prošlo náročnou zkouškou úspěšně. Pro-Energy magazín, 2009 (1), pp. 40-43. Retrieved from http://pro-energy.cz/clanky9/2.pdf

Zásobník plynu odmítli. Přesto začne průzkum. (2010, January 26). MF Dnes. Retrieved from http://ekolist.cz/

Závěrečná zpráva expertního týmu pro nezávislé posouzeni projektu dostavby Jaderné elektrárny Temelín. (1999, February 28). Retrieved from http://new.ecn.cz/doc/old/Enviro/energetika/Texts/zprava_komise.htm

Závěry odsouhlasené účastniky opinion poolu odborné diskuse Energetická bezpečnost ČR: představy vs. mýty vs. Realita. (2010, April 27). Praha. Retrieved from http://ivd.cz/cs/energeticka_bezpecnost_cr/ energeticka_bezpecnost_cr_predstavy_vs_myty_vs_realita?tab=zavery

Záznam 12. společné schůze Sněmovny lidu a Sněmovny národi̊ Federálního shromážděni ČSSR konané ve dnech 21. a 22. března 1984, 2. den - Čtvrtek 22. března 1984. Retrieved from http://www.psp.cz/ eknih/1981fs/slsn/stenprot/012schuz/s012017.htm

Záznam 66. schůze Národního shromáždění československého z úterý 22. července 1919. Retrieved from http://www.psp.cz/eknih/1918ns/ps/stenprot/066schuz/s066003.htm

Záznam 66. schůze Národního shromáždění československého z úterý 22. července 1919. Retrieved from http://www.psp.cz/eknih/1918ns/ps/stenprot/066schuz/s066003.htm

Zbyňek Boldiš: Blackout je pouze otázkou času. (2009, April 7). Euraktiv. Retrieved from http://www. euractiv.cz/energetika/interview/zbynek-boldis-blackout-je-pouze-otazkou-casu-005844

Zelenka, R. (2009, December 2). Pojistka pro Česko: Nové zásobníky plynu. E15.cz. Retrieved from http://www.e15.cz/byznys/prumysl-a-energetika/pojistka-pro-cesko-nove-zasobniky-plynu

Zespół Elektrowni Pątnów - Adamów - Konin SA. (2011, March 25). Rafako odpadło, Enea startuje, Dzienink Gazeta Prawna. Retrieved from http://www.zepak.com.pl/pl/prasa_zepaksa/zepak_2011/pak_ enea_rafako

Zpráva Nezávislé odborné komise pro posouzení energetických potreb České republiky v dlouhodobém časovém horizontu. (2008, September 30). Retrieved from http://www.vlada.cz/assets/media-centrum/aktualne/Pracovni-verze-k-oponenture.pdf

Žižka, J. (2009, November 16). Plynovod Moravia propojí Česko a Polsko. E15.cz. Retrieved from http:// www.e15.cz/byznys/prumysl-a-energetika/plynovod-moravia-propoji-cesko-a-polsko

Žižka, J. (2010, August 2). Česko zvažuje třetí ropovod. E15. Retrieved from http://www.e15.cz/

Žižka, J. (2012, September 23). Kredity: ČEZ vítězí, ostatní přežili. E15. Retrieved from http://www.e15.cz/

Žižka, J. (2013, April 2). Osud českých plynovodů: Dříve, nebo později budou zase na prodej. Česká pozice. Retrieved from http://www.ceskapozice.cz/ 


\section{Nominal Index}

Ambrozek Libor, 30, 31, 32

Babis Andrej, 38

Bakala Zdenek, 12, 16, 42

Baran Vaclav, 144

Bartuska Vaclav, 103, 139, 168

Benes Daniel, 80, 84

Bizkova Rut, 25, 26, 33

Blazek Ladislav, 64, 145

Bobel Vasil, 43, 80

Brezina Petr, 12

Bruderle Rainer, 180

Bubenik Josef, 32

Bursik Martin, 24, 25, 26, 32, 33

Cenek Roman, 44

Cerny Jiri, 14

Dejmal Ivan, 58

Demanesse Jean-Luc, 41

Dienstl Jan, 64, 80, 81, 83

Dlouhy Pavel, 24

Dlouhy Vladimir, 28, 32, 105

Dolezal Ales, 32

Dolezal Zdenek, 39

Drobil Pavel, 25, 26

Dusik Jan, 25, 26, 33

Fico Robert, 97

Firt Josef, 27

Fischer Jan, 22, 23, 25, 33

Fohler Tomas, 80

Graf Ales, 12

Gregr Miroslav, 28, 36, 40, 51

Gross Stanislav, 44

Grulich Vaclav, 51

Harald V, 105

Hrdlicka Frantisek, 32

Huner Tomas, 102, 141, 158

Chalupa Tomas, 25, 26
Jahnatek Lubomir, 97

Jise Jiri, 12

Johanes Vladimir, 59

Kacena Michal, 54

Kalas Petr Jan, 22, 24

Kalda Karel, 42

Karas Petr, 54

Kaspar Jakub, 33

Kavina Pavel, 160

Kellner Petr, 80

Klaus Vaclav, 105, 157

Kocourek Martin, 23, 33, 142, 179

Kolacek Antonin, 43, 44

Kolacek Viktor, 42, 43, 44

Komarek Karel, 87

Komarek Michal, 26

Kopacka Ludvik, 137

Kretinsky Daniel, 13, 80, 81, 83, 85

Kriz Ladislav, 55

Krouzecky Jan, 16, 64

Krusina Jiri, 14

Kuba Martin, 24, 34, 145

Kubin Miroslav, 32, 168

Kuhnl Karel, 28, 43

Kuhnt Dietmar, 41

Kuchtova Dana, 32

Lamich Petr, 14

Martinek Jiri, 44

Mekota Lubos, 43, 44

Miklas Pavel, 14

Miko Ladislav, 25, 26

Mil Jaroslav, 45

Mitterlehner Reinhold, 97

Musela Pavel, 44

Necas Petr, 22, 23, 25, 26, 43, 137, 142

Novacek Alexej, 84

Otava Petr, 42, 43, 44

Otcenasek Petr, 32, 181 
Paces Vaclav, 30, 31, 32, 33, 71, 75, 137, 141, 154, 160

Paroubek Jiri, 39

Paukner Petr, 12

Pecina Martin, 30, 31, 44

Petrzilek Petr, 32, 33

Piha Miroslav, 167

Pilip Ivan, 43

Pisarikova Hana, 12

Pithart Petr, 49

Przybyl Jan, 43

Pudil Petr, 43, 80

Riman Martin, 22, 23, 31, 32

Rokos Jaroslav, 16, 64

Roman Martin, 44, 45, 80, 81, 141, 144

Ruzicka Milan, 12

Ruzicka Milos, 42, 43

Sack Rainer, 13

Sedlak Martin, 143

Sequens Edvard, 32

Slivka Vladimir, 73, 75, 76

Spicar Radek, 26

Spyra Jacek, 39

Stepanek Frantisek, 16, 64

Sulova Karolina, 31
Tesar Jaromir, 14

Tkac Patrik, 80

Topolanek Mirek, 22, 31, 33, 58, 59, 84

Tosovsky Josef, 49

Tosovsky Vladimir, 23, 33, 117

Tykac Pavel, 44, 64, 80

Urban Milan, 30, 31, 33, 41, 59

Veleba Jan, 112, 159

Vitaskova Alena, 27

Vlk Vladimir, 32, 161

Vondra Alexandr, 103

Vorlicka Zdenek, 39

Zajicek Miroslav, 40, 74, 156

Zak Tomas, 137

Zeman Jan, 156

Zeman Karel, 74

Zeman Milos, 40, 51

Zoubek Jiri, 16 


\title{
Tomáš Vlček, Filip Černoch \\ THE ENERGY SECTOR AND ENERGY POLICY OF THE CZECH REPUBLIC
}

\author{
Typography by GRAFEX-AGENCY s.r.o. \\ English proofreading by Simon Hooper \\ Cover image from free photo stock sxc.hu \\ Published by Masaryk University \\ Žerotínovo nám. 617/9, 60177 Brno, www.muni.cz \\ 1st edition, 2013 \\ www.mves.cz \\ www.opvk.fss.muni.cz/ensec/
}

ISBN 978-80-210-6523-9

DOI: 10.5817/CZ.MUNI.M210-6523-2013 
The project "Innovation of lecturing at FSS - the Department of International Relations and European Studies" ( $C Z$ 1.07/2.2.00/15.0221) responds to the requirements of the labour market and the need to prepare students for employment related to the energy sector and energy security in a comprehensive manner. It enables students to gain knowledge applicable in practice and to benefit from the cooperation with the most progressive companies in the field. The project encompasses 9 new and innovative courses; internships with a special focus on practice, excursions and round tables in cooperation with ČEPS, a.s., ČEZ, a.S., Jihomoravská plynárenská, a.s. and the Museum of Oil Mining and Geology; lectures given by external experts from the USA, the Great Britain, Poland, Germany and other countries. The project has been co-financed from the European Social Fund and the state budget of the Czech Republic. 